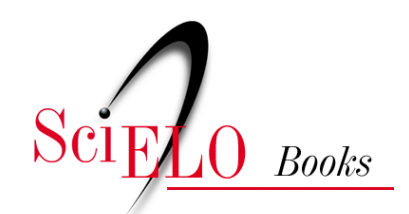

Editora da UESC

\title{
Ordem imperial e aldeamento indígena \\ Camacãns, Gueréns e Pataxós do Sul da Bahia
}

\author{
Ayalla Oliveira Silva
}

SILVA, A.O. Ordem imperial e aldeamento indígena: Camacãns, Gueréns e Pataxós do Sul da Bahia [online]. Ilhéus: Editus, 2018, 319 p. ISBN: 978-85-7455-528-7.

https://doi.org/10.7476/9788574555287.

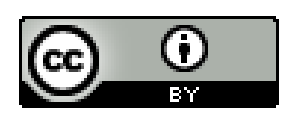

All the contents of this work, except where otherwise noted, is licensed under a Creative Commons Attribution $\underline{4.0 \text { International license. }}$

Todo o conteúdo deste trabalho, exceto quando houver ressalva, é publicado sob a licença Creative Commons Atribição 4.0.

Todo el contenido de esta obra, excepto donde se indique lo contrario, está bajo licencia de la licencia Creative Commons Reconocimento 4.0. 


\section{ORDEM IMPERIAL E ALDEAMENTO INDÍGENA}

CAMACÃS, GUERÉNS E PATAXÓS NO SUL DA BAHIA 


\section{Universidade Estadual de Santa Cruz}

GOVERNO DO ESTADO DA BAHIA

Rui Costa - Governador

SECRETARIA DE EDUCAÇÃO

Walter Pinheiro - Secretário

UNIVERSIDADE ESTADUAL DE SANTA CRUZ

Adélia Maria Carvalho de Melo Pinheiro - Reitora

Evandro Sena Freire - Vice-Reitor

\section{DIRETORA DA EDITUS}

Rita Virginia Alves Santos Argollo

\section{Conselho Editorial}

Rita Virginia Alves Santos Argollo - Presidente

Evandro Sena Freire

José Montival Alencar Junior

André Luiz Rosa Ribeiro

Andrea de Azevedo Morégula

Adriana dos Santos Reis Lemos

Dorival de Freitas

Guilhardes de Jesus Júnior

Lucia Fernanda Pinheiro Barros

Lurdes Bertol Rocha

Nelson Dinamarco Ludovico

Rita Jaqueline Nogueira Chiapetti

Samuel Leandro Oliveira de Mattos

Silvia Maria Santos Carvalho 


\section{Ayalla Oliveira Silva}

\section{ORDEM IMPERIAL E ALDEAMENTO INDÍGENA}

CAMACÃS, GUERÉNS E PATAXÓS NO SUL DA BAHIA

Ilhéus - Bahia

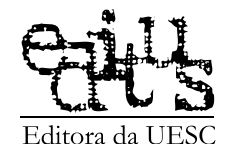

2018 
Direitos desta edição reservados à EDITUS - EDITORA DA UESC

A reprodução não autorizada desta publicação, por qualquer meio, seja total ou parcial, constitui violação da Lei no 9.610/98.

Depósito legal na Biblioteca Nacional, conforme Lei no 10.994 , de 14 de dezembro de 2004.

\title{
PROJETO GRÁFICO, CAPA E DIAGRAMAÇÃO
}

Álvaro Coelho

Lária Farias Batista

\section{REVISÁO}

Roberto Santos de Carvalho

Maria Luiza Nora

\section{IMAGENS DA CAPA}

"Ferada, Dom Pedro di Alcantara", por Joseph Selleny, 1860.

Disponível em: https://www.onb.ac.at/en/

Mapa elaborado pelo capitấo I. V. Pederneiras e Tenente. M. R. da Costa e cedido pelo Arquivo

Histórico do Exército (AHEX)-RJ. Fotografia: Fábio Marques Aragão

Dados Internacionais de Catalogação na Publicação (CIP)

S586 Silva, Ayalla Oliveira
Ordem imperial e aldeamento indígena: Camacãs, Guerens e Pataxós no
Sul da Bahia / Ayalla Oliveira Silva. - Ilhéus, BA: Editus, 2018.
319 p.: il.
Referências: p. 309-319.
ISBN: 978-85-7455-470-9
1. Aldeias indígenas - Bahia. 2. Índios - Historiografia. 3. Índios
- Aspectos sociais. 4. Índios - Brasil - História - Período colonial -
1500-1822. 5. Índios - Brasil - História - Império - 1822-1889. I.
Título.
CDD 980.41

\section{EDITUS - EDITORA DA UESC}

Universidade Estadual de Santa Cruz

Rodovia Jorge Amado, km 16 - 45662-90o - Ilhéus, Bahia, Brasil

\author{
Tel.: (73) 3680-5028 \\ www.uesc.br/editora \\ editus@uesc.br
}

EDITORA FILIADA À

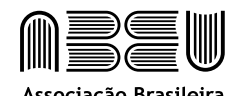

Associação Brasileira 
À memória de Braulino Lopes Silva, meu pai, que ensinou-me o valor de sonhar. 


\section{APRESENTAÇÁO}

ORDEM IMPERIAL E ALDEAMENTO INDÍGENA: Camacãs, Gueréns e Pataxós no Sul da Bahia é uma pesquisa histórica de fôlego, baseada em rica documentação primária e em um diálogo firme com várias questões importantes levantadas pela historiografia contemporânea. O foco do olhar e da pesquisa de Ayalla Oliveira Silva se dirige aos povos do sul da Bahia: camacãs, pataxós, guerens e inúmeros outros grupos indígenas que, depois de aldeados e ressocializados no mundo colonial e imperial, passaram a ser reconhecidos como índios, índios aldeados ou ainda índios de Ferradas.

A autora não poupou esforços para expor, analisar e problematizar seu tema de pesquisa, desenvolvendo-o em cinco capítulos densos e bem estruturados. Com erudição, começa a reflexão se debruçando sobre os memorialistas que escreveram a história de Itabuna. Demonstra que lembrar e esquecer são típicos da memória e que tais operações não são aleatórias. Lembrase e esquece-se ao sabor de conjunturas históricas específicas e em função de necessidades e projetos políticos e sociais. De acordo com ela: "A leitura feita sobre as populações indígenas do sul da Bahia na escrita memorialista era extremamente pejorativa. Os índios eram descritos como os selvagens que percebendo a inutilidade de suas flechas diante das armas de fogo dos colonizadores, se aprofundavam nas matas." 
Waly Salomão disse, com simplicidade e profundidade poética, que "a memória é uma ilha de edição". ${ }^{1}$ Quando se trata de memória pessoal, a questão é, naturalmente, de foro íntimo. O mesmo não se pode dizer da memória social que afeta a todos: incluídos e excluídos dela. Tratar povos, comunidades e indivíduos indígenas como "selvagens" e deixá-los fora da narrativa histórica não é, contudo, uma característica particular dos memorialistas do sul da Bahia. Como argumentou o saudoso historiador John Monteiro, desde a constituição do Instituto Histórico e Geográfico Brasileiro, em 1838, estabeleceu-se a firme convicção de que os índios eram objeto da etnografia, não da disciplina história, justamente por serem considerados povos "primitivos" e "selvagens". ${ }^{2}$ Além disso, vários profissionais e leigos começaram a acreditar que os índios estavam fora da historiografia por motivos bem concretos, notadamente a ausência de fontes históricas para estudálos. De modo ainda mais dramático, os índios estariam fora da narrativa histórica em razão do precoce e rápido desaparecimento físico deles do cenário social, após o contato com os colonizadores.

Ayalla Oliveira Silva não fechou os olhos para as evidências do tempo presente. No sul da Bahia, os conflitos de terra entre índios e não índios são renhidos e representam um vívido testemunho de que os índios fazem parte do presente, como antes fizeram parte do passado. Foi aos

1 “Meu nome é Waly Salomão/Um nome árabe, Waly Dias Salomão/Nasci numa pequena cidade na caatinga baiana/Do sertão baiano/Filho de pai árabe e uma sertaneja baiana/A memória é uma ilha de edição/Nasci sob um teto sossegado/Meu sonho era um pequeninho sonho meu/ [...]". In: O Rappa. O silêncio que precede o esporro. Warner Music, 2003.

2 Monteiro, John Manuel. Tupis, tapuias e historiadores: Estudos de história indígena e do indigenismo". Tese de Livre Docência, Universidade Estadual de Campinas, 2001. 
arquivos e constatou a existência de fontes em abundância sobre eles na longa duração da história regional. Os quatro capítulos seguintes deste livro demonstram que os velhos argumentos para excluir os índios da historiografia não resistem a uma boa pesquisa em arquivos. Neles, Ayalla discute como parte dos povos e comunidades indígenas da região foram assimilados à sociedade imperial, bem como o papel desempenhado pelo aldeamento indígena de São Pedro de Alcântara no processo de conquista territorial e de implantação da lavoura de cacau na região.

A exegese documental e bibliográfica realizada pela autora nos mostra que camacãs e guerens aldeados e camacãs, botocudos e pataxós não aldeados foram protagonistas de suas experiências históricas, a despeito das próprias limitações e desvantagens. As dificuldades dos índios eram, efetivamente, grandes, pois a região estava conflagrada pela guerra desencadeada contra os botocudos. Apesar disso, o sul da Bahia foi também palco de negociações entre índios, missionários, autoridades e colonos. Assim, mesmo açodados por guerras, fomes e perseguições, os índios não desistiram de fazer escolhas e de buscar caminhos para manter o comando de suas vidas. Nessa trajetória, além disso, muitos passaram por um profundo processo de reestruturação de suas próprias identidades e lealdades políticas, ingressando no mundo dos índios aldeados e assumindo novas formas de viver coletivamente.

Conhecido também como aldeamento de Ferradas, São Pedro de Alcântara foi criado, em 1814, para ressocializar os índios e colocá-los à serviço dos interesses do Estado e dos colonos que, progressivamente, chegavam à região. Dirigido por missionários capuchinhos e acompanhado de perto pelo ouvidor Balthazar da Silva Lisboa, em pouco tempo o aldeamento se tornou um dos maiores produtores de cacau do sul da Bahia, enriquecendo, ao que 
tudo indica, muito mais ao ouvidor do que aos índios. $\mathrm{O}$ trabalho indígena foi também importante fora dos limites do aldeamento, em atividades de interesse público, como construção de estradas e navegação de rios, e no cultivo de cacau nas terras dos colonos. Sem a inclusão dos índios na história regional, portanto, dificilmente se explicará de modo convincente a conquista do território e a implantação da economia cacaueira no sul da Bahia.

A intenção dessa apresentação não é antecipar a rica reflexão realizada pela autora nos diferentes capítulos de seu livro. Caberá ao leitor e à leitora percorrer as páginas desse livro e descobrir, por si mesmos, uma história nova sobre o sul da Bahia. Nova, em primeiro lugar, porque se dedica a povos, comunidades, grupos e indivíduos negligenciados e até mesmo deliberadamente esquecidos e hostilizados pelo modo tradicional de escrever a história nacional. Nova, porque trata de experiências e instituições sociais brasileiras e de relações interétnicas ainda pouco visitadas pela historiografia contemporânea. Nova, enfim, porque o estudo de Ayalla faz parte do que crescentemente tem sido qualificado, no meio historiográfico, como a nova história dos índios.

Rótulos historiográficos são sempre problemáticos e suscetíveis a muitas críticas. A despeito disso, é evidente que, a partir dos anos 1980 e 1990, deu-se um salto qualitativo e quantitativo nos estudos históricos e antropológicos sobre os índios no Brasil, movimento claramente influenciado pela publicação de livros seminais, como os de Manuela Carneiro da Cunha e de John Manuel Monteiro. ${ }^{3}$

3 CUNHA, Manuela Carneiro da (org.). História dos índios no Brasil. São Paulo: Companhia das Letras/Secretaria Municipal de Cultura/ Fapesp, 1992; MONTEIRO, John Manuel. Negros da terra: índios e bandeirantes nas origens de São Paulo. São Paulo: Companhia das Letras, 1994. 
Para mim, existem alguns traços importantes na historiografia contemporânea dedicada aos índios e ao indigenismo no Brasil e na América Latina e, dentre eles, alguns aparecem claramente no livro de Ayalla: crítica à exclusão dos índios da história; recusa em reduzir a história dos índios aos processos de extinção física e cultural, reconhecendo, contudo, as violências e opressões vividas por eles; diálogo firme com a antropologia para, dentre outras questões importantes, abordar o aparecimento e o desenvolvimento de novas identidades e culturas indígenas ao longo da história; e compromisso de incluir os índios nos contextos históricos regionais e nacionais mais amplos, salientando, sempre que possível, o protagonismo indígena nas experiências sociais e políticas vividas por eles. Ayalla é uma jovem historiadora que, ao agregar-se a esse movimento da historiografia, termina por servir de testemunho acerca de seu dinamismo e vigor.

Vânia Maria Losada Moreira Madri, 24 de junho de 2016. 


\section{AGRADECIMENTOS}

Os agradecimentos ocupam a última parte a ser escrita neste trabalho, uma versão um pouco modificada da minha dissertação de mestrado. A sensação é essa: cheguei ao fim, acabou! A alegria sentida não é porque o trabalho acabou, concluo apenas uma etapa, mas o trabalho continua e a paixão pelo que faço me move, ela é indescritível. O sentimento de alegria fica a cargo da concretização de um sonho, do qual muitas pessoas fizeram parte, de forma indireta e direta. Eu agradeço carinhosamente àquelas que me ajudaram a tornar possível a conclusão de mais uma etapa.

Ao programa de Pós-Graduação em História da UFRRJ, à professora Rebeca Gontijo, coordenadora do programa, e ao secretário Paulo Longarini, pela atenção e disponibilidade de sempre. Aos meus colegas da pósgraduação e aos professores, com quem muito aprendi nas disciplinas cursadas.

Aos funcionários do Arquivo Público do Estado da Bahia (APEB) que, nas minhas intensivas visitas, invariavelmente correndo contra o tempo, no afã de dar conta de uma documentação superior à que o tempo me permitia, compreensivamente me auxiliavam de forma muito gentil; em especial, agradeço a Pedro, Elza e Reinaldo. A Urano, o pesquisador que mais conhece aquele Arquivo e seus acervos. Salvou-me muitas vezes, me dando dicas e, inclusive, emprestando-me seu material de trabalho.

A Frei Ulisses Pinto, arquivista do Arquivo Histórico Nossa Senhora da Piedade, da Ordem dos Frades Menores Capuchinhos (OFMCap.), da Província da Bahia, agradeço 
pela recepção sempre alegre e prestativa, e também à sua secretária Vanice, pelos cafezinhos e pela companhia na sala de consulta.

Ao Centro de Documentação e Memória da UESC, na pessoa da amiga e grande profissional Stela Teixeira. O CEDOC é especial, foi lá que os primeiros passos foram dados. Além da consulta ao acervo hemerográfico, naquele espaço, eu tive muitas e produtivas conversas com o professor Marcelo Henrique Dias e com os queridos amigos da graduação: Angélica, Victor e João, amigos e parceiros de estudo.

Agradeço à Fundação Marimbeta, pelo apoio dado aos meus estudos desde a graduação. Aos amigos queridos de trabalho: dona Vera (uma mãezona), Carlos, Lucas, Jacque e Rai, incentivadores e colaboradores incondicionais, agradeço de forma muito especial.

Além dos amigos já mencionados, agradeço aos demais amigos antigos e aos novos: Norma, Graci, Michele, Adê, Angélica, Marcelo, Antônio, Natália e Maylin. A cada uma e cada um, de forma particular e especial. Agradeço à querida Ir. Emídia pelo cuidado e pelas orações a mim dedicadas. À Bruna e Everton, quero levar nossa amizade, construída nesses dois anos, para toda a vida. Com Everton dividi muitos momentos difíceis nos primeiros tempos no Rio, mas dividimos também muitas aventuras pela "Cidade Maravilhosa"; como ríamos de nossas distrações! Transformamo-nos em amigos-irmãos.

Meus agradecimentos à amiga Sarah, com carinho e saudade. Dividimos as dificuldades, os desafios e as alegrias do primeiro ano do mestrado. Agradeço à Talita, amiga de outros tempos, com quem tenho estreitado os laços e dividido as experiências diárias.

Agradeço às professoras Fabiane Popinigis e Maria Regina Celestino de Almeida e ao professor Marcelo Henrique Dias, por aceitarem o convite para participar da banca de defesa. 
Aos professores Anna Côgo e Marcelo Henrique Dias dedico meus agradecimentos de forma especial, pois me ensinaram os primeiros passos da pesquisa, com paciência, zelo e cuidado.

Ao professor Carlos José Ferreira, pelas contribuições e cessão do título do seu livro Nem tudo era italiano, fruto do trocadilho por ele feito entre os nossos trabalhos. Também à professora Mary Ann Mahony por me apresentar à Biblioteca Nacional da Áustria, cujo acervo guarda diversas obras acerca do sul da Bahia, em 1860, incluindo Ferradas.

À professora Vânia Moreira, minha orientadora, por quem tenho grande admiração, faltam palavras para agradecer. Sua paciência, generosidade, solicitude, confiança e erudição foram fundamentais, não apenas para o desenvolvimento deste trabalho, como ao meu próprio crescimento acadêmico, ao longo dos dois anos de mestrado. Foi por sua condução segura, generosa e tranquila que consegui chegar até aqui. Obrigada pela leitura criteriosa e rigorosa dos capítulos, sempre sensível às minhas dificuldades. Obrigada também pelo convívio afetuoso, pois, na nossa convivência sempre permearam os sentimentos de respeito, cuidado e carinho. À Vânia, dedico a minha gratidão.

Gratidão também à minha amada família, às minhas irmãs, Cida, Rene e Gil; meus irmãos, Sandrinho, Fabinho e Má; à minha mãe, Vera Lúcia; minha avó, Vicência (dona Chica); minhas tias e tios; às primas. A família é demasiado grande, por isso, não vou citar todos os nomes, salvo dos pequenos, Alexia, Artur e Pietro, os sobrinhos, de quem a distância tem me furtado a convivência e o acompanhamento do crescimento. Também a Fred, meu "filho" e companheiro de quatro patas.

Por último, talvez por guardar o lugar mais importante, dedico minha gratidão à memória do meu pai, Braulino. Ele foi o meu primeiro e maior exemplo do que 
é tornar-se gente; também meu maior incentivador nos estudos. Dez anos se passaram desde a sua partida, mas ficam o amor infinito, a gratidão eterna e as lições de vida. Sua imagem é sinônimo de coragem, força, ternura e alegria; mesmo nas situações mais adversas, ele se mostrava incondicionalmente otimista, com um sorriso no rosto e muitos sonhos na cabeça. Somente hoje, com mais maturidade, percebo a grandeza do que nos ensinou. É com muita emoção e o coração cheio de saudade que escrevo essas últimas palavras, no desejo de dedicar a conquista da conclusão de mais uma etapa àquele que era o meu preferido. 
SUMÁRIO

Introdução

CAPÍTULO I

NEM TUDO ERA SERGIPANO: A ESCRITA DO MITO PIONEIRO E A INVISIBILIZAÇÃO INDÍGENA NAS ORIGENS DE ITABUNA

1.1 Os memorialistas e seu lugar de fala

1.2 A "civilização do cacau":

a construção de uma memória coletiva

1.3 A elaboração da acomodação do mito pioneiro regional para a história de Itabuna pelos intelectuais da década de 1960

$1.4 \mathrm{O}$ jogo de lembrar e esquecer: o afastamento de Ferradas na escrita da memória de Itabuna

1.5 Algumas reflexões acerca da atualização do mito pioneiro.

\section{CAPÍTULO II}

O ALDEAMENTO DE FERRADAS E A OCUPAÇÃO TERRITORIAL DE CACHOEIRA DE ITABUNA

2.1 Ocupação e exploração territorial: a instalação do aldeamento São Pedro de Alcântara, em Ferradas

2.2 Atuação dos capuchinhos no Aldeamento São Pedro de Alcântara. 


\section{CAPÍTULO III}

TERRITORIALIZAÇÃO E TRABALHO: ATUAÇÃO DOS ALDEADOS DE FERRADAS NOS SERVIÇOS PÚBLICOS E PARTICULARES.

3.1 Os delineamentos da política indigenista colonial e imperial voltados a atender às demandas de trabalho dos índios aldeados .150

3.2 Expansão territorial e trabalho: a construção da lavoura dos "frutos de ouro", no sul da Bahia oitocentista .158

3.3 O trabalho dos aldeados de Ferradas nos serviços públicos e particulares...............................................167

\section{CAPÍTULO IV}

\section{OS FLUXOS DE ENCONTROS NA FRONTEIRA} OITOCENTISTA EM CACHOEIRA DE ITABUNA .............205

4.1 Agenciamentos indígenas em Cachoeira de Itabuna: conflitos e negociações entre autoridades governamentais, religiosas, índios aldeados e não aldeados .208

4.2 O que era ser índio aldeado no Sul da Bahia?

Ressocialização dos grupos étnicos no processo de territorialização oitocentista .236

4.3 Que "feras" são essas? .244

\section{CAPÍTULO V}
A “EXTINÇÃO” DO ALDEAMENTO SÃO PEDRO
DE ALCÂNTARA: NAÇÃO, POLÍTICA
INDIGENISTA E INVISIBILIZAÇÃO
DOS ÍNDIOS NA ORDEM IMPERIAL 
5.1 Algumas reflexões sobre os direcionamentos acerca da inserção indígena na construção do Estado-nação

5.2 A “extinção" do aldeamento São Pedro de Alcântara e os primeiros passos da colônia nacional em Ferradas

5.3 Os meandros da política indigenista nas práticas administrativas no Sul da Província da Bahia e a ideia de desaparecimento dos índios do "antigo aldeamento" 285

CONSIDERAÇÕES FINAIS 295

ANEXOS 301

ANEXO 1 - Quadro 1: Aldeias da Província da Bahia com declaração do terreno, números de índios que as habitam, estado de civilização dos mesmos, Missionário que as dirigem, e vencimentos por estes recebidos

ANEXO 2 - Quadro 2: Aldeias dos índios da Província da Bahia .304

ANEXO 3 - Tabela 5: Assuntos tratados nas correspondências trocadas entre autoridades de Ilhéus e a presidência da Província da Bahia 307

ANEXO 4 - Tabela 6: População aldeada nas comarcas de Ilhéus e Porto Seguro (1856) 308

REFERÊNCIAS .309 


\section{INTRODUÇÃO}

Em avaliação acerca dos avanços dos estudos indígenas na América espanhola, decorridos a partir da década de 1970, John Monteiro assinalou que eles deixaram de girar em torno dos temas da conservação da tradição milenar e de cultura empobrecida, para se preocupar mais com as populações indígenas após o contato colonial. Desse processo, emergiu o "índio colonial", que "passava a desempenhar um papel ativo e criativo diante dos desafios postos pelo avanço dos espanhóis". ${ }^{1}$ Uma das características que marcaram os novos rumos da historiografia acerca dos índios na América espanhola foi a recorrência dos historiadores a um arsenal de fontes produzidas pelos índios, na experiência do contato, o que os fazia aparecer com sua própria voz na historiografia ${ }^{2}$.

Em contraponto à profusão de estudos indígenas na América espanhola, emergidos de novas fontes e novas abordagens, Monteiro ressalta a ausência de fontes produzidas pelos índios da América portuguesa, restringindo, assim, as abordagens historiográficas. Contudo, ele frisou não ser esse o principal problema para que os índios fossem incluídos como atores do processo colonial na historiografia brasileira. Para John Monteiro, o principal empecilho para a inclusão dos índios como atores da colonização residia na resistência dos historiadores à

1 MONTEIRO, John Manuel. Tupis, Tapuias e Historiadores: Estudos de História Indígena e do Indigenismo. Tese de livre docência. Unicamp, 2001, p.1.

2 Idem, p. 2. 
temática indígena, relegando-a ao campo da antropologia. Desse modo, parecia-lhe ainda muito arraigada, na historiografia brasileira, a afirmação de Varnhagen, para quem os índios não tinham história, apenas etnologia. ${ }^{3}$

Até a década de 1980, ainda segundo Monteiro, estavam presentes na historiografia brasileira duas tendências na história da colonização: uma excluía os índios da história, especialmente na condição de atores históricos; e outra os colocava como povos fadados ao desaparecimento, pelo viés da morte e da aculturação. Para o autor, a perspectiva da extinção cultural dos índios integrados à sociedade é nociva porque a ideia de aculturação faz emergir outra: a de que os índios, após o contato colonial, seriam "menos índios" que antes. Essa noção, por sua vez, dificulta "a compreensão dos múltiplos processos de transformação étnica que ajudariam a explicar uma parte da história social e cultural do país". ${ }^{4}$

A partir do final da década de 1970, Monteiro observou um novo desenho dos estudos indígenas entre historiadores e antropólogos. Nesse momento, os estudos indígenas estavam muito relacionados às experiências práticas do movimento indígena, especialmente acerca da sua luta pelos territórios tradicionais, empreendida a partir da ideia "dos direitos indígenas enquanto direitos históricos". Essa noção do direito dos índios como direito histórico "estimulou importantes estudos, que buscavam, nos documentos coloniais, os fundamentos históricos e jurídicos das demandas atuais dos índios". ${ }^{5}$ A reorientação teórica, por seu turno, sinalizava novas abordagens que levavam em conta as culturas indígenas e suas identidades

\footnotetext{
3 MONTEIRO, John Manuel. Op., cit., p. 3.

4 Idem, p. 5.

5 Idem, ibidem.
} 
como algo dinâmico na realidade posterior ao contato colonial. ${ }^{6}$ Contudo, John Monteiro ressaltou o caráter marginal que continuou ocupando a questão indígena na história do Brasil, mesmo quando as pesquisas coloniais em torno dos temas "esquecidos da história" explodiram, a partir do acesso dos historiadores a uma gama de arquivos e documentos até então inexplorados. ${ }^{7}$

Como parte do esforço de inclusão dos índios na história do Brasil, a partir da década de 1990, destacam-se os trabalhos do próprio John Monteiro, ${ }^{8}$ além dos estudos de João Pacheco de Oliveira e Maria Regina Celestino de Almeida. Esses estudiosos, além de fornecer rica contribuição, foram responsáveis, em grande medida, por animar e nortear uma profusão de estudos acerca das populações indígenas nos diversos programas de pós-graduação, nos últimos anos.

Os referidos autores são unânimes em afirmar que foi graças às aproximações entre história e antropologia o olhar da história para o cotidiano e o comportamento do homem comum e o interesse da antropologia pelas transformações sociais, que sofrem seus objetos de pesquisa ${ }^{9}-$ e os novos conceitos e abordagens metodológicas das fontes, que ambas as disciplinas foram capazes de tirar os índios da condição de simples objeto da colonização, ou povos em vias de desaparecimento pelos processos da mistura, para serem incluídos, na história, como atores de sua trajetória histórica.

6 MONTEIRO, John Manuel. Op., cit., p. 6.

7 Idem, p. 7.

8 A exemplo de Negros da Terra, estudo no qual Monteiro recuperou a importância da escravidão indígena como elemento-chave para pensar e compreender as bases da sociedade colonial paulista: Negros da Terra: índios e bandeirantes nas origens de São Paulo. São Paulo: Companhia da Letras, 1994.

9 ALMEIDA, Maria Regina Celestino de. Metamorfoses indígenas: identidade e cultura nas aldeias coloniais do Rio de Janeiro. 2 ed., Rio de Janeiro: Editora FGV, 2013, p. 28. 
João Pacheco de Oliveira observou o desinteresse dos antropólogos em estudar as populações indígenas do Nordeste, pois, nos moldes americanistas e europeus de meados do século XX, tratava-se de uma "etnologia menor", por referir-se aos índios misturados. ${ }^{10}$ Os índios do Nordeste foram frequentemente caracterizados como povos em processo de perdas culturais, como os classificou Eduardo Galvão ${ }^{11}$; ou povos residuais, como os classificou Darcy Ribeiro. ${ }^{12}$ Também o órgão indigenista manifestava incômodo em trabalhar com os "índios do Nordeste" por eles se distanciarem, culturalmente, das populações comumente atendidas em outras regiões, como as populações da Amazônia. ${ }^{13}$

Oliveira usou o conceito de etnogênese para tratar o processo histórico e social vivenciado pelos "índios do Nordeste". Desse ponto de vista, o foco muda da ideia de perda cultural para a ideia da reconstrução da cultura das populações indígenas em processo de mistura. Pacheco de Oliveira ressaltou, portanto, que as expressões "índios do Nordeste" ou "índios misturados" "merecem uma ordem de atenção, pois permitem explicitar valores, estratégias de ação e expectativas dos múltiplos atores presentes nessa situação interétnica". ${ }^{14}$

O estudo de Maria Regina Celestino de Almeida se constitui em um dos marcos para compreender a trajetória das populações indígenas na história colonial do Brasil. Seu estudo acerca das aldeias coloniais do Rio de Janeiro analisa

10 OLIVEIRA, João Pacheco de. Uma etnologia dos índios misturados?" Situação colonial, territorialização e fluxos culturais. Mana. Rio de Janeiro, v. 4, n. 1, p. 47-77, 1998.

11 Idem, p. 49.

12 Idem, p. 50.

13 Idem, p. 52.

14 Ibidem. 
as mudanças históricas e sociais vivenciadas pelos índios na realidade do contato. Tais mudanças deflagraram transformações profundas e reorientaram a vida dos índios nos aldeamentos. Em sua abordagem, Almeida reitera o argumento de John Monteiro sobre o caráter teórico da "nova historiografia indígena", que percebe sua orientação a partir da realidade atual de reconstrução das identidades e das lutas por direitos das populações indígenas. ${ }^{15}$

Celestino de Almeida sublinha a noção de cultura como produto histórico e dinâmico, no qual a simplista ideia de cultura pura ou perda cultural cede lugar à ideia de cultura em movimento, transformada nas e pelas experiências do contato colonial. Nesse escopo analítico, o autor propõe pensar os aldeamentos em termos de uma resistência adaptativa, estratégia desenvolvida no processo de colonização, processo no qual os índios interagiram com os agentes coloniais e foram capazes de reorientar suas vidas e sua cultura. ${ }^{16}$

No cenário sul baiano, vale dizer que o movimento de inclusão dos índios na história ainda é muito tímido. Os estudos indígenas sobre o sul da Bahia, mais especificamente, os voltados para a capitania e a posterior comarca de Ilhéus são bastante reduzidos. Dentre os trabalhos disponíveis estão os estudos pioneiros de Luiz Mott e Maria Hilda Baqueiro Paraíso ${ }^{17}$.

O estudo de Luiz Mott sobre os índios do sul da Bahia, republicado recentemente no livro Bahia: inquisição e

15 ALMEIDA, Maria Regina Celestino de. Op., cit., p. 33.

16 Idem, p. 34.

17 MOTT, Luiz. Bahia: Inquisição e Sociedade. Salvador: EDUFBA, 2010; PARAÍSO, Maria Hilda Baqueiro. O Tempo da Dor e do Trabalho: A conquista dos territórios nos sertões do leste. Universidade de São Paulo. Tese de doutorado, 1998. 
sociedade, que se constitui na compilação de uma série de artigos produzidos pelo autor, foi publicado originalmente em 1988. Esse artigo gira em torno, principalmente, das denúncias de "pecados públicos", feitas no "Livro de Devassas da Visita das Freguesias da Comarca do Sul da Bahia", contra 12 freguesias, sendo quatro delas antigas aldeias indígenas. ${ }^{18}$ Seu foco de análise foi a moralidade e a sexualidade das etnias da região, em meados do século XVIII ${ }^{19}$.

O estudo de Maria Hilda Paraíso se concentrou na área denominada de "zona tampão", entre a Bahia, Minas Gerais e Espírito Santo, compreendendo os rios de Contas e o Doce, entre os anos de 1808 e 1897. O estudo teve por objetivo analisar os processos sociais estabelecidos entre as populações indígenas e os agentes da colonização. Paraíso ressaltou que aquele foi um "período em que ocorreu o devassamento, conquista e colonização da região e foram estabelecidas diversas formas de dominação das populações indígenas que a habitavam ou ali haviam buscado refúgio" ${ }^{\prime 20}$.

Posteriormente a esses estudos, foram realizadas outras duas importantes pesquisas que evidenciam a atuação dos índios na história do sul da Bahia. A tese de Marcelo Dias discute a ideia de falência da Capitania de Ilhéus e defende que ela não se encaixava no modelo colonial da economia do açúcar. De forma peculiar, a capitania atendia uma dinâmica de produção voltada para o abastecimento do mercado interno. Embora o norte do seu trabalho não seja a questão indígena no sul da Bahia colonial, Dias fornece rica contribuição à temática indígena,

18 MOTT, Luiz. Bahia: inquisição e sociedade. Salvador: EDUFBA, 2010, p. 196.

19 Idem, p. 198.

20 PARAÍSO, Maria Hilda Baqueiro. O Tempo da Dor e do Trabalho: A conquista dos territórios nos sertões do leste. Universidade de São Paulo. Tese de doutorado, 1998, p. 19. 
pois os inclui na história da região. Ao contrário da ideia de ferocidade comumente atribuído aos índios da capitania, Marcelo Dias ressaltou a importância do trabalho dos aldeamentos jesuíticos na Capitania de Ilhéus, inclusive movimentando o comércio entre a capitania e o Recôncavo. O autor afirmou que os aldeamentos da Capitania de Ilhéus "constituíram-se como parte integrante de um sistema produtivo muito original que se desenvolveu na Capitania, o qual articulava à agricultura de gêneros alimentícios, sobretudo da mandioca para farinha, a extração e beneficiamento de uma gama de produtos vegetais" 21 .

Recentemente tivemos acesso ao estudo de Teresinha Marcis, que analisa a aplicação do Diretório dos Índios no sul da Bahia. Ela observa que, na Bahia, o Diretório não foi aplicado integralmente; alguns direitos históricos dos índios, como "a manutenção das terras do aldeamento como patrimônio coletivo," foram mantidos. Além disso, a autora assevera que também foi garantida aos índios certa autonomia política, pois a preferência quanto à ocupação dos cargos de vereadores e juízes ordinários das vilas recaía sobre os índios ${ }^{22}$. Em sua tese de doutoramento, Marcis se ocupa em compreender "as trajetórias e experiências dos moradores indígenas dos aldeamentos jesuíticos extintos e transformados em vilas" ${ }^{23}$ na Capitania e posterior Comarca de Ilhéus, sob a égide do Diretório pombalino.

21 DIAS, Marcelo Henrique. Economia, sociedade e paisagens da capitania e comarca de Ilhéus no período colonial. Tese de doutorado. Universidade Federal Fluminense: Niterói-RJ, 2007a, p. 193.

22 MARCIS, Teresinha. A integração dos índios como súditos do Rei de Portugal: uma análise do projeto, dos autores e da implementação na capitania de Ilhéus, 1758-1822. Tese de doutorado. Universidade Federal da Bahia. Salvador-BA, 2013, p. 22.

23 MARCIS, Teresinha. Op., cit., p. 22. 
No esforço de contribuir para a inclusão dos índios na história da região Sul da Bahia, o objetivo deste estudo é compreender a prática do empreendimento colonizador e a atuação indígena na comarca de Ilhéus, sul da Bahia, durante o século XIX, região hoje conhecida como Itabuna. Nossa preocupação é pensar, de um lado, o funcionamento das estratégias políticas e administrativas indigenistas, com vistas a garantir, através do processo de territorialização dos índios em aldeamentos, a exploração do trabalho das populações indígenas para o êxito do projeto imperial na região; de outro, as agências indígenas nesse processo, e pensar e analisar os índios de Ferradas como atores de sua trajetória histórica no mundo da colonização oitocentista no Sul da Bahia.

É importante tratar a exploração do trabalho indígena por parte do governo e de particulares, e as diversas formas de violência a que muitas vezes os índios eram submetidos, bem como a tentativa de invisibilização deles na região, após a extinção do aldeamento de Ferradas. Em todos esses processos é possível pensar o desenho contemporâneo da realidade vivenciada por estas populações. Suas vidas foram profundamente modificadas ao longo do processo da colonização e os seus direitos violados, sobretudo o direito à terra. Isso diz muito sobre as lutas, desejos e sonhos das populações indígenas do sul da Bahia atualmente.

Também é igualmente importante falar das estratégias e das negociações estabelecidas na relação dos índios com os diversos agentes da colonização. Esse aspecto permite recuperar a historicidade dos camacãs, pataxós e guerens da Região, atores que se transformaram ao longo dos múltiplos processos vivenciados na realidade da colonização oitocentista. Portanto, nos dedicamos a recuperar os interesses públicos e particulares na exploração compulsória do trabalho indígena e as respostas e as agências indígenas como outra 
face do mesmo processo. Suas ações, fosse por meio da guerra ou da negociação, não eram reações impensadas em relação à "situação colonial". Eram lutas de diferentes atores em defesa de suas possibilidades e projetos, ou, em outras palavras: conforme podiam, os índios defendiam a possibilidade de projetos alternativos, que lhes garantissem a sobrevivência. Na medida do possível, eles reorientaram suas vidas a partir da interação no mundo da colonização sul baiana, no século XIX. Essa é uma leitura importante a ser feita, pois, novamente pensando a realidade atual das populações indígenas do Sul da Bahia, podemos inferir que os índios não foram extintos social e culturalmente como parecia empreender o discurso oficial de fins do XIX. Eles modificaram-se e permaneceram na região, participando das transformações históricas e sociais daquela parte do Sul da Bahia.

A documentação utilizada em nossa pesquisa compreende uma diversidade de fontes: escritos memorialistas, cartas pessoais, jornais, escrituras de compra e venda de terra, relatórios presidenciais provinciais e as correspondências oficiais (ofícios, requerimentos, queixas, dentre outras) de autoridades e missionários. Contudo, as correspondências oficiais trocadas entre o governo local e a Capital da Província tiveram um peso maior na orientação do traba1ho. Através do diálogo com a "nova historiografia indígena" e algumas reflexões suscitadas pela aproximação com a "historiografia do trabalho", tentamos ultrapassar a exterioridade da documentação oficial e apreender em, uma leitura a contrapelo do discurso oficial, as diversas formas de atuação indígena no processo da colonização.

O trato da documentação, afinado às leituras realizadas, apontou para uma reorientação da pesquisa. Algumas fontes acessadas ao longo da pesquisa de mestrado permitiu o aprofundamento de questões importantes, como os interesses das autoridades religiosas, governamentais, bem 
como por particulares da região permeavam a instalação do aldeamento São Pedro de Alcântara, em Ferradas. Isso ficou claro na análise das cartas trocadas entre Frei Ludovico e Balthazar da Silva Lisboa. Também o tema do trabalho indígena, presente em quase todo o texto e norteador de grande parte das argumentações empreendidas neste estudo, surgiu a partir do amadurecimento da pesquisa, com as leituras e análises das fontes e o diálogo com a bibliografia levantada e estudada.

O primeiro capítulo funciona, no presente estudo, como antessala das discussões propostas, nos capítulos seguintes, acerca do processo de ocupação territorial da região Cachoeira de Itabuna, sul da Bahia, e a atuação dos indígenas aldeados naquele processo. Nesse capítulo, objetivamos apresentar o processo de construção da memória de origem de Itabuna por parte das elites política e intelectual locais forjada na década de 1960. Elas evocaram o pioneirismo dos seus antepassados, os migrantes sergipanos, e, como contrapartida, uma estratégica invisibilização do aldeamento e dos índios de Ferradas.

O segundo capítulo procura analisar o processo de transferência dos guerens do extinto aldeamento do rio Almada para Ferradas e a instituição do aldeamento São Pedro de Alcântara no mesmo local, no qual passaram a coabitar os índios guerens do Almada, os camacãs ali aldeados e os pataxós que viviam nos espaços limítrofes do aldeamento. Além do processo de instalação do aldeamento, nos ocupamos, nessa etapa do estudo, em compreender os interesses governamentais e particulares que permeavam a instalação do aldeamento de Ferradas. Salientamos o papel de Balthazar da Silva Lisboa que, na condição de Ouvidor da Comarca de Ilhéus e como suposto proprietário de terras naquela área, transferiu os índios do Almada e fundou a aldeia de Ferradas, em 1814. 
No terceiro capítulo, o objetivo é demonstrar a atuação do trabalho dos aldeados de Ferradas nos ramos dos serviços públicos e particulares. Além de analisarmos o uso de sua mão de obra em Cachoeira de Itabuna e Ferradas, região que hoje compreende a cidade de Itabuna, observamos os aldeados de Ferradas trabalhando nas áreas vizinhas, como nas fazendas de cacau do rio Almada, por exemplo. Nossa atenção recai sobre a utilização da mão de obra indígena de forma compulsória nos trabalhos da estrada Ilhéus-Conquista, bem como na lavoura do cacau. O sul da Bahia configurou-se, no decorrer do século XIX, em "região cacaueira". Esforçamo-nos para demonstrar que, nesse processo, o trabalho dos homens e mulheres do aldeamento de Ferradas foi importante para a nova conformação social, política e econômica regional.

No quarto capítulo deste estudo, o objetivo central é tentar mapear, analisar e compreender as relações interétnicas estabelecidas naquela situação de contato, para além das situações de trabalho e demonstrar que, em Ferradas, tanto os camacãs e guerens aldeados quanto os camacãs, botocudos e pataxós não aldeados, habitantes da região, participaram do processo da colonização de forma dinâmica. A ideia é evidenciá-los e mostrar que transformaram a história da colonização, no sul da Bahia oitocentista. Eles usaram diferentes estratégias: a guerra, com o objetivo de barrar, em alguma medida, o avanço da colonização sobre seus territórios, mas também a negociação, quando fizeram acordos com os frades e autoridades dos governos local e provincial.

No quinto e último capítulo, procuramos suscitar algumas reflexões sobre a política indigenista, do século XIX, para entender e situar a paulatina extinção dos aldeamentos e inserção dos índios no Estado-nação. Isso marca a emergência da ideia de extinção social e cultural dos índios dos 
antigos aldeamentos. Nesse sentido, nos esforçamos em captar, no discurso oficial, a tentativa de invisibilização social e cultural dos índios de Ferradas; à medida que o aldeamento foi extinto, também desapareceu, da documentação compulsada, o registro acerca dos índios que viviam no local. No intuito de entender o desenrolar do processo de extinção do aldeamento e verificar a presença e atuação dos índios do extinto estabelecimento, empreendemos algumas reflexões e, vale dizer, ainda bastante iniciais acerca desse problema. Verificamos, contudo, que os índios não desapareceram, mas foram ressemantizados nos discursos oficiais como membros das colônias agrícolas regionais. As colônias nacionais agrícolas transformaram-se, na segunda metade do século XIX, no novo projeto de colonização implantado na região e, conforme a observação preliminar das fontes pesquisadas, tudo indica que elas eram preferencialmente fundadas sobre os aldeamentos extintos do sul da Bahia. Assim, para entender a extinção do aldeamento de Ferradas é importante entender, mesmo que sumariamente, a criação da colônia Cachoeira, pois, ao que tudo indica, foi sobre o aldeamento de Ferradas ou São Pedro de Alcântara que nasceu a colônia.

Nossas fontes apontaram para diversos caminhos e possibilidades de análises, mas priorizamos algumas abordagens aqui apresentadas, consideradas as mais interessantes e viáveis para a compreensão do nosso objeto de estudo: os índios do aldeamento de Ferradas e as questões da realidade colonial com eles relacionadas. 
CAPÍTULO I 


\section{NEM TUDO ERA SERGIPANO: A ESCRITA DO MITO PIONEIRO E A INVISIBILIZAÇÃO INDÍGENA NAS ORIGENS DE ITABUNA}

No capítulo em questão, a proposta não é opor história e memória, mas tecer algumas observações acerca das operações concernentes a uma e a outra, especialmente no processo de construção da memória de origem de Itabuna, realizada por parte da elite política e intelectual da década de 1960, que evocou exclusivamente o pioneirismo dos seus antepassados, os migrantes sergipanos, para explicar o surgimento da cidade. Frisamos a possibilidade de escrituração de outras narrativas acerca da história e historicidade das origens de Itabuna; e propomos, nos capítulos seguintes, uma interpretação da história do sul da Bahia que abrigue os índios e as complexidades inerentes ao encontro dos diferentes atores no processo da colonização sul baiana.

Neste capítulo, recorreremos ao conceito de "representação", tal como discutido por Sandra Pesavento, em História e história cultural, a partir de seu diálogo com Marcel Mauss e Émile Durkheim ${ }^{1}$. Nossa proposta é

1 Cf. PESAVENTO, Sandra Jatahy. História e história cultural. 3. ed. Belo Horizonte: Autêntica, 2012, p. 40: Representar é, pois, fundamentalmente, estar no lugar de, é presentificação de um ausente; é um apresentar de novo, que dá a ver uma ausência. A ideia central é, pois, a da substituição, que recoloca uma ausência e torna sensível uma presença. 
analisar a escrita memorialista de Itabuna como processo de construção da representação identitária sergipana, no qual se opera uma ausência proposital de outros atores sociais nas origens da cidade, para supervalorizar a figura dos sergipanos como pioneiros do progresso regional.

Analisaremos a narrativa memorialista sob a perspectiva discursiva, nos termos de Foucault, porque, nos jogos de representação foi construída, para Itabuna, uma identidade sergipana; e transformada, essa narrativa, em mito, pelos usos da memória. ${ }^{2}$ Nesses termos, entendemos que "um mito não é necessariamente uma história falsa ou inventada; é, isso sim, uma história que se torna significativa na medida em que amplia o significado de um acontecimento individual (factual ou não), transformando-o na formalização, simbólica e narrativa, das autorrepresentações partilhadas por uma cultura [ou por um grupo]" ${ }^{3}$.

Entendemos que o conceito de discurso, presente em nosso estudo, dialoga, sem problema algum, com o conceito de representação, pois no jogo das representações da escrita da memória, as escolhas são construídas por práticas discursivas. A produção discursiva, para Foucault, envolve procedimentos de exclusão; ela "é ao mesmo tempo controlada, selecionada, organizada e redistribuída" ${ }^{4}$. Nesse sentido, o autor nos apresenta três procedimentos de exclusão da produção discursiva: a interdição, a separação e a vontade de verdade. É à última que Foucault dá

2 FOUCAULT, Michel. A ordem do discurso: aula inaugural no Collège de France, pronunciada em 2 de dezembro de 1970. 22. ed. São Paulo: Edições Loyola, 2012.

3 PORTELLI, Alessandro. "O massacre de Civitella Val di Chiana (Toscana, 29 de junho de 1944): mito e política, luto e senso comum". In: AMADO, Janaína; FERREIRA, Marieta de Moraes (Orgs.). Usos e abusos da história oral. 8 ed., Rio de Janeiro: FGV, 2006, p. 120-121.

4 FOUCAULT, Michel. Op., cit., p. 8. 
maior atenção. Nossa intenção é refletir sobre o desejo de dizer o verdadeiro incutido no discurso da escrita da memória de Itabuna. Vale ressaltar que, para Foucault, o discurso não é uma vontade de poder: ele é poder. Nas palavras do autor, "o discurso não é simplesmente aquilo que traduz as lutas ou os sistemas de dominação, mas aquilo porque, pelo que se luta o poder do qual nos queremos apoderar". ${ }^{5}$

Sendo assim, na construção da narrativa memorialista itabunense, quem detém a hegemonia da construção da memória também detém o poder de narrar a história das origens da cidade evidenciando a presença e a atuação dos antepassados sergipanos em detrimento de outros sujeitos, que desaparecem nessa narrativa. Em consequência disso, o discurso memorialista legitima o poder social e político dos herdeiros do cacau, diante da sociedade itabunense. Dessa forma, a construção de uma memória sergipana e a obliteração do índio, invisibilizado na narrativa, constituem-se no objeto de estudo deste capítulo.

\subsection{Os memorialistas e o seu lugar de fala}

Na década de 1960, no momento dos festejos em comemoração ao cinquentenário de emancipação política da cidade de Itabuna, alguns intelectuais e políticos da cidade se ocuparam em escrever a história de Itabuna, na qual os seus antepassados são evocados como os pioneiros e precursores de um presente cheio de progresso. Era o grande progresso que lhe conferia, aliás, o título de "Rainha da Bahia". Os escritos memorialistas foram os mais

5 FOUCAULT, Michel. Op., cit., p. 10. 
utilizados, posteriormente, por todos aqueles interessados em escrever sobre Itabuna e que, ao longo do tempo, tornaram-se porta-vozes da história da cidade, através da atualização da narrativa da memória construída nos anos 1960. Os livros fundadores da memória da cidade são: Documentário histórico ilustrado de Itabuna, de José Dantas de Andrade, de 1968; Terras de Itabuna, de Carlos Pereira Filho, de 1960; O jequitibá da Taboca, de Oscar Ribeiro Gonçalves, de 1960.

Inexistem informações satisfatórias sobre os autores acima citados, salvo algumas recolhidas em notas de livros ou fontes hemerográficas. Essa lacuna, produzida pela falta de trabalhos sobre os referidos autores, é importante registrar, pois embora suas obras sejam recorrentemente visitadas, não há um trabalho biográfico sobre os memorialistas da cidade, ou disponibilidade de informações mais precisas sobre eles.

Analisando as matérias do jornal Diário de Itabuna, da década de 1960, podemos recolher em uma página ou outra, algumas informações sobre a atuação social e política de alguns desses autores. O diretor e proprietário do jornal Diário de Itabuna, Ottoni Silva, por exemplo, em uma nota do dia 14 de maio de 1960, parabenizava o escritor e jornalista Carlos Pereira Filho, autor de Terras de Itabuna, e pontuava sua atuação em defesa dos interesses da lavoura do cacau, isto é, "[...] como procurador das associações que representam os interesses da lavoura cacaueira"6. A relevância conferida à Pereira Filho por Ottoni Silva fica em evidência quando do seu apelo para que a sociedade itabunense fizesse aquisição daquela obra. Em uma nota do mês de agosto do mesmo ano, fazendo menção ao lançamento

6 CEDOC; Diário de Itabuna, ano III, nº 698, 14 de maio de 1960. 
do livro de Pereira Filho, Ottoni conclama: "vá imediatamente a qualquer livraria local e adquira, por Cr\$150,00 apenas, o interessante livro Terras de Itabuna"7.

Entendemos que o apelo de Ottoni não era simplesmente para que a sociedade itabunense adquirisse o livro de Pereira Filho, era também, e mesmo principalmente, uma manifestação do desejo de tornar pública e legítima a história engendrada naquele livro. Pois, como bem observa Halbwachs, "a memória de uma sociedade se estende até onde pode - quer dizer, até onde atinge a memória dos grupos de que ela se compõe $e^{\prime}{ }^{8}$ Dessa forma, a narrativa da história do pioneiro de Itabuna se constituía no esforço da atualização da memória pioneira construída para a região Cacaueira, desde o início do século XX.

José Dantas de Andrade mantinha um programa de rádio, na Rádio Clube de Itabuna. Em nota no Diário de Itabuna, Ottoni ressaltava: "A história de Itabuna está sendo contada. Todos têm a palavra. Os contemporâneos de Tabocas vêm às nossas colunas e ao microfone da Rádio Clube de Itabuna, no programa do Dantinhas, para falar o que sabem" ${ }^{\prime \prime}$. É importante ressaltar que a Rádio Clube pertencia ao mesmo grupo do jornal Diário de Itabuna e ambos os veículos de comunicação da cidade, à época, estavam envolvidos na empreitada da construção da história de Itabuna.

Já Oscar Ribeiro Gonçalves era professor e foi prefeito da cidade de São Félix, no Recôncavo baiano. Ao que tudo indica, ele escreveu O Jequitibá da Taboca por encomenda,

7 CEDOC; Diário de Itabuna, Quarta-feira, 17 de agosto de 1960, Ano III, n 730, p. 4.

8 HALBWACHS, Maurice. A memória coletiva. São Paulo: Centauro, 2003, p. 105.

9 CEDOC; Diário de Itabuna, 16 de julho de 1960, ano III, nº 739, s/p. 
na ocasião das comemorações do cinquentenário de Itabuna ${ }^{10}$. O conteúdo da obra consiste no registro dos relatos orais de um antigo morador da cidade, Manoel Bonfim Fogueira.

A atuação dos intelectuais da década de 1960 nos órgãos de imprensa, seja falada ou escrita, permite perceber, na relação da narrativa memorialista com a imprensa, o esforço de construir uma história oficial e homogênea para Itabuna, pois os discursos da escrita da memória e a pauta de trabalho da imprensa da cidade, naquele ano, complementavam-se. Era interessante reproduzir, na imprensa, a versão narrada nos livros memorialistas, pois, dentre os demais meios de comunicação utilizados pelos intelectuais de Itabuna, o rádio, por exemplo, tinha um alcance abrangente, veiculava informações em todas as camadas da sociedade. Tal atuação na imprensa demonstra, ainda, como esses memorialistas circulavam social e politicamente, visto que os jornais eram importantes espaços de veiculação de ideologias e disputas políticas.

O jornal Diário de Itabuna foi fundado em 1957, tinha como diretor o jornalista Ottoni Silva e circulava no trecho Itabuna-Ilhéus e em outras cidades menores, como Itapé, Ibicaraí, Itapetinga, Buerarema, Juçari, Camacã, Coaraci e Banco Central ${ }^{11}$.

Como veremos no próximo tópico, a história e a política na região cacaueira guardavam relações muito estreitas,

10 Plínio de Almeida, no prefácio de O Jequitibá da Taboca, esclarecia que havia a possibilidade de que o leitor encontrasse "alguns descuidos" na obra [apresentada], em face do curto espaço de tempo que o autor teria tido para apresentar o livro: GONÇALVES, Oscar Ribeiro. O jequitibá da Taboca: ensaios históricos de Itabuna. Itabuna: Oficinas Gráficas da Imprensa da Bahia, 1960, p. 16.

11 RIBEIRO, Danilo Ornelas. Do fazer jornalístico às sociabilidades de elites: a construção da Itabuna moderna (1957-1964). Monografia. Universidade Estadual de Santa Cruz: Ilhéus, 2010, p. 18. 
e poderíamos até dizer que uma legitimava e referendava a outra. Nessa perspectiva, ressaltamos que o lugar de herdeiros dos precursores do cacau, no qual estavam inseridos os intelectuais e políticos envolvidos em escrever a história de Itabuna, na década de 1960, diz muito sobre a sua produção.

\subsection{A "civilização do cacau": a construção de uma me- mória coletiva}

Ao longo do século XX, o sul da Bahia foi se configurando, por meio da escrita da memória, da literatura, dos estudos acadêmicos e técnicos, no que Adonias Filho denominou de "civilização do cacau". Dessa maneira, a região assume uma identidade do cacau. Para Adonias Filho, a região guardava peculiaridades engendradas pela geografia, estrutura social e organização econômica, que lhe conferiam um caráter de unidade, denominada, por ele, de um "pequeno país". Uma civilização que, nos termos do autor, foi cunhada pela inter-relação de imigrantes estrangeiros e nacionais, negros e índios, resultando na "identidade grapiúna". Hoje, o termo grapiúna faz referência apenas aos itabunenses ${ }^{12}$.

Nas páginas seguintes deste tópico, nos ocuparemos em entender a construção da memória da "civilização do cacau". As disputas pela memória refletiam as disputas de poder político na região. Entender a construção da memória coletiva para a região cacaueira, engendrada ao

12 DANTAS, Robson Norberto. Entre a arte, a história e a política: Itinerários e representações da "ficção brasiliana" e da nação brasileira em Adonias Filho (1937-1976). Tese de doutorado. UNICAMP, Campinas: São Paulo, 2010, p. 180-181. 
longo do século $X X$, nos possibilita analisar a apropriação e acomodação dessa memória pelos intelectuais e políticos de Itabuna da década de 1960, com o fim de engendrar a construção da versão pioneira sergipana, que, por sua vez, explicaria as origens de Itabuna.

A análise da escrita memorialista da região cacaueira como uma construção coletiva se dá nos termos de Maurice Halbwachs, para quem toda memória é coletiva, já que a memória individual é penetrada pela memória coletiva. Halbwachs salienta que a construção da memória é possível porque o indivíduo evoca palavras e ideias exteriores a ele, tomadas de empréstimo do seu ambiente ${ }^{13}$. Em outras palavras, a memória de um indivíduo não é construída fora do tempo e do espaço; ao contrário disso, ela faz parte da memória do grupo social ao qual pertence.

Halbwachs observa que o grupo nacional do qual faço parte vivenciou uma série de acontecimentos acerca dos quais digo que me lembro, mas que conheci apenas através dos jornais ou do testemunho de quem os vivenciou diretamente: "quando os evoco, sou obrigado a me remeter inteiramente à memória dos outros, e esta não entra aqui para completar ou reforçar a minha, mas é a única fonte do que posso repetir sobre a questão"14. Também a memória que julgamos individual, com base em nossas próprias lembranças, tem como referência uma carga de informações culturais e sociais que as enquadra e, por isso mesmo, é coletiva. Nas palavras de Halbwachs, "a lembrança é uma imagem introduzida em outras imagens, uma imagem genérica transportada ao passado" ${ }^{15}$.

13 HALBWACHS, Maurice. Op., cit., p. 72.

14 Idem, ibidem.

15 Idem, p. 93. 
Mary Ann Mahony observa que, nas primeiras décadas do século $\mathrm{XX}$, motivado por diversos fatores, em nível nacional e internacional, houve o grande boom do cacau na região sul da Bahia, cujos principais expoentes foram as cidades de Ilhéus e Itabuna. Naquele momento, uma luta pela memória da região cacaueira, que muito tinha a ver com as disputas políticas, começou a ser travada entre uma aristocracia advinda dos bem nascidos, descendentes dos antigos senhores de engenho de Ilhéus, e as famílias ricas de Salvador, que passavam a investir em cacau, de um lado; e, de outro, os "novos ricos". Para Mahony, "os proprietários novos ricos [...] eram um grupo muito diferente [das famílias tradicionais de Ilhéus], dado que saíram das camadas baixas da sociedade"16. Tratava-se dos imigrantes e migrantes pobres, descendentes de índios e de escravos, que enriqueceram com a lavoura do cacau.

Para Mahony, o grande problema era a recusa da elite tradicional de Ilhéus em aceitar, na mesma classe social, aqueles que a ela se igualavam apenas em termos de riqueza, os novos ricos. Para a elite ilheense, aqueles homens, "no máximo, eram pouco mais do que uns lavradores caboclos ou mulatos e, na pior das hipóteses, ex-escravos arrogantes com dinheiro" ${ }^{17}$. Os novos ricos, ao mesmo tempo em que se ressentiam pela maneira como eram vistos e tratados pela elite aristocrática, sentiam-se explorados por ela e orgulhavam-se de contribuir para a riqueza do Estado. Somados todos esses aspectos sociais e políticos, "os novos ricos" passaram a

16 MAHONY, Mary Ann. Um passado para justificar o presente: memória coletiva, representação histórica e dominação política na região cacaueira da Bahia. Especiaria, v. 10, n. 18, jul-dez., 2007. p. 746.

17 Idem, p. 748. 
lutar, num jogo político e de memória, pela construção de sua identidade como elite. Contudo, diferentemente dos bem nascidos, eles iriam evocar um passado de humildade e de trabalho pioneiro, que lhes conferia o lugar de elite do cacau. A dupla batalha, pela busca de um lugar na política e de um lugar social na história da região, estava presente nos discursos políticos de um desses novos ricos: Antônio Pessoa.

Os novos ricos, no início do século XX, ambicionavam, sem sucesso, cargos de representação política na região, realidade que fazia emergir uma disputa política violenta entre pessoístas e adamistas (ambas as terminologias são utilizadas para designar os dois grupos rivais na política ilheense à época, representados por Antônio Pessoa e Domingos Adami Sá). No jornal A Gazeta de Ilhéus, de propriedade de Antônio Pessoa, este deixava em evidência que os seus inimigos políticos eram Domingos Adami Sá, Ernesto Sá Bittencourt Câmara e seus aliados ${ }^{18}$. No cenário dessas disputas políticas, o principal recurso utilizado era a memória pioneira da região do cacau que estava sendo construída. Em seus discursos, Pessoa apresentava a si e a seus correligionários como homens que enriqueceram com o suor do próprio trabalho e faziam o contraponto com seus adversários, apontando-os como ex-senhores de escravos e aristocratas:

A estratégia de Pessoa era brilhante: identificava seus aliados - os novos ricos - com os trabalhadores, pequenos produtores e novos migrantes na região, e seus inimigos - os Adami - com os aristocratas e ex-senhores de escravos que dominaram os lugares onde eles nasceram. ${ }^{19}$

18 MAHONY, Mary Ann. Op., cit., p. 751.

19 Idem, p. 752. 
Os novos ricos, em 1911, conseguem, enfim, obter ascensão política na região. Como bem frisa Mahony, naquele ano, em vista do declínio político das elites tradicionais baianas, Antônio Pessoa conseguiu se eleger para a Assembleia Legislativa do Estado e, no ano subsequente, por intermédio do governador da Bahia, J.J. Seabra, ele conseguiu também a Intendência de Ilhéus ${ }^{20}$. Aquele momento marcou a era dos novos ricos no poder político da região. Pessoa manteve-se intendente de Ilhéus por muitos anos, sendo substituído por outro importante nome da política regional, o seu correligionário Misael da Silva Tavares. Vale lembrar que, àquela altura, Itabuna já se encontrava estabelecido como município independente de Ilhéus, cuja emancipação política se deu em 1910. O novo município era reduto dos pessoístas, tidos como representantes do grupo de Firmino Alves (considerado fundador da cidade).

O lugar hegemônico na política regional não bastava para os novos ricos. Como Mahony observou, a batalha política regional não se dissociava da batalha pelo lugar dessa nova elite na história da região cacaueira. Em 1914, por encomenda de Antônio Pessoa, Borges de Barros escreveu Memória sobre o município de Ilhéus. O livro faz um panorama dos tempos coloniais. Contudo, o eixo central da narrativa é a "civilização do cacau" e seus personagens principais: os pioneiros que enriqueceram com o trabalho na lavoura do cacau e tornaram-se prósperos, isto é, os novos ricos. Nas palavras de Mary Mahony: “Ao longo do livro, o progresso foi associado ao cacau e o cacau foi associado aos novos ricos e seus ancestrais". ${ }^{21}$

20 MAHONY, Mary Ann. Op., cit., p. 755.

21 Idem, p. 757. 
Na década seguinte, a conjuntura regional, impactada pelos acontecimentos internacionais, sobretudo econômicos, era outra. A crise econômica internacional dos anos 1920 se refletiu diretamente nos rumos da região sul da Bahia que, à época, era uma das principais exportadoras de cacau do mundo. Nesse processo, os abismos que separavam em batalhas violentas pessoístas e adamistas diminuem. Segundo Mahony, falou mais alto o interesse de classe diante da crise e as consequentes insatisfações dos trabalhadores rurais e grupos indígenas. ${ }^{22}$

Dessa forma, na nova geração, já não se fazia presente o separatismo adamista-pessoísta; ao menos, não como nos primeiros tempos da ascensão do cacau na região. $\mathrm{Na}$ nova fase, estabelecia-se um pacto de solidariedade de classe entre eles, particularmente visível nas alianças matrimoniais gestadas na região. Um exemplo desse pacto foi a ascensão política de Eusínio Lavigne, que guardava ancestralidade de ambos os grupos. Era descendente da tradicional família Sá, por um lado, e por outro, descendia de família imigrante, que chegou à região na segunda metade do século XIX. A aliança entre famílias tradicionais e os novos ricos culminou num programa de reforma relacionado ao cacau, que previa apaziguar as dificuldades socioeconômicas da região cacaueira. O programa de Lavigne para a região cacaueira

prometia estabelecer a ordem legal na região; promover a educação e a saúde nas zonas rurais e urbanas; melhorar a infra-estrutura, a pesquisa sobre o cacau e os programas de extensão agrícola; fazer lobby em favor do cacau baiano em capitais estrangeiras; estabelecer uma bolsa de valores para o

22 MAHONY, Mary Ann. Op., cit., p. 761. 
cacau com informações completas sobre as transações diárias no mercado estrangeiro; reformar o sistema de impostos; estabelecer cooperativas entre os produtores para negociar a compra e venda de cacau; e incentivar a industrialização do chocolate na própria região cacaueira. ${ }^{23}$

Na década de 1930, Eusínio Lavigne, quando intendente de Ilhéus e seguindo os passos de Antônio Pessoa, contratou João da Silva Campos "o mais importante historiador baiano da época, para escrever uma história de Ilhéus"24. Naquele contexto, a história a ser narrada abrigaria não mais os desagravos entre famílias tradicionais e novos ricos, mas uma história na qual, consensualmente, esses grupos apareceriam como os responsáveis pela expansão do cacau no sul da Bahia. A obra de Campos dissolvia a relevância das rivalidades políticas e evidenciava a escolha de Lavigne: uma história do cacau com base na cooperação e no trabalho de ambos os grupos. Como observa Mahony, o apelo à unidade se fazia importante em um contexto de crise econômica na região.

A crise econômica internacional da década de 1920 havia deixado, em 1930, os produtores de cacau quebrados ou muito endividados, e isso impactava diretamente na realidade dos trabalhadores rurais, que diante das dificuldades se mostravam insatisfeitos e começavam a se organizar contra os fazendeiros. Contudo, outro apelo estava incutido na nova narrativa histórica que o poder político da região se empenhava em construir. Tratava-se do papel de relevância dos "desbravadores" e produtores de cacau para a economia do Estado. O objetivo era legitimar, junto aos governos

23 MAHONY, Mary Ann. Op., cit., p. 762.

24 Idem, p. 764. 
estadual e federal, a obtenção de socorro financeiro aos cacauicultores. ${ }^{25}$

Na década de 1950, após a Segunda Guerra, os cacauicultores do sul da Bahia enfrentaram outra crise do cacau. Naquele momento, a narrativa da história da região do cacau e a história da atuação pioneira novamente vêm à tona. Entretanto, diferentemente do perfil das obras anteriores, tal discurso perpassava textos técnicos, acadêmicos e oficiais de vários estudiosos envolvidos em pesquisas sobre a região cacaueira na década de 1950. ${ }^{26}$

A economia cacaueira do sul da Bahia viveu movimentos cíclicos, ora com crescimento de vulto, ora com avassaladoras crises. Robson Dantas observa que, da década de 1930 até o final da década de 1960, “o Sul da Bahia viveu entre o desânimo e a expectativa de reversão da crise econômica do cacau" ${ }^{27}$. Dantas ressalta que o tema do desenvolvimento debatido no cenário nacional também estava presente não somente nos estudos econômicos e sociais acerca da economia cacaueira, mas também na literatura que envolvia o sul da Bahia. Em seu estudo, Dantas se preocupa em analisar o tema do desenvolvimento regional sob a ótica adoniana, bem como dialoga com a obra amadiana nas suas reflexões acerca do tema.

O tema do desenvolvimento da região cacaueira foi explorado na literatura de Jorge Amado, sobretudo em Terras do Sem Fim, publicado em 1942, e em São Jorge dos Ilhéus, publicado em 1944. Adonias Filho abordou o tema em Os Servos da Morte, de 1946; Memórias de Lázaro, publicado em 1952; Corpo Vivo, de 1962; Léguas da Promissão, de

25 MAHONY, Mary Ann. Op., cit., p. 765.

26 Idem, p. 773.

27 DANTAS, Robson Norberto. Op., cit., p. 145. 
1968; e As Velhas, este publicado em 1975. Jorge Amado retomou o tema em 1986, com Tocaia Grande, a face obscu$\mathrm{ra}^{28}$. Vale lembrar que tanto Jorge Amado quanto Adonias Filho faziam parte das famílias dos "novos ricos". Eles eram herdeiros dos denominados pioneiros da lavoura do cacau e colocavam-se na discussão sobre o desenvolvimento regional de modo muito próximo do discurso, que cunhava a ideia do pioneirismo da região cacaueira.

\subsection{A elaboração da acomodação do mito pioneiro regional para a história de Itabuna pelos intelectuais da década de 1960}

A narrativa de desenvolvimento da região sul da Bahia ligada ao cacau e à ideia dos pioneiros do cacau, engendrada desde as primeiras décadas do século $X X$ por intelectuais e estudiosos, foi apropriada pelos intelectuais itabunenses na década de 1960. Eles, por sua vez, elegeram os migrantes sergipanos como protagonistas da construção de uma memória coletiva oficial de Itabuna, que tinha como principal fim construir uma identidade sergipana para a cidade.

Na década de 1960, os itabunenses comemoravam o cinquentenário de emancipação política do município e, no decorrer daquela década, foram publicadas três importantes obras da memória de Itabuna: O Jequitibá da Taboca, Terras de Itabuna e Documentário Histórico Ilustrado de Itabuna. Os festejos comemorativos avivam certo sentimento de pertencimento, motivado por símbolos e representações identitárias. Desse modo, a escrita memorialista de Itabuna atuou

28 DANTAS, Robson Norberto. Op., cit., p. 146. 
como geradora de uma identidade sergipana que, por sua vez, seria atualizada na memória coletiva da cidade.

Denominamos de escrita memorialista uma memória coletiva oficial de Itabuna. Isso significa dizer que o discurso produzido e organizado pelos grupos hegemônicos da cidade estão presentes nos textos acadêmicos, na literatura, nas comemorações cívicas locais, no hino cívico da cidade, nas palestras escolares no contexto do aniversário do município, no teatro, nas aulas de história regional. Enfim, a memória heroica sergipana, daqueles que trabalharam e venceram, foi construída através das práticas discursivas e das representações, engendrando uma identidade sergipana que não é apenas coletiva. Ela também assume caráter oficial e é atualizada a cada ano pela evocação dos símbolos identitários nos espaços públicos e nos rituais oficiais. Levando-se em conta que "a memória é um elemento essencial do que se costuma chamar de identidade [...] é não somente uma conquista, é também um instrumento e um objeto de poder" ${ }^{29}$, entendemos que a narrativa sobre a história de Itabuna legitima o poder social dos intelectuais e dos políticos da década de 1960. Eles se apresentam no lugar e com o papel social de herdeiros dos precursores do desenvolvimento e do progresso de Itabuna. Iremos analisar mais adiante, neste capítulo, a discussão acerca da identidade como representação social.

Veremos, no terceiro capítulo, que, ao longo do século XIX, as relações entre colonos, escravos e índios eram muito próximas, como foi o caso do trabalho desenvolvido na estrada Ilhéus-Conquista por índios aldeados e escravos de fazendeiros locais. Contudo, na narrativa da

29 LE GOFF, Jacques. História e memória. 5. ed., Campinas: São Paulo, Editora da Unicamp, 2003, p.469-470. 
memória de Itabuna não se faz nenhuma alusão à presença de escravos africanos ou afrodescendentes trabalhando ao lado dos migrantes pobres e, quanto aos índios, são mencionados de forma indireta e sem nenhuma participação no processo de colonização da região. Eles são mencionados, mas o são na medida em que o memorialista faz referência aos tempos de frei Ludovico ${ }^{30}$. Com a presença dos migrantes, eles se tornaram obstáculos, foram empurrados para as matas e estavam fadados a desaparecer. Esse discurso perpassa todas as narrativas apresentadas. $\mathrm{O}$ inexorável desaparecimento do índio estava associado à "incompatibilidade" de sua presença com a civilização que estava sendo plantada naquelas paragens. Além do mais, a mata, aos poucos, desaparecia para dar lugar às inúmeras pequenas e médias roças, bem como às grandes fazendas de cacau. Ou seja, na perspectiva da escrita memorialista, o índio e a mata (de forma correlacionada) desapareceriam em nome do progresso da região.

O Jequitibá da Taboca, de Oscar Ribeiro Gonçalves, publicado em 1960, carrega uma peculiaridade muito interessante para se pensar a construção da memória. A obra é elaborada com base nos relatos de Manoel Fogueira, um dos ditos pioneiros. Nesse sentido, na construção do enredo de Gonçalves, temos a intermediação de dois

30 Frei Ludovico de Livorno foi o primeiro frade capuchinho italiano designado como diretor do aldeamento São Pedro de Alcântara ou aldeamento de Ferradas, em início do século XIX. Ele atuou junto aos indígenas aldeados por três décadas e se configurou como um personagem fundamental acerca dos direcionamentos do trabalho indígena na região sul da Bahia. Além das relações estabelecidas com o governo provincial, ele mantinha uma estreita ligação com os particulares da região, o que lhe denotava grande prestígio político e social. Ele caracterizou-se, ao longo de sua atuação na região, como um grande administrador do trabalho dos homens e mulheres aldeados, atuou não apenas junto aos índios de Ferradas, mas em grande parte da região sul da Bahia. Ver os capítulos II e III. 
narradores, a de Manoel Fogueira, que através do relato oral narra a história do marco zero, ou seja, das origens de Itabuna; e a intermediação de Oscar Ribeiro Gonçalves que, através da escrita, nos termos de Foucault, controla, seleciona, organiza e redistribui os acontecimentos e personagens para dar sentido ao seu enredo.

$\mathrm{Na}$ obra em questão, a narrativa da memória passa por dois filtros acerca da realidade que se deseja representar: o primeiro está presente no relato oral do primeiro narrador, Manoel Fogueira, e o segundo filtro é apresentado na construção discursiva, que tem a intenção de narrar a escrita da memória, empreendida por Ribeiro Gonçalves: "A documentação fornecida para que o presente volume se transformasse em realidade é obra de um sincero pioneiro, o Sr. Manoel Bonfim Fogueira, dono da maior tradição oral que se possa imaginar, acerca do município e da cidade de Itabuna" ${ }^{11}$. Essas são as palavras iniciais do prefaciador de O Jequitibá da Taboca, Plínio de Almeida, que era membro da Academia de Letras de Ilhéus. Plínio de Almeida segue ressaltando que:

O Sr. Oscar Ribeiro, recolhendo os informes fornecidos pelo Sr. Manoel Bonfim Fogueira, não pretendeu fazer obra acadêmica, ou romanesca, ou crônica onde apenas palpitam as palavras cantadas de uma poesia sem bases reais. [...] $\mathrm{O}$ material fornecido pelo Sr. Fogueira é do tipo que se pode batizar de 'primeira água', isto é, material muito bom pela fidelidade, pela verdade buscada e encontrada. ${ }^{32}$

31 GONÇALVES, Oscar Ribeiro. O jequitibá da Taboca. Itabuna: Oficinas Gráficas da Imprensa da Bahia, 1960, p. 15.

32 Idem, p. 16. 
Para o prefaciador e também para o autor do livro, a narrativa com base nos relatos de Fogueira dava ao seu enredo o caráter de verdade. Não era um trabalho de história, que envolvia a interpretação do passado nem tampouco romance ou crônica com base na imaginação. A obra trazia, em si, o próprio acontecimento, através do relato de quem o viveu e dava testemunho da realidade vivida. Nessa perspectiva, acerca do caráter que envolve a história e a memória, a representação do passado, Pesavento, evocando Paul Ricoeur, lembra que "à História, estaria negada a pequena alegria do reconhecimento preservado à Memória. Aquele que evoca, chega à identificação da lembrança com o acontecido, objeto da rememoração: foi ele, foi lá, foi então, foi assim!"’33

O primeiro capítulo de O Jequitibá da Taboca é dedicado a situar o leitor acerca das origens da cidade, para em seguida dar conta da realidade de progresso a que estaria destinada Itabuna, como herança da coragem dos seus pioneiros: os primeiros sergipanos ali chegados. São considerados como os primeiros sergipanos desembarcados em Ilhéus e fixados na região próxima a Ferradas: Felix Severino de Oliveira ou Felix Severino do Amor Divino e Manoel Constantino. Segundo Ribeiro Gonçalves, ambos vieram da Chapada dos İndios, Estado de Sergipe. $\mathrm{O}$ lugar onde teriam escolhido se estabelecer ficava às margens do Rio Cachoeira e a ele teriam dado o nome de Marimbeta e em seguida o batizariam de Tabocas. Assim Gonçalves relata a primeira cena da chegada dos sergipanos à região:

Sozinhos, neste dito lugar ermo, como teriam eles contemplado aquele cenário?

33 PESAVENTO, Sandra Jatahy. Op., cit., p. 55. 
A mata, os caboclos e as feras eram seus únicos vizinhos, mas além outeiros hirsutos, reduzindo-lhes o horizonte, mais ao lado, corre o rio Cachoeira no meio do qual se divisavam ilhas com matas incultas, árvores cujas copas se entrelaçavam numa selvatiqueza rude; um céu pincelado de nuvens escuras quase sempre a chover. No deslumbramento desse espetáculo irradiava a luz solar como a flor da esperança na vibração da mocidade. Pois bem: nesse ambiente solitário habitava Felix Severino do Amor Divino e seu companheiro, o crioulo Manoel Constantino. ${ }^{34}$

Gonçalves menciona, como parte de um único universo, a presença conjunta da mata, dos caboclos e das feras. Esse é o contexto, em sua narrativa, do primeiro contato dos migrantes sergipanos com a região. O que isso pode significar? O termo "caboclo", apresentado na obra, não parece aludir à mestiçagem luso-tupi ${ }^{35}$, pois, tal como empregado por Gonçalves, o caboclo está em um cenário selvagem e sugere muito mais o "índio selvagem", o botocudo, tão mais presente, naquela realidade regional, do que o mestiço. O caboclo aparece, portanto, representando o atraso, e mais como um obstáculo a ser vencido.

A ideia transmitida pela narrativa é a de lugar inculto, quase desabitado por gente, já que os índios são descritos ao lado da mata e das feras, portanto, uma extensão do mundo natural. A narrativa de Gonçalves faz emergir o discurso de que o índio das origens de Itabuna era "o

34 GONÇALVES, Oscar Ribeiro, Op., cit., p. 29.

35 MONTEIRO, John Manuel. Tupis, Tapuias e Historiadores: Estudos de História Indígena e do Indigenismo. Tese de livre docência. Campinas: Unicamp, 2001, p. 172. 
outro", que não fazia parte da história daquela parte do sul da Bahia. Mas, vale ressaltar que, àquela altura, no ano de 1844, descrito por Gonçalves como a data de chegada daqueles migrantes, a região era imensamente habitada. Ali viviam os grupos indígenas não aldeados, os aldeados, dentre eles, os de Ferradas, e ainda outros migrantes e estrangeiros que aos poucos já vinham habitando a região e tinham relações estreitas com os aldeamentos. O próprio Gonçalves reconhece que muitas das fazendas de cacau, construídas pelos novos habitantes e depois por outros conterrâneos, por ele relacionadas, já existiam anteriormente à Tabocas ${ }^{36}$. Contudo, era a história dos heróis sergipanos que deveria ser escrita e lembrada pela memória coletiva de Itabuna.

Em 2011, O Jequitibá da Taboca foi revisado, reeditado e publicado pela Editus, editora da Universidade Estadual de Santa Cruz (UESC), na ocasião do centenário de Itabuna, por Janete Ruiz de Macedo e João Cordeiro de Andrade, ambos integrantes do Centro de Documentação e Memória (CEDOC) da UESC. A professora Janete Macedo é uma importante pesquisadora e incentivadora da criação e manutenção dos arquivos municipais no sul da Bahia, trabalho realizado junto ao CEDOC. Ela explicita que o interesse em reeditar o raro livro O Jequitibá da Taboca se deu por dois objetivos: primeiro, atualizar as memórias de Manoel Fogueira para que todos, em especial os itabunenses, pudessem acessá-las; segundo, para tornar o livro disponível aos historiadores regionais, já que o considera uma fonte importante de estudo. ${ }^{37}$

36 GONÇALVES, Oscar Ribeiro, Op., cit., p. 28.

37 FOGUEIRA, Manoel Bonfim; GONÇALVES, Oscar Ribeiro. Ensaios históricos de Itabuna: O Jequitibá da Taboca, 1949-1960. 2. ed. Ilhéus: Editus, 2011, p. 27. 
Não obstante a importância de O Jequitibá da Taboca, entendemos que a reedição do livro, na ocasião do centenário da cidade, traz, em si, certo caráter de atualização da memória coletiva. A reedição dessa obra apresenta aos habitantes de Itabuna "um quadro de si mesma que certamente se desenrola no tempo, já que se trata de seu passado, mas de tal maneira que eles sempre se reconheçam nessas imagens sucessivas". ${ }^{38}$ Macedo conclui o texto de introdução ao livro da seguinte maneira:

\begin{abstract}
[...] espera-se que todos, em especial os itabunenses, jovens ou idosos, natos ou moradores, estudantes ou intelectuais, historiadores ou memorialistas, possam se apossar dessas memórias, e que haja a ambição de fidelidade ao passado, ameaçada quando as ideologias se intercalam entre a reivindicação de identidade e as expressões públicas da memória coletiva. ${ }^{39}$
\end{abstract}

A reedição da obra, apesar do caráter de atualização do mito pioneiro nela intrínseco, nos oportuniza estabelecer o diálogo entre a narrativa da memória e outros relatos documentais, por conseguinte, apontar a agência de outros sujeitos na narrativa da trajetória histórica de Itabuna; de modo particular, os índios de Ferradas, que foram invisibilizados na narrativa memorialista de 1960, objeto de estudo do trabalho em questão. Nesse sentido, ressaltamos, portanto, que as "ideologias" postas como "ameaças" à integridade do passado são muitas vezes reivindicações de outras identidades que desejam o alargamento da memória coletiva oficial de Itabuna.

38 HALBWACHS, Maurice. Op., cit., p. 109.

39 FOGUEIRA, Manoel Bonfim; GONÇALVES, Oscar Ribeiro. Op., cit., p. 29. 
Também é de 1960 a publicação de Terras de Itabuna, do jornalista Carlos Pereira Filho. A matéria publicada no Diário de Itabuna explicita o tom positivo com o qual a obra de Pereira Filho foi recebida entre os jornalistas e demais representantes do poder político e econômico da lavoura do cacau, de quem Pereira Filho era denominado de procurador:

[...] vimos cumprimentá-lo, hoje [...] em nosso nome [...] como ainda em nome da lavoura cacaueira, de quem se constitui um dos mais ardorosos advogados, não perdendo tempo, não tendo cansaços, toda vez que há necessidade de uma ação urgente, enérgica, como procurador das associações que representam os interesses da lavoura cacaueira. ${ }^{40}$

Em seu livro, Pereira Filho pontua o papel progressista da formação de Itabuna que, segundo ele, era consonante à própria trajetória de construção do Brasil. $\mathrm{O}$ autor faz um panorama da economia brasileira, que, em sua perspectiva, correspondia ao ciclo do açúcar, do ouro, do café e do cacau. Segundo Pereira Filho, naquela década (1960), ainda se vivia o tempo do café, do cacau e do gado, mas a economia de Itabuna, assim como a do Brasil, caminhava de forma acelerada para a industrialização ${ }^{41}$. Podemos refletir sobre dois aspectos da escrita deste autor: primeiro, não é demais lembrar que, na década de 1960, a região tentava se erguer de mais uma crise econômica do cacau. O momento parecia oportuno para lembrar o papel dos antepassados, considerados os responsáveis pelo

40 CEDOC; Diário de Itabuna, 14 de maio de 1960, Ano III, nº 698, p. 1.

41 PEREIRA FILHO, Carlos. Terras de Itabuna. Rio de Janeiro: Elos, 1960, p. 13-14. 
emergir grandioso de Itabuna. Mas ao salientar o papel da indústria como propulsora da economia regional, intrinsecamente está presente, no discurso do autor, a ideia de um caminho disponível para o progresso da região para além da economia cacaueira. A obra de Pereira Filho apresenta uma saída para a crise vivida pelas elites de Itabuna, que deveriam pensar na industrialização regional para minimizar os efeitos da crise do cacau.

O segundo aspecto diz respeito à relação pioneirismo e progresso, estabelecida pelo autor, na referida obra, e à evocação da figura do bandeirante paulista, associando-a ao do pioneiro itabunense. Nas palavras de Pereira Filho:

[...] o que é Itabuna, representada pela sua força social, econômica e política, todos sabem e todos conhecem pela posição que ocupa na colocação dos municípios brasileiros. Aos itabunenses poderíamos aplicar aqueles magníficos versos de Olavo Bilac, endereçados ao desbravador bandeirante: "cada passada tua era um caminho aberto, cada pouso mudado, uma nova conquista, teu pé, como de um deus, fecundava o deserto". ${ }^{42}$

Em estudo sobre os pioneiros da região cacaueira do sul da Bahia, com base na figura dos novos ricos de Ilhéus, que estabeleciam um contraponto com a aristocracia escravista açucareira, Mary Mahony ressalta que "a ênfase sobre desbravadores e produtores progressistas fez com que os cacauicultores e seus ancestrais parecessem mais com os heroicos bandeirantes e produtores progressistas de São Paulo do que com os abatidos aristocratas

42 PEREIRA FILHO, Carlos. Op., cit., p. 14. 
da indústria açucareira da Bahia" ${ }^{43}$. Nesse sentido, observamos que assim como os intelectuais da região estavam envolvidos em escrever uma história heroica para Ilhéus, nas décadas de 1920 e 1930, com base na figura dos progressistas novos ricos, também em Itabuna, na década de 1960, a elite política e intelectual empreendia esforços na escrituração de uma narrativa do pioneirismo progressista sergipano, no intuito de construir uma história vitoriosa para a cidade de Itabuna. Pereira Filho conclui: "Itabuna deve seu progresso e sua prosperidade aos seus próprios desbravadores". ${ }^{44}$

No rol dos "desbravadores" de Itabuna, comparados aos paulistas por Pereira Filho, estão as figuras de Firmino Alves, Militão Oliveira, Henrique Alves e Gileno Amado como "homens que descobriram e ajudaram a construir o município". Por conseguinte, todo itabunense deveria conhecê-los ${ }^{45}$. Os nomes citados por Pereira Filho representam os novos ricos de Itabuna. Eram, em sua maioria, correligionários de Antônio Pessoa e Misael Tavares, coronéis do cacau, que norteavam a política e a economia de Itabuna, em início do século XX, de quem descendia a elite política e intelectual da década de 1960, preocupada em escrever tal história.

Anteriormente a Terras de Itabuna, Pereira Filho escreveu Ilhéus, terra do cacau, analisado por Mary Mahony. Nota-se entre essas obras uma diferença significativa: de acordo com Mahony, na narrativa histórica de Ilhéus, o jornalista Carlos Pereira Filho é um opositor à ideia posta pela narrativa tradicional vigente à época, que contava a

43 MAHONY, Mary Ann. Op., cit., p. 765.

44 PEREIRA FILHO, Carlos. Op., cit., p. 16.

45 Idem, p. 20. 
história da lavoura cacaueira ligada ao trabalho dos pioneiros, ocultando, em contrapartida a utilização da mão de obra escrava. Em Ilhéus, terra do cacau, afirmou que a lavoura cacaueira teria nascido ao lado dos engenhos de açúcar ${ }^{46}$ da comarca, fazendo menção à presença do trabalho escravo na implantação de ambas as lavouras. Já em Terras de Itabuna, o autor reverencia o papel dos sergipanos como os precursores de uma cidade notável, representante do progresso no Estado da Bahia. Dessa forma, entendemos que o discurso narrativo de Terras de Itabuna representa um esforço de apresentar a cidade separada do passado de Ilhéus que, segundo Pereira Filho, teria edificado seus cacauais nas práticas arcaicas da antiga aristocracia. Nessa perspectiva, ao contrário de Ilhéus, onde o autor associou a história dos pioneiros do cacau à história da aristocracia escravocrata, Itabuna teria nascido, tão somente, pelo suor e trabalho dos seus pioneiros, os sergipanos.

Em Documentário Histórico Ilustrado de Itabuna, de 1968, José Dantas de Andrade escreve de forma épica, afirmando que "Itabuna foi uma índia, que Félix Severino encontrou no mato e entregou a seu sobrinho José Firmino Alves, o qual lhe soube dar boa criação, educação, instrução e beleza" ${ }^{\prime 4}$. A referida citação parece ser um exemplo pertinente do caráter progressista que envolvia a narrativa da memória de Itabuna. Novamente a narrativa da memória faz alusão à presença indígena nas origens de Itabuna, mas o faz de forma efêmera e transitória, pois a índia que era Itabuna, encontrada por Félix Severino de Oliveira, o sergipano, deixaria o estado selvagem para assumir "os

46 MAHONY, Mary Ann. Op., cit., p. 778.

47 ANDRADE, José Dantas de. Documentário Histórico Ilustrado de Itabuna. Itabuna: Gráfica Editora Itabuna, 1968, p. 18. 
modos da sociedade" por intermédio do seu fundador, Firmino Alves, também sergipano.

De acordo com os registros memorialistas, após a chegada e o estabelecimento de Félix Severino do Amor Divino à região, ele, aos poucos, levou seus familiares para lá também, dentre os quais o sobrinho José Firmino Alves que, por sua vez, se tornou uma das principais figuras políticas da região, aclamado como fundador de Itabuna. Firmino Alves representa, na memória coletiva oficial de Itabuna, o ícone do legado pioneiro da cidade. A identidade sergipana que se desejava criar estava ligada à figura de empreendedorismo e trabalho de Firmino Alves; dessa forma, estava sendo forjada uma identidade positiva, à qual os itabunenses deveriam sentir-se pertencentes, em meio aos desânimos e expectativas de restabelecimento da economia regional.

José Firmino Alves de Souza Freire, neto de Firmino Alves, também se fez presente no processo da escrita da história de Itabuna, durante as comemorações do seu cinquentenário. Seu discurso evoca as comemorações em homenagem ao centenário de nascimento de Firmino Alves, no contexto do cinquentenário de Itabuna, de forma que a história de Itabuna, e a dele, seu fundador, se intercruzam na memória da cidade. Segundo Freire, "ao completar 100 anos de seu nascimento [...], as autoridades e o povo de Itabuna, em colaboração com as autoridades dos Estados da Bahia e Sergipe e de vários municípios, lhe prestaram significativa homenagem, através de festas jamais assistidas nesta cidade" ${ }^{\prime 4}$. Portanto, na década anterior ao cinquentenário de Itabuna, foram empreendidos esforços,

48 FREIRE, José Alves de Souza. Firmino Alves: Fundador de Itabuna. Itabuna: Edições ITAGRAF, 1963, p. 22. 
por parte do governo municipal, bem como dos municípios vizinhos do governo dos estados da Bahia e de Sergipe, para os festejos do centenário de Firmino Alves.

Na perspectiva de Sandra Pesavento, "a identidade é uma construção simbólica de sentido, que organiza um sistema compreensivo a partir da ideia de pertencimento. A identidade é uma construção imaginária que produz a coesão social" ${ }^{49}$. Portanto, a identidade sergipana foi engendrada na década de 1960 através de um jogo simbólico e de representação no qual os sergipanos foram evocados, em detrimento de outros tantos atores presentes na história das origens da cidade que, por sua vez, foram invisibilizados pela narrativa da memória. $\mathrm{O}$ poder de tal construção simbólica reside no fato de que ela mantém uma memória coletiva coesa. Ainda que haja espaço para outras memórias coletivas na sociedade itabunense, é importante notar que existe uma memória coletiva oficial, cultuada pela prefeitura, por exemplo, que legitima o pioneirismo e a centralidade dos sergipanos.

A memória coletiva estava sendo engendrada e sistematizada através da narrativa memorialista, mas também,por meio de outros recursos discursivos, como era o caso do jornal Diário de Itabuna, no qual circulava um ponto de vista da história associado aos interesses da elite política e intelectual da região, como já demonstramos no início do texto. Uma matéria de página inteira do jornal, no mês no aniversário da cidade, sintetiza na figura de Firmino Alves a relação entre o pioneiro e a cidade do progresso, bem como, mais uma vez, imbrica a história de origem à memória sergipana:

49 PESAVENTO, Sandra Jatahy. Op., cit., p. 89. 
A propósito das festas do cinquentenário de Itabuna, destas colunas lembramos de uma feita à Comissão dos festejos a necessidade de um convite oficial ao Governo e ao poder Legislativo Sergipano. Nos reportamos ao brilho dado às festas do centenário do nascimento de Firmino Alves, fundador da cidade, quando Sergipe mandou uma embaixada composta de deputados e jornalistas. Com ela veio também a bandeira sergipana pertencente ao Instituto Histórico de Aracajú, a qual, por solicitação de Itabuna foi concedida para as festividades por gentileza de seu Presidente e fez aqui parte no desfile, carregada por elementos representativos da colônia sergipana. Não é demais pois, lembrarmos mais uma vez a conveniência do convite, porque nessa festa Sergipe tem o seu quinhão muito importante. O sergipano foi um desbravador deste grande Município que é hoje Itabuna, orgulho da Bahia. Participou das lutas e canseiras, sem o que não estaríamos hoje, orgulhosos e satisfeitos comemorando uma data que nos é rara [...], com o exemplo dado pela bravura e destemor dos pioneiros que vieram do Estado vizinho trabalhar para nossa grandeza. ${ }^{50}$

Na matéria citada, o colunista remete os festejos do cinquentenário da cidade de Itabuna ao festejo do centenário de nascimento de Firmino Alves, ocorrido em 1953. Ressalta a presença oficial do Estado de Sergipe nas comemorações daquela ocasião, e evidencia a necessidade de remeter ao governo sergipano um convite oficial, para que Sergipe participasse do cinquentenário de Itabuna.

50 CEDOC; Diário de Itabuna, Sexta-feira, $1^{\circ}$ de julho de 1960, Ano III, $\mathrm{n}^{\mathrm{o}} 730$, p. 1 
Portanto, era na consolidação da identidade pioneira e em sua trajetória histórica que residiam a eficácia da memória coletiva da cidade, haja vista que "a batalha pelo controle político da região sempre esteve intimamente ligada à luta pelo controle da história". ${ }^{51}$

Desde a década de 1930, os trabalhadores rurais se mostravam insatisfeitos, e os ânimos se exaltavam, tanto no campo quanto na cidade, em virtude das dificuldades econômicas e demandas sociais não atendidas. Depois de sucessivas crises externas e internas pelas quais passou a economia regional baseada na monocultura do cacau, se estabeleceu um alto índice de desemprego na região sul da Bahia. Naquele contexto, os trabalhadores voltaram a se organizar sindicalmente, sob a liderança do Partido Comunista Brasileiro (PCB). Em 1957, o Ministério do Trabalho brasileiro reconheceu oficialmente a União dos Trabalhadores Rurais de Itabuna e Ilhéus. Vale observar que aquela era a única organização rural da Bahia a receber tal reconhecimento ${ }^{52}$. Como desdobramento desses acontecimentos, no início da década de 1960, as ligas camponesas estavam ativamente reivindicando uma reforma agrária radical". ${ }^{53}$

Foi no bojo das dificuldades econômicas e sociais nas quais estava imersa a região cacaueira que a elite política e intelectual de Itabuna se ocupou em escrever a história dos que trabalharam e venceram, de quem eles haviam herdado as suas riquezas. No contexto de insatisfação dos trabalhadores rurais era pertinente contar a história de origem pela perspectiva do homem simples da roça, mi-

51 MAHONY, Mary Ann. Op., cit., p. 739.

52 Idem, p. 774.

53 Idem, ibidem. 
grante pobre que, de forma destemida, derrubou a mata, plantou o cacau, trabalhou muito e venceu. Nas palavras de Pereira Filho:

Por muitos anos esses homens trabalharam anonimamente, humildemente, bravamente, derrubando matas, fazendo roças, plantando cacau, acumulando riquezas. Verdadeiros heróis das selvas, isolados do mundo, da civilização, adoeciam e morriam sem remédio, sem conforto, sem assistência $[\ldots]$, a riqueza daquela terra $[. .$.$] , se havia$ construído, com sacrifício, com martírio de uma geração, com trabalho audacioso ${ }^{54}$.

Contudo, a escolha por escrever a narrativa histórica de Itabuna pelo viés do pioneirismo sergipano demandava invisibilizar outros atores daquele processo. Nessa empreitada, os índios aldeados de Ferradas, que atuaram indireta e diretamente na lavoura do cacau, possibilitaram o acesso de colonos à região, bem como empregaram a sua mão de obra nas roças de cacau, durante o século XIX, foram propositalmente invisibilizados na história que se desejava criar. Nesse sentido, vale citar novamente Pesavento, para quem, na construção da memória, o esquecer está tão presente quanto o lembrar ${ }^{55}$. Também Paul Ricoeur frisa que "o esquecimento pode estar tão estreitamente confundido com a memória que pode ser considerado como uma de suas condições". ${ }^{56}$

54 PEREIRA FILHO, Carlos. Op., cit., p. 30-31.

55 PESAVENTO, Sandra Jatahy. Op., cit., p. 95.

56 RICOEUR, Paul. A memória, a história, o esquecimento. Campinas, São Paulo: Editora da Unicamp, 2007, p. 435. 


\subsection{O jogo de lembrar e esquecer: o afastamento de Ferradas na escrita da memória de Itabuna}

Paul Ricoeur, em A memória, a história, o esquecimento, tece algumas importantes observações acerca da relação entre memória e esquecimento, que são norteadoras para as reflexões propostas neste tópico do capítulo. Desse modo, elencaremos algumas de suas contribuições a partir de duas categorias da memória que ele denomina de "memória impedida" e "memória manipulada".

Paul Ricoeur trabalha com a categoria de "memória impedida" para tratar do esquecimento da memória. Para tanto, ele estabelece um diálogo direto com a psicanálise. Ressalta a tese freudiana de que "o paciente repete, ao invés de se lembrar. Ao invés de: a repetição vale esquecimento" ${ }^{\prime 57}$. Segundo Ricoeur, a primeira lição dada pelos psicanalistas é a de que "o trauma permanece mesmo quando inacessível, indisponível. No seu lugar surgem fenômenos de substituição, sintomas que mascaram o retorno do recalcado de modos diversos ${ }^{\prime 58}$.

Para Ricoeur, "o esquecimento de impressões e de acontecimentos vivenciados [...] e o esquecimento de projetos que equivalem à omissão, à negligência seletiva, revelam um lado ardiloso do inconsciente colocado em postura defensiva"; ;9 ele ressalta que as manifestações individuais e coletivas do esquecimento estão misturadas de forma inextricável ${ }^{60}$, e pontua que é na memória coletiva que o esquecimento produz os efeitos mais nocivos.

57 RICOEUR, Paul. Op., cit., p. 452.

58 Idem, p. 453.

59 Idem, p. 454.

60 Idem, p. 451. 
Nas palavras do autor, "esquecimento, lembranças encobridoras, atos falhos assumem, na memória coletiva, proporções gigantescas, que apenas a história e, mais precisamente, a história da memória é capaz de trazer à luz" ${ }^{61}$

A segunda categoria da memória trabalhada por Ricoeur é a da "memória manipulada". Segundo ele, a manipulação da memória se dá por via ideológica, pela mediação da narrativa ${ }^{62}$. O autor ressalta que é impossível lembrar tudo, assim como é impossível narrar tudo. Aqui, esquecimento e narrativa da memória caminham juntos. E em se tratando da ideologização da memória, Ricoeur frisa ser ela possibilitada pela variação do trabalho da configuração narrativa, ou seja, pelo modo como o narrador irá compor ou delinear a sua narrativa, pois "pode-se sempre narrar de outro modo, suprimindo, deslocando ênfases, refigurando diferentemente os protagonistas da ação assim como os contornos dela". ${ }^{63}$ É nesse jogo do esquecimento da memória que tentaremos identificar os meandros da invisibilização dos índios de Ferradas. À medida que se opera, na narrativa, o afastamento, o silenciamento do núcleo indígena (Ferradas) da história, os índios, sucessivamente, são afastados junto com a aldeia.

A construção da memória pioneira de Ilhéus, estudada por Mahony, tinha por finalidade esconder o passado escravocrata e negar a atuação da mão de obra escrava na lavoura do cacau. A escrita da memória de Itabuna, embora estivesse em sintonia com os aspectos mais gerais da escrita da memória regional, guardava uma peculiaridade. Diferentemente da de Ilhéus quatrocentona, na narrativa

61 RICOEUR, Paul. Op., cit., p. 455.

62 Idem, Ibidem.

63 Ibidem. 
memorialista da década de 1960, a jovem Itabuna se sentia livre do fardo de um passado escravocrata, muito embora a sua lavoura de cacau também tenha sido construída com braços escravos e mão de obra compulsória indígena, como veremos, mais adiante, neste livro.

A particularidade presente na narrativa de Itabuna com relação à narrativa de Ilhéus residia no esforço empreendido pela obra memorialista itabunense, para construir uma ideia da ausência indígena no delineamento da história de origem de Itabuna. Para Sandra Pesavento, "as identidades podem dar conta dos múltiplos recortes sociais, sendo étnicas, raciais, religiosas, etárias, de gênero, de posição social, de classe ou de renda, ou ainda profissionais" ${ }^{\prime 64}$. Segundo essa perspectiva, a narrativa memorialista de Itabuna se pautou, dentre outros, num recorte de posição social, tendo em vista que as narrativas apresentadas estão voltadas a estabelecer o lugar social dos sergipanos e de seus descendentes na história de Itabuna e, em consequência disso, a escrita da memória está marcada por um viés de exclusão étnica, pois para que a identidade sergipana fosse construída era necessário que os índios fossem invisibilizados.

Lembrando as reflexões de Ricoeur, podemos inferir que a narrativa memorialista de Itabuna, através da manipulação da memória, suprime os índios da narrativa histórica da cidade, enfatiza a presença e atuação pioneira, para assim, dar os contornos desejados pela história que se quer narrar. Também Sandra Pesavento observa que, na construção da memória, "as pessoas são ensinadas a lembrar e esquecer, fazendo com que determinados acontecimentos não sejam considerados importantes ou mesmo

64 PESAVENTO, Sandra Jatahy. Op., cit., p. 91. 
que não tenham acontecido"65; nesse jogo de lembrar e esquecer, o objetivo é a construção de uma memória coletiva coesa que, por sua vez, legitime a identidade sergipana de Itabuna como sendo a memória oficial da cidade.

A elite de Itabuna era, em grande parte descendente de negros e índios, como era o caso de Firmino Alves: um "pardo de Sergipe, que se estabeleceu na região em meados do século XIX e se casou com uma mulher de ascendência indígena". ${ }^{66}$ Contudo, construiu uma memória da qual eles são excluídos, fazendo emergir apenas o passado sergipano. Foi construído para Itabuna um histórico étnico de negação da presença indígena. Eles estavam lá, num passado remoto, e desapareceram à medida que entraram em cena os sergipanos. A narrativa da memória de Itabuna, de 1960, estava toda ela norteada por um discurso progressista, que colocava Itabuna num patamar elevado na composição dos municípios da Bahia. Essa narrativa, em contrapartida, engendrava a ideia da presença indígena em Ferradas em um passado distante, porque naquele contexto, o da década de 1960, a imagem que se desejava criar para a origem da cidade, de civilização e progresso, não comportava o reconhecimento da presença indígena em suas origens, pois os índios representavam a ausência de civilização e obstáculo ao progresso da região. Esses são os argumentos que tentaremos tecer, a partir daqui, acerca do afastamento de Ferradas e dos índios, sobre a memória coletiva oficial de Itabuna.

A leitura feita sobre as populações indígenas do sul da Bahia na escrita memorialista era extremamente pejorativa. Os índios eram descritos como os selvagens

65 PESAVENTO, Sandra Jatahy. Op., cit., p. 96.

66 MAHONY, Mary Ann. Op., cit., p. 746. 
que, percebendo a inutilidade de suas flechas diante das armas de fogo dos colonizadores, se aprofundavam nas matas. É dessa maneira, por exemplo, que José Dantas de Andrade narra a situação do contato entre índios e não índios naquela parte do sul da Bahia. Ele assevera que nos encontros "entre índios e desbravadores, a vitória ficava sempre com os segundos, obrigando a que os silvícolas, compreendendo a inutilidade de suas flechas contra as espingardas, bacamartes e mosquetões, fossem se aprofundando cada vez mais nas matas, cedendo terreno ao avanço dos brancos" ${ }^{67}$

Assim como na escrita da memória, também na literatura regional encontramos a descrição pejorativa com relação às populações indígenas do sul da Bahia. Nessa perspectiva, dentre outras obras, se destaca Corpo Vivo, de Adonias Filho, publicado naquela mesma, década de 1960. Adonias Filho era um importante romancista da região e certamente tinha os intelectuais de Itabuna como seus leitores.

Corpo Vivo, de 1962, trata da violência e expropriação das terras dos pequenos agricultores por parte dos grandes produtores de cacau. $\mathrm{O}$ enredo narra a vingança de Cajango, um mestiço que, após o assassinato da família, é criado pelo tio índio, Inurí, "que lhe incutiu o ódio e a vingança e o transformou num animal selvagem, impedindo que ele se tornasse homem" ${ }^{\prime 68}$. Na perspectiva de Adonias Filho, Inurí, o índio representante das populações indígenas do sul da Bahia, era caracterizado como fera, cuja estratégia de reação aos colonizadores era a vingança. A personagem denota o caráter negativo empregado pelo autor acerca dos índios habitantes da região. Era dessa ideia que

67 ANDRADE, José Dantas de. Op., cit., p. 21.

68 DANTAS, Robson Norberto. Op., cit., p. 149. 
compartilhavam os memorialistas que se envolveram em escrever a história de Itabuna, naquela mesma ocasião.

A narrativa memorialista de Itabuna, em lugar de engendrar um passado "selvagem" e, portanto, fracassado, objetivava construir uma ideia progressista acerca da atuação dos sergipanos de Tabocas. Para tanto, estabeleceu um distanciamento entre Tabocas e Ferradas na memória coletiva oficial de Itabuna. Ferradas representava a presença e atuação indígena, e isso era uma parte da história que se desejava esquecer ou, pelo menos, deveria ser guardada num lugar distante, nessa memória oficial.

Em Terras de Itabuna, Pereira Filho observa que "em cinquenta anos o que realizou o povo itabunense impressiona e maravilha [...]. Cidade que tem uma elite intelectual, que tem bons jornais, estações de rádios, bons colégios" $^{\prime 69}$, ou seja, era a cidade pródiga e civilizada, na qual não cabia a primitiva Ferradas, lugar de índios. Pereira Filho ressalta que "muito distante está a época em que, em Ferradas, Frei Ludovico de Liorne prestava socorro a alguns índios desamparados ${ }^{\prime 70}$. Na sua narrativa de decadência de Ferradas, ele continua:

Como andava o arraial em decadência! Ferradas, que em 1856 possuía cacau, café, que se fundou antes de Tabocas e que teve visitas ilustres, como a de Martius, de Maximiliano e daquele Guilherme Frederico, Barão Von Den Bussche, estava parada... Parou como vila, acabaria como simples arraial ou mesmo como uma rua comprida, acompanhando o rio Cachoeira ${ }^{71}$.

69 PEREIRA FILHO, Carlos. Op., cit., p. 15

70 Idem, ibidem.

71 Idem, p. 27. 
Enquanto Tabocas era apontada como o protótipo de riqueza, Ferradas assinava sua sentença de morte com o tempo, pois a ela estavam fadados o fracasso, a falência. Era a Ferradas de frei Ludovico e dos seus índios aldeados: "Ferradas teve dias gloriosos [...]. Mas tudo passou. Frei Ludovico, velho e enfermo, foi morrer no seu convento, em Salvador".$^{72}$ Com sua morte, parece também que morre Ferradas, e os índios desaparecem, para dar lugar ao progresso da região, pois, ressaltava-se que "enquanto os índios recuavam para as matas, levas e levas de desbravadores se apoderavam das terras boas para o cacau". ${ }^{73}$

Portanto, a narrativa de origem, gestada na década de 1960, não associou à imagem de Itabuna um passado indígena. Ao contrário disso, ao forjar a imagem do pioneiro sergipano, a escrita memorialista escamoteia a importância estratégica de Ferradas e com isso invisibiliza os índios na memória coletiva oficial.

Esse era um distanciamento historicamente construído, que demarcava diferenças étnicas, culturais, sociais e políticas entre o lugar dos índios e o lugar dos outros. A memória coletiva oficial de Itabuna atinge uma coesão quando faz várias exclusões, em particular a dos índios, e pela sua força mitológica de atualização e formalização dos símbolos e representação identitária, com se verá a seguir.

72 PEREIRA FILHO, Carlos. Op., cit., p. 26.

73 Idem, ibidem. 


\subsection{Algumas reflexões acerca da atualização do mito pioneiro}

Em estudo sobre os símbolos de identidade social do centro da cidade de Itabuna, a professora Lurdes Bertol Rocha aponta as principais edificações públicas que, segundo ela, compõem a memória da cidade. Entendemos, no entanto, que elas não compõem naturalmente a memória, mas são símbolos da construção da memória coletiva, geradora do mito pioneiro. Realmente, algumas dessas edificações se constituem de importantes símbolos da presença "pioneira" na memória coletiva oficial da cidade.

Dentre os símbolos constitutivos da identidade sergipana nos espaços do centro da cidade de Itabuna, destacamos: O Edifício Comendador Firmino Alves, centro de decisões com relação à lavoura do cacau nas décadas de 1950 e 1960; O Museu Casa Verde, que Rocha destaca por sua importância cultural para Itabuna, visto que retrataria a vida do coronelismo, "onde foram reconstruídos os costumes e a época de uma das fases mais importantes da história regional". ${ }^{74} \mathrm{O}$ então museu Casa Verde foi, outrora, residência do coronel Henrique Alves; Praça Santo Antônio, local em que, no ano de 1944, foi inaugurado, no centro da praça, um monumento em homenagem a Firmino Alves. Além desses espaços, dentre tantos pontuados pela autora, poderíamos apontar, ainda, inúmeras ruas, escolas e outros espaços públicos que lembram os migrantes de Sergipe, que ali chegaram a partir da segunda metade do século XIX e seus descendentes.

Os símbolos edificados no centro de Itabuna explicitam o exercício da memória, no sentido de fazer lembrar o lugar

74 ROCHA, Lurdes Bertol. O centro da cidade de Itabuna: trajetórias, signos e significados. Ilhéus: Editus, 2003, p. 118. 
das elites da cidade com seus nomes e feitos. Pelo exercício da representação identitária, a versão das elites da cidade é apresentada à memória coletiva como a própria história local. Concomitantemente, essas versões são repetidas, quando não pela preservação de monumentos, pela narrativa literária ou, ainda, por trabalhos acadêmicos que estudam a história regional. A exemplo disso, Rocha destacou que

\begin{abstract}
apenas $1,8 \%$ dos entrevistados [...] citam o monumento localizado na Praça Santo Antônio [...] como signos que lhes digam alguma coisa [...]. Isto parece significar o total desconhecimento da história da cidade e, naturalmente, o não compromisso em relação à manutenção de sua memória ${ }^{75}$.
\end{abstract}

A observação da autora, de que o desconhecimento dos monumentos existentes no centro da cidade, por parte da maioria dos seus moradores, significa descompromisso com a manutenção da memória, merece uma pergunta, ainda que óbvia: A que memória se refere? Ela se refere a uma memória específica; a memória oficial dos sergipanos, especialmente a figura de Firmino Alves, como podemos notar na referência feita a alguns monumentos do centro de Itabuna, exemplificados acima, ligados à figura de Firmino Alves e a seus pares. Dessa forma, o trabalho de Rocha reflete a permanência da versão das elites da década de 1960, em trabalhos mais recentes, acerca da trajetória histórica de Itabuna.

Os diversos trabalhos memorialistas, e, também, os acadêmicos, técnicos e literários publicados ao longo do século $X X$, tinham a preocupação de engendrar uma história para a região do cacau, e funcionaram, e, em

75 Idem, p. 125. 
certa medida, ainda funcionam como controle da história regional, enquadrando-a como a história dos pioneiros do cacau. Aqui, vale citar Mahony. Ela aponta que "o poder da mitologia da história do cacau reside no fato de que ela não é imposta, pois se apresenta espontaneamente [...] nos vários estudos [...] publicados e repetidos indefinidamente $[\ldots .$.$] ao longo de todo o século X X^{\prime \prime 76}$.

Também a obra do memorialista Adelino Kfoury Silveira, publicada em 2002 e recebida com entusiasmo pela "sociedade itabunense", se constitui em bom exemplo de atualização da memória oficial de Itabuna. O autor de Itabuna, minha terra atuou como membro do Instituto Geográfico e Histórico da Bahia, foi sócio titular da Associação Brasileira de Relações Públicas e sócio efetivo da Associação Baiana de Imprensa. Vale ressaltar que foi proprietário de um considerável acervo histórico e atuante sobre a vida pública de Itabuna. Falecido recentemente, ele era reconhecido social e politicamente como importante guardião da história da cidade.

Em Itabuna, minha terra, Kfoury critica a visão do coronel do cacau posta pelas literaturas amadiana e adoniana, acusadas de ter construído um estereótipo de ambição e desonestidade para os homens pobres enriquecidos com o cacau. Ele ressalta a necessidade de não se perder de vista que, antes de considerar o mandonismo, com base no poder econômico e político dos coronéis da região, não se podia esquecer que eles foram os pioneiros, trabalharam e, portanto, naturalmente construíram o lugar econômico, político e social que ocupavam. Contudo, o mais interessante é notar que o discurso de Kfoury tenta retirar o peso negativo, que desgasta a figura dos coronéis e enaltece a

76 MAHONY, Mary Ann. Op., cit., p. 789. 
crença de que, de fato, eles representavam o passado árduo de trabalho e construção da riqueza regional:

Qual seria, pois, a figura real do coronel do cacau? Achamos ser de justiça entender que ele foi acima de tudo um desbravador [...]. Só mesmo a ação do tempo, o correr dos anos, fez com que esse exemplo de tenacidade gerasse o respeito e a obediência dos habitantes da região. Daí, num processo natural, foram chegando às suas mãos a riqueza e a força política. ${ }^{77}$

O autor segue a narrativa estabelecendo um distanciamento entre os "novos ricos" e a antiga aristocracia dos engenhos, ao dizer que havia diferenças "a se considerar e estabelecer entre o nosso coronel e os senhores de engenho, é que ele vivia em casebres no âmago da floresta, dormindo em rede ou cama de esteira".${ }^{78}$ Dessa maneira, Kfoury reforça o discurso dos memorialistas da década de 1960, de que a riqueza da elite itabunense era herança dos legítimos construtores de Itabuna.

Para Sandra Pesavento, "a elaboração dos mitos de origens vai ao encontro das identidades nacionais, compondo conjuntos de referência para as raízes de um po-

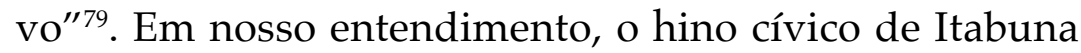
foi evocado como um importante símbolo constituidor dessas identidades. Portanto, além da atualização do mito pioneiro, na narrativa memorialista, a emergência de um hino oficial para Itabuna no contexto do centenário compõe, de forma eficiente, a naturalização da versão

77 SILVEIRA, Adelino Kfoury. Itabuna, minha terra. Itabuna: Gráfica Santa Helena, 2002, p. 14-15.

78 Idem, p. 15.

79 PESAVENTO, Sandra Jatahy. Op., cit., p. 91. 
discursiva construída para o cinquentenário da cidade, em 1960.

Em 2010, às vésperas de comemorar os cem anos de Itabuna, a Fundação Itabunense de Cultura e Cidadania (FICC) lançou o concurso para eleição do hino oficial de Itabuna, já que o hino conhecido como o hino da cidade, até então, não seria oficial por não possuir nenhum registro de sua oficialização junto à Câmara Municipal da cidade. O concurso provocou verdadeiro rebuliço: os "guardiães da memória da cidade" consideraram a atitude da FICC um ultraje e descaso à história de Itabuna. Não foram poucas as manifestações de protesto em rádios, blogs e sites que circulavam na cidade. No entanto, em detrimento das reivindicações empreendidas, o concurso foi realizado e eleito o novo hino de Itabuna, a ser cantado nas cerimônias formais e distribuído pela Secretaria de Educação para as escolas municipais, no intuito de que nos festejos do centenário, os estudantes estivessem familiarizados com o hino da cidade. Contudo, em meio às contendas geradas pelo concurso para escolha de um novo hino, nos parece que houve um pacto de conformação na escolha do mesmo com relação ao antigo. No novo hino, com exceção de algumas modificações (a mais importante foi a inserção do cacau, pois o antigo hino não o mencionava), permaneciam os elementos centrais contidos no hino antigo: bravura e atuação pioneira, bem como alusão à ideia de progresso.

Dentre as versões submetidas à votação popular, em 2010, a versão escolhida pela maioria dos votantes, foi o hino de autoria de Carlos Correia Oliveira, com 39\% do total dos votos, que não passava de uma leitura um pouco atualizada do antigo hino de Itabuna. Na cerimônia de oficialização da eleição, Carlos Correia Oliveira proferiu, às autoridades municipais, as seguintes palavras: “Não fui 
eu quem venceu, mas sim, o povo de Itabuna que terá sua história perpetuada". ${ }^{80}$

Assim como no hino antigo, o novo trazia simbolicamente dois aspectos principais da construção da identidade itabunense: a figura do pioneiro e a ideia de uma história progressista:

Lá na mata, o ouro fruto,

O seu brilho atraiu

Homens bravos, corajosos,

A natureza... O desafio!

Com o machado, o homem na mata

Ressoa o grito voraz da vitória!

Tabocas! Tabocas! Tabocas...

Itabuna tu és agora! ${ }^{81}$

O hino, como era de se esperar, deixava em evidência a atualização de uma memória coletiva da cidade, na qual não existia espaço para outros atores que não fossem os ditos pioneiros da região. Eram apenas eles, a mata e o desafio de vencê-la. A ideia progressista gestada pela narrativa da década de 1960, de que ao futuro da cidade estava reservado o progresso industrial, foi atenuada, visto que, como já refletimos, aquela narrativa soava como uma alternativa para pacificar os ânimos e insatisfações diante do fracasso do cacau, naquele momento, o que já não atendia à realidade de 2010 . No atual hino, a referência ao papel da indústria na cidade aparece apenas em uma frase: "No comércio, na indústria... Sua força!". Quando

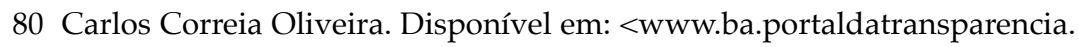
com.br>. Acesso em: 9 dez. 2014, às 22: 57.

81 Autoria de Carlos Correia Oliveira. Divulgação oficial da eleição do Hino de Itabuna: Diário Oficial do Município: 4 de junho de 2010, ano II, $\mathrm{n}^{\circ}$ 365. Disponível em: $<$ www.ba.portaldatransparencia.com.br $>$. Acesso em: 9 dez. 2014, às 23:40. 
na antiga versão, o apelo progressista com ênfase na indústria ressaltava:

[...] Seu progresso bem traduz

O que em palavra diria

Oh! Rainha da Bahia.

Sua fonte de riqueza

No Estado é sem rival

E em muito breve terá

Inteirando sua beleza

Grande parque industrial. ${ }^{82}$

Desse modo, diante do prometido "parque industrial" que não chegou, a ênfase dada ao aspecto industrial para definir a potência econômica de Itabuna foi retirada da versão atual do hino. Em contrapartida, foi reforçada a atuação dos "pioneiros". Em nosso entender, essa história de origem atinge uma coesão na memória coletiva, à medida que ganha significado amplo e formal na trajetória histórica da cidade.

$\mathrm{Na}$ comparação entre os dois hinos, um aspecto que consideramos dos mais interessantes é o seguinte: o primeiro hino não faz referência alguma ao cacau e prioriza a vocação industrial da cidade; já a versão atual atenua a ideia de progresso industrial para Itabuna e coloca no centro da letra do hino o cacau:

Lá na mata, o ouro fruto,

O seu brilho atraiu

Homens bravos, corajosos,

A natureza... O desafio!

82 Autoria de Nicolau Midlej. Blog Itabuna Centenária. Disponível em: <cemanosdeitabuna.ning.com>. Acesso em: 10 dez. 2014, às 00:09. 
$[\ldots]$

O fruto ouro nos olhos, na alma!

Do Cachoeira, a cidade se expandindo!

Em 2010, quando se deu a comemoração do centenário de Itabuna, parecia importante falar do cacau, falar dos ditos pioneiros e seu papel de vanguarda. Essa parecia ser a história que se desejava incutir nos novos e perpetuar através da memória coletiva oficial. Além disso, a Itabuna de 2010 era uma cidade que já não vivia do cacau, sua economia girava, principalmente, em torno da oferta de serviços; do mercado terceirizado e do comércio, que passaram a atender os pequenos municípios vizinhos. Ela não carregava mais o peso que representava o fracasso do cacau para uma região monocultora, como o era na década de 1960. Podia-se falar novamente do cacau sem constrangimento social para a sua "antiga" elite.

Analisando a produção memorialista amparada em uma série de aparatos de legitimação da sua narrativa, propusemos, até aqui, a reflexão de um duplo movimento da escrita memorialista: lembrar os sergipanos e esquecer os índios, na construção do que chamamos de uma memória coletiva oficial sobre a fundação de Itabuna e sua história. Nos próximos capítulos, tentaremos analisar a história de parte do sul da Bahia, durante o século XIX, hoje conhecida como Itabuna, por outros vieses, que possibilitem acolher e pensar outras variantes e outros atores dessa história.

Como frisamos no início deste capítulo, nossa pretensão não foi travar uma batalha entre mito e história; ao contrário, buscamos demonstrar como a história se transformou em mito, como o mito se entranhou na trajetória política e intelectual da cidade. Nesses últimos parágrafos, contudo, consideramos pertinente elencar algumas observações acerca da narrativa histórica, que é o lugar de fala do 
presente estudo e, assim, acentuar o nosso posicionamento teórico-metodológico delimitado nos capítulos seguintes.

Carlo Ginzburg observa que os historiadores, há algumas décadas, se ocuparam em discutir muito sobre "os ritmos da história", mas pouco ou nada sobre os "ritmos da narrativa histórica" 83 , o que suscitou infindáveis críticas internas e externas da disciplina. Nesse sentido, além do próprio Ginzburg, outros estudiosos, como Paul Ricoeur, procuraram não apenas encontrar respostas às críticas recebidas, mas, principalmente, pensar o caráter particular da narrativa do conhecimento histórico.

Paul Ricoeur, enfrentando o tema da narrativa histórica em face da memória, propõe analisar o trabalho da operação historiográfica em três fases: a fase documental, a fase explicativa/compreensiva e a fase reconstrutiva. De acordo com ele, é na fase reconstrutiva que se tem "a intenção de representar em verdade as coisas passadas, pela qual se define em face da memória o projeto cognitivo e prático da história tal como a escrevem os historiadores profissionais" ${ }^{84}$. Em "representação e narração", o autor problematiza: que diferença separa a história e a ficção, se ambas narram? ${ }^{85} \mathrm{~A}$ resposta não é simples e muitos profissionais da história, da filosofia e da literatura se envolveram neste debate após os acirramentos gestados a partir da "virada linguística", em meados do século XX. Para Ricoeur, uma das saídas parece estar na compreensão do que sejam representação e acontecimento.

Novamente, outro questionamento: "Mas o que vem a ser um acontecimento depurado de qualquer conexão

83 GINZBURG, Carlo. O fio e os rastros: verdadeiro, falso, fictício. São Paulo: Companhia das Letras, 2007, p. 321.

84 RICOEUR, Paul. Op., cit., p. 147.

85 Idem, p. 253. 
narrativa?" 86 Ele responde: não há uma ligação direta entre a forma narrativa e o acontecimento tal como de fato foi produzido. Para o autor, a ligação entre narrativa e acontecimento se dá de forma indireta, através da explicação e "aquém desta, através da fase documental, que remete, por sua vez, ao testemunho e ao crédito dado à palavra alheia" ${ }^{87}$.

$\mathrm{O}$ acontecimento é o referente da representação do passado operada pela narrativa historiográfica. Paul Ricoeur lembra que "foi da teoria literária que veio a contestação em nome da disjunção entre a estrutura interna do texto e o real extratextual [...], é o modelo bipolar significante-significado, com exclusão do referente" ${ }^{88}$ Ricoeur frisa ser o efeito dessa assertiva literária devastadora para a narrativa da história, cuja diferença da narrativa literária ou ficcional se baseia na categoria referencial que a perpassa ${ }^{89}$. Sendo assim, não se tem a pretensão de apreender o passado na narrativa da história. Contudo, diferentemente do escritor ficcional, o historiador não trabalha apenas com a estrutura interna do texto, mas opera conjuntamente com a estrutura interna e com o real extratextual, pois

Diferentemente do pacto entre um autor e um leitor de ficção que se baseia na dupla convenção de suspender a expectativa de qualquer descrição de um real extralinguístico e, em contrapartida, reter o interesse do leitor, o autor e o leitor de um texto histórico convencionam que se tratará de situações, acontecimentos, encadeamentos, persona-

86 RICOEUR, Paul. Op., cit., p. 254.

87 Idem, p. 256.

88 Idem, p. 259.

89 Idem, ibidem. 
gens que existiram realmente anteriormente, isto é, antes que tenham sido relatados ${ }^{90}$.

Esforçamo-nos, até aqui, no sentido de tecer algumas reflexões consideradas importantes acerca da narrativa da memória de Itabuna da década de 1960, com um duplo olhar: perceber a construção do mito sergipano e o processo de invisibilização indígena empreendido naquela narrativa. Gostaríamos de frisar que, na história daquela parte do sul da Bahia, hoje conhecida como Itabuna, nem tudo era sergipano. Nessa direção, tentaremos demonstrar, a seguir, a atuação indígena na história da colonização da Cachoeira de Itabuna e na de Ferradas, ao longo do século XIX.

90 RICOEUR, Paul. Op., cit., p. 289. 
CAPÍTULO II 


\section{O ALDEAMENTO DE FERRADAS E A OCUPAÇÁO TERRITORIAL DE CACHOEIRA DE ITABUNA}

O aldeamento São Pedro de Alcântara, instalado na região sul da Bahia, em início do século XIX, também denominado, na documentação, como aldeamento de Ferradas, aparece descrito ora como freguesia, ora como vila e ora como aldeia por todo o tempo de vigência. Esse modo confuso de definir a categoria administrativa do estabelecimento se vincula ao próprio contexto de sua fundação e permanência. A fundação do aldeamento São Pedro de Alcântara compreende o final do período colonial, no qual se criam as vilas ${ }^{1}$ e freguesias ${ }^{2}$ nos antigos aldeamentos da capitania e posterior comarca de Ilhéus, e se estende à administração política imperial.

Contudo, a documentação analisada não fornece indícios para caracterizarmos aquele estabelecimento como vila, pois, segundo Marcis, a instituição de vilas "exigia o

1 Ver MARCIS, Teresinha. A integração dos índios como súditos do rei de Portugal: uma análise do projeto, dos autores e da implantação na Capitania de Ilhéus, 1758-1822. Tese de doutorado. Universidade Federal da Bahia. Salvador, 2013, p. 196: Segundo a autora, em 1759, o ouvidor Freire de Veras seguiu para a Capitania de Ilhéus a fim de realizar trabalhos de reformas nos aldeamentos, que compreendiam a instalação das vilas.

2 Cf. MARCIS, Teresinha. Idem, p. 218: O mesmo ouvidor Freire Luís de Veras havia sido responsável por redefinir as freguesias de Ilhéus nos moldes do arcebispado baiano, após a expulsão dos jesuítas. 
cumprimento de um ritual de demonstração da presença real, um aparato da administração da justiça e princípios que formalizavam os laços de fidelidade com o monarca" ${ }^{\prime 3}$. Também não existem indícios de que fosse efetivamente uma freguesia, "menor jurisdição eclesiástica, geralmente equivalente à civil da povoação ou vila" ${ }^{4}$. Neste trabalho, analisaremos o estabelecimento de Ferradas na sua dimensão de aldeia ou aldeamento, categoria administrativa da política indigenista colonial e imperial.

$\mathrm{Na}$ carta enviada pelo desembargador e ouvidor da comarca de Ilhéus ao Secretário de Estado da Marinha e Ultramar, Antônio de Araújo Azevedo, de 24 de maio de 1814, Balthazar da Silva Lisboa relatava a transferência dos índios do Almada para a região do rio Cachoeira ${ }^{5}$, onde funcionaria, a partir de então, o aldeamento São Pedro de Alcântara ou aldeamento de Ferradas.

Na correspondência, o ouvidor notificou o feito como se fosse uma vitória da civilização representada pela Coroa. Em homenagem ao príncipe regente, deu à nova povoação o nome de São Pedro de Alcântara, marcando a sua fundação para agosto, mês do aniversário do homenageado ${ }^{6}$.

Antônio Guerreiro de Freitas e Maria Hilda Baqueiro Paraíso, sob a ótica dos acontecimentos coloniais no Brasil em início do século XIX - transferência da família real para a colônia e crise de abastecimento agrícola para o mercado interno -, observam que 1808 se configuraria como marco

3 MARCIS, Teresinha. Op., cit., p. 205.

4 Idem, p. 218.

5 Idem, ibidem

6 Idem, ibidem. 
para a solidificação da produção de abastecimento interno, tendo o Rio de Janeiro como polo consumidor. Nessa direção, o deslocamento de mão de obra das zonas econômicas em crise, como a da mineração, para áreas de expansão agrícola colocaria em evidência a política de expansão territorial com base na apropriação de terras não colonizadas e utilizáveis.

Na região sul da Bahia, os deslocamentos econômicos para as novas áreas de interesse de expansão territorial, bem como abertura de estradas incidiram em maiores conflitos com as populações indígenas, habitantes daqueles territórios que, historicamente, resistiam ao processo colonizador, sobretudo os genericamente denominados botocudos. Esse termo traz em si o sentido pejorativo, que traduz a visão de animalidade e ferocidade que os colonizadores estabeleceram para tratar as populações resistentes ao processo da expansão territorial, durante o século XIX. Como observa Izabel Missagia de Mattos, o nome genérico, contudo, "abriga diversos subgrupos inter-relacionáveis"7. Apesar disso, a documentação produzida durante o século XIX poucas vezes nos permite enxergar os distintos grupos étnicos, pois a ideia era mesmo a de torná-los uma única massa, a dos "selvagens botocudos".

Nesse contexto, nas falas das autoridades provinciais e religiosas, os botocudos, habitantes das áreas ainda não ocupadas pelo Império, e resistentes ao processo de expansão territorial e construção de estradas, eram forjados como exemplo do malogro do projeto de ocupação e colonização e tidos como o maior obstáculo para o projeto econômico da família de Gonçalves da Costa, situação descrita por Paraíso como estopim para deflagração da Guerra Justa na região.

7 MATTOS, Izabel Missagia de. Civilização e revolta: os Botocudos e a catequese na Província de Minas. Bauru, SP: EDUSC, 2004, p. 30. 
A família Gonçalves da Costa foi beneficiada por concessão de sesmaria na região da Vila Imperial da Vitória (Vitória da Conquista), e levava à frente, naquela localidade, o projeto de implantação da pecuária. O desenvolvimento da pecuária e a formação de corredores de comércio com a abertura de estradas, a exemplo da estrada Ilhéus-Conquista, se configuraram nos principais motivos dos conflitos com os índios, segundo Paraíso ${ }^{8}$.

Portanto, em 1808 são decretadas, pelo Príncipe Regente, Cartas Régias declarando Guerra Justa aos “botocudos", visando "desinfetar os sertões" isso significava, nas palavras de Freitas e Paraíso, "garantir a mão de obra escrava aos novos conquistadores, abrir novas estradas e viabilizar a colonização de novos espaços"..$^{10}$

Com relação à Capitania de Ilhéus, segundo Freitas e Paraíso, o governo delegou aos capitães-mores da região a aplicabilidade das medidas determinadas pela Carta Régia de 1808, que declarava Guerra Justa aos "botocudos". Nesse contexto, a figura de Gonçalves da Costa seria fundamental, tendo em vista que o Capitão-mor teria prestado "relevantes serviços (...) na Conquista da Ressaca, onde organizara entradas nos vastos sertões de Gavião, Tamboril, Sucessos e rio de Contas. Segundo o Conde de Linhares, o seu trabalho se constituíra em liberar esses terrenos das incursões dos Botocudos e Pataxós

8 PARAÍSO, Maria Hilda Baqueiro. “Os Botocudos e sua trajetória histórica". In: CUNHA, Manuela Carneiro da (Org.). História dos índios no Brasil. São Paulo: FAPESP, Companhia das Letras, 1992, pp.416-417.

9 FREITAS, Antônio Guerreiro de; PARAÍSO, Maria Hilda Baqueiro. Caminhos ao encontro do mundo: a capitania, os frutos de ouro e a princesa do sul- Ilhéus, 1534-1940. Ilhéus: Editus, 2001, p. 51.

10 Idem, Ibidem. 
e aldear outras tribos mansas"11. De acordo com Paraíso ${ }^{12}$, era premente o interesse de Gonçalves da Costa e sua família em colonizar a região e facilitar o acesso e o escoamento de seus produtos e tropas para outras regiões.

Um dos focos principais para garantir o sucesso do projeto de colonização da região da Capitania de Ilhéus era a estrada que acompanhava o curso do Rio Pardo, e que ligaria Ilhéus, Conquista e Minas Gerais. "Em 1810", escrevem Freitas e Paraíso, "o engenheiro Felisberto Caldeira Brant foi nomeado para realizar estudos acerca da viabilidade do projeto"13; e optou por começar a abertura da estrada pelo curso dos rios Salgado e Cachoeira. No entanto, o projeto de abertura da estrada esbarrou nas dificuldades impostas pela presença massiva de indígenas não aldeados e resistentes ao projeto colonizador.

Em início do século XIX, por designação governamental, o ouvidor Balthazar da Silva Lisboa avaliaria as dificuldades relacionadas à construção da estrada entre Ilhéus e Minas, e concluiu que os grande problemas eram a ausência de colonos na região e a grande quantidade de índios não aldeados, que dificultavam o trânsito de viajantes e inviabilizavam o uso da estrada ${ }^{14}$. Havia crescente interesse governamental pelas terras ainda não colonizadas e cultivadas, pela construção da estrada como empreendimento que viabilizasse o trânsito de pessoas e mercadorias, bem como pela entrada de

11 Ofício enviado ao Conde da Ponte, Governador da Capitania da Bahia, Rio de Janeiro; 19/8/ 1809, Seção Decretos e Cartas Régias, Maço 1809, apud, FREITAS, Antônio Guerreiro de; PARAÍSO, Maria Hilda Baqueiro. Op., cit., 51-52.

12 PARAÍSO, Maria Hilda Baqueiro. Op., cit., 1992, p. 413-430.

13 FREITAS, Antônio guerreiro de; PARAÍSO, Maria Hilda Baqueiro. Op. cit., p. 52.

14 Idem, p. 53. 
colonos na região, que intensifica no sul da Bahia, no início do século XIX, a política de implantação de aldeamentos de catequese dos indígenas.

Conforme os quadros das aldeias da Província da Bahia do século XIX (Anexos 1 e 2), a política de aldeamentos de catequese seguiu na pauta governativa da Província da Bahia de forma crescente até a segunda metade daquele século, com foco nas questões sobre a colonização das terras e o aproveitamento do trabalho dos índios. Para a bibliografia especializada, a exemplo de Manuela Carneiro da Cunha, os interesses em torno da legislação indigenista e a problemática territorial sofreram mudanças ao longo do século XIX.

Note-se, contudo, que a política imperial valorizava o trabalho e a mão de obra indígena no processo da colonização, embora a apropriação territorial e a segurança dos colonos despertassem maior interesse e atenção da política indigenista daquele momento. Nas correspondências oficiais do período, trocadas entre autoridades locais e provinciais, o assunto trabalho indígena é uma preocupação constante e testemunha a continuidade efetiva da prática de uso intensivo desta mão de obra nas áreas de atuação dos aldeamentos. A exemplo de São Pedro de Alcântara (ver Anexo 3, Tabela 5), persiste, na segunda metade do século XIX, um evidente interesse pela mão de obra indígena, que recaía no cultivo da ascendente lavoura do cacau, principalmente.

As questões trabalho e apropriação territorial serão mais bem analisadas no terceiro capítulo. Por enquanto, podemos observar, nos quadros apresentados, o movimento de instalação de aldeamentos de catequese ao longo do século XIX. Observe que o total de aldeamentos existentes na Província da Bahia é apontado de forma imprecisa nos quadros dos Anexos (1 e 2). O Quadro de 1855 traz o 
total de 31 aldeamentos, e o de 1861, 36 aldeamentos. No entanto, é sabido que existiam outros estabelecimentos de índios aldeados naquele período, cujos nomes não constam nos mapas, à exemplo do de Verrugas ${ }^{15}$, localizado próximo a Conquista.

Outro ponto a ser frisado nessa etapa do texto é acerca das informações trazidas nos quadros sobre a situação jurídica das terras de cada aldeamento, condição apresentada de forma obscura porque não demonstra a situação territorial para todos os aldeamentos, e as que são citadas, o são de forma incompleta. As informações não nos permitem identificar minimamente se as terras de todos eles eram demarcadas, sua extensão ou a que administração estavam submetidas (se às Câmaras ou particulares, por exemplo). Sobre os aldeamentos de Ilhéus, por exemplo, o Quadro 1 (Anexo 1) não traz informação sobre a extensão territorial de nenhum deles; apenas acerca de dois deles existe a informação da demarcação ou não demarcação de suas terras. Nessa etapa, além do aspecto jurídico, atentaremos para a questão do cultivo das terras dos aldeamentos. A meta agora é a de explicitar, conforme as fontes permitam, como se dava o movimento de territorialização das populações indígenas na Bahia oitocentista, um dos nossos objetivos.

João Pacheco de Oliveira utiliza a noção de território para pensar sociedades cuja formação tem o território como o fator que regula as suas ações. Ele sugere que a incorporação de uma sociedade à situação colonial é um dos elementos mais significativos de sua transformação

15 CAMPOS, João da Silva. Crônicas da Capitania de São Jorge dos Ilhéus. Rio de Janeiro: MEC-CFC, 2006, p. 369. 
de sociedade segmentar em sociedade centralizada. ${ }^{16}$ Nesse sentido, a presença colonial "instaura uma nova relação da sociedade com o território, deflagrando transformações em múltiplos níveis de sua existência sociocultural". ${ }^{17}$ Oliveira propõe a noção de territorialização enquanto um ato político, no qual o conjunto de indivíduos ou grupos é enquadrado em determinado espaço geográfico. Esse ato político constitui objetos étnicos através dos mecanismos políticos arbitrários e exteriores ao grupo e às relações estabelecidas "entre os diferentes grupos que integram o Estado".$^{18} \mathrm{Na}$ perspectiva de Pacheco de Oliveira, a noção de territorialização deve ser tratada como um processo de via dupla, no qual os índios se apropriam do território delimitado pela agência colonial e participam diretamente de sua construção a partir das suas próprias motivações e interesses. $\mathrm{O}$ conceito de territorialização norteia nosso estudo no sentido de permitir pensar a instauração do aldeamento de Ferradas em dois níveis de análise: como mecanismo de intervenção dos governos colonial e imperial sobre os Camacãs, Pataxós e Gueréns daquela parte do sul da Bahia e, pensar como os aldeados, nas relações estabelecidas com os diversos agentes da colonização, no processo de territorialização, foram capazes de reconfigurar suas vidas na realidade colonial.

$\mathrm{Na}$ província da Bahia registrou-se no quadro de 1855, a atuação de 31 aldeamentos de catequese e no Quadro de 1861, um total de 36 aldeamentos, como já mencionado anteriormente. Não se trata de números exatos, pois

16 OLIVEIRA, João Pacheco de. "Uma etnologia dos índios misturados?" Situação colonial, territorialização e fluxos culturais. Mana. Rio de Janeiro: PPGAS Museu Nacional UFRJ, vol. 4, n. 1, 1998, p. 54.

17 Idem, Ibidem.

18 Idem, p. 56. 
os próprios registros existentes na documentação do período discorrem sobre as dificuldades de acesso a tais informações. No entanto, os quadros (ver anexos 1 e 2) nos permitem perceber, dentre outras questões importantes, onde estavam localizados os aldeamentos nas comarcas e nos municípios, bem como os fluxos das pessoas aldeadas.

Da mesma forma, ainda que não disponhamos de outros quadros demonstrativos referentes às décadas anteriores, podemos inferir que as informações disponíveis sobre a década de 1850 e início da década de 1860 delineiam um processo de continuidade da política de aldeamento e colonização regional iniciada antes, a exemplo dos aldeamentos coloniais de Abrantes, Santarém, Barcellos e São Fidelis. Ao longo do século XIX foram instituídos outros, a exemplo do objeto de estudo em questão, o aldeamento São Pedro de Alcântara. O estudo de Marcis traz as informações que nos permitem perceber a atuação inicial da política indigenista colonial na região.

$\mathrm{Na}$ Bahia, os aldeamentos jesuíticos passaram a atuar a partir de 1558 . Os primeiros aldeamentos foram estabelecidos em Salvador e no Recôncavo. Os aldeamentos de catequese só começaram a acontecer na Capitania de Ilhéus "após a guerra empreendida contra os tupiniquins, ordenada e conduzida pessoalmente por Men de Sá"19, em 1559. A partir de então, outros tupiniquins formaram aldeamentos como os de São Miguel, em 1561, e os de Nossa Senhora de Assunção, ambos em Camamu. Teresinha Marcis salienta que as populações aldeadas eram constantemente acometidas por epidemias, que tinham como principal motivo o modelo de aldeia adotado pela companhia jesuítica, de aglomerar uma vasta quantidade

19 MARCIS, Teresinha. Op., cit., p. 189. 
de índios num mesmo aldeamento. Salienta, ainda, que os aldeamentos jesuíticos foram constantemente reconstruídos e remanejados ${ }^{20}$.

Sobre outros aldeamentos coloniais, Marcis observa que, na ocasião da vinda do ouvidor Freire de Veras para a Capitania de Ilhéus, em 1759, a fim de realizar trabalhos de reforma nos aldeamentos, que compreendiam a instalação das vilas ${ }^{21}$, constatou não se ter uma definição clara para a data de criação do aldeamento de Nossa Senhora da Escada dos Ilhéus, vila de Olivença. No entanto, o primeiro registro de batismo data de $1682^{22}$. Já o aldeamento de Nossa Senhora das Candeias de Maraú, vila nova de Barcelos, tinha sua fundação correspondente a 1690, visto que seu primeiro registro de batismo data desse período, aproximadamente. Segundo Marcis, os indígenas de ambos os aldeamentos eram tupis, como descrevia o ouvidor Freire de Veras; outro aldeamento visitado pelo ouvidor foi o de Santo André e São Miguel do Serinhém, Vila Nova de Santarém. Embora o primeiro sacramento registrado tenha ocorrido em 1672, existe a possibilidade de sua existência inicial ter ocorrido em décadas anteriores ${ }^{23}$.

Teresinha Marcis observa, em seu estudo, que os aldeamentos instalados pelos padres jesuítas na Capitania de Ilhéus tiveram um tempo longo de atuação, porque mantinham a característica de agregar novos aldeados permanentemente, o que lhes garantia manter a estabilidade dos aldeamentos ${ }^{24}$. Dessa forma, em meados do século XIX coexistiam antigos aldeamentos coloniais

20 MARCIS, Teresinha. Op., cit., p. 191

21 Idem, p. 196.

22 Idem, p. 197.

23 Idem, p. 199.

24 MARCIS, Teresinha. Op., cit., p. 215. 
juntamente com aqueles instalados no período imperial, conforme demonstra o quadro dos aldeamentos da província da Bahia, de 1861.

Embora haja obscuridades nos quadros demonstrativos dos aldeamentos da Província da Bahia, nos quais muitas informações são omitidas, e em outros aldeamentos quase nenhuma informação se obtenha, cruzando os dois quadros podem ser percebidos aspectos importantes sobre a dinâmica da colonização e do trabalho indígena na Bahia oitocentista. A obscuridade do documento diz respeito, sobretudo, à situação das terras dos aldeamentos. O quadro 2 (anexo 2), por exemplo, cita que haviam terras cultivadas com vários gêneros e que haviam terras não cultivadas por índios. No entanto, omite a situação de cultivo das terras de diversos aldeamentos, e com referência aos de Ilhéus, não dispõe de dados sobre nenhum deles. Além disso, no quesito ocupação dos índios, nada consta a respeito. No quadro 1 (anexo 1) poderíamos observar a extensão territorial dos aldeamentos da Bahia e a situação jurídica de suas terras dos mesmos, caso as informações fossem apresentadas para todos os aldeamentos. Contudo, apenas para alguns aldeamentos são apresentadas as referidas informações de forma satisfatória. Com relação à maior parte deles, as informações são incompletas.

Com referência aos aldeamentos de Ilhéus, as informações são ainda mais imprecisas, pois apenas sobre os aldeamentos de Catolés e Barra do Salgado existe a informação de que suas terras não são demarcadas; sobre os demais, existe somente a informação de que se ignora a extensão. Prevalecia, portanto, certa negligência com relação à transmissão de informações dos missionários e autoridades de Ilhéus, acerca dos aldeamentos, para a capital da província. Telma Moreira de Souza observa que o Visconde de Sergimirim, quando assumiu o cargo de Diretor 
Geral dos Índios, reclamou ao presidente da província as dificuldades para elaboração do seu relatório, porque os diretores não enviavam informações das aldeias que administravam ${ }^{25}$.

No anexo 1 é apresentado o quadro das aldeias da Província da Bahia de 1855, onde se pode observar a preocupação provincial acerca das seguintes informações: o nome da comarca, o nome do aldeamento, número de índios dos aldeamentos, estado de "civilização" dos mesmos, nome do missionário que os dirigia, vencimento recebido pelos missionários, a extensão territorial do aldeamento, bem como um campo para as observações acerca de cada aldeamento. Note-se, além disso, que todas as observações são referentes à situação das terras dos aldeamentos. Na coluna observações, a situação das terras dos aldeamentos é apresentada de forma heterogênea, tanto em relação à extensão ocupada quanto em relação à situação administrativa das terras. Em muitos aldeamentos a extensão territorial é ignorada ou não registrada, e em outros as terras aparecem como sendo exploradas pelas Câmaras e arrendadas. Há ainda o registro de aldeamento em terras particulares. Tal heterogeneidade reflete a complexa teia estabelecida para a conquista e territorialização dos indígenas, desde finais do século XVIII, e que vai se delinear de forma mais coesa a partir das legislações editadas em meados do XIX, a saber, o engendramento dos interesses de aldeamento de catequese e a civilização dos índios para

25 SOUZA, Telma Moreira de. Entre a cruz e o trabalho: a exploração da mão de obra indígena no sul da Bahia (1845-1875). Dissertação de Mestrado. UFBA, 2007, p. 130. 
fins da colonização e expansão territorial do Império do Brasil $^{26}$.

Ao estabelecer uma aproximação das informações sobre a situação territorial dos aldeamentos da província do quadro 1, de 1855 (ver anexo 1), com as informações do quadro 2 de 1861 (ver anexo 2), mais especificamente o quesito pretensão de terras, pode-se obter dados importantes sobre a exploração agrícola dos aldeamentos. Esse quesito apresenta informações sobre terras cultivadas e com gênero de cultura e terras não cultivadas pelos índios, e a partir disso podemos inferir acerca da atuação indígena na atividade da agricultura, bem como sobre a possibilidade do cultivo agrícola em território de aldeamento por não índios. Como existia um percentual de terras não cultivadas por índios, isso leva a crer que nas terras do aldeamento coabitavam índios e não índios, uma estratégia da política indigenista para fins da "assimilação". No entanto, essa estratégia da mistura aparentemente não ocorreu em São Pedro de Alcântara, pois não encontramos informações que nos permitem afirmar que ali ingressaram não índios para cultivar terras. Apesar disso, explicitaremos, ao longo do trabalho, com base em outros registros documentais, que a relação entre índios e não índios foi muito estreita em Cachoeira de Itabuna, embora os não índios não vivessem dentro do perímetro do aldeamento.

26 Ocupados em discutir os meandros e engendramentos da política indigenista imperial, podemos destacar: CUNHA, Manuela Carneiro da. "Política indigenista no século XIX". In: CUNHA, Manuela Carneiro da (Org.). História dos índios no Brasil. São Paulo: FAPESP, Companhia das Letras, 1992; MOREIRA NETO, Carlos de Araújo. Os índios e a ordem imperial. Brasília: CGDOC-FUNAI, 2005; SAMPAIO, Patrícia Melo. "Política indigenista no Brasil imperial". In: GRINBERG, Keila; SALLES, Ricardo (Orgs.). O Brasil Imperial, volume I: 1808-1831. Rio de Janeiro: Civilização Brasileira, 2009; SAMPAIO, Patrícia Melo. Espelhos partidos: etnia, legislação e desigualdade na Colônia. Manaus: Editora da Universidade Federal do Amazonas, 2011. 
No quadro1 (anexo 1), a situação territorial dos aldeamentos não está bem definida, visto que não traz informação sobre a extensão territorial de alguns deles. Sobre a situação jurídica de suas terras, podemos identificar informações precisas sobre alguns deles, como já explicitamos acima. No Quadro 2 (Anexo 2), contudo, podemos suscitar duas questões, a nosso ver pertinentes para se pensar os problemas de catequese, civilização, colonização e ocupação territorial. A primeira refere-se à demonstração acerca das terras indígenas cultivadas por diversos e as não cultivadas por índios. Embora não se apresente dados de forma clara para todos os aldeamentos, é importante questionar o que significava dizer terras cultivadas com diversos. Os índios aldeados participavam ativamente da economia regional, atuando em uma agricultura comercial e diversificada? A segunda questão diz respeito às terras não cultivadas pelos índios, pois isso sugere que os aldeamentos podiam ser um espaço complexo no que toca às relações estabelecidas entre diferentes sujeitos étnicos e sociais.

As questões levantadas não permitem respostas rápidas e imediatas, pois as informações apresentadas nos quadros aqui analisados são insuficientes para isso. $O$ objetivo é apenas suscitar essas questões, que serão retomadas e discutidas com o apoio de outras fontes ao longo do trabalho. O que já podemos inferir é que os homens e as mulheres em "situação de aldeamento" foram sujeitos ativos no processo histórico e participavam da economia regional, pois, como bem frisa Marcelo Henrique Dias em seu estudo $A$ inserção econômica dos aldeamentos jesuíticos 
na capitania de Ilhéus ${ }^{27}$, esta população participava de forma efetiva na produção e circulação de mercadorias, num processo que envolvia toda a capitania. Tal assertiva de Dias refere-se ao mundo colonial, e não pode ser transportada para a atuação dos indígenas aldeados do século XIX de forma automática. Contudo, permite afirmar que a atuação dos índios na dinâmica da produção agrícola para fins de abastecimento e comércio não era uma situação estranha para as populações aldeadas da região.

Na fala do Presidente da Província João Maurício Wanderley, na abertura da Assembleia Legislativa da Bahia, de 1853, registra-se a seguinte informação:

[...] S. Pedro d'Alcantara, situado à margem septentrional do Rio Cachoeira, 12 legoas acima da Villa de Ilhéos [...]. Esta aldêa tem hoje por missionario e director Fr. Vicente de Ascoles dotado de muita energia que tem chamado os índios ao trabalho com perseverança, fazendo-os plantar mais de vinte mil pés de café e vinte mil de cacao, e produzir farinha, arroz e feijão bastante para alimentação das 38 famílias da tribu Camacan, que ali há com 196 indivíduos. ${ }^{28}$

O fragmento citado demonstra que, a exemplo do que acontecia no tempo dos jesuítas, estudado por Dias, os índios dos aldeamentos da Bahia oitocentista, em particular do sul da Bahia, eram sujeitos ativos e

27 DIAS, Marcelo Henrique. “A inserção econômica dos aldeamentos jesuíticos na capitania de Ilhéus". In: Um lugar na história: a capitania e comarca de Ilhéus antes do cacau. CARRARA, Ângelo Alves; DIAS, Marcelo Henrique (Orgs.). Ilhéus: Editus, 2007b, p. 230.

28 Fala que recitou o presidente da Província da Bahia, João Maurício Wanderley, $1^{\circ}$ de março de 1853, p. 35. In: Relatórios Provinciais Presidenciais (18301930). Disponível em: <http: / / www.crl.edu/brazil/provincial/bahia>. 
sua mão de obra importante na economia do café e do cacau, funcionando como parte integrante do motor de desenvolvimento econômico da região. Difícil pensar que os índios plantavam para a subsistência apenas, quando a documentação menciona uma produção agrícola vasta e de proporções consideráveis. Além do mais, deve-se levar em consideração a característica histórica da capitania de Ilhéus, fornecedora de produtos para o comércio entre a capitania, a capital e o Recôncavo ${ }^{29}$, e a proeminência da atuação indígena nesse processo.

\subsection{Ocupação e exploração territorial: a instalação do aldeamento São Pedro de Alcântara, em Ferradas}

Antes de discutirmos a fundação do aldeamento São Pedro de Alcântara, se faz necessário pontuar a existência de dois núcleos distintos de povoamento naquela região: o núcleo de Ferradas, de população indígena aldeada, e o de Cachoeira de Itabuna, que em meados do século XIX era composto por migrantes, sobretudo sergipanos. Percebemos, nesse encontro entre índios e não índios, diversas facetas da situação de fronteira, na qual se encontravam os aldeados de Ferradas, fazendeiros, botocudos requerentes de aldeamento, botocudos, noc-noc que impunham resistência aos empreendimentos da colonização, o missionário e autoridades governamentais ${ }^{30}$.

29 DIAS, Marcelo Henrique. Op., cit., 2007b, p. 114-115.

30 No escopo do aparato teórico que trata do conceito de fronteira, destacamos neste estudo: João Pacheco de Oliveira (1998), Maria Regina Celestino de Almeida (2001; 2013) e Vânia Losada Moreira (2010; 2011), que trataram da questão da construção de fronteiras étnicas no mundo territorializado. Nesse bojo de reflexão teórica sobre fronteira, são fundamentais os direcionamentos teóricos de Frederik Barth, 2011: Grupos étnicos e suas fronteiras, como referência fundamental para pensar a ideia de fronteira étnica entre os grupos sociais em situação de contato. 
E por fronteira deve-se entender, tal como explica Laura Muñoz, um espaço de encontro entre o mundo dos índios e o mundo dos colonizadores. A autora, que trata o processo de colonização do Caribe e as diversas fronteiras estabelecidas, define fronteira como o "espaço onde [os] dois mundos se tocavam pela colonização [...], pelo intercâmbio [...], seu caráter de fronteira excedeu o de uma linha divisória e se converteu, melhor, em uma área ampla, variável e complexa, de contatos, cruzes e mesclas". ${ }^{31}$ Tais fronteiras eram, além disso, fluidas, intercambiáveis.

$\mathrm{Na}$ introdução de Espacios de interacción en las tierras bajas del sur de América, Nacuzzi pontua a proposta de apresentar os espaços de fronteira colonial sul-americano em seus termos geográficos, sem, contudo, desmerecer a importância de se perceber a fronteira como espaço de contato entre os sujeitos. Para Nacuzzi, se hoje temos os estudos sobre fronteira desenhados como espaço de atuação dos grupos e sujeitos, não se deve perder de vista que tais espaços de fronteira foram estabelecidos inicialmente pelo colonizador: "lós que eligieron o determinaron los lugares donde estabelecieron fuertes, misiones o ciudades [...], eligieron los lugares del contacto, o por lo menos, tomaron las primeras iniciativas para que algunas fronteras se crearan donde se crearon" ${ }^{32}$. Ou seja, na perspectiva da autora, é importante não abandonar a noção de limite delineada no processo de colonização, porque essa noção permitiu que se delineasse também

31 MUÑOZ, Laura. "Bajo el cielo ardiente de los trópicos: Las fronteras del Caribe em el siglo XIX”. In: Fronteiras: Paisagens, personagens, identidades. GUTIÉRREZ, Horácio; NAXARA, Márcia R. C. e LOPES, Maria Aparecida de S. (Orgs.). Franca: ENESP, São Paulo: Olho d'Água, 2003, p. 55.

32 NACUZZI, Lidia R. "Introdução". In: LUCAIOLI, Carina; NACUZZI, Lidia. (Orgs.). Espacios de interacción en las tierras bajas del sur de América. Buenos Aires: Sociedad Argentina de Antropologia, 2010, p. 12. 
a zona de contato dos espaços de sociabilidade e de trânsito. Em outras palavras, a partir da noção de fronteira geográfica, que separa, limita e, ao mesmo tempo, se constitui do contato e ação de pessoas, grupos, e povos, foi possível construir a noção de fronteira enquanto espaço da interação destas pessoas, povos, e suas culturas. A fronteira, portanto, é entendida como "espaço transicional" permeado de conflitos, interações, estratégias, negociações, ressignificações.

A ideia de Nacuzzi condensa, em certa medida, os contornos dos capítulos II e III do nosso trabalho, onde demonstraremos que a ideia de limite da fronteira, delineada pelos propósitos da colonização, visa demarcar territórios, avançar e conquistar sertões. Nos referidos capítulos, nossa preocupação central é situar o processo de territorialização de populações indígenas no sul da Bahia, criação dos diferentes espaços da atuação colonizadora - Ferradas e Cachoeira de Itabuna - naquela parte da região, e as relações estabelecidas entre os atores sociais.

Também pretendemos, ao longo deste estudo, demonstrar que a paisagem do delineamento geográfico da conquista, ou seja, o de ocupação dos espaços fronteiriços e exploráveis foi, aos poucos, modificada pelas relações cotidianas estabelecidas entre os diferentes atores envolvidos no projeto colonizador. A fronteira perdeu seu caráter geográfico inicial e se converteu em espaço de intercâmbios, trânsitos e fluidez.

Em 1814, foi fundado o núcleo indígena São Pedro de Alcântara, que ficaria conhecido também como aldeamento de Ferradas e atuaria de forma decisiva na ocupação territorial da região, atendendo a uma política de colonização nos termos dos interesses do período colonial e, subsequentemente, imperial. Vale ressaltar que, nos moldes de São Pedro de Alcântara, muitos outros aldeamentos foram 
instalados no sul da Bahia ao longo do século XIX, com o intuito de tornar transitável e explorável o território que compreendia, principalmente, a região dos rios Cachoeira ou Colônia e Pardo. Note-se, além disso, que os aldeamentos instalados naquela região formavam um corredor entre Ilhéus e Conquista (vide mapa abaixo).

FIGURA 1 - Aldeamentos do sul da Bahia

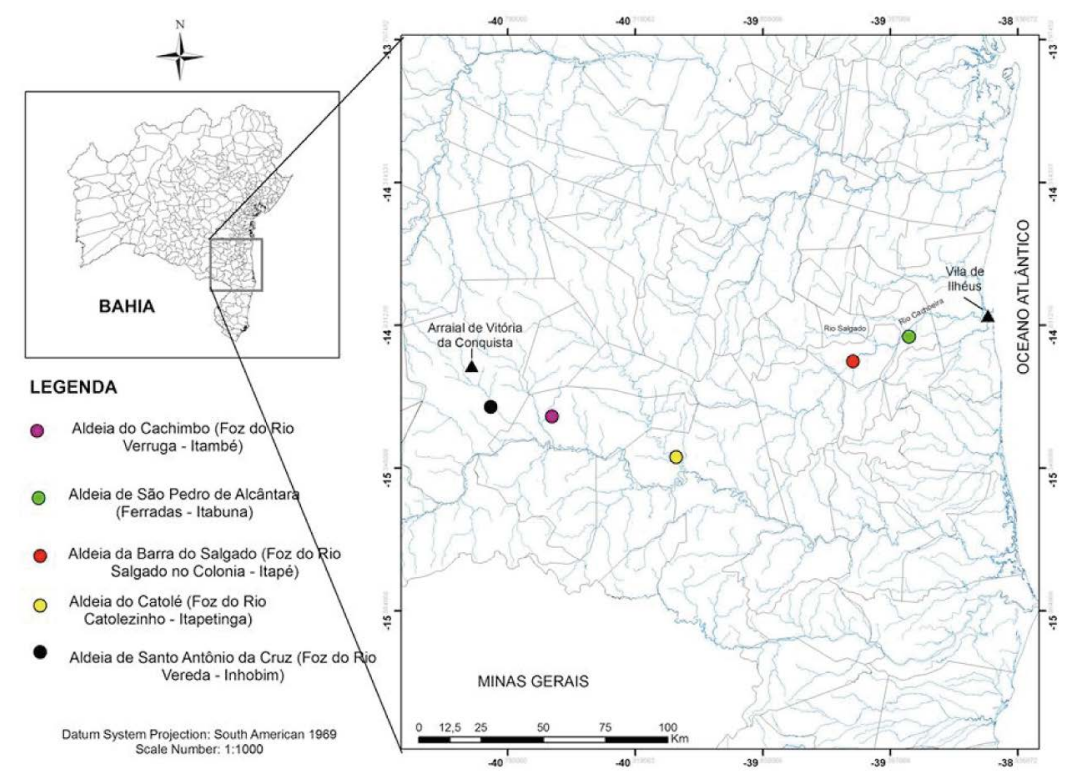

Fonte: Mapa confeccionado por Girleney Araújo, para a presente pesquisa.

Nessa perspectiva de fundação de núcleos de povoamento por meio da criação de aldeamentos de catequese, se consolidará, na região do rio Cachoeira, o núcleo de migrantes denominado de Cachoeira de Itabuna, que hoje corresponde à atual cidade de Itabuna. As informações sobre esse núcleo de povoamento são escassas. A documentação que trata do aldeamento e as escrituras dos livros de notas da vila de Ilhéus fazem menções corriqueiras ao núcleo Cachoeira de Itabuna, visto que, na primeira déca- 
da do século XIX, já se comprava e vendia terras no núcleo denominado de Cachoeira de Itabuna e, nos registros paroquiais da década de 1850, são registradas as terras da Cachoeira de Itabuna, mas não nos oferecem maiores informações. Sendo assim, nos restam as observações de João da Silva Campos, trabalho cuja primeira edição corresponde a $1947^{33}$. Ainda que o autor nem sempre identifique as fontes apresentadas, sua obra se configura como uma importante contribuição para a história de Ilhéus e se constitui numa referência de citação quase obrigatória para os estudos regionais, sobretudo pela importante compilação de documentos sobre o sul da Bahia, que abrange um amplo marco temporal.

João da Silva Campos observa que, em 1818, o estrangeiro Pedro Weyll e outro companheiro haviam adquirido terrenos à margem esquerda do rio Cachoeira, iniciando, assim, a colonização estrangeira em Ilhéus. Segundo Campos, naquela localidade, os alemães teriam formado a colônia de São Jorge da Cachoeira de Itabuna, composta de "28 casais com 161 indivíduos," que teriam chegado à região alguns anos depois do estabelecimento de Pedro Weyll naquela localidade. Contudo, diante das dificuldades em manter a colônia em funcionamento, ela não vingou. Uma segunda leva de imigrante foi destinada à colônia, no ano de 1823, e teve o socorro dos cofres da Assembleia Geral, com uma verba de $4.384 \$ 300$ réis. $^{34}$

33 Muito embora a data da primeira edição do livro Crônica da Capitania de São Jorge dos Ilhéus conste do ano de 1947, ele foi escrito na década de 1930 por encomenda do então intendente de Ilhéus Eusínio Lavigne, como nos lembra Marcelo Dias na introdução de sua tese de doutoramento: DIAS, Marcelo Henrique. Economia, sociedade e paisagens da Capitania e Comarca de Ilhéus no período colonial. Tese. UFF, Niterói-RJ: 2007a.

34 CAMPOS, João da Silva. Op., cit., p. 323-324. 
As informações trazidas por Silva Campos confirmam a existência do núcleo Cachoeira de Itabuna já nas primeiras décadas do século XIX. Ele cita o ano de 1818, contudo nossa documentação registra um processo de compra e venda de terras em Cachoeira de Itabuna já em 1814 (p.160). A disparidade das datas entre as informações colhidas na documentação levantada e a menção do núcleo por Campos se devem, provavelmente, a certa incongruência de datas e informações presentes em sua obra. De certo, Weyll e outros estrangeiros desempenharam papel importante na história da ocupação territorial e exploração do trabalho indígena na região, como veremos mais adiante. Por ora, importa observar que aquele núcleo de povoamento foi fundado nas primeiras décadas do século XIX e a existência de comercialização de terras em Cachoeira de Itabuna segue por toda a primeira metade do Oitocentos.

O mesmo Silva Campos, referindo-se novamente à Cachoeira de Itabuna, utiliza informações do Almanak de Itabuna, e menciona que, por volta de 1860 , teria começado a ser povoado aquele núcleo, onde seria erguida a cidade de Itabuna. Entendemos, contudo, que aquela colônia falida na década de 1820 pode ter tido suas terras ocupadas por aqueles que ali permaneceram com suas posses, e, talvez, enfrentado estágios de despovoamento, já que a colonização daquela região enfrentaria, por todo o século XIX, a presença resistente de populações indígenas. Dessa forma, faria sentido o registro do [re] povoamento de Cachoeira de Itabuna em meados do século XIX por migrantes nacionais. Campos enfatiza que:

[...] sendo os seus primeiros moradores quase todos sergipanos. Em princípio de 1861 já a câmara de Ilhéus pedia a criação de um distrito policial em Cachoeira de Itabuna, zona onde existia grande população, não 
somente de naturais do município, como do centro e do norte da província, e de Sergipe, que para ali afluíam desde alguns anos atrás, abrindo roças e fazendas ${ }^{35}$.

A data de criação do núcleo dada pelo autor é imprecisa, mas as escrituras dos livros de notas, bem como os Registros Paroquiais de Terras (1857-1862) da vila de Ilhéus e as correspondências testemunham a existência do núcleo num período anterior ao exposto por Silva Campos. Inferimos, a partir do acompanhamento das fontes, que o núcleo não deixou de existir após a falência da colônia estrangeira ou da tentativa de manutenção da mesma; os colonos que ali se estabeleceram permaneceram e aumentaram suas posses, visto que, algumas décadas mais tarde, Cachoeira de Itabuna, posteriormente denominada de Tabocas, se constituirá de pequenas fazendas de cacau, como observa Fernando de Staiger em correspondência acerca das obras na estrada Ilhéus-Conquista, em $1868 .^{36}$

Contudo, o trabalho de Silva Campos fornece pistas importantes sobre a fundação do povoado. Ele nos permite perceber os delineamentos da ocupação territorial daquela região com foco na relevância da atuação do aldeamento de Ferradas para o cumprimento do projeto colonizador. O próprio Silva Campos menciona que, por ocasião da chegada dos migrantes nortistas, eles "procuravam a parte mais cultivada do município de Ilhéus que era às margens do rio Cachoeira, localizando-se até a aldeia de Ferradas" ${ }^{37}$. A fala de Silva Campos pode ser corroborada

35 CAMPOS, João da Silva. Op., cit., p. 380.

36 APEB: Seção Arquivo Colonial e Provincial; série Justiça-correspondências juízes de Ilhéus; maço 2401; ano 1868, fl. 8.

37 CAMPOS, João da Silva. Op., cit., p. 391. 
com o testemunho do juiz de direito de Ilhéus, Antônio Villaça, que em 22 de julho de 1868 escreveu ao presidente da província, José Bonifácio Nascimento, esclarecendo que os migrantes destinados à colônia de Comandatuba deveriam devolver o valor empregado pelo governo com suas passagens, visto que, ao chegarem à região, "mudaram de resolução, e pretendem estabelecer-se em lavoura no Rio Cachoeira de Itabuna, onde encontraram alguns parentes, que vivem da lavoura". ${ }^{38}$

Os estudos regionais apontam para a importância dos aldeamentos no processo de ocupação territorial na região, a exemplo de Freitas e Paraíso, que afirmaram, em seu estudo, que no processo colonizador em Ilhéus, a preferência recaía sobre as áreas de aldeamentos ${ }^{39}$; também as observações acerca das escrituras de compra e venda de terras nos permitem perceber, ao longo do século, o crescente movimento de ocupação e exploração territorial, com a formação de plantações e fazendas de cacau. Podemos inferir, portanto, que aqueles núcleos, isto é, Cachoeira de Itabuna e Ferradas, embora fossem núcleos distintos, estavam totalmente correlacionados. Mostra disso é a fala do juiz de órfãos de Ilhéus:

[...] Havendo a tribu noc-noc pelos botocudos continuado suas incursões sobre as Ferradas e passando destas para baixo ameaçando já os fazendeiros de Cachoeira de Itabuna, julguei que devia aproveitar os apresentados [botocudos que requeriam aldear-se] e seu guia para unidos com alguns

38 APEB: Seção Colonial e Provincial; série Justiça-correspondências juízes de Ilhéus; maço 2401; ano 1868.

39 FREITAS Antônio Guerreiro de; PARAISO, Maria Hilda Baqueiro. Op., cit., p. 65. 
Camacans sob a direção do reverendo Missionário [...] entrarem nas mattas a ver se podiam conseguir o aldeaimento daquella tribu assim nocivo ${ }^{40}$.

O núcleo indígena e o núcleo de nacionais eram próximos o suficiente para que os ataques dos noc-noc a Ferradas logo tivessem alcançado Cachoeira de Itabuna. Dentre outros papéis, Ferradas desempenhava o de garantir a segurança dos fazendeiros de Cachoeira de Itabuna. Notase que a preocupação central do juiz e delegado Antônio D'Aguiar Silva é com a segurança dos fazendeiros, que os Camacãs de Ferradas, juntamente com botocudos apresentados ao frade Ludovico, tinham a tarefa de garantir.

A fundação do aldeamento São Pedro de Alcântara ou Ferradas deve ser analisado pela perspectiva da política indigenista da virada do século XVIII para o XIX, que visava atender à demanda colonial de conquista dos sertões, de colonização e garantia da mão de obra para os serviços públicos e particulares ${ }^{41}$. Nesse contexto, o significado empregado para a palavra "sertão" revela a positivação do sentido da conquista, visto que conquistar os sertões significava levar a "civilização" para as áreas ainda não ocupadas e exploradas pelo governo colonial e, subsequentemente, imperial. Nas palavras de Vânia Moreira, “[...] o sertão era, em primeiro lugar, o oposto do mundo policiado, pois não se assemelhava à 'civilização' e nem

40 APEB: Seção Arquivo Colonial e Provincial; série Justiça-correspondências juízes de Ilhéus; maço 2395-I; 1843.

41 Sobre as políticas indigenistas voltadas a atender o projeto de colonização e captação de mão de obra indígena, ver: MOREIRA NETO, Carlos de Araújo (2005); SAMPAIO, Patrícia melo (2009, 2011); CUNHA, Manuela Carneiro da. (1992); ALMEIDA, Maria Regina Celestino de. (2013); MOREIRA, Vânia Losada (2010). 
tampouco estava sob a jurisdição política da monarquia portuguesa e do "bom governo"42.

$\mathrm{Na}$ área da Comarca de Ilhéus, o projeto de conquista das regiões interioranas esbarrava na resistência, em certo grau, dos Camacãs, e em maior intensidade dos Pataxós e, sobretudo, dos botocudos, populações que eram, historicamente, as legítimas donas daqueles territórios. Segundo a bibliografia regional especializada, "os índios continuavam a ser apontados como o obstáculo mais difícil de ser superado na concretização dos empreendimentos de conquista, colonização e abertura de estradas" ${ }^{\prime 3}$, o que tentava justificar as medidas para "conquistar" ou "desinfetar" os sertões. O testemunho do capitão-mor Antônio Dias de Miranda, membro da família Gonçalves da Costa, cuja atuação provocou intensos conflitos com as populações indígenas da região, como já mencionamos, é elucidativo quanto às práticas contraditórias do governo local acerca das políticas adotadas para os Camacãs, Pataxós e botocudos, habitantes do sul da Bahia. Garantir a civilização significava conquistar os sertões, aldear os índios e até mesmo expulsá-los dos territórios a serem ocupados. Nas palavras de John Monteiro, "atrair ou repelir, civilizar ou exterminar [...]. A noção de civilização, ao que parece, abrigava os dois extremos." ${ }^{44}$

42 MOREIRA, Vânia Maria Losada. "Entre as vilas e os sertões: trânsitos indígenas e transculturações nas fronteiras do Espírito Santo (1798-1840)", Nuevo Mundo, Mundos Nuevos [Online], Debates, posto on-line no dia 31 janeiro 2011. Acesso em: 8 mar. 2014. Disponível em: <http:/ / nuevomundo. revues.org/60746>. DOI: 10.4000/nuevomundo. 60746, p. 1.

43 FREITAS, Antônio Guerreiro de; PARAÍSO, Maria Hilda Baqueiro. Op. Cit., p.50.

44 MONTEIRO, John Manuel. Tupis, Tapuias e historiadores: Estudos de História Indígena e do Indigenismo. Tese de livre docência. Unicamp: Campinas, 2001, p. 143. 
Antônio Dias de Miranda, em 26 de dezembro de 1826 , se reporta ao presidente da província lembrando que sua família historicamente atuava naquela região, na altura do Rio Pardo. Informava que as patentes militares recebidas pelos homens de sua família eram em merecimento pelo árduo trabalho de conquista dos sertões, prestado ao governo, bem como pelas despesas financeiras assumidas por eles para tal fim:

Antonio Dias de Miranda, capitão mor da conquista do certão da ressaca, reprezenta a V. Excia. que tendo sido a mesma conquista concluída acusta das fadigas, e dispezas de seu avo, e finado pai João Gonçalvez da Costa (...), aquelles habitantes da conquista costumados a empreheinderem grandes emprezas contra os índios, Mongoiós, Patachó, e Botocudos, q' os costumavão invadir, não podem levar a bem o serem chamados, para outro qualquer serviço, q' não seja, o de domarem, ou ao menos afugentarem os ditos índios, para civilisação, e augmento da sobredita conquista, no que muito se tem o suplicante empenhado, não se poupando por sy, e seus parentes, a todas as despezas, fadigas, e perigo de vida ${ }^{45}$.

$\mathrm{Na}$ fala de Antonio Dias de Miranda fica expresso que a estratégia de aldear os Camacãs, Pataxós e Botocudos da referida região não era a única existente. Quando se tornava difícil conseguir o aldeamento das populações, a estratégia adotada era bem diferente e recaía na expulsão dos mesmos de suas terras. Isso nos permite vislumbrar as tensões, os conflitos e as complexidades nas

45 APEB; seção Arquivo Colonial e Provincial; série Agricultura; maço 4613; ano 1826. 
relações entre colonizadores e indígenas no sul da Bahia oitocentista. Vale ressaltar, no entanto, que no conjunto da documentação analisada, a estratégia predominante durante o século XIX é a de estabelecimento de aldeamentos de catequese na região, em lugar da mera expulsão dos índios dos territórios sul baianos.

A história sobre a instalação do aldeamento São Pedro de Alcântara, em Ferradas, até bem pouco tempo atrás era bastante controversa. Freitas e Paraíso, em Caminhos ao encontro do mundo: a capitania, os frutos de ouro e a princesa do sul, frisam como figura central no processo de criação do aldeamento o Capitão-mor João Gonçalves da Costa. A monografia de Cordeiro ${ }^{46}$ versa acerca da atuação capuchinha na Comarca de Ilhéus e traz algumas informações sobre a chegada de Frei Ludovico de Livorno (Liorne) àquela localidade, mas revela pouco acerca do envolvimento do missionário no processo de fundação e desenvolvimento do aldeamento.

Segundo Freitas e Paraíso, ${ }^{47}$ os indígenas de São Pedro de Alcântara foram aldeados pela família de Gonçalves da Costa, e é importante frisar que, historicamente, essa família atuou no combate aos índios resistentes ao processo colonizador daquela região. Em Os Botocudos e sua trajetória histórica, Paraíso destaca que o estopim para a deflagração da guerra justa contra os "Botocudos", no sul da Bahia, teria ocorrido pela concessão de uma sesmaria à família do capitão-mor na região de Vitória da Conquista, então, vila Imperial da Vitória, quando os índios reagiram à construção de um corredor de comércio entre a região e

46 ANDRADE, João Cordeiro. Missões Capuchinhas na Comarca de São Jorge dos Ilhéus (1816-1875). Monografia. Ilhéus, UESC, 2003.

47 FREITAS, Antônio Guerreiro de; PARAÍSO, Maria Hilda Baqueiro. Op., cit., p. 53. 
Minas. A autora salienta, além disso, que a família de Gonçalves da Costa implantou a pecuária na região e, nesse sentido, era do seu interesse manter as vias de acesso aos comerciantes e às suas tropas ${ }^{48}$.

Contudo, mais recentemente, Teresinha Marcis, em sua tese de doutoramento, nos apresenta informações valiosas e mapeia a trajetória histórica que levaria à instalação do Aldeamento São Pedro de Alcântara, baseando sua pesquisa em informações colhidas no Arquivo Nacional da Torre do Tombo, bem como em fontes do Arquivo Histórico Ultramarino. Conforme a sólida reflexão de Marcis, a criação do aldeamento São Pedro de Alcântara está relacionado ao antigo aldeamento instalado às margens do rio Almada, que teria sido extinto, e os índios restantes transferidos para Ferradas. $\mathrm{Na}$ nova localidade, os índios foram aldeados juntamente com índios camacãs, que habitavam a referida região e que, com a abertura da estrada Ilhéus-Conquista, foram "descidos" para o aldeamento. Provavelmente, os Camacãs foram aldeados perto da estrada para garantir o sucesso do empreendimento, que poderia dispor, a partir de então, da mão de obra dos índios para sua conservação. Fundou-se, assim, em 1814, o aldeamento São Pedro de Alcântara ${ }^{49}$.

Teresinha Marcis recompõe, de forma muito interessante, a trajetória estabelecida entre o aldeamento de Nossa Senhora dos Índios Gréns do rio Almada e a instalação do novo empreendimento colonial em Ferradas, observando, no bojo desse processo, a atuação do então Ouvidor da Comarca, Balthazar da Silva Lisboa. A partir das informações colhidas pela pesquisa de Marcis, podemos traçar a teia de interesses relacionada à transferência dos

48 PARAÍSO, Maria Hilda Baqueiro. 1992, Op., cit., 1992, p. 416-417.

49 MARCIS, Teresinha. Op., cit., p. 241-246. 
aldeados do Almada para Ferradas. O pano de fundo é o suposto interesse do Ouvidor no beneficiamento de terras que supomos pertencerem a ele, pois foram compradas por Balthazar naquela região, algum tempo antes da instalação do novo aldeamento, conforme escritura de terra de $1814^{50}$. As informações de que dispomos não permitem afirmações conclusivas, mas tudo sugere uma sobreposição das terras compradas por Balthazar da Silva Lisboa e das terras destinadas ao aldeamento de Ferradas.

Na trajetória da extinção da Aldeia de Nossa Senhora dos Indios Gréns, localizada em Almada, e de instalação do aldeamento de Ferradas, a figura de Balthazar da Silva Lisboa é emblemática e central. Teresinha Marcis observa, na documentação compulsada, as contradições presentes nas medidas adotadas pelo ouvidor com relação ao aldeamento do Almada. Primeiramente, o pároco responsável pela freguesia, Francisco dos Santos Solledade, enviou requerimento, em 1796, ao Secretário de Estado dos Negócios Estrangeiros e de Guerra solicitando a extinção da aldeia devido à incapacidade de civilização dos Gréns, ali aldeados. Além disso, diante da cobrança da Mesa de Consciência e Ordem de esclarecimentos sobre o assunto, o Ouvidor da Comarca, Balthazar da Silva Lisboa, emitiu um parecer favorável à extinção do aldeamento.

No entanto, ressalta Marcis, quase imediatamente após o ocorrido, isto é, um mês depois, o ouvidor remeteu ao arcebispo da Bahia outro parecer, em que refutava todas as justificativas utilizadas pelo padre da freguesia para a extinção do aldeamento e defendeu a sua permanência. "O ouvidor concluía a defesa da manutenção da freguesia apelando para a história dos gréns, reforçando

50 APEB: Livros de Notas da Vila de Ilhéus; livro 5; ano 1814; folhas 39-40. 
a necessária proteção aos indígenas por honra da Igreja e do Estado." 51 Ainda ressalta a autora que o aldeamento e freguesia de Nossa Senhora dos Indios Gréns existiu no Almada até 1814, quando da sua extinção definitiva pelo mesmo ouvidor Lisboa, que outrora havia se colocado ferrenhamente contrário ao seu esfacelamento ${ }^{52}$.

Nesta ocasião, como já mencionamos anteriormente, estava em prática no sul da Bahia o projeto de abertura da estrada que seguia o curso dos rios Salgado e Cachoeira, tendo os índios habitantes daquela região, os camacãs, "aceitado" se estabelecer no aldeamento de Ferradas depois de um processo de resistência ${ }^{53}$. O interesse em aldeá-los recaía sobre a necessidade de mão de obra para trabalhar na estrada e possibilitar o trânsito na região. Sendo assim, os gréns do Almada teriam sido transferidos por Lisboa para o aldeamento São Pedro de Alcântara para dar suporte ao novo empreendimento colonial.

A documentação deixa bastante em evidência o papel decisivo do ouvidor Lisboa no esfacelamento do aldeamento do Almada e na instalação do novo aldeamento de Ferradas. Importa pensar sobre o interesse dessa autoridade colonial no engendramento de um processo, no mínimo, controverso. Desse modo, para construir a nossa argumentação sobre a teia de interesses, que pode servir como pano de fundo para entender as obscuras decisões do ouvidor concernentes à situação do aldeamento do Almada, vamos explorar a sugestiva e bastante elucidativa escritura de compra de terras no rio Cachoeira, efetuada pelo mesmo ouvidor Lisboa, em 1814.

51 MARCIS, Teresinha. Op., cit., p. 245.

52 Idem, p. 246.

53 Idem, ibidem 
Saibão quantos este publico Instrumento de escriptura de Venda de uma sorte de terras [...] no anno do Nascimento de Nosso Senhor Jesus Christo de mil oito centos e quatorze aos oito dias do mês de maio do dito anno nesta Villa de São Jorge Cabeça da Comarca dos Ilhéos caza de rezidencia do Doutor Desembargador Ouvidor desta Comarca Balthazar da Silva Lisboa [...] de uma parte como vendedor Francisco Soares da outra Balthazar da Silva Lisboa [...] dito vendedor [...] que elle pelo poder especial que tenha de sua procuração bastante passada pelo seu irmão, o Reverendo Ignacio Luiz Gonzaga de Essa vendia como de facto vendido tenha de hoje para todo o sempre huma sorte de terras ditas no Rio da Cachoeira de Itabuna [...] ao dito Senhor Doutor Balthazar da Silva Lisboa, pelo presso e quantia de quatrocentos mil réis, [...] cuja sorte de terra disse elle comprador as comprava para o Excelentíssimo Antonio de Araujo Azevedo morador da Corte do Rio de Janeiro $[\ldots]^{54}$.

A postura dúbia de Balthazar com relação à situação do aldeamento do Almada, ora a favor da extinção, ora defendendo de forma veemente a permanência do mesmo, e depois partindo do próprio ouvidor a decisão de extingui-lo, nos permite pensar que as decisões tomadas pelo ouvidor e a habilidade com que as colocou em prática estavam ligadas aos interesses comerciais de Lisboa naquela área de Ilhéus, na qual se encontrava instalado o projeto de abertura da estrada para viabilizar o desenvolvimento da região. Tendo como testemunho a referida escritura, nossa hipótese é a de que o ouvidor estava de fato movido

54 APEB: Livros de Notas da Vila de Ilhéus; livro 5, Ano 1814, folhas 39-40. 
pelo interesse de promover a efetiva colonização daquela região e, mais ainda, por promover o beneficiamento das terras de Ferradas em benefício próprio, já que as terras, ou parte delas, pertenciam a ele mesmo.

Todo esse processo, observamos, portanto, que se dá no mesmo mês da transferência dos índios Gréns para o então aldeamento São Pedro de Alcântara. As terras foram compradas, segundo Lisboa, para um amigo do Rio de Janeiro, de quem não se tem mais notícias na documentação. Sobre essa nebulosa transação comercial, Silva Campos, quando cita em seu trabalho o processo de fundação do aldeamento de Ferradas, frisa dizer-se "algures que as terras de Ferradas pertenciam ao desembargador" ${ }^{\prime \prime}$. Desse modo, tudo indica que o ouvidor era o verdadeiro proprietário e beneficiado daquela transação e usou como intermediário, ou "testa de ferro", um amigo da Corte para justificar a compra das referidas terras.

Nossa hipótese, portanto, é que Lisboa tinha fortes interesses na extinção do aldeamento dos índios Gréns em Almada e na imediata instalação de um novo aldeamento às margens do rio Cachoeira. Sua atuação aparentemente contraditória esteve relacionada ao objetivo de tornar as terras de Ferradas beneficiáveis pela presença de um aldeamento que garantisse o seu acesso e aproveitamento econômico. Afinal, a região era habitada por populações resistentes ao processo de colonização, que precisavam ser conquistadas, pacificadas e aldeadas, e o próprio aldeamento garantia mão de obra indígena para o seu desenvolvimento inicial.

Como já foi mencionado, a parte sul da comarca suscitava interesse comercial, visto que se configurava

55 CAMPOS, João da Silva. Op., cit., p. 305. 
como um incipiente corredor de comércio entre Ilhéus, Conquista e Minas. A abertura da estrada Ilhéus-Conquista visava ligar Ilhéus e Conquista a outras regiões, a exemplo de Minas, visto que tornaria possível o trânsito de pessoas, tropas e mercadorias. Note-se, além disso, que no início do século XIX essa região é descrita, pela historiografia regional, como inabitada por colonos. Era uma região de índios que, com o decorrer do século, terminou por atrair o interesse dos imigrantes e regionais. Como evidenciam Freitas e Paraíso, a preferência desses imigrantes recaía sempre sobre áreas de atuação dos aldeamentos ${ }^{56}$. Portanto, tendo Balthazar comprado as terras localizadas no rio Cachoeira, e tudo nos leva a crer que se tratassem das terras de Ferradas, era vantajoso para ele manter aquela área habitada por índios aldeados que, por sua vez, coadjuvariam principalmente como mão de obra.

Nossa tese de que o aldeamento de Ferradas foi um empreendimento colonial diretamente relacionado aos interesses econômicos do ouvidor Lisboa é reforçada por sua estreita e contínua relação com Frei Ludovico de Livorno, primeiro missionário a administrar, como religioso e diretor, o aldeamento São Pedro de Alcântara. Explicitaremos esse argumento nas análises que compreenderão os próximos parágrafos deste capítulo, tendo como base os Annaes do Rio de Janeiro, tomo VI, no qual Balthazar da Silva Lisboa publica algumas cartas que the são dirigidas pelo Frei Ludovico. Nelas podemos extrair relevantes informações que, em contrapartida, reforçam a nossa ideia sobre os interesses que permeavam a ação do ouvidor acerca daquela região.

56 FREITAS, Antônio Guerreiro de; PARAÍSO, Maria Hilda Baqueiro. Op., cit., p. 65. 
Convém ressaltar que a estreita relação estabelecida entre o ouvidor Lisboa e o frade Ludovico era consonante ao próprio papel que o cargo de ouvidor lhe imputava, pois os ouvidores exerciam um papel tutelar sobre o patrimônio dos índios. Manuela Carneiro da Cunha frisa que, sendo os índios considerados incapazes de administrar seus próprios bens, ficava o Estado responsável, portanto, por seus cuidados, sobretudo com relação às terras dos aldeamentos, "incumbindo a princípio os ouvidores das comarcas [até 1832] [...] da administração dos bens das aldeias." ${ }^{57}$ O papel central dos ouvidores na administração dos bens dos índios é confirmado pelo estudo de Vânia Moreira que, ao pesquisar acerca da administração das terras dos índios de Nova Benavente, na capitania do Espírito Santo, observou a teia estabelecida entre os diretores escrivães e os ouvidores nos eventos de usurpação das terras dos índios, quando eles reclamam "à rainha que os portugueses estavam tomando 'toda a terra dos índios', com o apoio do diretor escrivão e, pior ainda, com o consentimento dos ouvidores." ${ }^{58}$ Nessa perspectiva, inferimos que Lisboa, aproveitando-se das prerrogativas do cargo exercido na comarca de Ilhéus, à época, visava assegurar interesses econômicos pessoais a respeito das terras e mão de obra indígena no processo de instalação do aldeamento de Ferradas, como bem demonstra a documentação.

57 CUNHA, Manuela Carneiro da. Op., cit., p. 148.

58 MOREIRA, Vânia Maria Losada. “Nós índios, índios nós senhores de nossas ações... Direito de domínio dos índios e cristandade em conflito (vila de Nova Benavente, Capitania do Espírito Santo, 1795-1798)". In: Em terras lusas: conflitos e fronteiras no Império Português. MOTTA, Márcia; SERRÃO, José Vicente e MACHADO, Marina (Orgs.). Vinhedo. Editora Horizonte, 2013, p. 282. 
Em correspondência do dia 12 de agosto de $1819^{59}$, Frei Ludovico dirige a Balthazar informações sobre o estado de "civilização" dos índios aldeados, bem como sobre o estado produtivo do aldeamento naquele momento. Cinco anos após seu estabelecimento, o aldeamento já contava com plantações de algodão e café, além de mandioca, informações que, segundo o próprio frade, haviam sido solicitadas por Lisboa. Vale ressaltar que, por essa ocasião, Balthazar da Silva Lisboa já não desempenhava o cargo público de ouvidor, visto que permaneceu na função de ouvidor e juiz conservador das matas da comarca de Ilhéus até 1818. Em outra carta, de 29 de outubro de $1820^{60}$, o frade capuchinho novamente respondia às solicitações do antigo ouvidor e a carta gira em torno dos mesmos assuntos da correspondência anteriormente citada.

$\mathrm{Na}$ carta datada de 21 de outubro de 1829, Frei Ludovico de Liorne dirige-se a Balthazar como se ele fosse o "dono" daquele estabelecimento, com as seguintes palavras e informações:

[...] Lhe dou as notícias que V. S. me pede, deste seu estabelecimento de S. Pedro d'Alcântara, que lhe custou tanto trabalho, e quase a vida. [...] A crise política, a ausência de V. S. reduzio problemática a estável permanência desta povoação, na certeza de que se eu faltára, estava tudo acabado. Esta dúvida desanimou os Indios na sua progressiva plantação de café e algodão, como já tinha principiado; e em quanto não houver mais sólida firmeza, vão tendo mão a vida, ocupando-se em serviços de machado, em

59 LISBOA, Balthazar da Silva. Annaes do Rio de Janeiro. Editora Leitura: Rio de Janeiro. Tomo VI. 1835, p. 207-209.

60 Idem, p. 209-211. 
manter as ditas plantas, em caça, em pesca, em cultivar mandioca, e outros vegetaes necessários ao humano sustento ${ }^{61}$.

A citação acima, de fragmentos da carta endereçada a Lisboa, nos permite, além de reforçar a tese de que aquelas terras poderiam pertencer, de fato, a Balthazar, conceber a ideia da presença indígena como estratégia imperiosa para o beneficiamento das terras, pois eles serviam como mão de obra na agricultura. Ressaltamos a atuação dos índios aldeados, principalmente nas lavouras do café e algodão, produtos que não faziam parte do rol de plantações, mas seriam apenas para o abastecimento interno do aldeamento. Fica patente no teor da carta, além disso, que informar o andamento das plantações de café e algodão era a principal preocupação do missionário, pois ele não se esqueceu de escrever que os índios estavam desanimados com a ausência de Lisboa, e se ocupavam mais em serviços da lavoura de subsistência, o que, por sua vez, parecia ser um assunto secundário na correspondência entre eles.

A última das cartas consultadas data de 10 de fevereiro de 1831, momento em que já se encontra avançada a obra da estrada Ilhéus-Conquista. Ela serve de apoio para realçar outro interesse, que permeava o aldeamento como empreendimento voltado ao beneficiamento das terras de Balthazar da Silva Lisboa e do sul da Bahia. Segundo frei Ludovico, o aldeamento estabelecido por Balthazar contribuía muito para o sucesso da estrada. De acordo com o frei, "tenho hospedado todos os passageiros [...] tendo feito com esses índios huma casa, e hum pasto grande [...], feito plantar mandioca bastante, e milho, a fim de prevenir as futuras precisões

61 LISBOA, Balthazar da Silva. Op., cit., p. 212-217. 
dos viajantes"62. Ou seja, a posição geográfica do aldeamento e a produção agrícola dos índios aldeados em Ferradas eram sistematicamente utilizadas para atender à demanda do fluxo de pessoas que por ali transitavam.

A estrada que passava pelo aldeamento de Ferradas era de fundamental importância para o desenvolvimento econômico da região; e supomos que Balthazar tinha clareza da situação quando comprou terras e, subsequentemente, instalou a aldeia de Gueréns e Camacãs naquela localidade. Os índios aldeados deram suporte à abertura e conservação da estrada e isso tornou possível o trânsito de pessoas e mercadorias. Ou seja, a localidade funcionava como um corredor de trânsito regional e tornou-se, posteriormente, uma área visada e valorizada.

\subsection{Atuação dos capuchinhos no Aldeamento São Pedro de Alcântara}

Fr. Ludovico de Liorne que com Zelo verdadeiramente Apostolico, sem attender a fadigas, privações, incomodos, e perigos de vida deliberou-se hir pessoalmente por entre as tenebrosas e assustadoras Mattas da Comarca dos Ilheos em procura de Indios bárbaros e Selvagens, só com o fim sublime da Gloria de Deos e Salvação das almas, e utilidade do Estado, e Nação ${ }^{63}$.

As palavras de Frei Ambrósio de Rocca, prefeito do Convento (Hospício) da Piedade da cidade de Salvador,

62 LISBOA, Balthazar da Silva. Op., cit., p. 217-219.

63 AN; Códice 807; volume 2. Relato de Frei Ambrósio de Rocca - Prefeito do Hospício da Piedade - sobre o estabelecimento dos missionários franceses e italianos na Província da Bahia; 24 de janeiro de 1824, fl. 115. 
Província da Bahia, são reveladoras dos direcionamentos adotados para as populações indígenas na primeira metade do século XIX, na província baiana. Essa política indigenista se assentava nos discursos e práticas coloniais reelaboradas pelos interesses imperiais, e correlacionava catequese, civilização, colonização e integração indígena ao projeto nacional.

Em estudo sobre o Aldeamento São Pedro de Alcântara, Paraná (1855-1895), Marta Rosa Amoroso empreendeu esforço no sentido de delinear as estratégias de contato que envolviam os índios, missionários capuchinhos e outros atores, bem como as ressignificações de instituições ocidentais no processo de adaptação social, política e cultural dos Kaiowá, Guarani e Kaingang ${ }^{64}$. No bojo das leituras que compõem essa parte do trabalho, na qual tentamos condensar, brevemente, algumas ponderações acerca da prática capuchinha no século XIX, o estudo de Amoroso é fundamental para entendermos tal lógica.

Amoroso destaca que, para os capuchinhos, os índios eram incapazes intelectualmente e o aprendizado do modo civilizado só se daria pelo uso da imitação, através da mistura com os não índios nos aldeamentos. "[Os] índios aprenderiam convivendo com a gente católica e trabalhadora do Brasil" ${ }^{\prime 6}$. Na perspectiva de Amoroso, a lógica da catequese capuchinha não atendia a fins estritamente religiosos. Os interesses da conversão da alma dos índios ao cristianismo caminhavam lado a lado com o intento da sua conversão aos "modos civilizados". Para Marta Amoroso, o sentido da catequese ia bem além da

64 AMOROSO, Marta Rosa. Catequese e evasão: Etnografia do aldeamento indígena São Pedro de Alcântara, Paraná (1855-1895). Tese de doutorado. USP: 1998, p. 21.

65 AMOROSO, Marta Rosa. Op., cit., p. 252-253. 
instrução religiosa. A pedagogia da catequese tinha por prioridade moldar o índio para o trabalho e inseri-lo na civilização nacional produtiva. Tratando a realidade de fins do Oitocentos, Amoroso define que "os índios figuravam como trabalhadores individualizados de colônias 'mistas' implantadas no sertão do Brasil, embriões de cidades florescentes." 66

Patrícia Sampaio pontuou que no Pará, Maranhão, Espírito Santo e Ceará as missões capuchinhas atuavam desde as décadas de 1830 e 1840, antes mesmo da execução do Regulamento de $1845^{67}$. Isso evidencia que a convocação à ordem religiosa antecede o Regulamento de 1845 e desfaz a ideia equivocada de que a Ordem só começou a fazer parte da estratégia administrativa da governança indigenista imperial a partir do Decreto $n^{\circ} 426$. Na realidade, a partir de 1845 fica legalmente reconhecido e regulamentado o papel administrativo dos capuchinos nos aldeamentos. Desse modo, Cunha salienta que, quando os "missionários são reintroduzidos no Brasil, na década de 1840, ficarão estritamente a serviço do Estado." ${ }^{\prime 8}$ A partir daí, eles se configuraram em peça chave-para a execução do Regulamento das Missões de Catequese.

Em consonância com a fala de Manuela Carneiro da Cunha, Márcia Malheiros, em seu estudo sobre a atuação capuchinha no Rio de Janeiro nas últimas décadas do século XVIII e decorrer do XIX, define que, com a convocação e a atuação capuchinha, o Império "manteve seu ideário de integração e controle dos nativos e de seus territórios, em

66 Idem, p. 255.

67 SAMPAIO, Patrícia Melo. "Política indigenista no Brasil Imperial". In: GRINBERG, Keila; SALLES, Ricardo (Orgs.). O Brasil Imperial, volume I: 1808-1831. Rio de Janeiro: Civilização Brasileira, 2009, p. 180.

68 CUNHA, Manuela Carneiro da. Op. cit., p. 134. 
nome de uma 'causa maior': a expansão da cristandade, a concretização da empresa colonial ou integração, segurança e desenvolvimento do Estado-nação" ${ }^{69}$.

A entrada da administração religiosa capuchinha nos aldeamentos não ocorreu de forma casual, nem, tampouco, foi uma medida isolada de cada província, mas antes resultado de amplo processo de debate e disputa político-parlamentar da década de 1840. A questão envolvia a relação entre Estado e Igreja e dividia as opiniões. Januário da Cunha Barbosa defendia a necessidade do emprego da catequese e missão nas regiões mais afastadas do Império, ou seja, nos espaços ainda não considerados "civilizados". Desse ângulo, a "vinda dos missionários incidira diretamente sobre a estratégia de catequese e civilização dos índios, que o governo tratava como um 'ramo do serviço público" ". ${ }^{70}$

Gonçalves de Magalhães também participou do debate e ressaltava que a ação do Estado deveria caminhar ao lado da ação moralizadora da religião. No entanto, esta proposta deixava claro que a entrada dos missionários capuchinhos no Brasil e sua atuação estariam subjugadas ao governo imperial, demonstrando que o Estado tinha total autonomia diante da ordem religiosa no projeto de catequese dos índios em andamento ${ }^{71}$. Segundo lei maranhense de 1839, os "capuchinhos italianos ficam inteiramente a serviço do governo, que os distribui segundo seus próprios

69 MALHEIROS, Márcia. “Homens da fronteira”. Índios e capuchinhos na ocupação dos sertões leste do Paraíba ou Goytacazes século XVIII e XIX. Tese de doutorado. Universidade Federal Fluminense, Niterói: Rio de Janeiro, 2008, p. 13.

70 KODAMA, Kaori. Os índios no Império do Brasil: a etnologia do IHGB entre as décadas de 1840 e 1860. Rio de Janeiro: Editora FIOCRUZ; São Paulo: EDUSP, 2009, p. 244.

71 KODAMA, Kaori. Op., cit, p. 248. 
projetos"72. Nesses termos, ressalta Cunha, a atuação capuchinha não tinha a mesma autonomia jesuítica "em relação aos projetos governamentais e aos interesses dos moradores, que vigorou em alguns períodos coloniais." ${ }^{73}$

$\mathrm{Na}$ mesma linha, Kaori Kodama demonstra que a atuação missionária capuchinha estava subjugada às diretrizes governamentais do Império do Brasil. Ressalta que a "decisão de importar frades italianos não era, portanto, algo isolado, mas um dos passos que conduziam à busca de uma definição geral da política indigenista, cuja discussão (...) já possuía uma longa trajetória"74.

No Regulamento das Missões de Catequese de 1845, os missionários religiosos tinham, em tese, suas atividades restringidas às funções religiosas. No entanto, como bem ressaltam Cunha $^{75}$ e Kodama ${ }^{76}$, tais atribuições não eram as únicas exercidas pelos frades missionários. Na realidade do aldeamento, era o missionário quem, recorrentemente, assumia todas as funções do aldeamento, inclusive as administrativas. Jerônimo Francisco Coelho, presidente do Grão-Pará em 1849, destacava que "só os missionários poderiam ocupar-se da tarefa de administrar as aldeias e representar os índios, uma vez que havia 'catequese e civilização' dos índios apenas onde estavam presentes os missionários, e de outra forma só haveria opressão e trabalho forçado". ${ }^{77}$

A atuação dos missionários capuchinhos italianos no sul da Bahia se dá desde o início do século XIX.

72 CUNHA, Manuela Carneiro da. Op. cit., p. 140-141.

73 Idem, p. 140.

74 KODAMA, Kaori. Op., cit, p. 249.

75 CUNHA, Manuela Carneiro da. Op. cit., p. 140.

76 KODAMA Kaori. Op., cit. p.250.

77 Ibidem. 
A documentação indica que Frei Ludovico foi o primeiro missionário capuchinho italiano a administrar o aldeamento de Ferradas e chegou à localidade em 1818, pois, em carta redigida pelo prefeito do Hospício da Piedade, em 1824, é mencionado que o frade estava à frente do aldeamento havia 6 anos $^{78}$.

A despeito da escolha de secularização da administração dos aldeamentos a partir do Diretório pombalino, como frisou Cunha, na legislação de 1845, o Império optou pela administração leiga. Entretanto, tal opção se apresentou de forma ambígua, visto que os religiosos, recorrentemente, acresciam ao cargo de missionário, o de diretor da aldeia ${ }^{79}$. Kodama observou que, em muitos casos, por falta de diretores (leigos) competentes, era o missionário que assumia a administração do aldeamento ${ }^{80}$. Portanto, na prática e na maioria das vezes, o missionário assumia o posto de religioso e diretor do estabelecimento. Em São Pedro de Alcântara não foi diferente. Por meio da observação das correspondências trocadas entre autoridades religiosas e governamentais locais e a presidência da Província, verificamos que o aldeamento foi administrado quase exclusivamente por missionários, como se pode conferir na Tabela 1.

78 AN; Códice 807; volume 2. Relato de Frei Ambrósio de Rocca - Prefeito do Hospício da Piedade - sobre o estabelecimento dos missionários franceses e italianos na Província da Bahia; 24 de janeiro de 1824, fl. 115.

79 CUNHA, Manuela Carneiro da. Op., cit., p. 140.

80 KODAMA, Kaori. Op., cit., p. 250. 
TABELA 1 - Administradores do aldeamento São Pedro de Alcântara entre os anos, 1818-1861

\begin{tabular}{|l|l|l|}
\hline PERÍODO & MISSIONÁRIO & DIRETOR \\
\hline $1818-1848$ & $\begin{array}{l}\text { Fr. Ludovico de } \\
\text { Livorno (Liorne) }\end{array}$ & $\begin{array}{l}\text { Frei Ludovico de } \\
\text { Livorno }\end{array}$ \\
\hline $1849-1853$ & $\begin{array}{l}\text { Fr. Vicente Maria de } \\
\text { Ascolis }\end{array}$ & $\begin{array}{l}\text { Fr. Vicente Maria de } \\
\text { Ascolis }\end{array}$ \\
\hline $1854-1855$ & $\begin{array}{l}\text { Fr. Francisco Antônio } \\
\text { de Falerna }\end{array}$ & $\begin{array}{l}\text { Fr. Francisco Antônio } \\
\text { de Falerna }\end{array}$ \\
\hline 1856 & $\begin{array}{l}\text { Fr. Vicente Maria de } \\
\text { Ascolis }\end{array}$ & $\begin{array}{l}\text { Fr. Vicente Maria de } \\
\text { Ascolis }\end{array}$ \\
\hline 1858 & Fr. Rainero de Ovada & Fr. Rainero de Ovada \\
\hline 1859 & $\begin{array}{l}\text { Coronel Egídio Luís } \\
\text { de Sá }\end{array}$ \\
\hline 1860 & Fr. Luís de Grava ${ }^{81}$ & $\begin{array}{l}\text { Coronel Egídio Luís } \\
\text { de Sá }\end{array}$ \\
\hline 1861 & & \\
\hline
\end{tabular}

Fonte: Arquivo Público do Estado da Bahia, Arquivos Coloniais e Provinciais, maços: 2395-I, 2396, 4610, 4612, 4613. ${ }^{81}$

\section{A função dos missionários no Aldeamento São Pedro de Alcântara não diferia das práticas implementadas em}

81 Segundo as observações do historiador Pietro Vittorino Regni, em Os capuchinhos na Bahia, uma contribuição para a história da Igreja no Brasil, Frei Luís de Grava assumiu a administração do aldeamento em substituição a Rainero de Ovada a partir de 1860. Observamos que em correspondência de 1859, Egídio de Sá solicita ao governo provincial um novo missionário, por ocasião da saída do frei Rainero de Ovada. Embora não tenhamos encontrado nenhuma correspondência assinada pelo referido missionário substituto, visto que, depois dessa data, a documentação compilada não faz mais menção ao aldeamento, e sim à colônia agrícola de nacionais, ali estabelecida e dirigida por frei Luís de Grava, a fala do presidente da Província da Bahia, de $1^{\circ}$ de abril de 1860, confirma a nomeação de Luís de Grava, conforme solicitação de Egídio de Sá. 
nível nacional ${ }^{82}$. Grosso modo, podemos elencar: trabalhar os valores religiosos católicos, promovendo batismos e matrimônios; introduzir no aldeamento os modos de vida do branco, bem como incentivar e moldar os índios à rotina do trabalho sistemático para os serviços públicos e particulares.

A fala de Frei Ludovico sobre o andamento do seu trabalho em São Pedro de Alcântara é bem explícita quanto ao papel desempenhado pelos missionários no aldeamento. Em correspondência de 1820, ele registra: “(...) espero que com a constancia e paciência, que Deos me der, hei de vencer outras difficuldades, e reduzilos todos ao bom caminho da Religião, e vassallagem fiel"1"83.

No conjunto das correspondências levantadas sobre o aldeamento, observou-se que os assuntos predominantes eram quase sempre os mesmos: segurança, trabalho, catequese, civilização, colonização. Entretanto, vale ressaltar que, no total das correspondências, bem poucas são das décadas de 1820 e 1830, pois a quase totalidade delas são das décadas de 1840 e 1850. Existe um hiato, portanto, na documentação, mas isso não inviabiliza uma análise que apreenda com certa precisão as demandas administrativas estabelecidas em São Pedro de Alcântara, pois, por meio da documentação disponível, pode-se perceber os fluxos das demandas do aldeamento até 1845 , bem como os assuntos pautados na segunda metade do século (ver a Tabela $n^{\circ}$ 5, Anexo 3).

As comarcas do sul da província da Bahia despertavam maior interesse do governo por dois motivos: era a

82 Sobre o papel dos capuchinhos no processo de catequese nos aldeamentos ver: CUNHA, Manuela Carneiro da (1992); KODAMA, Kaori (2009); MALHEIROS, Márcia (2008).

83 LISBOA, Balthazar da Silva. Annaes do Rio de Janeiro. Editora Leitura: Rio de Janeiro. Tomo VI. 1835, p. 210. 
região mais habitada por populações indígenas, merecendo, assim, atenção governamental no sentido de integrar os índios à civilização e pelo fato de aquela região se apresentar como propensa fronteira de expansão e desenvolvimento agrícola e econômico da província. Desse modo, por volta de 1870, ao contrário do norte da província, onde a orientação era extinguir os aldeamentos por considerar os índios já misturados aos nacionais, o sul chamava a atenção das autoridades, que intensificavam as medidas políticas voltadas para populações indígenas daquela região, na segunda metade do século XIX, haja vista a seguinte orientação:

Indios que devem ser cathequizados, só os há propriamente no sul da província; os mais tem seu princípio de civilização e estão misturados com a população das localidades; por isso manda o director que seria conveniente mandar vender as terras das aldeias, que já não tem índios, e naquellas em que restam alguns, reservar datas de terras, medidas e demarcadas, que lhes sejam distribuídas ${ }^{84}$.

Contudo, nas décadas finais do século XIX, a política direcionada a atender o problema indígena na região sul da Bahia diferia da política empreendida no início do XIX. Naquele momento, em virtude de maiores interesses acerca do trabalho e das terras indígenas para atender aos interesses da lavoura do cacau, o foco do governo se desloca dos aldeamentos, prioritariamente, para o estabelecimento das

84 Fala do presidente da província da Bahia na abertura da Assembleia Legislativa, $1^{\circ}$ de março de 1872, p. 145. In: Falas e Relatórios Provinciais Presidenciais (1830-1930). Disponível em: <http: / / www.crl.edu / brazil/provincial/bahia $>$. 
colônias nacionais agrícolas, mas essa questão será trabalhada em outro capítulo.

No processo de maiores interesses governamentais pelo funcionamento dos aldeamentos, Telma Moreira de Souza observa que a relevância do trabalho capuchinho na região sul da Bahia lhes conferia certa autonomia diante do governo e justificava a acumulação de cargos de diretor e missionário das aldeias ${ }^{85}$. Além disso, a autora ressalta que os capuchinhos "agiam como funcionários do governo, solicitando aumento de salários, pagamento de gratificações, comparando seus salários ou exigindo tratamento igualitário com relação a outro missionário que acusavam de receber tratamento privilegiado do diretor geral" 86 .

Márcia Malheiros ressalta que os estudos acerca das missões de catequese indígena do século XIX não contam com uma profusão de documentação semelhante à encontrada para os estudos coloniais, visto que, ao contrário dos missionários jesuítas que produziram uma ampla massa de documentação com relação a sua experiência catequética, os frades capuchinhos pouco registraram sua atuação religiosa e administrativa nos aldeamentos durante o século XIX. Dessa forma, muito do que se pode inferir sobre a história e as relações entre índios e missionários se consegue a partir de uma leitura, muitas vezes, atenta e a contrapelo da documentação oficial produzida pelo intercâmbio de autoridades locais e autoridades provinciais. Tendo em vista os escritos dos missionários sobre a realidade dos aldeamentos e as relações estabelecidas naqueles espaços, consideramos importantes as cartas trocadas

85 SOUZA, Telma Moreira de. Op., cit., p. 167.

86 Idem, p. 174. 
entre o missionário Ludovico de Livorno e Balthazar da Silva Lisboa, transcritas nos Annaes do Rio de Janeiro ${ }^{87}$.

Estas cartas trocadas entre Ludovico e Lisboa nos permitem afirmar o estreitamento das relações entre Balthazar, responsável pela fundação do aldeamento São Pedro de Alcântara, em Ferradas, e frei Ludovico. Destacaremos, em nossa análise, especialmente, a administração de Ludovico de Livorno pelo fato de ele ter exercido as funções de religioso e diretor do estabelecimento por três décadas, bem como em razão da relevância social adquirida pelo missionário na região, papel e lugar que é recorrentemente frisado e elogiado nas correspondências oficiais do período.

Balthazar exerceu o cargo de ouvidor da comarca de Ilhéus de 1797 a $1818^{88}$. No contexto de troca da primeira carta identificada (1819), ele não era mais ouvidor e tampouco residia na região, haja vista Ludovico mencionar sua ausência e combinar um encontro com ele na ocasião de sua estadia em Rio de Contas. Apesar disso, em todas as cartas o missionário evidencia que as informações eram prestadas por demanda de Balthazar.

$\mathrm{Na}$ primeira carta, Frei Ludovico se refere às acomodações do aldeamento, demografia e situação de deserção por conta de doenças, e explicita que, nessa ocasião, muitos dos aldeados haviam morrido. Relata o missionário que:

87 LISBOA, Balthazar da Silva. Annaes do Rio de Janeiro. Editora Leitura: Rio de Janeiro. Tomo VI. 1835. Nas referidas correspondências, e na escrita regional, ressaltamos que a atuação de Ludovico é descrita como essencial para o êxito da política de aldeamento naquela região. Além disso, é importante observar que a atuação indígena aparece nos relatos do frade à Balthazar e, por isso mesmo, as cartas identificadas são fundamentais para a construção dos nosso objeto de estudo.

88 MARCIS, Teresinha. Op., cit., p.184. 
Os Indios civilisados de Almada são em numero de treze famílias, que formão treze casas arruadas defronte do Templo, que V. S. fez; atraz da Igreja estão as casas dos Camacães em quadrado, que formão huma bonita praça, onde moravão em numero de cento e vinte, porém a moléstia e mortandade, que tiverão neste anno, os obrigou de ir no interior para se curar, e actualmente aqui são poucos, os quaes vão e vem desconfiados do sitio ${ }^{89}$.

No trecho citado acima, fica em evidência que os Camacãs, embora estivessem coabitando um mesmo espaço de territorialização dos Guerens, de certa forma mantinham suas fronteiras étnicas, já que o administrador do aldeamento dispunha de dois núcleos distintos de moradia para ambas as etnias. Nessa perspectiva, lembramos que Frederik Barth ${ }^{90}$ define a fronteira étnica como um processo relacional, isso significa dizer que os sujeitos se identificam etnicamente na interação, organizando-se frente ao seu oposto.

Em São Pedro de Alcântara, os guerens e camacãs construíram espaços próprios e diferenciados, mas próximos entre si, como sugere o relato acima sobre a localização de cada etnia dentro do mesmo espaço de aldeamento. Certamente, as distinções étnicas de cada grupo obrigavam as autoridades a construir espaços díspares para aqueles homens em "situação de aldeamento". Convém ressaltar que não se sabe, por meio da documentação disponível, por quanto tempo existiram as fronteiras étnicas entre eles ou se, no longo prazo, eles terminaram

89 LISBOA, Balthazar da Silva. Op., cit., p. 207-209.

90 BARTH, Frederik. "Grupos étnicos e suas fronteiras". In: POUTIGNAT, Philippe; STREIFF-FENART, Jocelyne. Teorias da etnicidade: seguido de grupos étnicos e suas fronteiras. 2. ed. São Paulo: Ed. UNESP, 2011. 
por se misturar. A bibliografia especializada, a exemplo da de Celestino de Almeida e de Pacheco de Oliveira, sinaliza, contudo, que a territorialização de índios de diferentes etnias em nada prejudica o fato essencial de que o espaço do aldeamento acaba se tornando um território reconfigurado pelos próprios índios aldeados, misturados ou não, tornando-se, para além de um espaço do colonizador, também um espaço de pertença dos índios. Essa discussão será objeto do quarto capítulo.

O fragmento citado acima também nos possibilita perceber o trânsito dos indígenas aldeados, visto que a descrição de que eles "vão e vêm" nos permite supô-los ainda exercendo sua autonomia no processo de aldeamento. Os índios partiam para o interior para se curar das enfermidades. Isso permite inferir que, além de se disporem a viver no espaço territorializado pelo branco, pois saíam e retornavam ao aldeamento, eles ainda tinham acesso aos sertões. Além disso, se partiam "para o interior para se curar", é porque não haviam perdido suas referências e códigos culturais, pois recorriam às suas práticas religiosas e de cura num espaço social distinto do aldeamento. Contudo, mais importante é observar que os Camacãs e os guerens de São Pedro de Alcântara transitavam com certa liberdade em uma fronteira que era fluida, espaço social de interações e de crescente ressignificações.

Dispomos de uma consolidada nova historiografia indígena que tem, entre outros expoentes, Manuela Carneiro da Cunha, Maria Regina Celestino de Almeida, John Manuel Monteiro, Vânia Losada Moreira, na qual os indígenas em "situação de aldeamento" são vistos como sujeitos ativos de sua história. Apesar disso, é inegável o caráter negativo das políticas indigenistas exercidas sobre as populações indígenas ao longo do processo colonizador no Brasil colonial e imperial, que modificaram, até mesmo 
com evidente violência, o curso da história e das vontades desses povos. Dessa forma, em carta datada de 29 de outubro de 1820, frei Ludovico descreve a Lisboa a resistência dos índios associada a um passado que ainda se fazia presente naquelas paragens: a prática do trabalho escravo. Ludovico de Livorno escreve:

\begin{abstract}
[...] Saiba V. S., que eu até agora não estava bem satisfeito delles, por causa da desconfiança em que elles vivião de nós, fundada na tradição de seus antecessores, que os Portuguezes erão seus inimigos, e que os nossos mesmos erão dirigidos a engana-los, e reduzi-los nossos captivos, a qual desconfiança augmentava-se pelo modo com que alguns tratava, e vai ainda tratando com elles, fazendo-os trabalhar quase por força, com ameaça do castigo, e sem nenhum lucro para elles $[\ldots]^{91}$.
\end{abstract}

O conteúdo da carta é revelador: a escravização ilegal dos índios era ainda prática corrente naquela região, bem como a memória e o receio dos índios em relação a isso, taxando como "inimigos" todos os que queriam reduzi-los ao cativeiro. O sul da Bahia despertava o interesse de assentamento de colonos e, nesse processo, o índio era importante tanto como pacificador do território, quanto para servir de mão de obra. Ainda que o Diretório pombalino tenha legalizado o uso do trabalho indígena, estabelecendo a contrapartida de pagamento do serviço prestado, e tendo em vista que, naquele momento, o que vigorava eram decretos, alvarás, resoluções que mantiveram a liberdade dos índios, a documentação testemunha que a prática, no sul da Bahia, era bem diferente. Como bem frisou Manuela Carneiro da

91 LISBOA, Balthazar da Silva. Op., cit., p. 209-211. 
Cunha, "a escravidão indígena perdurou surpreendentemente até pelo menos os meados do século XIX"92.

Outra informação muito importante é o indício de que o aldeamento parecia funcionar como apoio para a formação ou manutenção de outros aldeamentos, pois os indígenas circulavam de forma itinerante pela região. Ao se referir ao decréscimo da população do aldeamento de Ferradas por conta de doenças, frei Ludovico ressalta que os "outros Camacães, que não he pequeno numero, estão aldeados quatro legoas mais para cima, onde não estão sugeitos ás doenças do sitio." ${ }^{\prime 3}$ Ou seja, os aldeados de São Pedro de Alcântara não viviam exclusivamente em Ferradas, e tampouco aquele aldeamento era o único lugar indígena da região.

Em outra carta, datada de 21 de outubro de 1829, que o frade escreve para Balthazar, a quem ele serve como "amigo e criado", segundo palavras do próprio Ludovico, ele segue sua narrativa prestando conta da situação do aldeamento:

[...] Os ditos selvagens, depois de estarem aqui reunidos, cahirão todos doentes, e huma grande parte delles morrerão, de sorte que atemorisados os que ficárão, concentrãose novamente nas suas brenhas, e eu com poucos Indios de Almada fiquei aqui hum anno, sem ter noticia delles. No entanto Deos me deu Constancia, tornei a convida-los, e parte delles vierão, e os outros mais medrosos formarão huma aldêa distante daqui dous dias de viagem, porém todos mansos, e em recíproca correspondência comnosco, e em termo de reuni-los facilmente, quando

92 CUNHA, Manuela Carneiro da. Op. cit., p. 146.

93 LISBOA, Balthazar da Silva. Op., cit., p. 209-211. 
for tempo. Actualmente me acho aqui com noventa e seis indivíduos, e cincoenta na visinha aldêa, esperando a resulta das medidas que o Governo tem tomado acerca do novo abrimento da estrada, e das colônias estrangeiras $[\ldots]^{94}$.

Novamente verificamos o trânsito dos Guerens e Camacãs entre os dois mundos: o mundo que eles tinham por referência social até aquele momento e o mundo do aldeamento, espaço reconfigurado por suas experiências cotidianas. A descrição de frei Ludovico é muito rica para o que pretendemos observar. Permite perceber aquelas pessoas em "situação de aldeamento" como agentes de sua trajetória histórica, vivendo as mazelas da conquista, como as epidemias, mas sem perder, contudo, um relativo controle sobre suas vidas. Ao mesmo tempo em que podemos visualizar os índios de Ferradas agindo com certa autonomia sobre suas vidas, apesar das doenças e de outras dificuldades, percebemos, em contrapartida, a atuação missionária como braço do Estado imperial e dos interesses privados naquela região.

No processo de colonização regional, frei Ludovico estabelece uma teia de comunicações entre diferentes pontos da localidade próxima ao Aldeamento São Pedro de Alcântara. Tal estratégia converge para o próprio propósito de tornar a região pacificada e habitada por colonos. Dois dos pontos que aparecem ao final do fragmento documental citado acima dizem respeito à abertura da estrada IlhéusConquista e à instalação de colônias de estrangeiros na região. Ambas são demandas da política imperial e tinham como fim tornar aquele território habitável e transitável.

94 LISBOA, Balthazar da Silva. Op., cit., p. 214-217. 
Nesse processo, era central controlar os indígenas, pacificá-los, aldeá-los e, de preferência, ainda pô-los a serviço da estrada e dos novos moradores.

Novamente emerge, nessa correspondência entre Ludovico e Balthazar, a divisão dos índios em diferentes aldeamentos. A carta de frei Ludovico sugere que existia um aldeamento oficial, que era Ferradas, cercado por outras aldeias ou aldeamentos. Os índios aldeados em São Pedro de Alcântara, em contextos específicos, dividiam-se e ocupavam outra área próxima ao estabelecimento administrado pelo missionário. Não se pode afirmar que aqueles grupos subdivididos fundavam, na verdade, outro aldeamento; ou se eram aldeias com ramificações em Ferradas, pois o frade não fornece informação suficiente. $O$ mais plausível é interpretar o aldeamento de Ferradas como tendo um núcleo dirigido pelo frei e muitos outros lugares (aldeias) onde os índios viviam de forma mais autônoma, mas sem perder a conexão com o frei e com Ferradas.

Ao final da carta citada, a fala de frei Ludovico novamente nos põe diante dos Camacãs e Guerens de Ferradas como atores que mantinham certa autonomia sobre suas vidas no mundo territorializado: "Respeito á educação moral e civil destes Indios não posso estender minhas vistas acima da capacidade delles, e fóra dos limites destes bosques, pois a experiência me tem feito ver, que fora daqui ficão cheios de vícios, voltão vadios e mestres de impiedade" ${ }^{\prime \prime 5}$. Portanto, nos deparamos novamente com as ideias de Oliveira: o "processo de territorialização não deve ser jamais entendido simplesmente como de mão única, dirigido externamente e homogeneizador" ${ }^{\prime \prime 6}$.

95 LISBOA, Balthazar da Silva. Op., cit., p. 214-217.

96 OLIVEIRA, João Pacheco de. Op., cit., p. 60. 
Ainda segundo João Pacheco de Oliveira, o processo de territorialização deve ser entendido como um processo de via dupla, onde também os índios participam ativamente. Assim, embora os índios se encontrassem num contexto delimitado pelo estado e em situação de homogeneização, na qualidade de índios aldeados, esse espaço sofre ressignificação, na qual os índios são capazes de construir novas identidades étnicas que são evocadas conforme o contexto vivido ${ }^{97}$. Desse modo, os índios, apesar da pressão homogeneizante exercida pela política de aldeamento e catequese, resistem e constroem fronteiras fluidas entre os dois mundos: o mundo do aldeamento dirigido pelo frei, e o mundo de suas aldeias mais ou menos independentes do projeto colonizador. O intercâmbio se dá, além disso, conforme seus interesses, necessidades e as possibilidades de cada momento.

O estudo de Amoroso nos ajuda a entender o movimento entre aldeamento, aldeia mais ou menos independente do centro do aldeamento e sertão. A realidade dos aldeados de São Pedro de Alcântara, no Paraná, estudados por Marta Amoroso, se aproxima da realidade de São Pedro de Alcântara, no sul da Bahia. A autora observa, na documentação utilizada, os termos "círculo urbano" e "aldeias dos índios". Isso significava dizer que os aldeados

97 Idem, p. 56. Na mesma direção de Oliveira, outros autores, a exemplo de Maria Regina Celestino de Almeida $(2001 ; 2013)$ e Vânia Losada Moreira (2010; 2011), trataram da questão da construção da identidade do índio no mundo territorializado, processo no qual as fronteiras étnicas entre aldeados e colonizadores são mantidas na interação entre os dois mundos. Nesse bojo de reflexão teórica sobre a etnicidade, são fundamentais os direcionamentos teóricos de Frederik Barth* como referência fundamental para pensar a ideia de fronteira étnica entre os grupos sociais em situação de contato. *Grupos étnicos e suas fronteiras. In: POUTIGNAT, Philippe; STREIFF-FENART, Jocelyne. Teorias da etnicidade: seguido de grupos étnicos e suas fronteiras. 2. ed. São Paulo: Ed. UNESP, 2011. 
mantinham um trânsito entre o centro administrativo do aldeamento, do qual participavam e se serviam, e as aldeias distantes do centro administrativo, aldeias que abrigavam as distintas etnias: Guaranis, Kaiowás e Kaingangs 98 .

Para Amoroso, a historiografia teria forjado a ideia de que os aldeamentos do Império foram "instituições falidas" e não teriam impactado as populações indígenas, que se mantiveram afastadas. Ao contrário disso, através da ideia da "territorialidade indígena pós-aldeamento", ela percebe o distanciamento mantido pelos índios no processo de contato, e empreende algumas reflexões acerca da evasão dos índios dos aldeamentos, e os dois movimentos são igualmente verdadeiros: a evasão dos índios, bem como sua presença nos aldeamentos paranaenses, criados no século XIX. A autora toma a ideia da análise "multilocal", de Marshall Sahlins, e analisa a atuação dos aldeados transitando dentro e fora do aldeamento, bem como as relações estabelecidas entre esses e os índios não aldeados, como processo de adaptação sociocultural e política das populações que gradativamente apropriavam-se e ressignificavam as instituições ocidentais ${ }^{99}$. Em outras palavras, eles ressignificavam o território imposto pela colonização em um novo espaço de territorialidade, o que Amoroso denomina de "territorialidade indígena pós-aldeamento".

O estudo de Amoroso, nesse sentido, contribui, sobremaneira, para pensarmos a existência do trânsito dos aldeados de Ferradas e a existência das aldeias afastadas do centro do aldeamento. Não notamos, na documentação disponível, a divisão, dessas aldeias independentes do

98 AMOROSO, Marta Rosa. Op., cit., p. 92.

99 Idem, p. 90. 
centro, em etnias demarcadas, ou seja, aldeias separadas uma das outras que abrigassem as distintas populações, subgrupos ou facções, contudo, em certa medida, a realidade de Ferradas se aproxima da situação de fronteira étnica observada no estudo de Amoroso para o Aldeamento São Pedro de Alcântara. Na realidade estudada por ela, as fronteiras entre as diferentes etnias foram rigidamente mantidas no interior do aldeamento, assim como em Ferradas (o centro administrativo do aldeamento), as distintas etnias: os camacãs e os Guerens habitavam em moradias rigidamente separadas, no interior do Aldeamento São Pedro de Alcântara, nos primeiros anos do seu funcionamento.

A ideia de "territorialidade pós-aldeamento" direciona a compreensão de que uma nova territorialidade, envolvendo o aldeamento e o sertão, se construía em Ferradas a partir da realidade de contato e interação. Os aldeados de Ferradas circulavam entre o centro administrativo do aldeamento e as aldeias afastadas do centro, as aldeias mais ou menos independentes, bem como conviviam, nos perímetros do aldeamento, com índios Pataxós não aldeados. Um processo contínuo de ressignificação do sentido do território era construído pelos índios em "situação de aldeamento" e também por aqueles que não eram aldeados, mas que viviam a experiência da colonização na convivência que tinham nos arredores do aldeamento.

Na última carta enviada por Ludovico de Livorno a Silva Lisboa, em fevereiro de 1831, são tratados temas que se tornaram centrais na pauta parlamentar do período, acerca dos direcionamentos para a política indigenista do Império do Brasil: estrada, mão de obra e colonização. Especificamente sobre os direcionamentos provinciais para o sul da Bahia, identificamos a questão do comércio regional. Nesse processo dos acontecimentos, Ludovico tece a seguinte descrição: 
[...] Por tanto participo a V. S. que esta estrada, faz poucos mezes, está novamente aberta, e neste pouco tempo tem vindo dos Sertões para Ilhéus três boiadas, e vários negociantes com diferentes objectos, para experimentar seus negócios, os quaes têem regressado muito satisfeitos pela commoda visinhança [...]. Esta povoação de Indios, que V. S. estabeleceu neste centro, tem contribuído muito ao bom sucesso desta nova estrada [...] Tenho hospedado todos estes passageiros do melhor modo possível, tendo feito com estes Indios huma casa, e hum pasto grande na beira da estrada á margem deste rio, tenho feito plantar mandioca bastante, e milho, a fim de prevenir as futuras precisões dos viajantes, e continuar tudo em boa ordem. Veremos o progresso, e, se Deos nos der vida, darei a V.S. as respectivas noticias mais a miúdo ${ }^{100}$.

Diferentemente do conteúdo das cartas anteriores, essa última tem como tema central a questão do trabalho indígena e sua atuação na estrada, tanto como conservadores dela quanto como produtores de alimentos para o sustento de tropas e de viajantes. O serviço público de abertura e manutenção da estrada representou, durante todo o século XIX, uma das demandas principais do projeto imperial de colonização naquela região, pois se tratava de uma área que deveria funcionar como corredor de comércio e escoamento de produtos. $\mathrm{O}$ aldeamento de Ferradas estava, estrategicamente, instalado naquelas paragens, e a atuação dos aldeados era vital para o bom êxito daquele projeto.

100 LISBOA, Balthazar da Silva. Op., cit., p. 217-219. 
Igualmente importante era a atuação do aldeamento enquanto ponto de apoio para viajantes e fornecedor de produtos de subsistência. Sendo assim, o bom funcionamento da estrada e o trânsito comercial se configuravam em estratégias correlacionadas para tornar habitada por colonos aquela região, atraídos não só pelo emergente comércio entre Ilhéus, Conquista e Minas, mas, sobretudo, pelo crescente interesse pela lavoura do cacau, que já atraía a atenção de colonos estrangeiros e nacionais para aquelas terras do sul da Bahia.

Nesse processo colonizador, ressaltamos a consolidação do Núcleo Cachoeira de Itabuna que, segundo a bibliografia regional, compreende atualmente o município de Itabuna ${ }^{101}$, e teve suas terras ocupadas e exploradas pelos colonos lavradores de cacau. Formaram-se em Itabuna grandes latifúndios da cacauicultura e ela se tornou um dos polos mais importantes da lavoura e exportação de cacau na Bahia. Apenas como ilustração, lembramos que no antigo hino de Itabuna, a cidade ostentava o título de "Rainha da Bahia", a fim de expressar sua representatividade econômica e social no Estado. Realidade possível, primeira e principalmente, pela atuação do aldeamento de Ferradas, que seria extinto no final da década de 1860.

A documentação deixa poucas, mas evidentes pistas de que sobre o antigo aldeamento foi constituída a Colônia Nacional da Cachoeira de Itabuna, que deu continuidade

101Em Crônica da capitania de São Jorge dos Ilhéus, João da Silva Campos, páginas 380-381, observa que: "Mais ou menos em 1860, começou a ser povoado o sítio em que hoje se ergue a cidade de Itabuna, conforme um anuário nela publicado (713), sendo os seus primeiros moradores quase todos sergipanos. Em princípio de 1861 já a câmara de Ilhéus pedia a criação de um distrito policial em Cachoeira de Itabuna, zona onde existia grande pupulação, não somente de naturais do município, como do centro e do norte da província, e de Sergipe que para ali afluíam desde alguns anos atrás". 
ao papel desenvolvido antes pelo extinto aldeamento. Nos registros do Arquivo Histórico Nossa Senhora da Piedade (OFMCap.), Salvador-Bahia, sobre as missões capuchinhas na Bahia, existe o seguinte registro datado de 1926, acerca de uma missão realizada no local de funcionamento da Colônia: "Nesta missão houve pouquíssima concurrencia por ser um logar quase deserto. Este logar foi outrora aldeamento dos [Camacans]"102. O que denota, muito provavelmente, a sobreposição da Colônia ao aldeamento de Ferradas ${ }^{103}$.

As cartas de Ludovico endereçadas a Balthazar, nas primeiras décadas do século XIX, narrando os primeiros anos da atuação do aldeamento São Pedro de Alcântara, demonstram, dentre outros aspectos importantes, aquilo que João Pacheco sinaliza para se pensar o processo de territorialização de modo mais geral, como um processo de mão dupla, no qual entendemos que coexiste a atuação dos índios aldeados e das autoridades que se ocupavam na empreitada de aldeá-los. Nas mesmas cartas, também fica registrada a atuação dos indígenas aldeados no processo de ocupação e exploração daquele território, projeto que, no sul da Bahia, terminou por viabilizar a implantação da lavoura do cacau.

102 OFMCap: Arquivo Histórico Nossa Senhora da Piedade; Caixa Ea-2; Missões - Colônia de Itabuna; ano 1926; p.279.

103 O fragmento citado está fora do marco temporal delimitado para esta pesquisa, no entanto, se faz pertinente citá-lo pela relevância da informação trazida. Não se sabe se o termo empregado na documentação: "Colônia de Itabuna", faz apenas alusão à colônia agrícola ali instalada na década de 1870 ou se o nome permanece após sua extinção, o fato é que o fragmento citado e a sequência do relato do documento deixam evidente que aquela localidade foi, em momento anterior, o aldeamento dos índios de Ferradas. 


\section{CAPÍTULO III}




\section{TERRITORIALIZAÇÁO E TRABALHO: ATUAÇÁO DOS ALDEADOS DE FERRADAS NOS SERVIÇOS PÚBLICOS E PARTICULARES}

As populações indígenas em "situação de aldeamento" no sul da Bahia, durante o século XIX, ainda têm sido objeto de poucos estudos da historiografia regional, no sentido de pensar suas experiências históricas na dinâmica da formação e consolidação econômica e social da referida região.

A política indigenista de fins do Setecentos, bem como a política do Oitocentos foram marcadas por dois objetivos bastante claros e correlacionados: ocupação territorial e mão de obra indígena. $\mathrm{O}$ trabalho dos homens e mulheres aldeados em Ferradas foi amplamente utilizado, durante quase todo o século XIX, nos serviços, públicos e particulares, voltados ao estabelecimento de pequenos colonos e grandes fazendeiros na região, à abertura e conservação da estrada que ligava as vilas Ilhéus e Vitória (hoje Vitória da Conquista), cujo funcionamento incidia diretamente nos contornos econômicos da região.

O sul da Bahia configurou-se, no decorrer do Oitocentos, em "região cacaueira". Nesse processo, o trabalho dos homens e mulheres dos aldeamentos instalados, à época, foi de extrema importância para a nova conformação social, política e econômica regional. No entanto, a narrativa memorialista desconhece ou, pior ainda, propositalmente esconde a presença dos índios na formação da economia 
e sociedade regionais, alegando que a formação da atual Itabuna se deve ao trabalho pioneiro dos migrantes sergipanos, processo no qual os índios, quando são mencionados, o são como estorvo ao progresso e um obstáculo superado pela coragem dos pioneiros. O objetivo deste capítulo é demonstrar a atuação do trabalho dos aldeados de Ferradas nos ramos dos serviços públicos e particulares, com especial atenção para a utilização da mão de obra indígena nos trabalhos da estrada Ilhéus-Conquista, bem como na formação da lavoura do cacau, no sul da Bahia oitocentista.

\subsection{Os delineamentos da política indigenista colonial e imperial voltados a atender as de- mandas de trabalho dos índios aldeados}

A política indigenista do início do século XIX é marcada, segundo Carneiro da Cunha, por um hiato legislativo, tendo em vista a extinção do Diretório Pombalino, em 1798, e a vigência de outro conjunto de normas legislativas para os índios do Império, a partir de $1845^{1}$. Ressalta-se, contudo, que a ideia de um hiato legal observado por Manuela Carneiro da Cunha na governança dos índios após o Diretório Pombalino tem sido repensada, mais recentemente, pela reflexão de historiadores como Patrícia Melo Sampaio, para quem a existência de uma lacuna legal, como assevera Cunha acerca do contexto indigenista posterior à extinção do Diretório Pombalino, poderia ser

1 CUNHA, Manuela Carneiro da. Política Indigenista no século XIX. In: CUNHA, Manuela Carneiro da (Org.). História dos índios no Brasil. São Paulo: FAPESP, Companhia das Letras, 1992, p. 138. 
considerada, no sentido de que a Carta Régia, de 1798, não tenha se tornado uma nova política indigenista geral ${ }^{2}$. Essa assertiva não inviabiliza, contudo, o entendimento do seu direcionamento político e administrativo para analisar a questão indígena sob uma nova conjuntura, acentuada progressivamente no problema da ocupação territorial, como asseverou a própria Manuela Carneiro da Cunha.

No que refere à incorporação dos índios como mão de obra, Sampaio observou a especificidade da Carta de 1798 para a Amazônia. No que diz respeito à ênfase dada "à questão da disponibilidade de trabalhadores", a Carta recomendou, nos anos subsequentes ao Diretório pombalino, a "individuação dos índios aldeados", por um lado; por outro, a tutela "regulada pelos Termos de Educação" aos índios não aldeados ${ }^{3}$. Nesse escopo analítico, a autora frisa que faltam estudos locais que deem conta da circunstância histórica específica em que surgiu a Carta de 1798 "[p] roduzida em uma conjuntura de mudanças políticas no ultramar e na própria colônia"4. Sampaio ressalta ainda: "uma análise da natureza e dos efeitos da Carta de 1798 pode colaborar não só na ampliação das discussões quanto à política indigenista brasileira, mas também ampliar nossa compreensão de uma região e de suas muitas especificidades" ${ }^{\prime \prime}$.

Em outro estudo, Sampaio frisa que embora não houvesse, na virada do século, um corpo documental unificado e geral que legislasse sobre as populações indígenas,

2 SAMPAIO, Patrícia Maria Melo. Espelhos partidos: etnia, legislação e desigualdade na Colônia. Manaus: Editora da Universidade Federal do Amazonas, 2011, p. 245.

3 Idem, p. 246.

4 Idem, ibidem.

5 Idem, ibidem. 
não procede a máxima historiográfica de "vácuo legal" para os primeiros anos do século XIX'. A argumentação de Sampaio apoia-se na observação da administração dos índios do Grão Pará e Maranhão durante aquele período, marcada por determinações régias, provisões, decretos, entre outras medidas legais específicas para aquela região ${ }^{7}$.

O Diretório de 1758 previa a política indigenista como estágio necessário à civilização dos índios. Para tanto, Pombal propôs mudanças decisivas para alcançar tal objetivo; em consequência disso, o Diretório pombalino instalou uma administração secular para os índios, que culminaria na expulsão dos jesuítas da Colônia. Como bem destaca Carneiro da Cunha, a partir dessa medida, o que se pode notar, em início do século XIX, com a chegada da família real ao Brasil, será o encurtamento das distâncias que separavam os interesses e as ideologias do poder central e do poder local, já que, sem a voz dissonante dos jesuítas, os interesses centrais da monarquia portuguesa e locais, dos colonos, acerca do governo dos índios, convergem e se entrelaçam mais facilmente, inclusive porque houve um encurtamento das distâncias físicas entre ambos ${ }^{8}$.

Para Sampaio, ao contrário de um hiato legislativo para as questões indígenas após a abolição do Diretório, o que se nota é a profusão de políticas alternativas que atendiam diretamente às demandas regionais. Ainda salienta que, naquele momento, isto é, nas primeiras décadas do século XIX, não existia unidade administrativa para a Colônia, de um modo geral. Portanto, as medidas indigenistas adotadas estavam voltadas para atender os interesses locais.

6 SAMPAIO, Patrícia Melo. Op., cit., 2009, p. 184.

7 Idem, ibidem

8 Idem, p.133 
Dentre os direcionamentos principais com relação à questão indígena, sob a égide do Diretório de 1758, destacam-se dois elementos: mão de obra e ocupação territorial, dois temas correlacionados. $\mathrm{O}$ incentivo de não índios em aldeamentos e vilas de índios visava promover a mistura biológica e cultural, que significava uma nova forma de incorporar o índio no projeto de colonização e obter mão de obra para os serviços públicos e particulares. Nesse sentido, o trabalho indígena, que já era utilizado antes do Diretório, continua sendo um tema central tratado pela legislação. Sobre o caráter de continuidade do interesse pelo trabalho indígena após a extinção do Diretório Pombalino, Fátima Lopes observa que, embora a Rainha declarasse tratamento igual para todos os seus vassalos, incluindo os índios, na prática as diferenças eram mantidas. Os índios continuavam atuando em serviços obrigatórios, como o militar, e como canoeiros. Permanecia em prática, portanto, "o controle sobre o que identificava como a 'natural ociosidade [dos indígenas] a que os convida o clima', através do trabalho [...], que deveria ser coordenado pela junta da Fazenda e pelo Ouvidor" ${ }^{\prime \prime}$. Ou seja, o controle sobre o trabalho dos índios continuou a ser objeto de grande interesse da Coroa, que prescrevia, inclusive, o uso da "força" para obtê-lo ${ }^{10}$.

O decreto de 1798, que abolia o Diretório Pombalino e dava outras providências, reafirmava o princípio de integração do índio ao projeto colonial com vistas a atender, principalmente, a demanda de mão de obra. Nas palavras de Moreira Neto, as instruções do novo corpo legal dirigiam-se "a objetivos mais concretos, dispondo sobre a

9 LOPES, Fátima Martins. Em nome da liberdade: As vilas de índios do Rio Grande do Norte sob o Diretório Pombalino no século XVIII. Tese de doutorado. Universidade Federal de Pernambuco. Recife, 2005, p. 395.

10 Idem, Ibidem. 
organização dos índios em corpos de trabalho."11 A nova orientação legal confirmava, mais uma vez, o interesse lusitano na utilização da mão de obra indígena. Nesse escopo, Vânia Moreira confirma, em seus estudos sobre o Espírito Santo de fins do Setecentos, a prática do uso do trabalho compulsório dos índios. Em Nova Benavente, eles eram empregados compulsoriamente em serviços públicos e em fazendas de particulares. Isso fica em evidência quando das queixas dos índios à Rainha, com relação ao que eles entendiam como abuso da exploração da sua mão de obra, pois, como lembravam a d. Maria I, eles nasceram "livres do ônus de cativeiro." 12

A orientação legal de organização dos índios em corpos de trabalho continua durante o período imperial no Brasil. Segundo Claudia Fuller, na Província do Pará, os corpos de trabalhadores se constituíam através do recrutamento de índios, mestiços, e pretos para os serviços públicos e particulares. Nas palavras da autora, "se a ociosidade [dos índios] podia ser explicada [pela abundância natural do território], ela não poderia ser justificada nem mantida, cabendo o papel de coibi-la aos órgãos administrativos." ${ }^{13}$ Corroboramos, portanto, a ideia de que, durante o Oitocentos, o interesse pelo trabalho das populações indígenas aldeadas continuou a ser uma preocupação administrativa no Brasil.

Na apresentação de Negros da Terra, John Monteiro faz algumas ponderações importantes a respeito da pouca importância dedicada ao trabalho indígena nos estudos sobre

11 Idem, ibidem.

12 MOREIRA, Vânia Maria Losada. Op., cit., 2013, p.263.

13 FULLER, Claudia Maria. “Os corpos de trabalhadores e a organização do trabalho livre na província do Pará (1838-1859)". Mundos do trabalho. Florianópolis: GT Mundos do Trabalho/Associação Nacional de História, v. 3, n. 6, 2011, p. 57. 
a sociedade colonial, cuja reflexão contribui para o agenciamento de estudos dedicados a pensar a questão do trabalho no século XIX. Pela negligência ou pouca atenção da historiografia, a exploração do trabalho dos índios no período colonial, por muito tempo, ocupou apenas o lugar de mão de obra de transição para o trabalho escravo africano, o que os colocava à margem da história do trabalho no Brasil colonial. Como bem observa Monteiro, "as principais tendências do estudo da Colônia permanecem subordinadas a um quadro teórico no qual a organização do trabalho se atém à lógica da expansão do capitalismo comercial."14

A historiografia do trabalho tem produzido algumas reflexões acerca da ideia de uma transição da modalidade do trabalho escravo para o trabalho assalariado, há muito engendradas pelos estudiosos da área. Realmente, a perspectiva agenciada pelas novas reflexões acerca do trabalho no Oitocentos permite pensar o trabalho, não somente o trabalho, por outros vieses interpretativos, como também colocar em cena outros atores sociais. Este capítulo se aproxima das ideias gestadas em alguns estudos envolvidos na tarefa de pensar esses outros vieses de interpretação para o trabalho, no século XIX.

Nesses termos, a permanência da exploração sistemática do trabalho indígena em moldes compulsórios, nos anos imperiais, permite observar os delineamentos da organização do trabalho livre e assalariado no Brasil, ao lado de outras formas de trabalho, como o não assalariado e o escravo. Beatriz Mamigonian e Fabiane Popinigis ressaltam que, "[na] verdade, inúmeras formas de trabalho compulsório ou não remunerado coexistiam com a

14 MONTEIRO, John Manuel. Negros da Terra: índios e bandeirantes nas origens de São Paulo. São Paulo: Companhia da Letras, 1994, p. 8. 
escravidão e se expandiam depois da abolição"15. Como Mamigonian observou, o recrutamento de africanos recém resgatados do tráfico e o recrudescimento da repressão ao tráfico de escravos, por parte do governo britânico, eram elementos estrategicamente correlacionados. A autora salienta que, a partir da década de 1840, são intensificadas as práticas de recrutamento de africanos recém-resgatados, bem como de africanos livres no Brasil. Esses africanos recrutados seriam uma das principais fontes de mão de obra direcionada para as colônias britânicas. Nas palavras da autora: "O maior fluxo de trabalhadores por contrato para as colônias britânicas nos anos seguintes à abolição da escravidão veio diretamente dos navios negreiros julgados por tribunais britânicos"16.

Nosso estudo sobre a exploração do trabalho dos índios de Ferradas em situação de territorialização se aproxima das ideias de Fátima Lopes, Moreira Neto e Vânia Moreira acerca do trabalho compulsório dos índios aldeados. Além disso, comunga com as ideias gestadas pela historiografia do trabalho, a exemplo de Claudia Fuller, Beatriz Mamigonian e Fabiane Popinigis, aqui expostas. Os estudos explicitados permitem vislumbrar e problematizar, ainda que não de forma conclusiva, uma realidade de trabalho compulsório remunerado, parcialmente remunerado ou não remunerado dos aldeados de Ferradas nos serviços públicos e em serviços particulares naquela parte do sul da Bahia.

15 MAMIGONIAN, Beatriz G.; POPINIGIS, Fabiane. Dossiê (Outros) Trabalhadores livres no Atlântico oitocentista. Mundos do trabalho. Florianópolis: GT Mundos do Trabalho/ Associação Nacional de História, v. 3, n. 6, 2011, p. 4.

16 MAMIGONIAN, Beatriz G. “Em nome da liberdade: abolição do tráfico de escravos, o direito e o ramo brasileiro do recrutamento de africanos (Brasil-Caribe britânico, 1830-1850)". Mundos do trabalho. Florianópolis: GT Mundos do Trabalho/ Associação Nacional de História, v. 3, n. 6, 2011 p. 74. 
Sendo assim, entendemos que garantir a existência dos aldeamentos era, para a política colonial, um meio de garantir o acesso da Coroa e dos colonos à mão de obra indígena. Esse objetivo e interesse primordial estão presentes nos aldeamentos implantados em início do XIX, e se estenderá até a política indigenista de 1845, quando, em termos legais, o interesse pela mão de obra indígena diminui e o foco se desloca para a apropriação das terras dos índios. É nesse contexto que se instala, em 1814, o aldeamento São Pedro de Alcântara na comarca de Ilhéus, no sul da Província da Bahia. E podemos caracterizá-lo como um "aldeamento tardio", termo cunhado por Celestino de Almeida ${ }^{17}$.

Os aldeamentos tardios, segundo Almeida, foram aqueles espaços de catequese indígena implantados em fins do setecentos e início do oitocentos, e embora tivessem sua fundação delimitada ainda no período colonial, mantinham características díspares dos aldeamentos jesuíticos "quanto à integração dos índios e suas relações com os colonizadores"18. Ressalta a autora que, no final do século XVIII e início do XIX, a sua função girava em torno da pacificação de territórios para fins de estabelecimento de fazendeiros e para "possibilitar aos moradores o trabalho dos índios em seus pastos e lavouras, bem como nos cortes de madeira, serviço no qual os índios das aldeias do atual norte fluminense foram amplamente empregados"19. Contudo, esses aldeamentos, fundados tardiamente na Colônia, traziam em si outros objetivos concretos, que delineavam as políticas adotadas para os índios nos

17 ALMEIDA, Maria Regina Celestino de. Metamorfoses indígenas: Identidade e cultura nas aldeias do Rio de Janeiro. 2. ed. Rio de Janeiro: Editora FGV, 2013, p. 102.

18 Idem, ibidem

19 Idem, p. 241. 
anos finais da Colônia e que seriam recrudescidos durante todo o período imperial, tais como a estratégia da mistura. Embora não constatemos a mistura efetiva dentro do aldeamento de índios e não índios, através do trabalho dos indígenas uma fronteira social muito fluida era mantida entre os aldeados de Ferradas e os colonos e viajantes, entre outros atores no sul da Bahia, durante o século XIX.

Nessa perspectiva, definimos o Aldeamento São Pedro de Alcântara como um aldeamento tardio. Fundado no final do período colonial, o aldeamento cumpriu a função de pacificar o território a ser ocupado pela política de colonização e foi fundamental para o êxito de tal projeto. Também funcionou como reserva constante de mão de obra para os serviços públicos e particulares na região sul da Bahia. Convém ressaltar que o trabalho dos aldeados de Ferradas foi expressivo, na região, por todo o período de vigência do aldeamento, como sobejamente atesta a documentação primária que existe sobre ele.

\subsection{Expansão territorial e trabalho: a construção da lavoura dos "frutos de ouro", no sul da Bahia oitocentista}

Abaixo, segue o quadro do movimento de compra e venda de terras na região, que compreende a área de Cachoeira de Itabuna e suas proximidades e que nos possibilita perceber o processo de colonização e valorização da localidade. Vale ressaltar que o movimento de ocupação territorial configurou o sul da Bahia como "região cacaueira", e isso muito se deve à atuação dos indígenas aldeados, sujeitos ativos naquele processo histórico. 
Dentre os 10 livros consultados, que compreendem a primeira e segunda metade do século XIX, 1814 a 1876, foram selecionadas as escrituras que mencionam a região do estudo em foco ${ }^{20}$.

\section{TABELA 2 - Escrituras de compra e venda de terras em Cachoeira de Itabuna, século XIX}

\begin{tabular}{|c|c|c|}
\hline ANO & $\mathrm{N}^{\circ}$ DE ESCRITURAS & $\begin{array}{c}\text { SITUAÇÃO DE } \\
\text { CULTIVO DA TERRA }\end{array}$ \\
\hline 1814 & 1 escritura & Sorte de terras \\
\hline 1822 & 1 escritura & Sorte de terras \\
\hline 1824 & 1 escritura & Sorte de terras \\
\hline 1846 & 1 escritura & Pedaço de terras \\
\hline 1849 & 1 escritura & Pedaço de terras \\
\hline 1850 & 2 escrituras & $\begin{array}{l}\text { Pedaço de terras } \\
\text { Fazenda com plantação } \\
\text { diversa }\end{array}$ \\
\hline 1851 & 3 escrituras & $\begin{array}{l}\text { Fazenda de cacau } \\
\text { Uma fazenda } \\
\text { Fazenda de cacau }\end{array}$ \\
\hline 1853 & 1 escritura & $\begin{array}{l}\text { Fazenda com escravos e } \\
\text { benfeitorias (cacau e café) }\end{array}$ \\
\hline 1854 & 1 escritura & Pedaço de terras \\
\hline 1855 & 1 escritura & Sorte de terras \\
\hline 1856 & 2 escrituras & $\begin{array}{l}\text { Fazenda de cacau } \\
\text { Fazenda de cacau }\end{array}$ \\
\hline 1858 & 2 escrituras & $\begin{array}{l}\text { Uma fazenda } \\
\text { Venda de pés de cacau } \\
\text { e café }\end{array}$ \\
\hline 1859 & 1 escritura & Plantação de cacau \\
\hline
\end{tabular}

(Continua)

20 Muito embora os profissionais do Arquivo Público do Estado da Bahia se empenhem num trabalho criterioso, comprometido e responsável com o tratamento e conservação das fontes sob a custódia da instituição, os livros de notas da vila de Ilhéus estão, em sua maioria, em péssimo estado. Isso dificultou o nosso trabalho de pesquisa e, por isso, o demonstrativo das escrituras para a região da Cachoeira de Itabuna se limita ao conjunto dos livros possíveis de consulta. 
(Conclusão)

\begin{tabular}{|l|l|l|}
\hline \multicolumn{1}{|c|}{ ANO } & \multicolumn{1}{|c|}{$\mathbf{N}^{\mathbf{0}}$ DE ESCRITURAS } & \multicolumn{1}{|c|}{$\begin{array}{c}\text { SITUAÇÃO DE } \\
\text { CULTIVO DA TERRA }\end{array}$} \\
\hline 1870 & 1 escritura & Fazenda de cacau \\
\hline 1872 & 1 escritura & Uma fazenda de cacau \\
\hline 1873 & 4 escrituras & $\begin{array}{l}\text { Uma fazenda de cacau } \\
\text { Pedaço de terras } \\
\text { Uma fazenda de cacau } \\
\text { Uma fazenda com } \\
\text { plantação de cacau }\end{array}$ \\
\hline 1875 & 1 escritura & $\begin{array}{l}\text { Uma fazenda com } \\
\text { plantação de cacau }\end{array}$ \\
\hline 1876 & 4 escrituras & $\begin{array}{l}\text { Uma fazenda com } \\
\text { plantação de cacau } \\
\text { Uma plantação de cacau } \\
\text { Uma plantação de cacau } \\
\text { Um pedaço de terra }\end{array}$ \\
\hline
\end{tabular}

Fonte: Tabela construída a partir dos livros de notas da Vila de Ilhéus - Arquivo Público do Estado da Bahia. Livros: 5 e 6; 11 a 16; 20 e 21.

O demonstrativo das escrituras é irrisório do ponto de vista quantitativo. No entanto, se fizermos uma análise com base no contexto da Lei de Terras de 1850 e seus desdobramentos para aquela parte do sul da Bahia oitocentista, podemos perceber uma configuração interessante dentro do processo de construção da lavoura do cacau. Tendo como base os estudos de Lígia Osório e Márcia Motta acerca da Lei de Terras de 1850 e seus desdobramentos, com especial atenção para a continuidade da prática do apossamento de terras mantida no Brasil mesmo após a promulgação da referida lei, e levando-se em conta que tal prática interessava principalmente aos grandes fazendeiros, é possível afirmar que o número de escrituras não representa, necessariamente, o nível de ocupação real da 
região ${ }^{21}$. Em outras palavras, a pequena quantidade de escrituras para Cachoeira de Itabuna não significa pouca ocupação real daquela região, pois a prática de continuar o apossamento (ilegal, a partir de 1850) de terras pode também ter ocorrido naquela parte do sul da Bahia, visto que estamos falando de uma zona que se conformará, ao longo do século XIX, como região cacaueira, e daí a configuração de pequenas e médias propriedades, mas também grandes fazendas e latifúndios de cacau ${ }^{22}$.

Pelo movimento de compra e venda de terras analisado, os produtores do sul da Bahia não estavam interessados em comprar terras. Pelo contrário, na região da incipiente lavoura do cacau parecia mais interessante alargar antigas posses ou fazer novas, em vez de comprar terras do governo. Como demonstrou Osório, o apossamento de terras devolutas era uma prática permanente em todo o Brasil durante o Oitocentos. Apesar de o governo imperial definir a prática da posse oficialmente como prática ilegal,

(...) a resistência de setores importantes da sociedade (as classes dominantes no campo, em especial) apoiadas numa parcela cada vez mais expressiva dos juristas,

21 Sobre a Lei de Terras de 1850 e a permanência da prática da posse da terra após a promulgação da referida lei, ver: SILVA, Lígia Osório. Terras devolutas e latifúndios: efeito da Lei de 1850. Campinas: Editora da UNICAMP, 1996.

22 Os estudos mais atuais sobre a região sul da Bahia que detenham atenção sobre questões relacionadas à lavoura do cacau, têm como principal referência a tese de doutoramento de MAHONY, Mary Ann. The World Cacao Made: Society, Politics and History, in Southern Bahia, Brazil, 18221919. Dissertation of the degree of doctor of Philosophy. Yale University. Estados Unidos, 1996. Bem como estudos relacionados: "Instrumentos necessários" escravidão e posse de escravos no sul da Bahia no século XIX, 1822-1889. Afro-Ásia. Salvador: Centro de Estudos Afro-Orientais. Universidade Federal da Bahia, n. 25-26, 2001, p. 95-139. 
obrigou algumas concessões. Mais importante do que essas concessões, que foram sendo feitas numa tentativa de salvaguardar a autoridade governamental, constantemente desafiada nesse campo, foi a paulatina disseminação da convicção de que era legalmente impossível e socialmente indesejável a completa sustação da posse como meio de aquisição das terras devolutas ${ }^{23}$.

Para Márcia Motta, um dos problemas a ser enfrentado pela Coroa portuguesa no Brasil colonial, com a implantação de um sistema jurídico para resolver a questão da terra, era o problema da colonização, associado diretamente à permanência e ao fortalecimento da figura do posseiro. Problema complexo, que perdurará durante os anos posteriores à promulgação da Lei de Terras de $1850^{24}$. Nesta lei, a figura do posseiro continua central. Para Motta, a ambiguidade da lei consistia justamente aí, na incapacidade de superar a história de ocupação territorial e trazer o princípio da ocupação, do cultivo ${ }^{25}$.

Ainda segundo Motta, "a maior parte dos posseiros era constituída por, de fato, grandes fazendeiros - muitos deles com prestígio e poder em sua localidade" ${ }^{26}$. A lei de 1850, ao relaxar as diretrizes quanto à posse e regulamentação da terra, reconhecendo nela a legitimidade das posses, abria uma janela para o processo de concentração fundiária, inclusive ilegal. O sistema de apossamento irá perpassar a discussão em torno da questão fundiária, no Brasil, por todo o Oitocentos. No relatório do Ministério

23 SILVA, Lígia Osório. Op., cit., p. 153.

24 MOTTA, Márcia Menendes. Nas fronteiras do poder: conflito e direito à terra no Brasil do século XIX. 2. ed. Rio de Janeiro: EDUFF, 2008, p. 130-131.

25 MOTTA, Marcia Menendes. Op., cit., p. 57.

26 Idem, p. 155. 
da Agricultura, de 1870, era proposta a revisão da Lei de 1850, "de modo a estabelecer disposições em favor dos posseiros posteriores ao regulamento de $1854^{\prime 27}$.

Desse modo, no contexto do sul da Bahia, em meados do século XIX, não se deve tomar como testemunho de ocupação territorial o quantitativo de escrituras existentes, pois as posses poderiam conviver lado a lado com as terras efetivamente escrituradas. Mas a crescente existência de escrituras na região é um sinal da valorização comercial dessas terras, e demonstra a preocupação de certos indivíduos em resguardar seus direitos por meio de títulos de propriedade. Afinal, o cacau do sul da Bahia foi produzido em latifúndios e esses "latifundiários e fazendeiros de cacau estavam entre os mais importantes políticos e burocratas na Ilhéus do fim do século XIX e início do século XX", como lembrou Mary Mahony ${ }^{28}$.

Como podemos observar no quadro acima, a partir de 1850 não aparece mais a terminologia terras nas escrituras de compra e venda, pois embora em pequena quantidade, o que se começa a negociar são plantações ou fazendas de cacau. Isso significa que o cultivo do cacau estava se consolidando naquela parte do sul da Bahia. Para tanto, dentre outros atores sociais, os indígenas aldeados exerceram papel fundamental, não apenas como pacificadores do território, mas também como trabalhadores ativos na implantação da lavoura cacaueira, pois cultivar cacau era uma das atribuições dos indígenas de São Pedro de Alcântara, como explicitado anteriormente. Trataremos melhor acerca do trabalho indígena na lavoura do cacau ao final deste capítulo.

27 Idem, p. 171.

28 MAHONY,Mary Ann. "Instrumentos necessários" escravidão e posse de escravos no sul da Bahia no século XIX, 1822-1889. Afro-Ásia, n. 25-26. Universidade Federal da Bahia. 2001, p. 137. 
Definir Cachoeira de Itabuna como região crescentemente cacaueira é pensá-la como zona de fronteiras fluidas ${ }^{29}$, onde se encontravam índios, escravos, autoridades governamentais, grandes fazendeiros e pequenos colonos. Portanto, é importante reconhecer a presença indígena no processo inicial de formação das roças de cacau ao lado da presença e da atuação escrava na incipiente lavoura cacaueira.

Em suas pesquisas e investigações sobre o sul da Bahia oitocentista, Mary Ann Mahony desconstrói uma escrita regional que mitificou a implantação da lavoura do cacau como empreendimento que não teria feito uso da mão de obra escrava de origem africana ou afrodescendente, supostamente apenas utilizada nos engenhos de açúcar da Ilhéus colonial. No entanto, a partir de cuidadoso trabalho com as fontes, Mahony sustenta a tese da presença escrava na lavoura do cacau, afirmando que essa presença não só teria desempenhado papel fundamental para a economia regional, como também para a configuração social e política que se estabeleceria na região ${ }^{30}$.

No artigo intitulado "Instrumentos necessários" escravidão e posse de escravos no sul da Bahia no século XIX, 18221889, a autora apresenta algumas informações pertinentes para entendermos a "escravidão na ascensão do cacau" no sul da Bahia oitocentista. Mahony reconhece que a presença escrava em Ilhéus foi inexpressiva em termos de quan-

29 Nesse processo, é bastante pertinente a definição de fronteira de MUÑOZ, Laura. Bajo el cielo ardiente de los trópicos: Las fronteras del Caribe em el siglo XIX. In: GUTIÉRREZ, Horacio; NAXARA, Márcia R. C. e LOPES, Maria Aparecida de S. (Orgs.). Fronteiras: paisagens, personagens, identidades. Franca: UNESP, S. Paulo: Olho D’Água, 2003, p. 56: “La frontera se manifesta más como área de contacto, de encuentros y entrecruzamientos. Desde puestos de observación móviles, flotantes a veces, esas miradas perciben la imagen de una frontera viva, mutable, porosa, una zona de interacción".

30 MAHONY, Mary Ann. Op., cit., 2001, p. 137-138. 
tidade, se comparada a outras regiões do país. No entanto, frisa que tal assertiva não significa a ausência da mão de obra escrava na ascendente lavoura. Mary Mahony observa que na lavoura do cacau, diferentemente de outras culturas, como o café no Vale do Paraíba ou oeste paulista ${ }^{31} \mathrm{e}$ o mercado do açúcar na Bahia, não havia necessidade de grande investimento de capital e de um contingente numeroso de mão de obra ${ }^{32}$. Dessa forma, não era necessário um grande número de escravos.

Embora a proeminência agrícola estivesse voltada para o açúcar na Bahia colonial, em fins do século XVIII e início do século XIX os olhares começam a voltar-se para a cultura do cacau. Mahony ressalta que, na década de 1780, as autoridades governamentais já incentivavam o plantio do cacau na região ${ }^{33}$. No entanto, o cultivo se desenvolveu lentamente, visto que os investidores da região "estavam mais interessados em madeira, açúcar e mandioca" 34 . Contudo, Mahony destaca o interesse dos imigrantes alemães e suíços com relação à lavoura do cacau na região, a partir da abertura dos portos. Realça que, na década de 1830, o sul da Bahia já exportava anualmente 26 toneladas de ca$\mathrm{cau}^{35}$. Nas décadas posteriores, a lavoura do cacau cresceu de forma acelerada nessa região. Nas palavras de Mary Mahony, "em 1888, já haviam sido plantados cacaueiros em quantidade suficiente para permitir que o sul da Bahia exportasse 13.000 toneladas de cacau em 1900 e se tornasse um dos principais produtores mundiais". ${ }^{36}$

31 Idem, p. 96.

32 Idem, p. 105-106.

33 Idem, ibidem

34 MAHONY, Mary Ann. Op., cit., p.105-106.

35 Ibidem.

36 Idem, p. 107. 
Segundo Mahony, na década de 1880, as maiores plantações de cacau do sul da Bahia pertenciam às famílias mais ricas, que cultivavam em suas instalações em torno de 100.000 pés de cacau, além de obter engenhos de açúcar e cafezais. Já as instalações intermediárias cultivavam em torno de 5.000 a 10.000 pés de cacau e a maior parte se constituía de pequenas propriedades que ficavam à margem da produção, com cerca de 1.000 pés de cacau. ${ }^{37}$

Para Mahony, a "discussão acerca de escravos e de escravidão em Ilhéus tem demonstrado que os escravos e a escravidão foram importantes para a cidade no século XIX e para o início da cultura do cacau" ${ }^{38}$. Na mesma direção, observamos que a política de aldeamentos de catequese e a atuação dos índios aldeados foram determinantes para o processo de formação e consolidação da lavoura em grande parte do território do sul da Bahia, tendo em vista que o aldeamento de Ferradas existiu na região por grande parte do século XIX. Não se tem notícias sobre o aldeamento após 1861, pois a documentação existente, posterior a esse momento, refere-se ao aldeamento como estabelecimento supostamente extinto. Exemplo disso é a menção a Ferradas como "antiga aldeia" em correspondência do juiz Antônio Villaça, em 1868, quando o mesmo informou à presidência da província sobre o estado da estrada IlhéusConquista, ele mencionou que a estrada à margem do Rio Cachoeira até a antiga aldeia de Ferradas oferecia muitas dificuldades ${ }^{39}$.

A relevância e a funcionalidade dos aldeamentos no sul da Bahia são confirmadas indiretamente pela exposição

37 Idem, p. 108.

38 Idem, p. 137.

39 APEB. Seção Arquivo Colonial e Provincial, série Justiça - juízes de Ilhéus, maço 2401, fl. 8, ano 1868. 
de Silva Campos, para quem a entrada de migrantes na região começou e priorizou principalmente "a parte mais cultivada do município de Ilhéus, que eram as margens do rio Cachoeira, localizando-se até à aldeia de Ferradas"..$^{40}$

\subsection{O trabalho dos aldeados de Ferradas nos serviços pú- blicos e particulares}

No projeto imperial destinado à região, o interesse mais visível que aparece na documentação é em relação ao trabalho indígena. Nesse sentido, o sul da Bahia se assemelhava ao Espírito Santo, pesquisado por Vânia Moreira. A autora enfrenta a produção historiográfica de invisilibização dos índios no processo de colonização brasileiro, e coloca-os no centro do debate sobre a organização social do trabalho no Espírito Santo, na primeira metade do século XIX, tendo como objeto de estudo a participação dos índios de Nova Almeida no mundo do trabalho e seus desdobramentos para a conformação social daquela região ${ }^{41}$. Da mesma forma, no sul da Bahia, ao longo do século XIX, também era indisfarçável o interesse das autoridades pela mão de obra dos indígenas. Nesta realidade, o assunto trabalho norteou as práticas administrativas por todo o período de vigência do aldeamento São Pedro de Alcântara.

O século XIX é um período politicamente heterogêneo, como bem frisa Manuela Carneiro da Cunha ${ }^{42}$. Igualmente heterogêneas foram as leis ou regras instituídas

40 CAMPOS, João da Silva. Op., cit., p. 391.

41 MOREIRA, Vânia Losada. "A serviço do império e da nação: trabalho indígena e fronteiras étnicas no Espírito Santo (1822-1860)". Anos 90, Porto Alegre, v. 17, n. 31. 2010a, p. 14-15.

42 CUNHA, Manuela Carneiro da. Op., cit., p. 133. 
para o governo das populações indígenas do Brasil. Sampaio frisa que a novidade emergida da legislação indigenista de 1845 foi a "regulamentação da possibilidade de arrendamento e aforamento de terras indígenas" ${ }^{43}$. Esse aspecto do Decreto 426 ocasionou querelas parlamentares e opiniões desfavoráveis. Segundo Kodama, Carneiro Leão, que era membro da Comissão de Estatística, Catequese e Colonização do Senado, ressaltava o caráter negativo do arrendamento das terras indígenas, explicitando os abusos que decorreriam de tal diretriz sobre as terras que pertenciam a essas populações. De fato, a pesquisa de Manuela Carneiro da Cunha corroborou a opinião de Carneiro Leão, pois ela observa que um dos principais efeitos da regulamentação de 1845 foram as expropriações das terras indígenas, processo decorrente da política de disseminação de aldeamentos com a mistura de índios e não índios, tendo como propósito a rápida emancipação dos índios e extinção de seus territórios. ${ }^{44}$

Manuela Carneiro da Cunha pontua como caráter central na legislação indigenista, que emergiria dos debates políticos dos meados do Oitocentos, a questão do acesso e posse da terra. Para a autora, o interesse pelo trabalho indígena continuaria presente nas medidas políticas com relação ao governo dos índios, mas de forma secundária e transitória ${ }^{45}$. Porém, como ainda sugere a própria autora, “a política de terras não é, portanto, a rigor, independente de uma política de trabalho" ${ }^{46}$. Por conseguinte, diferentemente do que afirmou Cunha a respeito da transitoriedade do trabalho indígena, observamos que, no sul da Bahia,

43 SAMPAIO, Patrícia Melo. Op., cit., 2009, p. 186.

44 KODAMA, Kaori. Op., cit., p. 257.

45 CUNHA, Manuela Carneiro da. Op., cit., p. 133.

46 Idem, p. 141. 
durante todo o século XIX, o interesse pela mão de obra dos homens e mulheres em "situação de aldeamento" fica em evidência na documentação compulsada.

Nessa perspectiva, a partir de 1845, escreve Patrícia Sampaio: "é imperioso recuperar a permanência da questão relativa ao acesso ao trabalho indígena, que ainda era extremamente relevante, mesmo naqueles lugares em que o esforço de tomar de assalto as terras das aldeias se fez mais efetivo" ${ }^{47}$ Nessa direção, nosso objetivo, neste estudo, é demonstrar que, na região de Cachoeira de Itabuna, sul da Bahia, na prática, a questão do trabalho indígena foi uma preocupação central até pelo menos o final da década de 1850, como nos permite observar a documentação.

Também as pesquisas de Vânia Moreira insistem na importância do trabalho indígena em certas regiões do Império. Referindo-se à Província do Espírito Santo, a autora observa "que é o sistema governativo para gerir o trabalho dos índios que entra em colapso a partir da década de 1840, não o costume de os índios prestarem serviços ao Estado e aos particulares" ${ }^{\prime 4}$. Moreira estabelece, como hipótese de estudo, que foi frequente a utilização da mão de obra indígena na região da Vila de Nova Almeida, na primeira metade do século XIX, e que os índios foram importantes "na organização e no funcionamento do mundo do trabalho na região". ${ }^{49}$

No seu estudo sobre a província do Espírito Santo, Moreira concorda com o fato de que na provincia tinha havido predominancia da população indígena. No entanto, diferentemente da visão mais aceita e veiculada pela historiografia acerca da província, ela lembra que, além das tribos hostis,

47 SAMPAIO, Patrícia Melo. Op., cit., 2009, p. 188.

48 MOREIRA, Vânia Losada. Op., cit., 2010a, p. 28.

49 Idem, p. 15. 
que viviam nos sertões, existiam os índios que moravam nas vilas, demonstrando a participação efetiva deles na vida política e social. A perspectiva teórica e metodológica proposta por Moreira se faz fundamental para pensarmos o estudo em andamento. Desse modo, tentaremos demonstrar a atuação dos indígenas aldeados em Ferradas, sul da Bahia, como atores no processo de construção e desenvolvimento de Cachoeira de Itabuna.

Dentre outras fontes, nossa pesquisa se apoia em escrituras de compra e venda de terras, relatórios presidenciais e cartas, nas correspondências trocadas entre autoridades de Ilhéus e a presidência da Província da Bahia. No total das correspondências relacionadas ao aldeamento, selecionamos aquelas nas quais aparece o tema trabalho; e, dentre essas, apenas aquelas em que fica claro o tipo de trabalho desenvolvido pelos indígenas aldeados de São Pedro de Alcântara (tabela 3).

TABELA 3 - Tipos de trabalho desenvolvido pelos índios aldeados, 1830-1850

\begin{tabular}{|l|l|}
\hline Décadas de $\mathbf{1 8 3 0}$ e $\mathbf{1 8 4 0}$ & Quantidade de ocorrências \\
\hline Agricultura & 4 \\
\hline Corte de madeira & 1 \\
\hline Fabricação de canoas & 2 \\
\hline Abertura e conservação da estrada & 2 \\
\hline Navegação & 1 \\
\hline Década de 1850 & Quantidade de ocorrências \\
\hline Agricultura & 4 \\
\hline Fabricação de canoas & 1 \\
\hline Navegação & 1 \\
\hline Abertura e conservação da estrada & 4 \\
\hline Total & 20 \\
\hline
\end{tabular}

Fonte: Tabela construída a partir das correspondências das autoridades provinciais, seção Arquivo Colonial e Provincial, maços: 2396, 4612 e 4613. Arquivo Público do Estado da Bahia. 
No conjunto das correspondências analisadas, observamos que o interesse pelo trabalho indígena continua central para o bom êxito do projeto imperial, tendo em vista a manutenção do Aldeamento de Ferradas até a segunda metade do século XIX e a instalação de outros aldeamentos nos mesmos moldes em outras partes da região sul da Bahia. Durante o século XIX, houve um premente interesse pelo acesso à terra no sul da Bahia, pois se tratava de uma região que se consolidaria no final daquele século enquanto "região cacaueira", se estabelecendo ali os latifúndios da lavoura do cacau.

Numa análise das correspondências oficiais das autoridades locais às autoridades provinciais, incluindo requerimentos, ofícios, dentre outras, percebemos que São Pedro de Alcântara se configurava como uma espécie de celeiro de mão de obra para os trabalhos públicos naquela área, com especial atenção para as obras destinadas a alargar, aumentar o percurso e manter em funcionamento a estrada que ligava a Vila de Ilhéus à de Vitória. Manter a estrada limpa e transitável era garantir o acesso das pessoas e, sobretudo, viabilizar o comércio entre as referidas vilas, além de assegurar, nas áreas próximas à estrada, o assento e a permanência de colonos.

Em documento de 30 de junho de 1843, do juiz municipal de Órfãos e delegado das vilas de Rio de Contas, Olivença e Ilhéus, Joaquim José Pinheiro de Vasconcelos, anexo à correspondência de 1845, ao Presidente da Província Francisco José de Souza Soares d'Andréa, encontra-se a seguinte informação:

[...] aprovo o expediente de que lançou mão para conseguir a abertura das estradas, que indica, como necessária a comunicação e transito dessa Villa para diversos lugares, providencia esta tanto mais vantajosa, 
quanto com ella se consegue o melhoramento desse Município sem dispêndio dos dinheiros públicos, cujos cofres estão em penúria $[\ldots]^{50}$.

A permanente necessidade de manutenção e abertura das estradas mencionadas nas correspondências nos conduz à própria política fundiária do século XIX, cuja efetivação requeria o alargamento dos espaços transitáveis. Para tanto, a mão de obra indígena se constituía em seu principal suporte. Nesse sentido, é recorrente, nos documentos analisados, a menção de que a utilização do indígena como trabalhador nessas obras representava economia para os cofres públicos. Isso revela um dos aspectos proeminentes da política indigenista de 1845: o caráter "permissivo do recrutamento compulsório de índios para o trabalho público e particular" ${ }^{51}$. Em Cachoeira de Itabuna, o trabalho dos índios era empregado nas obras da estrada e visava facilitar o trânsito de pessoas e o crescimento dos municípios. Os índios eram utilizados como vetor do processo colonizador e civilizatório em curso à época, reconhecendo-se, além disso, “[...] a impossibilidade da conservação e limpeza d'ella [isto é, da estrada] por meio de outros braços que não sejam os dos aldeiados $[. . .]^{\prime \prime 52}$.

Em conformidade com essas assertivas estão os discursos das autoridades imperiais locais, a exemplo do requerimento de verba do Capitão-Mor Antônio Dias de Miranda, de 06 de dezembro de 1826:

50 APEB; Seção Arquivo Colonial e Provincial; Série Judiciário; Maço 2395; Ano 1845.

51 MOREIRA NETO, Carlos de Araújo. Op., cit., p. 258.

52 APEB, Seção Colonial e Provincial; Série Judiciário; Maço n ${ }^{\circ}$ 2396; Ano 1848. 
Antonio Dias de Miranda, Capitão-Mór da Conquista do Certão da Ressaca, tendo, a exemplo de seus antepassados, empregado todos os meios a seu alcance, inda com grande dispêndio de seus bens, perigo de vida própria e de seus parentes [...] a fim de assegmentar a civilização dos gentios bravos aos arredores daquele certão, e segurança das estradas, as felizmente conseguio com grande vantagem, e proveito. Povos, por se acharem já manços os denominados = Mongoiós, e Botocudos =, vê-se em circunstancia de empregar as mesmas deligencias, e fadigas Pr. $^{a}$ com o denominado = Patachó [...] tendo unicamente em vista alongar a civilização daqueles povos, e fazer prosperar a cultura, o sossego dos Habitantes de seu Districto, e mais vizinhos, e a segurança das Estradas; confiando mais que tudo da Integridade, e Benignidade de V. Ex ${ }^{\mathrm{a}}$, submisso, e Respeitoso ${ }^{53}$.

O sucesso do projeto colonizador na região de Ferradas (sem perder de vista que outros aldeamentos foram instalados na região) estava condicionado à "assimilação" dos Camacãs, Pataxós e dos guerens ao processo de catequese nos aldeamento, bem como à manutenção da segurança na estrada, garantindo, assim, os propósitos imperiais relativos à resolução das questões fundiárias à época. Nesse contexto, o funcionamento do aldeamento de Ferradas desempenharia papel estratégico, pois os aldeados, além de fazerM o trabalho de manutenção da estrada, garantiam a segurança dos viajantes e, sobretudo, dos que ali pretendiam se estabelecer. Não é demais insistir, além disso, que, no sul da Bahia, "quanto à ocupação de novos

53 APEB; Seção Colonial e Provincial; Série Agricultura; Maço n ${ }^{\circ} 4613$; Ano 1826. 
espaços, a preferência recaía sobre as áreas dos aldeamentos". ${ }^{54}$

Os aldeamentos instalados ao longo do século XIX, no sul da Bahia, se encontravam sob a administração dos missionários capuchinhos, que, por sua vez, mantinham o diálogo entre si. Isso indica que as autoridades imperiais estavam preocupadas em manter os aldeamentos comunicáveis, com o fim de garantir, de forma mais eficiente, naquela área, a aplicabilidade dos interesses da colonização Oitocentista. Em 04 de maio de 1855, o diretor geral dos índios, Casemiro de Sena Madureira, dirigiu ao Presidente da Província da Bahia, Álvaro Tibeiro de Moncorvo, a seguinte informação:

Representei ao Exm $^{\circ}$ antecessor de V. Ex. ${ }^{a}$ que era necessário authorisar os missionários das aldêas de S. Pedro de Alcantara e os de Catulés e Barra de Catulés a abrirem comunicação fácil entre as [ditas] aldêas para prestarem-se socorros, e facilitarem o comércio com Conquista e Minas pelo Rio Pardo, e fui authorisado a fornecer $400 \$$ reis ao missionário de Ferradas em S. Pedro de Alcantara, e $300 \$$ ao da Barra de Catulés no Rio Pardo para os trabalhos destas estradas por officio de 27 de abril pretérito, tirados de 1:000\$ do cofre geral ${ }^{55}$.

A região, dificilmente, poderia ser considerada como domínio do governo sem o trabalho de pacificação e de disponibilização da mão de obra dos aldeados

54 FREITAS, Antônio Guerreiro de; PARAISO, Maria Hilda Baqueiro. Op., cit., p. 65.

55 APEB; Seção Arquivo Colonial e Provincial; Série Agricultura; Maço 4612; Ano 1855. 
ali territorializados com esse fim. Vale notar que o aldeamento S. Pedro de Alcântara é sempre descrito como "facilitador" do processo de ocupação territorial da região sul da Bahia.

Além do aldeamento de Ferradas, outros aldeamentos aparecem nas documentações do período até a década de 1860, a saber: os da "Barra do Rio Salgado, o do Rio do Salto, o de Barra do Catolé, o do Catolé, o do Cachimbo, o do Salto do Rio Pardo, o de Santo Antônio da Cruz, o da Lagoa do Rio Pardo e o de Pedra Branca" ${ }^{56}$.

Em correspondência de 1848, José Antônio de Sousa Passos, juiz municipal da Vila de Ilhéus, versa sobre as vantagens de se estabelecer outros aldeamentos na Vila de Ilhéus, dando como exemplo o bom desempenho do aldeamento de S. Pedro de Alcântara.

[...] as razões que me fundo são as seguintes.

$1^{\mathrm{a}}$ a vantagem de se conservar sempre limpa e frequentada a estrada que vai d'esta para a Villa da Victoria, que tem por base a conservação e augmento do commercio central, que hoje He nenhum pelo péssimo estado da dita estrada, e falta de abrigo em pontos certos e determinados. $2^{\mathrm{a}}$ o pouco despendio dos Cofres Publicos, por isso que as duas referidas Aldeias podem ser estabelecidas pela maneira que foi a de S. Pedro d'Alcantara, [...] $3^{\mathrm{a}}$ a impossibilidade da conservação e limpêsa d'ella por meio de outros braços que não sejão os dos aldeiados, [...] $4^{a}$ finalmente todas as vantagens que resultão da civilisação dos Indios em geral, que a primeira vista se podem conhecer. ${ }^{57}$

56 ANDRADE, João Cordeiro. Missões Capuchinhas na Comarca de São Jorge dos Ilhéus (1816-1875). Monografia. Ilhéus, UESC, 2003, p. 59.

57 APEB, Seção Colonial e Provincial; Série Judiciário; Maço 2396; Ano 1848. 
Nesses documentos trocados entre autoridades locais e provinciais, o tema da conservação da estrada se configura em uma das principais justificativas para a solicitação de recursos pelas autoridades locais à presidência da província. As correspondências expedidas pelos juízes municipais da Vila de Ilhéus destacam o bom andamento dos trabalhos de limpeza e melhoramento da estrada, bem como o progresso que se tinha alcançado em relação à comunição terrestre entre Ilhéus e Vitória da Conquista.

Tenho presente o officio de V. Exa . De 19 de abril do corrente anno ora recebido, em o qual me ordena, que entregue ao missionário da Aldeia de S. Pedro d'Alcantara Fr. Vicente d'Ascoles, qualquer quantia de 600\$, que eu havia recebido em 22 de Setembro de 1847 para melhoramento e limpesa da estrada que segue d'esta para a Imperial Villa da Vitoria, caso alguma exista em meu poder [...] o methodo empregado sempre e anteriormente a esta ultima limpesa da estrada, tem consistido em desobstruila, já alargando-a, [...] a qual nunca passou de huma picada d'esde que de seo principio foi aberta. ${ }^{58}$

No conjunto das correspondências imperiais, também percebemos diversas manifestações e esforços das autoridades no sentido de oferecer segurança aos que por ali transitavam à época. Conforme explicita a documentação, as condições de funcionamento e uso dessa estrada oscilaram bastante no decorrer do século XIX. Dentre os motivos que culminavam nas dificuldades em manter o bom estado de conservação da estrada Ilhéus-Conquista, destacamos os problemas relacionados ao próprio funcionamento do

58 APEB; Seção Colonial e Provincial; Série Judiciário; Maço 2396; Ano 1850. 
Aldeamento São Pedro de Alcântara. Por ocasião dos intervalos entre as administrações do aldeamento, devido aos momentos de saída de um missionário diretor e chegada de outro, os indígenas aldeados se dispersavam. Isto motivou várias queixas registradas pela diretoria geral dos índios nas correspondências emitidas às autoridades provinciais da Bahia:

Considerando o deplorável estado em q' se acha a V. ${ }^{\text {a }}$ de S. Pedro de Alcantara conhecida pelo nome de $=$ Ferradas do termo desta v. ${ }^{a}$ julgamos de nosso dever levando ao conhecimento de V. Excelência esta occorrencia com as considerações necessárias afim de V. Excelência providenciar conforme entender em sua alta sabedoria. Esse referido lugar das Ferradas, Exm. ${ }^{\circ}$ Snr. ${ }^{\circ}$, q $^{\prime}$ tem sempre merecido as atenções desse Exm. ${ }^{\circ}$ governo mandando para alli já este já aquele Padre missionário afim de catechisar por meio da palavra divina essa parte da espécie humana, indigna, selvagem - embrutecida alli existente denominados Camacães= trazida ao grêmio da Igreja dando-lhes o ensino da civilização, os necessários conhecimentos do justo e injusto, = se acha a pronta no mais completo abandono com a retirada á final do religioso Frei Rainero de Ovada, que teve lugar em julho do anno $\mathrm{PP}^{59}$.

As fontes das décadas de 1840 e 1850 indicam que a conservação da estrada exigia trabalho constante para que o mato não a destruísse. Na década de 1870, a manutenção da estrada continuava sendo uma grande questão, e são intensificados os trabalhos para sua conservação, tendo à

59 APEB; Seção Arquivo Colonial e Provincial; Série Agricultura; Maço 4612; Ano 1859. 
frente os fazendeiros da região, como o estrangeiro Fernando de Steiger, que, segundo correspondência de 1868, empreendia as obras da estrada com sucesso ${ }^{60}$. João da Silva Campos menciona o progresso alcançado em relação aos trabalhos de melhoria da estrada Ilhéus-Conquista na década de 1870. Informa sobre o aumento do trânsito registrado na estrada devido ao bom estado de conservação dela, destacando, ainda, as possibilidades de exploração da agricultura que se abriam em razão do bom andamento das atividades de conservação e abertura da dita estrada:

Frei Luiz de Grava não tinha somente por ocupação administrar a Colônia. Dera-lhe igualmente o governo provincial a incumbência de melhorar a estrada de Ilhéus a Conquista e, pelo seu relatório, apresentado em 1871, vê-se que estava atacado o serviço na extensão de treze léguas, entre a Colônia e a aldeia do Catolé. Neste ano era notável o trânsito de boiadas pela estrada, vindas do sertão para a Colônia e para Ilhéus, sem embargo dos ataques dos índios (718). Prosseguindo na empresa, no ano de 1873 , das 62 léguas totais do caminho faltavam apenas seis para limpar até Ilhéus, e 12 ou 14 até Conquista, sendo os terrenos marginais excelentes para as plantações de café, cacau, cana e algodão ${ }^{61}$.

No fragmento exposto acima, Silva Campos se refere às obras realizadas na estrada, em 1871, ocasião que se encontrava extinto o Aldeamento São Pedro de Alcântara e já funcionava o projeto político de colonização daquela

60 APEB: Seção ArquivoColonial e Provincial, Série Justiça-correspondências juízes de Ilhéus, Maço 2401; Ano 1868.

61 CAMPOS, João da Silva. Op., cit., p. 394. 
localidade, por meio da colônia agrícola denominada Colônia Nacional de Cachoeira de Itabuna ou Colônia Nacional Cachoeira dos Ilhéus.

A partir da extinção do Aldeamento São Pedro de Alcântara, os índios aldeados da região ainda atuavam nas obras da estrada. Serviam ao trabalho de abertura da estrada os aldeados de Cachimbo, aldeamento administrado pelo mesmo frade diretor da Colônia Agrícola Cachoeira de Itabuna, Luís de Grava, aldeamento que, por sua vez, também seria transformado em estabelecimento nacional. Note-se que quando os serviços prestados pelos índios se faziam por recrutamento do Estado, em fins da década 1860, eles trabalhavam na estrada preferencialmente sob o comando e os interesses dos fazendeiros locais. Mostra disso é o registro feito no dia 16 de agosto de 1868, pelo então juiz de direito Antonio Villaça, ao presidente da província, no qual ele mencionava que:

Convencido de que a prosperidade desta Comarca depende absolutamente da estrada que d'aqui se dirige a $\mathrm{V}^{\mathrm{a}}$ da Victoria, e o sertão, a mais perto do litoral, em toda a Costa do Sul da Província: tive a satisfação, pela Resolução d' Assembleia Legislativa Provincial, consignado a quantia de quatro contos de reis, para limpeza da estrada [...] o prestante Estrangeiro Fernando de Steiger, que pretende fazer um estabelecimento importante no Rio Salgado, além das Ferradas, comprando terras do Governo [...]; tenho me com elle empenhado, para que se encarregue da limpeza d'aquella estrada das Ferradas a $V^{a}$ da Victoria [...], e por isso afirmar a V. Excia., que incumbindo-se elle dessa obra, de acordo com o digno Missionário d' Aldeia do Caximbo, Fr. Luis de Grava, se 
conseguirá um serviço de valor, [...] o missionário obtendo trabalhadores para elle de sua Aldeia ${ }^{62}$.

Nesse momento, os aldeamentos da região começavam a ser extintos, a exemplo do de São Pedro de Alcântara. Ao que tudo indica, os antigos aldeados passaram a viver e a trabalhar, a partir de 1870, na Colônia Agrícola fundada nas terras do próprio aldeamento. Nesse período, a lavoura de cacau já estava em ascensão e, por conseguinte, atraía cada vez mais colonos nacionais e estrangeiros. Desse modo, se fazia imperioso o bom uso da estrada Ilhéus-Conquista como ficou evidente na fala do juiz Villaça.

Em outro registro, de 1872, afirma-se "[que] a estrada geral partindo de Ilheos se [dirigindo] para a cidade da Victoria e comarcas visinhas, tem prestado a utilidade que se tinha em vista, transitando por ella grande somma de mercadorias para exportação e importação". ${ }^{63}$ Nota-se, portanto, que ao final do século XIX, com o crescimento econômico da região, o interesse em manter a estrada em pleno funcionamento é mais perceptível, assim como o empenho dos particulares para o bom funcionamento da mesma.

Interessante ressaltar, nesse momento, a relação direta estabelecida entre fazendeiros e missionários. Frei Luis de Grava era o missionário que atuava como diretor da Colônia Agrícola de migrantes e também dirigia o aldeamento denominado de Cachimbo, próximo a Conquista. Ele disponibilizou o trabalho dos aldeados do Cachimbo para os serviços na estrada, cujos serviços de conservação

62 APEB: Seção Arquivo Colonial e Provincial, Série Justiça/correspondências juízes de Ilhéus; Maço 2401; fl.08, Ano 1868.

63 Relatório do presidente da província da Bahia na abertura da Assembleia Legislativa de 1872, p. 143. In: Falas e Relatórios Provinciais Presidenciais (18301930). Disponível em: <http:/ / www.crl.edu/brazil/provincial/ bahia>. 
estavam sob os cuidados do fazendeiro Fernando de Steiger. Isso evidencia não apenas as relações entre missionários e fazendeiros, mas também que o uso da mão de obra indígena era recorrente até o final do século XIX.

No sentido de mapear os estágios de trabalho empregados na estrada, Steiger a dividiu em quatro partes. Isso nos permite visualizar geograficamente a região de Cachoeira de Itabuna nessa época. Assim, no dia 14 de agosto de 1868, Steiger menciona que havia "dividido esta estrada em quatro secções: $1^{\text {a }}$ da Victoria ate o Jacarandá 2 legoas, $2^{a}$ do Jacarandá ao Mutucujê $31 / 2$ ditas, $3^{\text {a }}$ do Mutucujê a Ferradas (São Pedro de Alcântara) 2 ditas, das Ferradas ao Rio Salgado 3 ditas". Nesse momento, o aldeamento já se encontrava extinto, mas aparece entre parênteses, na citação à Ferradas, pela clara correlação que as pessoas ainda faziam entre Ferradas e o aldeamento dos índios.

$\mathrm{Na}$ sequência do documento, Fernando de Steiger menciona o lugar denominado Tabocas, que, segundo ele, ficava entre Mutucugê e Ferradas, localizando-se a 1 légua acima de Mutucugê, local povoado por pequenas fazendas de cacau que prosperavam. Até os dias de hoje, Itabuna é denominada, pelos mais antigos, com o nome de Tabocas, um dos primeiros nomes do povoado que daria origem à atual cidade de Itabuna, e que nomeia um dos livros memorialistas mais importantes daquela cidade: O Jequitibá da Taboca, de Oscar Ribeiro Gonçalves. Pelas evidências do documento citado acima, concluímos que Cachoeira de Itabuna e Tabocas eram um mesmo núcleo, pois se tratava, justamente, da povoação próxima a Ferradas, como explicita Steiger.

Steiger segue seu relato sobre o andamento das obras e a forma como estava dividindo o trabalho na estrada, bem como as previsões de conclusão da mesma. Dentre as informações deixadas por ele, vale citar o emprego de "1672 jornaes d'escravos" para cumprir a primeira seção 
da estrada, que partia de sua fazenda Vitória. Cita ainda o emprego de 65 dos seus escravos nos serviços da terceira seção da estrada que, não por acaso, compreendia a área entre Mutucugê e Ferradas, ou seja: Tabocas. Isso demonstra o interesse particular em manter a estrada bem conservada, naquela região específica.

Observamos, mais uma vez, o caráter de fluidez da fronteira social que permeava aquela região e seu processo histórico de conquista e colonização, no qual atuavam religiosos, autoridades governamentais, colonos, índios aldeados e escravos ${ }^{64}$, pois a $3^{\mathrm{a}}$ seção da estrada, que compreendia a região de Cachoeira de Itabuna (Tabocas), estava sendo mantida pelo trabalho em comum dos índios aldeados da região e dos escravos de Steiger.

Dissertar sobre a relevância do trabalho indígena na estrada para garantir o êxito da política imperial na região de Cachoeira de Itabuna, bem como sobre a utilização de sua mão de obra na pacificação territorial se mostra relevante, pois permite perceber como o sul da Bahia se beneficiava da política indigenista para fins de colonização, durante o século XIX. Além disso, a manutenção dos aldeamentos e da estrada justificava a contínua solicitação de recursos por parte do governo local ao governo provincial. Eram esses recursos que muitas vezes garantiam a autonomia administrativa da vila.

64 Caracterizamos a região sul da Bahia como região de fronteira a partir do aparato teórico que trata este conceito mais especificamente para os estudos indígenas: João Pacheco de Oliveira (1998), Maria Regina Celestino de Almeida (2001; 2013) e Vânia Losada Moreira (2010; 2011), que trataram da questão da construção da identidade do índio no mundo territorializado, processo no qual as fronteiras étnicas entre aldeados e colonizadores são mantidas na interação. Nesse bojo de reflexão teórica sobre fronteira, são fundamentais os direcionamentos teóricos de Frederik Barth (2011)- Grupos étnicos e suas fronteiras- como referência fundamental para pensar a ideia de fronteira étnica entre os grupos sociais em situação de contato. 
Entretanto, procuraremos demonstrar a atuação dos homens e mulheres em "situação de aldeamento" de Ferradas em outros postos de trabalho, tais como os trabalhos de fabricação de canoas e na navegação e, especialmente, nas fazendas e na lavoura de cacau. Tal abordagem permite vislumbrar a importância dos índios no processo de desenvolvimento econômico daquela região e, em algumas ocasiões, a sua capacidade de negociar a própria mão de obra.

Em correspondência não assinada pelo remetente, de 04 de agosto de 1849, enviada à presidência da província, informando sobre requerimento de índios "botocudos", encontramos a seguinte informação:

Disem os Botocudos moradores nas mar-
gens do Rio Pardo, e suas adjacências que
desejando elles supplicantes de se reuni-
rem na sua primitiva terra situada entre o
riacho Catulé, e o de S. Pedro, e alli na beira
do mesmo rio formarem a sua aldea, a co-
adjuvarem com sustento, e braços as cano-
eiras da importantíssima navegação do Rio
Pardo $^{65}$.

Assim como a estrada, a navegação dos rios que compreendiam o sul da Bahia era de fundamental importância para a mobilidade de pessoas e o escoamento de produtos naquele processo de colonização. Nesse contexto, o transporte por meio de canoas era uma atividade importante, e os indígenas, habitantes daquelas paragens, sabiam perfeitamente a relevância da sua mão de obra especializada em fabricar canoas e em servir como navegadores nos rios.

65 APEB; Seção: Arquivo Colonial e Provincial, Série: Juízes de Ilhéus / 1840-1850; Maço 2396; ANO 1849. 
No fragmento citado, observamos claramente a negociação proposta pelos botocudos. Em troca de se estabelecerem em terras que lhes pertenciam historicamente, ofereciam ao colonizador serviços indispensáveis que eles sabiam fazer melhor do que ninguém: construir canoas e trafegar os rios que eles conheciam perfeitamente bem e não raramente tornavam navegáveis. Em 05 de dezembro de 1850, a inspetoria da tesouraria provincial enviou à presidência da província o requerimento de frei Vicente Maria de Ascoli, diretor de São Pedro de Alcântara. Registrava-se "que em vista dos serviços prestados ao Ex. governo pelos índios da sua aldeia tanto para fazer navegável o Rio Caxoeira do ponto chamado Mutucugê até as Ferradas; abrindo treis legoas; como em marcar a estrada de comunicação entre a Villa da Victoria, e a dos Ilheos" ${ }^{\prime \prime 6}$, seria por bem que a presidência lhe mandasse fornecer ferramentas de trabalho, roupas, chumbo e pólvora.

Essas observações feitas acerca da documentação disponível são imprescindíveis para percebermos como de fato se dava a relação entre aqueles dois mundos, o do colonizador, que se utilizava da mão de obra indígena para tornar possível o projeto de expansão dos limites da província, e o do indígena, "em situação de aldeamento" ou não, que sabia a hora de negociar com os colonizadores para fazer valer seus interesses naquele processo. Sendo assim, concordamos com Marcelo Henrique Dias, que em seus estudos sobre os aldeamentos coloniais jesuíticos, na capitania de Ilhéus, destaca a proeminência do trabalho indígena, em contraponto a uma historiografia que prefere insistir no poder de "devastação" Aimoré. Segundo as palavras do autor:

66 APEB, Seção Arquivo Colonial e Provincial, Série Agricultura; Maço 4613; Ano 1850. 
De modo geral, a historiografia que direta ou indiretamente trata da capitania de Ilhéus tem colocado suas populações indígenas, sobretudo aimorés e pataxós, na qualidade de principais obstáculos ao desenvolvimento de sua colonização. Já no final do primeiro século da colonização, os aimorés teriam arrasado os engenhos da vila de São Jorge e condenado a mesma a uma decadência que se estenderia até o século XIX. ${ }^{67}$

Os indígenas habitantes do sul da Bahia, no século XIX, também aparecem como entraves ao processo "civilizador", sobretudo na escrita memorialista regional, a exemplo das obras memorialistas de Oscar Ribeiro Gonçalves e José Dantas de Andrade, para quem os índios se configuravam em obstáculos que os "pioneiros" tratariam de superar ${ }^{68}$. Tal descrição, contudo, em nada é compatível com as informações colhidas nos arquivos, pois o que acontecia na prática das relações ali estabelecidas era um processo de luta de interesses, complexo o suficiente para

67 DIAS, Marcelo Henrique. Op., cit., 2007b, p. 188-189.

68 Oscar Ribeiro Gonçalves, ao tratar da chegada dos imigrantes sergipanos Félix Severino do Amor Divino e Manoel Constantino à Ilhéus, observa o contato com os índios como obstáculo que os imigrantes teriam que superar e, ressalta que ambos, "sozinhos neste dito lugar êrmo [às margens do Rio Cachoeira], como teriam eles contemplado aquele cenário?... A mata, os caboclos e as feras eram seus únicos vizinhos": GONÇALVES, Oscar Ribeiro. $\mathrm{O}$ jequitibá da Taboca. Ensaios históricos de Itabuna. Itabuna: Oficinas gráficas da Imprensa Oficial da Bahia, 1960, p. 28-29. Na descrição apresentada por José Dantas de Andrade: "Nos raros encontros entre índios e desbravadores, a vitória ficava sempre com os segundos, obrigando a que os silvícolas, compreendendo a inutilidade de suas flechas contra as espingardas [...], fossem se aprofundando cada vez mais nas matas, cedendo terreno ao avanço dos brancos". ANDRADE, José Dantas de. Documentário histórico ilustrado de Itabuna. Itabuna: Gráfica Editora Itabuna LTDA, 1968, p. 21. 
pugnarmos a assertiva de que o índio era apenas um obstáculo a ser vencido. Afinal, se é verdade que os índios podiam resistir e até mesmo destruir fazendas, criações e vidas, não é menos certo que, quando aldeados, frequentemente serviam aos propósitos da colonização.

$\mathrm{Na}$ correspondência de 11 de março de 1849, ao presidente da província Franco Galvão Martino, o juiz municipal substituto da Vila de Ilhéus, Christiano Manoel de Sá Belsamara, são mencionados os prejuízos de se fazer uma nova missão nas proximidades de Ferradas. Para ele, isso significava a perda da mão de obra indígena para trabalhar nas áreas rurais do município de Ilhéus:

Tenho a saptisfação em comunicar a V. Exa , que o Padre Frei Vicente Micionario das Ferradas, accaba de fazer um mui importante serviço a este Municipio. A estrada de comunicação para os Certões achava-se intransitável por diversos attentados praticados pelos índios Camacans, como sejão intrepes para offensa dos passageiros, attaques as fazendas cituadas na mesma estrada, mortes de animais e mesmo de indivíduos. Frei Vicente ciente destas noticias posse a marcha, acompanhado de frei Joaquim de Colorno, leigo, de um língua, e dois guias; e depois de muitos dias [...] alcansou os Camacans reprehedeu seus crimes, e redusio 62 a virem aldeiarem-se nas Ferradas. [...] encontrei aqui Frei Ludovico com outro frade, que marcharão em direção ao centro dos Certões, hindo pelo Rio Pardo, para estabellecerem uma misção, de que tomará conta o dito frade. [...] eu a julgo inteiramente opposta aos intereces d'este Municipio, pois que vai roubar lhe grande número de braços livres, que podem cultivar seus terrenos. Frei Vicente [...], pode em pouco tempo com 
a pretensão de V. Ex ${ }^{\mathrm{a}}$, domesticar os Camacans, sem ser precisa outra Missão [...]. ${ }^{69}$

O juiz segue o seu relato observando que, quando chegou frei Vicente a Ferradas, com os índios, frei Ludovico os esperava para transferi-los para uma área próxima ao rio Pardo, onde instalaria outro aldeamento com os mencionados Camacãs. Em tom de protesto, o juiz substituto de Ilhéus defendia que os Camacãs deveriam ficar em Ferradas. Para ele, assim como frei Vicente havia conseguido convencer aqueles Camacãs a aldearem-se, poderia igualmente aldear outros camacãs em Ferradas, com a ajuda financeira do governo provincial. O juiz lembra ao Presidente Franco Galvão que frei Ludovico "nunca pôde amansar os Camacans, e [desce-los] a aldeiarem$\mathrm{se}^{\prime \prime 70}$. Belsamara apelava para o prejuízo que representaria, para Ilhéus, a retirada dos índios camacãs, pois se tratava de mão de obra livre (em termos jurídicos) que poderia cultivar as fazendas instaladas na região. $\mathrm{O}$ documento não deixa pistas evidentes sobre a posição dos camacãs nessa contenda, mas a tensão emergida daquele episódio permite inferir a possibilidade de considerar que os próprios camacãs se recusavam a ficar em Ferradas, pois Belsamara lembrou a sua resistência a aldearem-se no tempo em que Ludovico havia sido diretor da aldeia de Ferradas.

Portanto, nas relações estabelecidas no processo do contato e instalação de aldeamentos na região sul da Bahia, é interessante notar, conforme permite observar o documento, que o local de fundação de um aldeamento nem

69 APEB; Seção Arquivo Colonial e Provincial; Série Judiciário; Maço 2396; Ano 1849.

70 APEB; Seção Arquivo Colonial e Provincial; Série Judiciário; Maço 2396; Ano 1849. 
sempre era escolhido à revelia dos índios. $\mathrm{O}$ documento indica suas interferências nesse processo, no qual os colonizadores, muitas vezes, tinham que negociar com eles o local de funcionamento de um novo aldeamento. Isso demonstra claramente que os índios tinham seus próprios interesses quando da sua inserção em um aldeamento.

Um dos aspectos latentes emergidos da fala de Belsamara, nesse documento, diz respeito à influência político-administrativa de frei Ludovico em toda a região, visto que o frei atua no episódio com plena autoridade sobre os aldeados de Ferradas, embora não fosse seu administrador oficial. Ao que tudo indica, sua atuação na região, por mais de três décadas, lhe conferiu poder de articulação política, legitimando-o como um dos principais interlocutores dos interesses tanto do governo quanto de particulares naquela parte do sul da Bahia.

A decisão de Ludovico, de transferir os indígenas de Ferradas para a região do rio Pardo, incomodou as autoridades locais, a ponto de Belsamara protestar ao presidente da província com uma queixa contra o frade. Isso abre uma janela para as disputas por mão de obra indígena da época, bem como para o lugar político ocupado por frei Ludovico, que aparece como o principal administrador e distribuidor do trabalho dos homens e mulheres em "situação de aldeamento" na região.

Outro exemplo da administração do trabalho dos índios aldeados do sul da Bahia por parte dos capuchinhos e, de certa forma, da pedagogia de catequese utilizada por eles, que estava calcada em grande medida, em moldá-los ao trabalho, é o ofício do Frei Rainero de Ovada, de 1852, no seu exercício de diretor da aldeia de Catolé:

Sobre a petição de fr. Rainero de Ovada, missionário dos índios Mongoiós de Catulés, na qual requer a diária de $500 \$$ para um 
indivíduo que o ajuda incessantemente na direção dos trabalhos agrícolas a que precisa acostumar os índios e na catequese, ensino da doutrina cristã só há de aparecer que é muito necessário esse ajudante e que sirva principalmente de feitor para os trabalhos do campo nos quais os índios que são muito indolentes e não prosperam senão aguilhoados por um feitor que não os deixe nem por um momento durante o serviço ${ }^{71}$.

\begin{abstract}
Acerca do trabalho dos aldeados de Ferradas nos serviços dos particulares da região, assinalemos algumas observações possíveis a partir do artigo do francês $\mathrm{H}$. Perret, intitulado "Aldeia do Bom Padre", publicado no jornal $O$ Crepúsculo durante o ano de 1846:
\end{abstract}

Os indígenas que naquelles contornos residem procedem de tribus diversas; ha entre elles muitos Camacans, mormente nas imediações de Ermo-nobre, bella plantação de cacao do Sr. Weyll, porém estes já se achão civilisados de todo, principalmente as mulheres: os d'entre elles que são mais laboriosos podem ser utilmente empregados nas roçadas, e na extração de madeiras, e aquelles que pelas matas errão, não deixam de offerecer algum recurso aos fazendeiros, por apparecerem de vez em quando com abundante caça, que trocão por algumas bebidas espirituosas: alli a caxaça he a moeda corrente $^{72}$.

71 Seção Arquivo Colonial e Provincial; Ofício do diretor geral dos índios. Casemiro de Sena Madureira, de 9 de novembro de 1952. Apud SOUZA, Telma Mirian Moreira de. Op., cit., p. 168.

72 CEDOC; PERRET, H. Jornal O Crepúsculo: Salvador, edição n ${ }^{\circ}$ 13, ano 1846, p. 190. 
Pedro Weyll era o alemão que outrora havia estado à frente da tentativa de formação da colônia de alemães denominada Colônia de São Jorge da Cachoeira de Itabuna, às margens do Rio Cachoeira, assunto do qual já tratamos no capítulo anterior. A documentação demonstra que Weyll não desistiu de fazer vingar os seus empreendimentos na região, visto que, na década de 1840, ele estava instalado na região do Almada, localidade denominada de Ermo-Nobre, com fazenda de cacau. Na fazenda do estrangeiro, os Camacãs descritos como já totalmente civilizados, supomos serem os Camacãs de Ferradas, tendo em vista a sequência do registro:

[...] Vimo-nos portanto na precisão de ir com a nossa canoa até o porto das Bananeiras, onde saltamos, afim de nos dirigirmos por terra à um ponto do mesmo rio, situado acima da cachoeira em que outra canoa nos esperava para nos conduzir a Ermo-nobre. Tanto neste lugar, como em Castelo-novo, recebemos o mais cordial acolhimento dos Srs. Pedro Weyll e Scola. Admiramos a plantação de cacao do primeiro, e os melhoramentos que o Engenho de assucar devia já ao segundo [...]. Os Indios Camacans que lá vimos, e o elogio que se nos fez d'aquelles que residião nas Ferradas, muito augmentaram a impaciência que tínhamos, de visitar a aldeia fundada, há mais de trinta anos, nas margens do rio Cachoeira ${ }^{73}$.

Os fragmentos citados acima confirmam a participação direta que tiveram os aldeados de São Pedro de Alcântara na implantação e manutenção do cultivo do cacau nas fazendas da região sul da Bahia. Atuavam não apenas em Cachoeira de Itabuna, visto que o registro atesta a participação deles

73 CEDOC; PERRET, H. Jornal O Crepúsculo: Salvador, edição $\mathrm{n}^{\circ} 13$, ano 1846, p. 191. 
nas fazendas da região do rio Almada. Ermo Nobre e Castelo Novo foram núcleos agrícolas importantes em Ilhéus do século XIX, que se converteram em núcleos de povoamento, posteriormente. Aqueles estrangeiros, para quem os camacãs trabalhavam, se constituíram nas famílias mais ricas da região, responsáveis, em grande medida, pelos rumos políticos e econômicos de Ilhéus e Itabuna no início do século XX. A exemplo dessas famílias, mencionamos os Lavigne, que também se utilizavam do trabalho dos aldeados de Ferradas:

[...] eis-nos de novo na Esperança, e já os nossos amigos Level e Roberto Lavigne preparão os cavallos que devem transportarnos às Ferradas [...]. Quando os nossos amigos naquelle lugar se estabelecerão, já havia annos que o Rev. Ludovico se achava nos bosques, tinha dado principio à civilização dos Camacans, e fundado a Aldeia de S. Pedro d'Alcântara, ou Ferradas, como costumão chama-la. Aquelles Indios forão diversas vezes empregados, e com vantagem, nas obras executadas pelos novos habitantes da Esperança, que sempre achavão nelles zelo, e fidelidade, porque também da sua parte cumprirão com exatidão as promessas feitas àquelles bons indígenas; o que, seja dito entre parenthesis, nem sempre acontece, e eis a causa principal da repugnância que a mor parte dos Indios mostrão para o trabalho ${ }^{74}$.

Nota-se, portanto, o interesse dos colonos estrangeiros nas terras do sul da Bahia, bem como o largo uso do trabalho dos indígenas de Ferradas em suas fazendas. $\mathrm{O}$ último

74 CEDOC; Jornal O Crepúsculo: Salvador, edição nº 13, ano 1846, p. 192. 
fragmento citado nos permite supor pelo menos três aspectos importantes da relação entre ocupação territorial e trabalho indígena, no sul da Bahia, quais sejam: primeiro, os Lavigne se estabeleceram ali quando o aldeamento São Pedro de Alcântara já atuava na região, demonstrando, mais uma vez, que o aldeamento funcionava estrategicamente para garantir o sucesso da colonização; segundo, manifestação do avultado uso do trabalho dos aldeados de Ferradas nas fazendas instaladas não apenas em Cachoeira de Itabuna, mas em grande parte da região; terceiro, podemos observar, ainda que superficialmente, como se dava a relação de trabalho entre índios e fazendeiros.

Perret afirma que os índios de São Pedro de Alcântara haviam sido empregados muitas vezes nos trabalhos da fazenda Esperança e, "com vantagem". Ele também elogia os Lavigne por cumprirem as promessas feitas aos índios e menciona o histórico de exploração indevida do trabalho deles por outros moradores. $\mathrm{O}$ documento não evidencia como se dava a negociação de trabalho entre os Lavigne e os aldeados de Ferradas, no entanto, fica claro que eles faziam acordos com os índios, como fica explícita, também, uma realidade de exploração em moldes compulsórios do trabalho dos aldeados por parte dos fazendeiros da região.

No conjunto das correspondências analisadas, notamos que quando os índios eram pagos pelo trabalho público realizado, o eram em roupas, ferramentas agrícolas, dentre outros bens de consumo, como no caso em que o frei Vicente Maria de Ascoli solicitou ao presidente da Província, que disponibilizasse ferramentas de trabalho, roupas, pólvora e chumbo em vista dos serviços prestados pelos aldeados na estrada e na desobstrução dos rios ${ }^{75}$.

75 APEB; Seção Arquivo Colonial e Provincial; Série Agricultura; Maço 4613; Ano 1850. 
Contudo, também existia a possibilidade da coerção e castigo físico, como podemos observar na correspondência do frei Rainero de Ovada, citada anteriormente, na qual ele solicitava um feitor para ajudá-lo a obrigar os índios ao trabalho. Além disso, Perret menciona que "alli a caxaça he a moeda corrente"76. Também Maria Hilda Paraíso, em seu estudo, menciona que Peter Weyl [Pedro Weyll] se utilizava do trabalho dos índios remanescentes do antigo aldeamento do Almada em troca de cachaça ${ }^{77}$. Em outras palavras, naquela realidade, certa abertura para a negociação do trabalho indígena era tão possível quanto a sua exploração de forma compulsória, não remunerada e forçada.

Em contrapartida, podemos observar que os índios não aceitavam a exploração do seu trabalho de forma passiva. Podemos notar, nas palavras de Perret, que a mencionada preocupação daqueles fazendeiros em cumprir os acordos estabelecidos (embora seja bem provável que o contradito fosse verdadeiro), perdurava, porque, caso contrário eles não teriam a mão de obra dos aldeados à sua disposição, pois, como Perret mesmo lembra, muitas vezes os índios se negavam a trabalhar para os fazendeiros.

O testemunho da documentação compulsada para esta pesquisa, que desenha claramente os índios como trabalhadores das roças de cacau, contradiz o que Mahony afirma sobre a ausência do trabalho indígena na lavoura do cacau no sul da Bahia, durante o século XIX. Mais preocupada em demonstrar a relevância da mão de obra escrava na lavoura cacaueira, a autora afirma que os indígenas, naquele momento, assim como no período colonial, não se ocupa-

76 CEDOC; PERRET, H. Jornal O Crepúsculo: Salvador, edição n ${ }^{\circ} 13$, ano 1846, p. 190.

77 PARAISO, Maria Hilda Baqueiro. Op., cit., 1998, p. 319. 
ram muito dos trabalhos nas fazendas ${ }^{78}$. Do nosso ponto de vista, a assertiva de Mary Mahony confirma, sem explorar as complexidades da questão, o que é recorrentemente veiculado na historiografia e já foi criticado por Dias: a "tão propagada incompatibilidade cultural dos índios com o trabalho sistemático"79. Ao invés disso, o autor afirma que os aldeamentos "constituíram-se como parte integrante de um sistema produtivo muito original que se desenvolveu na capitania, o qual articulava à agricultura de gêneros alimentícios, sobretudo da mandioca para farinha, a extração e beneficiamento de uma gama de produtos vegetais", ${ }^{80}$ produtos esses importantes para o mercado interno da região:

[...] as madeiras de lei destinadas à construção naval e civil do Reino e de Salvador; a manufatura de produtos de extração local, como estopas de embiras e cabos de piaçava usados na navegação, na construção naval e nos arrastos de toras de madeira nas áreas de corte; a extração das cascas de mangue para serem usadas nos curtumes que processavam os couros usados nas embalagens de tabaco que seguia para a África; a manufatura de caixas de taboado para exportação do açúcar; e o artesanato com coquilhos, casco de tartaruga etc ${ }^{81}$.

A preocupação de Marcelo Dias em observar a participação indígena no comércio da Capitania de Ilhéus, tecendo suas ponderações sobre a relevância do trabalho dos aldeamentos jesuíticos em "atividades produtivas

78 MAHONY, Mary Ann. Op., cit., 2001, p. 98.

79 DIAS, Marcelo Henrique. Op., cit., 2007b, p. 185.

80 IDIAS, Marcelo Henrique. Op., cit., 2007b, p. 205-2.

81 Idem, p. 206. 
agrícolas, extrativistas e artesanais" ${ }^{82}$, de forma a azeitar o comércio entre a Capitania e o Recôncavo, bem como seus questionamentos acerca de uma assertiva da produção indígena apenas para subsistência no espaço do aldeamento, abre uma janela para pensarmos a atuação indígena aldeada do século XIX na dinâmica da economia regional.

Da mesma forma, as ideias de Stuart Schwartz acerca do reconhecimento do trabalho indígena nos anos coloniais na Bahia, que analisa o uso da mão de obra indígena ao lado do trabalho escravo nos engenhos, iluminam nosso interesse em pensar o trabalho indígena durante os anos imperiais. Schwartz analisa o acesso ao trabalho indígena nos primeiros tempos da colonização com a implantação da "grande lavoura" e que perduraria de diferentes formas por grande parte do período colonial. Nesse sentido, o autor destaca três estratégias estabelecidas para o emprego da mão de obra indígena na lavoura dos engenhos de açúcar: a escravização; a tentativa de "criação de um campesinato indígena" implementada por ordens religiosas, sobretudo a dos jesuítas; por último, o esforço de tornar os índios trabalhadores assalariados ${ }^{83}$. Schwartz salienta que "nos engenhos baianos, a escravidão, o trabalho dos índios das aldeias jesuíticas, o escambo e o assalariamento existiram simultaneamente" 84 . Isso significa dizer que, para Schwartz, a interação indígena com o mundo colonial permanecia, por meio de diferentes estratégias de uso da sua mão de obra, mesmo após a substituição do trabalho indígena pela mão de obra escrava africana na lavoura do açúcar.

\section{Idem, p. 205.}

83 SCHWRTZ, Stuart B. Segredos internos: engenhos e escravos na sociedade colonial, 1550-1835. Tradução Laura Teixeira Motta. São Paulo: Companhia da Letras, 1988, p. 45.

84 Idem, p. 60. 
John Monteiro não só revisa a ideia simplista disseminada pela historiografia, de que o trabalho escravo dos índios teria papel transitório e secundário, como demonstra que a colonização de São Paulo desenvolveu e procurou "garantir a preservação de uma forma muito particular de escravidão" 85 . Para o autor, o desafio era explicar "por que e como" a escravidão indígena norteou as práticas escravagistas e se configurou como a "forma de produção predominante" em São Paulo ${ }^{86}$. Em seu estudo, o papel das populações indígenas ocupa lugar central para pensar a organização da economia colonial paulista, processo "no qual diversas e distintas sociedades indígenas ficaram subordinadas a uma estrutura elaborada visando controlar e explorar a mão de obra indígena" ${ }^{17}$. Celestino de Almeida corrobora as asserções de Schwartz e Monteiro acerca da importância de se repensar o trabalho indígena no período colonial. A autora observa que, diferente da ideia de que o trabalho indígena tenha sido usado de forma transicional, no Rio de Janeiro, a mão de obra indígena teve papel fundamental "nos dois primeiros séculos da colonização" e funcionou ao lado do trabalho escravo africano ${ }^{88}$.

Monteiro observa um duplo movimento no panorama econômico do século XVII. Ele infere que, nesse século, com a ascensão da economia açucareira nas capitanias da Bahia, Pernambuco e Rio de Janeiro e subsequente crescimento da população, houve escassez de produtos de abastecimento para as zonas produtoras do açúcar, de forma que ficou a cargo das zonas não produtoras do açúcar suprir esse espaço. Desse modo, o autor frisa que São Paulo,

85 MONTEIRO, John Manuel. Op., cit., 1994, p. 130.

86 MONTEIRO, John Manuel. Op., cit., 1994, p. 129.

87 Idem, p. 9.

88 ALMEIDA, Maria Regina celestino de. Op., cit., 2013, p. 218. 
o sul da Bahia, Espírito Santo e Maranhão foram responsáveis pelo abastecimento de produtos agrícolas num "circuito comercial intercapitanias". Em consequência disso, outro movimento se evidencia: a intensificação do recrutamento do trabalho indígena ${ }^{89}$.

Nessa perspectiva, Marcelo Dias sustenta a tese de que a capitania de Ilhéus tinha uma característica peculiar, atendendo a uma dinâmica de produção que garantisse o abastecimento do mercado interno. Discorda da tese de "falência da Capitania" pelo fato de ela não se enquadrar no modelo colonial de produção açucareira ${ }^{90}$ e considera a participação indígena da Capitania em outras frentes de organização do trabalho. $\mathrm{O}$ autor privilegia a análise do trabalho dos aldeamentos jesuíticos em atividades produtivas integradas "ao sistema econômico que envolvia a Capitania como um todo, o qual, longe de ser insignifican$\mathrm{te}^{\prime \prime 91}$, apenas destoava da predominância da economia do açúcar observada em outras capitanias da Colônia.

As observações de Schwarcz, Monteiro, Almeida e Dias demonstram as complexas relações e interações dos colonizadores com as populações indígenas e o uso de

89 MONTEIRO, John Manuel. Op., cit., 1994, p. 100.

90 Cf. DIAS, Marcelo Henrique. A capitania de São Jorge dos Ilhéus: economia e administração. In: DIAS, Marcelo Henrique; CARRARA, Angelo Alves (Orgs.). Um lugar na história: a capitania e comarca de Ilhéus antes do cacau. Ilhéus: Editus, 2007, p. 59: o fato de não se ter desenvolvido plenamente na Capitania [de Ilhéus] a economia do açúcar, não significou um estado crônico de miséria e isolamento para todo o seu território. Pelo contrário, a necessidade de manter um polo produtor de alimentos próximo às zonas agro-exportadoras de forte concentração populacional [...] levou a administração colonial a tomar uma série de medidas no intuito de evitar a expansão dos engenhos e das lavouras de tabaco na capitania de Ilhéus, ao mesmo tempo em que orientava os colonos, inclusive com medidas radicalmente opressivas, para a produção da mandioca - o pão da terra - e de outros gêneros alimentícios.

91 Idem, p. 232. 
sua mão de obra durante o período colonial. Para a realidade do sul da Bahia oitocentista, observamos, na documentação compulsada e analisada, uma dinâmica de uso do trabalho indígena aldeado que os coloca no centro da configuração regional de emergência da lavoura do cacau. Ou seja, os índios de Ferradas desenvolviam atividades de agricultura no próprio aldeamento; plantavam o milho, o arroz, a mandioca, o algodão, o café, dentre outros produtos agrícolas, mas também atuavam na lavoura cacaueira de forma direta e indireta.

Ainda não podemos discutir de forma aprofundada as condições de trabalho dos indígenas nas fazendas de cacau, durante o século XIX, visto que a documentação em uso nos fornece pistas muito frágeis com relação a essa realidade. Contudo, lembramos que o regulamento de 1845 , através do processo catequético nos aldeamentos, visava transformar os índios em trabalhadores, seguindo as premissas do Diretório Pombalino. O Decreto que abolia o Diretório Pombalino garantia a permanência do caráter "permissivo do recrutamento compulsório de índios para o trabalho público e particular" ${ }^{22}$ Sendo assim, os direcionamentos para o trabalho indígena, na região sul da Bahia, conforme permite observar a documentação, estavam embutidos nas práticas de uso compulsório, não remunerado ou forçado do trabalho das populações indígenas aldeadas.

Portanto, não podemos inferir com clareza as relações de trabalho estabelecidas naquele processo, mas vale ressaltar que a documentação faz supor a importância das populações indígenas do sul da Bahia no processo de implantação e consolidação da lavoura do cacau na região, pois, foi com o trabalho direto e indireto dos índios que a lavoura de cacau foi implantada na região

92 MOREIRA NETO, Carlos de Araújo. Op., cit., p.258. 
sul da Bahia e também foi por meio do auxílio deles que a região se transformou, pouco depois, em um dos maiores expoentes do cultivo e da exportação do cacau, ao final do século XIX e início do século XX. Buscando sustentar nossa argumentação, retomamos a fala presidencial de João Maurício Wanderley. Na abertura da Assembleia Legislativa, no dia $1^{\circ}$ de março de 1853 , o presidente se pronuncia sobre os aldeamentos existentes na Província da Bahia, e destaca que:

[...] o principal e mais importante destes aldeamentos he o de São Pedro d' Alcântara, situado à margem septentrional do rio Cachoeira, 12 legoas acima da Villa de Ilhéos [...], tem hoje por missionário e director Fr. Vicente de Ascolis, dotado de muita energia que tem chamado os índios ao trabalho com perseverança, fazendo-os plantar mais de vinte mil pés de café e vinte mil de cacao, e produzir farinha, arroz e feijão bastante para alimentação das 38 famílias da tribu Camacan, que ali há $[. .$.$] , o que prova que$ esta aldea prospera (Grifo nosso ${ }^{93}$.

O fragmento citado é revelador da atuação dos homens e mulheres em "situação de aldeamento" em São Pedro de Alcântara. $\mathrm{O}$ documento atesta que o aldeamento participava ativamente da lavoura do cacau como produtor de significativa quantidade de pés de cacau e café. Nem no período colonial, como demonstrou Dias, nem em Ferradas o trabalho agrícola dos índios reduziu-se à produção destinada apenas para o atendimento da própria subsistência ${ }^{94}$.

93 Fala que recitou o presidente da província da Bahia, João Maurício Wanderley, $1^{\circ}$ de março de 1853, p. 35. In: Relatórios Provinciais Presidenciais (18301930). Disponível em: <http:/ / www.crledu/brazil/provincial/bahia>.

94 DIAS, Marcelo Henrique. Op., cit., 2007b, p. 185. 
A documentação nada diz, contudo, sobre o que era feito com o cacau e o café plantados pelos índios, especialmente sobre como eram administrados os lucros e quem, efetivamente, beneficiava-se e usufruía dos rendimentos. A questão é importante porque, em avaliação sobre a dimensão da plantação de cacau na região sul da Bahia para a década de 1880, Mahony pontua que as plantações grandes, que depois se configurariam nas fazendas dos homens mais ricos da região, compreendiam um total de 100 mil ou mais pés de cacau; e as plantações intermediárias compreendiam de 5 a 10 mil pés de cacau ${ }^{95}$. Desse modo, uma plantação de 20 mil pés de cacau, quando a média de uma propriedade intermediária correspondia, no final do século, à metade do que existia no Aldeamento São Pedro de Alcântara, já na década de 1850, nos permite afirmar que a produção de cacau no aldeamento era bastante significativa, inserindo os índios na dinâmica da economia da região.

Se recuperarmos o envolvimento e interesse pessoal de Balthazar da Silva Lisboa na instalação do Aldeamento de Ferradas, demonstrado no II capítulo, podemos inferir que não era apenas a mão de obra indígena, administrada para atender aos interesses dos fazendeiros locais, que despertava o interesse dos moradores, mas aventamos que o próprio aldeamento suscitava o interesse empreendedor dos particulares.

Nesse curso dos acontecimentos, a expressiva produção de cacau do Aldeamento São Pedro de Alcântara demonstra que os índios não só estavam ocupados em cultivar cacau nas terras dos colonos, como também nas terras do próprio aldeamento. Sendo assim, algumas

95 MAHONY, Mary Ann. Op., cit., 2001, p. 108. 
questões são suscitadas: em que medida os aldeados participavam da receita gerada pelo cacau produzido no perímetro do aldeamento, produto que na década de 1850, já era exportado? Quem lucrava? Algum benefício ficava com os índios ou com o aldeamento? Como atuavam os índios, o governo e os capuchinhos, nesse processo? Não podemos tecer as possíveis respostas apenas a partir da documentação utilizada no estudo até aqui desenvolvido. Essas são elucubrações a serem exploradas, mas que não encontram respostas satisfatórias na documentação compulsada para realizar este estudo. No entanto, nossa documentação deixa clara a teia de relações estabelecidas entre índios e não índios no contexto do trabalho na lavoura do cacau, no sul da Bahia, durante o século XIX.

Não é nossa intenção afirmar que os Camacãs e os Guerens de Ferradas e os homens e as mulheres dos demais aldeamentos do sul da Bahia foram a mão de obra motriz para a lavoura do cacau em ascensão; tampouco que tenham fundado latifúndios do cacau. Nosso objetivo foi outro: demonstrar a atuação dos indígenas de Ferradas como agentes de um processo histórico complexo e multifacetado, que thes impôs o ônus da conquista e muitas perdas e transformações sociais e culturais, mas certamente, também possibilidades de elaborar novas estratégias e de reconfigurar suas vidas dentro de um novo mundo.

Os aldeados de Ferradas atuaram na conformação da região sul da Bahia enquanto "região cacaueira", ao lado de outros sujeitos sociais, e a nova configuração econômica regional refletia os interesses políticos e sociais para a região. Considerar a proeminência do trabalho indígena nos serviços da estrada Ilhéus-Conquista, bem como no plantio da lavoura do cacau é imperioso para perceber o funcionamento das estratégias políticas e administrativas 
indigenistas, com vistas a garantir, através do processo de territorialização dos índios em aldeamentos, a exploração do trabalho das populações indígenas para o êxito do projeto imperial naquela parte do sul da Bahia, durante o século XIX. No entanto, é importante reconhecer a participação deles no processo de cultivo da lavoura do cacau, como mão de obra e como protagonistas de sua experiência histórica. 


\section{CAPÍTULO IV}




\section{OS FLUXOS DE ENCONTROS NA FRONTEIRA OITOCENTISTA EM CACHOEIRA DE ITABUNA}

Neste capítulo, o objetivo central é analisar as relações estabelecidas entre os diferentes atores no processo da colonização oitocentista em Ferradas e Cachoeira de Itabuna. Esse interesse tem a ver com a inquietação acerca de considerar como agiam aqueles sujeitos históricos e com a preocupação em não construir uma narrativa na qual os índios de Ferradas apareçam apenas como força de trabalho explorada. Temos clareza de que sua atuação como mão de obra diz muito da trajetória histórica deles. Mas considerá-los, apenas, como força de trabalho traz a incômoda sensação de que sua atuação é somente determinada pelos interesses do colonizador e que eles não vislumbravam interesses próprios. Em poucas palavras, neste capítulo nosso interesse é desconstruir a imagem de que os índios eram passivos trabalhadores do governo imperial.

Em Ferradas, tanto os Camacans e Guerens aldeados quanto os Camacans, Botocudos e Pataxós não aldeados, habitantes da região, participaram do processo da colonização de forma dinâmica. A ideia é apresentá-los e evidenciá-los se transformando na história da colonização sul baiana, durante o XIX. O processo deve ser observado enquanto uma teia, um emaranhado de conflitos e negociações, resultantes do encontro dos diferentes atores e grupos sociais naquela parte do sul da Bahia. 
Nesse sentido, são direcionadoras para o nosso trabalho as reflexões de John Monteiro e Celestino de Almeida, pois ambos os autores fazem uma leitura etno-histórica da realidade social, em que os índios em situação de contato são vistos construindo e reelaborando suas identidades.

Monteiro critica a "crônica da destruição dos índios", presente na historiografia. Ele toma como exemplo as reflexões de Florestan Fernandes, para quem os Tupinambás, em Pernambuco, teriam mantido sua coesão tribal através da migração, pois a prática migratória os livraria do impacto da colonização ${ }^{1}$. John Monteiro salienta, contudo, a emergência de outras leituras possíveis para pensar a atuação indígena no mundo colonial. Para Monteiro, o viés da etno-história permite interpretações nas quais o impacto colonial "não se resume apenas na dizimação de populações e na destruição de sociedades indígenas" ${ }^{2}$. Ao contrário disso, as novas leituras da relação entre populações indígenas e o mundo da colonização fazem emergir "diferentes formas de sociedades nativas após o contato ou a conquista". ${ }^{3}$

Nos processos de etnogênese - entendido como "as novas configurações étnicas e sociopolíticas" emergidas na situação do contato - se dá a possibilidade de construção de uma nova chave de compreensão das relações interétnicas, que envolve a "colaboração" e a negociação entre os atores no mundo da colonização. Como bem observa John Monteiro, para aquela realidade, "O envolvimento em guerras coloniais, em rivalidades intraeuropeias ou no crescente tráfico de cativos indígenas mostrou-se uma importante estratégia para vários grupos que buscaram res-

\footnotetext{
1 MONTEIRO, John Manuel. Op., cit., 2001, p. 55.

2 Idem, ibidem.

3 Idem, p. 62.
} 
guardar a sua autonomia, paradoxalmente através desta 'colaboração'"4.

O movimento de ressocialização das populações indígenas nas aldeias coloniais do Rio de Janeiro, estudado por Maria Regina Celestino de Almeida, exemplifica muito bem os resultados de uma historiografia envolvida em analisar os índios se transformando na história do pós-contato. Nos termos da autora, se metamorfoseando. Almeida ressalta que o ingresso nos aldeamentos coloniais impunha aos índios um processo de perdas e mudanças, que dizia respeito, entre outros aspectos, à terra, ao trabalho e às práticas culturais. Contudo, através da leitura etno-política, a autora concebe a atuação política dos índios das aldeias coloniais e os percebe reelaborando e construindo suas identidades. Nesse processo, a ideia de cultura não passa por algo dado a priori ou essencial. Ao contrário disso,

Tal processo, entendido à luz da noção de cultura dinâmica e histórica articulada com várias evidências empíricas, revela toda sua complexidade, permitindo perceber as mudanças não só como simples perdas culturais, mas também como propulsoras das novas possibilidades de os índios se adaptarem à colônia ${ }^{5}$.

As informações concernentes à documentação capuchinha produzida durante a atuação dos frades administradores dos aldeamentos do sul da Bahia são, em sua grande maioria, pouco elucidativas acerca dos vários aspectos abordados neste estudo, entre os quais o trabalho

4 MONTEIRO, John Manuel. Op., cit., 2001, p. 63.

5 ALMEIDA, Maria Regina Celestino de. Op., cit., 2013, p.147. 
indígena e as relações interétnicas. Contudo, a partir de uma leitura realizada a contrapelo dessa documentação, pudemos demonstrar a relação entre os índios de Ferradas e os produtores de cacau. Com a mesma metodologia de análise da documentação, pretendemos demonstrar, conforme a documentação nos permita, as relações étnicas estabelecidas intra e extra-aldeamento de Ferradas; e analisar e entender os processos de conflito, negociação e ressocialização dos índios aldeados e não aldeados daquela parte do sul da Bahia.

\subsection{Agenciamentos indígenas em Cachoeira de Itabuna: conflitos e negociações entre autoridades governa- mentais, religiosas, índios aldeados e não aldeados}

Pensar as reelaborações das identidades das populações indígenas como possibilidade de constituição étnica tem agenciado importantes reflexões no campo da história e da antropologia. Como parte dessas reflexões, Guillaume Boccara destaca o protagonismo dos Mapuches no processo de colonização chilena. $\mathrm{O}$ autor propõe pensar os efeitos do poder e dos mecanismos colonizadores sobre as populações indígenas e como estas reconfiguraram-se social e politicamente no "espaço fronteiriço"6. Boccara identifica, no processo de contato, a recriação identitária mapuche, ao longo dos séculos coloniais, pois estes se apropriaram de elementos oriundos da colonização e frequentemente recriaram suas identidades em novas formas de organização política, econômica e social. $\mathrm{O}$ autor supera a ideia

6 BOCCARA, Guillaume. "Poder colonial e etnicidade no Chile: territorialização e reestruturação entre os Mapuche da época colonial". Tempo: UFF, v. 12 , n. 23,2007 , p. 60. 
de duas alternativas únicas e dicotômicas para pensar a atuação mapuche no Chile colonial: a de povo guerreiro e irredutível opositor do poder colonial; ou a ideia de povos indígenas em vias de assimilação. Boccara observa a realidade do contato enquanto espaço de atuação e negociação entre "colonizadores" e "colonizados". Nas palavras do autor: "a identidade étnica mapuche emerge tanto como um produto da confrontação bélica, como da negociação política com os wingka, os não-mapuche" ${ }^{\prime 7}$.

A perspectiva etno-histórica apresentada por Almeida e Monteiro, de uma (re) criação identitária dos índios na realidade do contato colonial, bem como o caso dos mapuches, estudado por Boccara, nos impulsionam e possibilitam observar a documentação sobre o sul da Bahia de uma forma mais complexa. Desse ponto de vista, os aldeados de Ferradas são vistos agindo conflitivamente sobre os não aldeados no esforço de garantir a integridade do seu lugar de sobrevivência no mundo colonial; ao passo que aqueles não aldeados se utilizam das estratégias possíveis, e muitas vezes resistem e lutam fisicamente para garantir seus interesses, principalmente a permanência e sobrevivência em seus territórios. Mas como veremos adiante, esses mesmos índios "hostis", que em dados momentos tentavam barrar, em alguma medida, o avanço da colonização em Ferradas e Cachoeira de Itabuna, em outros estabeleciam práticas de negociação com os administradores imperiais.

Para os índios em situação de contato, mas não aldeados, hostilizar o espaço do aldeamento, situação que tentaremos demonstrar nos parágrafos seguintes, significava atingir e abalar, de alguma forma, as práticas do indigenismo naquela região. No entanto, nem

7 BOCCARA, Guillaume. Op., cit., p. 71. 
sempre o agenciamento indígena se dava pela estratégia da guerra nas relações entre não aldeados e colonizadores. Na região de Cachoeira de Itabuna e Ferradas, no processo da colonização, a estratégia da guerra foi tão utilizada quanto a estratégia da negociação entre os índios e o governo imperial da Província da Bahia, como demonstram, subsequentemente, alguns casos que analisaremos.

Ao longo de todo o século XIX, segundo a documentação analisada, os Pataxós e Potocudos figuraram como entrave ao projeto colonizador nos discursos gestados pelas autoridades governamentais e religiosas. Dentre as principais queixas dos capuchinhos e das autoridades governamentais locais, estão as que fazem referência aos ataques daquelas populações ao aldeamento São Pedro de Alcântara, aos aldeados, à estrada e aos fazendeiros locais, com uma maior predominância dos ataques sobre os índios aldeados em Ferradas.

TABELA 4 - Principais tipos de queixas acerca da ação dos índios não aldeados

\begin{tabular}{|l|l|}
\hline Descrição da ação desenvolvida & Ocorrências \\
\hline Ataques às roças e fazendas & 3 \\
\hline Ataques na estrada & 2 \\
\hline Ataques às plantações do aldeamento & 5 \\
\hline Roubo de ferramentas & 3 \\
\hline Ataques à povoação aldeada & 8 \\
\hline Total & 21 \\
\hline
\end{tabular}

Fonte: Tabela construída a partir das correspondências trocadas entre autoridades locais e provinciais, entre os anos 1840-1859: APEB; maços: 4612, 4613 e 2395-I; Arquivo Colonial e Provincial.

Nessa direção, são elucidativas da atuação dos índios não submetidos ao processo de territorialização, algumas correspondências trocadas entre as autoridades locais e 
provinciais, a exemplo do ofício encaminhado ao presidente da Província pelo juiz municipal de Ilhéus, Jerônimo dos Santos Quaresma, em 24 de novembro de 1840:

Levo a presença de V. Excia. O officio incluso que me dirigio Fr. Ludovico de Liorne Vigario da Freguesia de S. Pedro d'Alcantara, no qual faz aceitadas refleçoens a respeito dos ataques que tem sofrido do Gentio Barbaro; os habitantes daquella ditta povoação, havendo já commetido um assacigno do Indio José Victorio, estando este trabalhando em sua roça, alem de outras tentativas de mal fazer athé o ponto de entrarem na Povoação no sillencio da noite, e com violência tentarem arrombar as paredes das casas, e não conseguirão seo intento pelo alvoroço em que ficou toda a Povoação, refugiando-se todo Povo na Igreja, e disparando-se imenços tiros de espingardas $[\ldots]^{8}$.

Muito embora os aldeados e não aldeados daquela região mantivessem contato, visto que, como já explicitamos anteriormente, os aldeados de Ferradas mantinham um frequente trânsito na região, havia, naquela realidade de encontros, lugares sociais distintos entre os aldeados e os não aldeados, sobretudo entre Camacãs e Botocudos. Os primeiros correspondiam à maior parte da povoação do aldeamento, como as fontes por vezes testemunham; e os Botocudos se configuravam nos principais atores descritos pelas autoridades como dificultadores do processo colonizador.

Acontece em Ferradas o que Barth chamou de construção da fronteira étnica, que se faz com base no encontro e não na separação dos grupos e pessoas: "as distinções

8 APEB; Seção Arquivo Colonial e Provincial; Série Judiciário, maço 2395-1, ano 1840. 
de categorias étnicas não dependem de uma ausência de mobilidade, contato e informação" ${ }^{\prime \prime}$. Os grupos indígenas aldeados e não aldeados se encontravam em constante movimento e interação, no entanto, o encontro demarca fronteiras sociais entre aqueles grupos, situando-os em estado de conflito e oposição, porque também eram opostos os interesses que permeavam o encontro. Dessa forma, observamos, de um lado, índios não aldeados se utilizando do recurso disponível naquele momento: a força, no intuito de barrar, em alguma medida, o avanço de terras cultivadas pela agricultura que, por sua vez, lhes roubava a mobilidade num território que era seu legitimamente. De outro lado, os aldeados: eles assumiam a defesa daquele espaço territorializado ao qual, de forma reconfigurada, atribuíam um sentido de pertença.

Na perspectiva de Mary Louise Pratt, a fronteira não é o lugar que marca limites e divide territórios, pois se define como "zona de contato", constituído pela ação dos sujeitos; espaço que se define, redefine-se e está em constante movimento, conforme os conflitos estabelecidos entre os diferentes sujeitos históricos que se "encontram" naquela situação específica, "frequentemente dentro de relações radicalmente assimétricas de poder"10.

Em correspondência enviada por frei Ludovico ao juiz de paz de Ilhéus, no dia 13 de julho de 1840, ele volta ao assunto da violência e mantém o mesmo teor do ofício acima explicitado. Relata, de forma minuciosa, o assassinato de um dos aldeados, atribuído aos Botocudos habitantes daqueles territórios:

9 BARTH, Frederik. "Grupos étnicos e suas fronteiras". In: POUTIGNAT, Philippe; STREIFF, Jocelyne. Teoria da etnicidade: seguido de grupos étnicos e suas fronteiras. 2. ed., São Paulo: Ed. Unesp, 2011, p. 188.

10 PRATT, Mary Louise. Os olhos do império: relatos de viagem e transculturação. Bauru, São Paulo: EDUSC, 1999, p. 32. 
no dia três, visto que faltava hum Indio chamado Jozé Antonio e sabendo que no dia antecedente estava sozinho na sua roça, forão homens em procura delle, e acharão no mato, poucos passos distantes da mesma roça o seu corpo morto, transpassado de huma flecha, que do ombro esquerdo sahio a ponta fora do peito[... $]^{11}$.

O frade continua seu relato ao juiz de paz da vila de Ilhéus, descrevendo a forma como o corpo havia sido encontrado:

Tinha o rosto desfigurado por dous golpes de facão, que os Bárbaros lhes derão, hum entre os olhos e o nariz, e outro entre o nariz e a boca, profundos em modo que o queixo estava pendurado. Lhe tirarão fora o olho direito, lhe cortarão a pelle em roda do mesmo olho com toda a sobrancelha, tudo levarão consigo, e juntamente o facão, único ferro, que tinha o desgraçado defunto ${ }^{12}$.

Os índios aldeados em São Pedro de Alcântara eram, em sua maioria, Camacãs. Mas, na aldeia eles estavam misturados aos Guerens e também conviviam com os Pataxós e Botocudos nos espaços limítrofes do aldeamento. Pode-se explicar, em parte, a "violência" dos botocudos não aldeados sobre aqueles aldeados, considerando as observações de Maria Hilda Paraíso, para quem “os Kamacã-Mongoió não mantinham boas relações com os Pataxó e com os Botocudos que, ao que parece,

11 APEB; Seção Arquivo Colonial e Provincial; Série Judiciário; maço 2395-1; ano 1840 .

12 Idem. 
haviam se deslocado para seu habitat tradicional"13. A autora afirma ainda que "essa beligerância foi usada pelos conquistadores e colonos para transformá-los em combatentes dos outros grupos [nas regiões de] Nova Viçosa, Caravelas, Belmonte, Mucuri e ao longo do rio Pardo"14. No entanto, naquele espaço e naquele momento, o que estava em jogo não era, preponderantemente, a histórica rivalidade entre as etnias. Os botocudos pareciam calcular muito bem suas ações, pois o relato deixa claro que estavam em busca de ferro e o estado no qual o corpo foi encontrado sugere que aqueles homens, na realidade do contato, pretendiam demarcar os limites da ação colonizadora. Deixar o corpo de um dos aldeados mutilado sugere se tratar de um recado àquelas autoridades, portanto, uma ação politicamente calculada pelos indígenas categorizados de "Botocudos"15.

Outra estratégia dos Botocudos foi cercar o aldeamento e amedrontar a população aldeada, visto que, quatro dias após o "crime" ter sido cometido, mais precisamente "no dia sete antes da madrugada descobriose que huns delles estavão escondidos em hum quintal entre huns pez de café, o que se averiguou pelo rosto, que se vio quando o dia se for claro"16. Ludovico segue o seu

13 PARAÍSO, Maria Hilda Baqueiro. Op., cit., 1998, p. 279.

14 Idem, ibidem

15 Os botocudos são assim referidos: são aqueles que não aceitam o aldeamento e/ou dificultam a ação colonizadora, já quando aldeados, eles são os guerens. A documentação traz o termo Gueren apenas para designar os índios aldeados, transferidos do Almada para Ferradas, depois disso, os encontramos genericamente denominados de Botocudos em todos os registros documentais. Portanto, optamos por manter o termo botocudo no desenvolvimento do capítulo, pela impossibilidade de diferenciar os grupos indígenas designados sob este termo nas fontes.

16 APEB; Seção Arquivo Colonial e Provincial; Série Judiciário; maço 2395-1; ano 1840. 
relato sobre a morte do índio José Antônio, explicitando que "tirarão duas flechas ao fallecido, que huma se achou no corpo, e a outra no chão e pelo feitio dellas se conhece que os Bárbaros são Botocudos [...]. He claro que não são Patachós [...] pela certeza de que em vinte e quatro annos [...] nunca estes fizerão mal"17. Nesse episódio, foram os camacãs os principais atingidos, no processo de delimitação dos interesses entre aldeados e não aldeados. No entanto, nem sempre era esse o desfecho dos conflitos naquela "zona de contato".

Em correspondência de 25 de abril de 1842, o juiz municipal interino da Vila de Ilhéus, Antonio Lopes Benevides, assim se reportou à presidência da Província da Bahia:

17 Idem.

Tendo hua horda de índios selvagens hostilizando atraiçoando e progressivamente, há quazi cinco annos a povoação de S. Pedro de Alcantara, chove da estrada do Sertão para esta $\mathrm{V}^{\mathrm{a}}$ habitada por laboriozos índios Camacans, cathequizados, e dirigidos pelo muito Respeitável Pe Me Fr. Ludovico de Leorne, já vindo aquelles bárbaros cercar a Povoação a ponto vedarem aos ditos habitantes de hirem as suas rossas, que uzão roubar, já flechando-os e arrombando suas cazas do que tem rezultado mortes e ferimentos; accontece renovarem ultimamente seos insultos e crueldades, o que obrigou alguns dos mesmos Camacans a sahirem em seguimento, mas tendo sido descobertos no meio das matas impunhavão os bárbaros [as] flechas de que sem duvida aquelles seriam victimas se em defeza própria não lhes descarregassem as armas que levarão, 
occasionando a morte de quatro selvagens e apprehenção de cinco meninos, que não poderão fugir ${ }^{18}$.

Diferentemente do episódio anterior, nessa ocasião os camacãs aldeados, numa postura aparentemente defensiva, avançam sobre os Guerens e estando em posse de armas de fogo mais eficazes, do ponto de vista bélico, garantem um desfecho favorável aos seus interesses. Assim, obtiveram a manutenção da segurança do espaço de povoamento do aldeamento e garantiram a segurança em seus espaços de trabalho agrícola. Podemos observar que o aldeamento se caracterizava por ser um espaço reconfigurado pelos aldeados e de seu pertencimento a partir da experiência cotidiana da colonização. Nas palavras de Pratt, o processo de transculturação é um fenômeno típico da "zona de contato", e de acordo com a autora, "se os povos subjugados não podem controlar facilmente aquilo que emana da cultura dominante, eles efetivamente determinam, em graus variáveis, o que absorvem em sua própria cultura e no que o utilizam". ${ }^{19}$ Inferimos, portanto, que a defesa do aldeamento e de suas plantações em parte derivava do sentimento de pertença àquele mundo reconfigurado, animando as ações de defesa do espaço do aldeamento por parte dos aldeados de Ferradas. Obviamente essa afirmação deve ser relativizada, pois há outras chaves de compreensão possíveis para essa situação.

Havia naquela situação também o jogo de interesses dos não índios; ou seja, das autoridades governamentais e religiosas que exerceram um papel na tomada de decisão de

18 APEB; Seção Arquivo Colonial e Provincial; Série Judiciário; maço 2395-1; ano 1842.

19 PRATT, Mary Louise. Op., cit, p. 30-31. 
confronto. Essas autoridades forneciam armas aos índios, e se ocorria o deslocamento organizado do aldeamento para as matas, era porque os agentes da colonização consentiam e talvez incitassem. Como bem lembrou Paraíso, no processo da colonização a rivalidade beligerante entre Camacãs, Pataxós e Botocudos era utilizada e, dentre outras localidades afetadas, figura o rio Pardo, região de interesse dos colonos da região.

Notamos, contudo, que não era apenas ao longo do rio Pardo que os conflitos aconteciam, pois se estendiam também ao longo do rio Cachoeira ou Colônia. O agenciamento da guerra, nesse sentido, era bastante paradoxal. A guerra era empreendida tanto pelos índios não aldeados, para de alguma forma impedir o avanço da colonização sul baiana, quanto pelos aldeados, que ao mesmo tempo queriam defender o seu espaço de sobrevivência e segurança, bem como atuar apoiando os interesses da ação colonizadora.

É bem verdade que, no processo de expansão da colonização posta em prática no sul da Bahia oitocentista, os Pataxós e, sobretudo, os Botocudos foram violentamente perseguidos. A eles foram atribuídos discursos e práticas condizentes com a imagem de "natureza" de animalidade e fereza. Eles muitas vezes agiram e reagiram também com intensa violência, atacando e matando. Contudo, é igualmente verdadeiro que colonizadores e botocudos não eram, o tempo todo, incondicionais inimigos. Para além do discurso de fereza e demonização dos botocudos veiculado por autoridades governamentais e capuchinhos que atuavam na região à época - a realidade na situação de contato era bem outra.

Nesse sentido, apresentaremos, dentre as informações colhidas nos documentos oficiais trocados entre autoridades de Ilhéus e a capital da província, três casos 
nos quais Pataxós, Botocudos, colonos e autoridades locais atuaram naquela "zona de contato", negociando, de diferentes formas, os seus interesses e o estabelecimento de aldeamentos. Os não aldeados agiram não só pelo viés da guerra. Naquele mundo multifacetado, também agiram e reagiram ao processo de expansão territorial daquelas paragens de forma sutil, aceitando ou requerendo a vivência no mundo territorializado, mas estabeleciam, nesse processo, e conforme era possível, os seus próprios interesses.

$\mathrm{Na}$ interpretação das fontes analisadas, é interessante perceber como se davam, na prática, as relações entre os Botocudos e as autoridades governamentais e religiosas. Enquanto em alguns relatos oficiais os botocudos e, em menor grau, os Pataxós figuravam com destaque no quadro dos problemas e dificuldades que emperravam o avanço do processo colonizador no sul da Bahia, sendo descritos como inúteis ao projeto nacional, em outros os mesmos atores são mencionados como agentes que pareciam conscientemente atuar no jogo, sabendo perfeitamente a hora de resistir ou de se aproximar, e os momentos propícios para fazer alianças e negociar.

Como bem definiu Nacuzzi, os espaços de fronteira indicam "una zona permeable, porosa, en constante reacomodamiento" ${ }^{20}$. Por isso, formou-se, também no sul da Bahia, uma teia complexa de interesses dos grupos étnicos, que era instável, permitindo a construção de relações interétnicas conflitivas e negociadas.

Convém ressaltar, portanto, que o cenário de atuação dos pataxós e botocudos no sul da Bahia foi um campo

20 NACUZZI, Lidia R. Introdução. In: LUCAIOLI, Carina P.; NACUZZI, Lidia R. (Orgs.). Fronteras: Espacios de interacción en las tierras bajas del sur de América. Buenos Aires: Sociedad Argentina de Antropologia, 2010, p. 8. 
minado, durante todo o século XIX. Dessa forma, frisamos a observação de Vânia Moreira, acerca da atuação bélica contra os botocudos do Espírito Santo, como um processo que nos permite, em algum grau vislumbrar a realidade dos não aldeados naquela "situação de contato" no sul baiano. No contexto de deflagração de guerra justa contra os Botocudos da Capitania do Espírito Santo, processo no qual os indígenas sofreram as retaliações violentas de um forte aparato militar, Moreira observa que os Botocudos daquela Capitania "foram agentes bastante conscientes dos limites e das possibilidades existentes para eles no cenário da guerra ofensiva" ${ }^{21}$. Portanto, a negociação e construção de alianças faziam parte do cenário regional. Como a autora frisa, mesmo que isso significasse possibilidades "desiguais e transitórias" 22 entre índios e não índios, não era uma situação atípica para aqueles sujeitos num contexto de vulnerabilidade. Inferimos que também não o era para os Pataxós e Botocudos que atuavam no sul da Bahia durante os anos coloniais e imperiais.

Desse modo, propomos pensar a ação dos botocudos, conhecidos pelo seu suposto caráter irredutível ao processo colonial no sul da Bahia, para além da ideia engessada da existência de uma fronteira rígida entre colonizadores e índios. Sugerimos, portanto, pensar aquela realidade de contato como processo que funcionou numa mão dupla. Assim, por meio da negociação, podemos perceber as reconfigurações étnicas dos botocudos que, estrategicamente, se inseriam nos espaços territorializados.

21 MOREIRA, Vânia Maria Losada. "1808: a guerra contra os botocudos e a recomposição do império português nos trópicos". In: CARDOSO, José Luís; MONTEIRO, Nuno Gonçalo e SERRÃO, José Vicente (Orgs.). Portugal, Brasil e a Europa Napoleónica. Lisboa: ICS. Imprensa de Ciências Sociais, 2010b, p. 404.

22 Idem, p. 406. 
Assim como na realidade do Espírito Santo, observada por Vânia Moreira, os Botocudos e Pataxós do sul da Bahia agiam conscientes dos limites que lhes eram impostos. Eles sabiam a hora de resistir conflitivamente, mas também se adaptavam à condição colonial quando necessário. Eles sabiam que o poder de fogo do colonizador era mais poderoso do que as armas de que podiam dispor. Portanto, muitas vezes, a arma de que dispunham com mais eficiência e que eles usavam a seu favor, era mesmo a negociação.

A negociação estabelecida entre índios e não índios na situação de contato no sul da Bahia, em algumas ocasiões era aberta e bem demarcada; em outras, contudo, a negociação se dava de forma sutil, construída no intercâmbio fluído entre aqueles dois mundos. Nossa argumentação pode ser confirmada pelo testemunho da correspondência de Antônio Dias de Miranda à presidência da província, em 6 de dezembro de 1826:

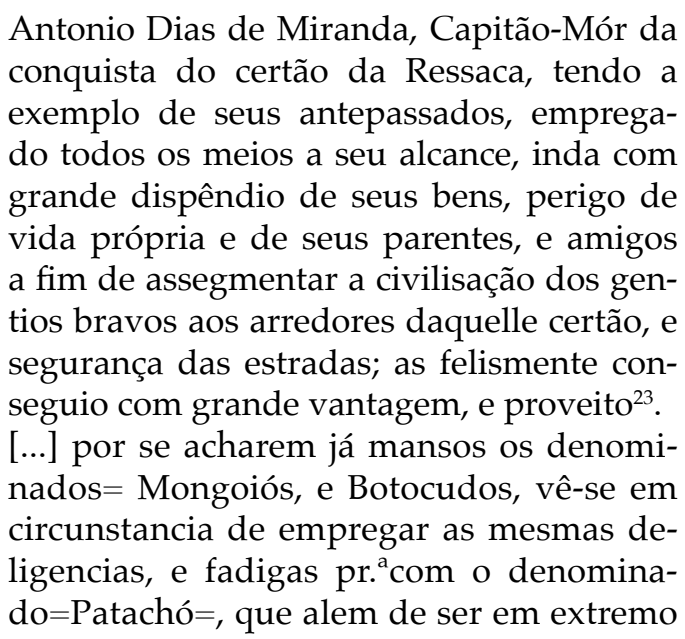

23 APEB; Seção Arquivo Colonial e Provincial; Série Agricultura; maço 4613; ano 1826. 
bravio, e numerozo, tem sempre vivido ceconcentrando nas montanhas mais [densas] esquivando-se de toda a comunicação, por isso, que elle mesmo de por si, vendo, que os indivíduos rezidentes debaixo do comando do supp.e, e mesmo este, tendo por muitas vezes precizão de passarem por suas habitações, sem o offender, temse aproximado aos recintos do dito certão da Ressaca, vindo até cassar junto as casas vizinhas das povoaçoens, sem offender a pessoa alguma, o que dá grandes indícios de se quererem domesticar ${ }^{24}$.

As famílias de Gonçalves da Costa e Antônio Dias de Miranda atuaram, historicamente, na região do rio Pardo na conquista dos sertões, no aldeamento dos camacãs ${ }^{25} \mathrm{e}$ combate violento aos Botocudos, como atesta Maria Hilda Paraíso $^{26}$. A região de Ilhéus e Conquista apresentava limites geográficos tênues, haja vista o esforço de ligação entre as referidas vilas pela abertura e conservação da estrada. Desse modo, a influência regional das famílias Costa/Miranda testemunha, mais uma vez, a relação estabelecida entre fazendeiros e autoridades locais e provinciais no sentido de garantir o bom êxito do projeto colonizador no sul da Bahia, durante o século XIX. Na referida correspondência, além de fazer um relato dos trabalhos prestados por sua família ao Governo Provincial naquela região, Dias de

24 APEB; Seção Arquivo Colonial e Provincial; Série Agricultura; maço 4613; ano 1826.

25 Segundo Maria Hilda Baqueiro Paraíso, 1998, p.279: Após tentativas frustradas de fazerem frente à conquista de suas terras, os Kamacã-Mongoió optaram por aceitar o aldeamento e as relações de dominação impostas pelos conquistadores, destacando-se, dentre eles, a família de João Gonçalves da Costa.

26 PARAÍSO, Maria Hilda Baqueiro. Op., cit., 1992, p. 416-417. 
Miranda aponta para a possibilidade do aldeamento de um grupo de Pataxós que habitava as redondezas ocupadas por moradores não índios.

No relato do capitão-mor Dias de Miranda, os camacãs (Mongoiós) e os Botocudos da região aparecem como povos já "mansos". Entretanto, outras tantas correspondências do mesmo período e de décadas posteriores retratam um cenário contrário a essa descrição de povos amansados, principalmente com referência aos Botocudos. Como demonstraremos em outro tópico, houve um demasiado esforço em caracterizá-los como "selvagens" que emperravam o processo colonizador no sul da Bahia. No entanto, na correspondência citada acima, eles aparecem ao lado dos Camacãs como mansos, e os Pataxós como extremamente bravios. Isso demonstra claramente as contradições dos discursos gestados na esfera do poder local, que tinham como objetivo justificar e legitimar os seus interesses econômicos, principalmente demonizando os Botocudos, quando thes convinha.

Podemos ainda observar as relações sociais, na zona de contato do sul da Bahia, entre índios e não índios. O relato de Miranda deixa em evidência o trânsito dos diferentes sujeitos naquela região. Nesse processo, podemos inferir que os Pataxós mantiveram os limites entre seu mundo e o mundo do colonizador enquanto foi possível. No entanto, com o avanço da colonização, os limites geográficos entre eles inevitavelmente se imbricavam e começou a ser conveniente, para os pataxós, se aproximarem, sobretudo para a garantia de sua sobrevivência, segurança e permanência em seus territórios.

Para os fazendeiros e autoridades locais, a "domesticação" e o aldeamento dos Pataxós significava assegurar o sucesso do projeto colonizador naquelas paragens. Nas palavras de Dias de Miranda, "domesticar" os Pata- 
xós tinha "[...] unicamente em vista alongar a civilização daqueles povos, e fazer prosperar a cultura, o sucego dos habitantes de seu districto, e mais vesinhos, e a segurança das estradas" 27 .

Os pataxós se aproximavam e permitiam que os não índios se aproximassem do seu território. Miranda ressalta que se fazia necessário oferecer "presentes" aos Pataxós a fim de persuadi-los. Em documento anexo à correspondência analisada, Dias de Miranda especifica os produtos necessários para oferecer aos pataxós:

"Relação de que se fazem precisas para offertar aos indígenas denominados Patachó a fim de os domesticar" 28

\begin{tabular}{|l|l|}
\hline Discriminação & Quantidade \\
\hline Machados & 40 \\
\hline Facoens ordinários & 40 \\
\hline Facas flamengas & 50 \\
\hline Carapuças vermelhas & 100 \\
\hline Missangas sortidas/massos & 24 \\
\hline $\begin{array}{l}\text { Pólvora, chumbo proporcionado } \\
\text { para segurança e deffeza das } \\
\text { pessaos que fazem precisas } \\
\text { empregar nesse serviço. }\end{array}$ & 1 barril \\
\hline $\begin{array}{l}\text { Dinheiro para pagamento dos } \\
\text { condutores das cargas, e mais } \\
\text { despezas, que ocorrerem até a } \\
\text { ultimação da empreza.c }\end{array}$ & 1000 réis \\
\hline
\end{tabular}

Marta Amoroso ressalta que, no Paraná, o Barão de Antonina elaborou e encaminhou ao governo o plano

27 PARAÍSO, Maria Hilda Baqueiro . Op., cit., 1992, p. 416-417.

28 APEB; Seção Arquivo Colonial e Provincial; Série Agricultura; maço 4613; ano 1826. 
direcionado à redução dos kaiowá. O plano seria colocado em prática pela atuação capuchinha, responsável pela catequese nos aldeamentos da região. O plano de Antonina consistia em "criar entre os índios as necessidades do homem civilizado, facilitando-lhes para isso os meios necessários"29. Amoroso sintetiza, em seu trabalho, que o plano de Antonina para as populações indígenas paranaenses visava provocar a "mudança de hábitos" dos índios, através da "conquista do paladar". Tratava-se de persuadi-los a ingressarem nos aldeamentos, oferecendo brindes, com o intuito de acostumá-los aos modos de vida do não índio e implantar neles a necessidade do consumo dos produtos ocidentais ${ }^{30}$. As práticas voltadas para a persuasão dos índios eram estratégias comuns às províncias e conhecidas desde os primórdios da colonização. Assim, Dias de Miranda, ligado aos interesses pecuários de Gonçalves da Costa no sertão da Ressaca, se utilizou da estratégia de sedução dos índios, a fim de aldeá-los.

Note-se, contudo, que dentre os gêneros a serem disponibilizados aos Pataxós a fim de atraí-los à condição aldeada aparece o "ferro", sobretudo ferramentas e armas como facas e machados. Seguindo a reflexão sugerida por Amoroso, tomada de empréstimo da etnologia, é importante realizar a leitura da "abertura para o outro", ou seja, pensar os possíveis interesses indígenas na situação de contato ${ }^{31}$. Marta Amoroso ressalta que os índios não se deixaram seduzir por qualquer coisa ou sem razão.

29 Antonina, apud AMOROSO, Marta Rosa. Catequese e evasão: Etnografia do aldeamento indígena São Pedro de Alcântara, Paraná (1855-1895). Tese de doutorado. Universidade de São Paulo, 1998, p. 66.

30 Idem, p. 64.

31 Idem, p.63 
Pois, da mesma forma que eles aceitavam os brindes no contato com o colonizador, eles igualmente se negavam a consumir os produtos ocidentais, em outras ocasiões, como forma de resistência cultural ${ }^{32}$. Nessa perspectiva, a estratégia colonizadora de sedução pode ser interpretada também considerando a forma como os índios vivenciaram essa realidade. Deve ser feita pelo viés da negociação no contexto do contato, processo no qual se deve fazer a leitura da abertura ao outro pelo caráter, prioritariamente, da apropriação e ressignificação.

A situação que envolve os Pataxós do sul da Bahia sugere que a separação entre os dois mundos, dos índios e não índios, era cada vez mais invisível. Tentava-se persuadir os Pataxós mediante oferta de "presentes" e, ao mesmo tempo, notamos que se eles ofereciam ferramentas era porque, em alguma medida, os Pataxós envolvidos naquela realidade se interessavam por tais objetos. Portanto, o intercâmbio entre índios e não índios acontecia também fora do perímetro do aldeamento, pois, antes mesmo de aldear-se, os Pataxós pareciam já comungar de outros saberes e do desejo de incrementar suas técnicas com as ferramentas dos colonizadores. Essa perspectiva era agenciada pelo estreitamento do convívio com o não índio e com os índios aldeados no mundo da colonização. Os espaços territoriais em comum se transformavam, portanto, em espaços de sociabilidades entre os diferentes sujeitos que ali se encontravam.

$\mathrm{O}$ segundo caso escolhido refere-se à negociação estabelecida entre Botocudos e o juiz municipal de órfãos de Ilhéus, Antônio d'Aguiar Silva, entre 1843 e 1845, sobre a instalação dos mesmos em um aldeamento.

32 Idem, p. 69. 
Diferentemente da sutileza apresentada na negociação envolvendo os Pataxós, nesse caso, o caráter de negociação entre autoridades e Botocudos fica bastante em evidência.

Em correspondência do dia 23 de maio de 1843, o juiz municipal de órfãos e delegado da Vila de Ilhéus, Antônio d'Aguiar Silva, se reportou ao Presidente da Província da Bahia, o desembargador Joaquim José Pinheiro de Vasconcellos, com o fim de relatar a negociação com um grupo de botocudos inas da região, acerca do seu estabelecimento em um aldeamento:

\begin{abstract}
A vinte e três do corrente veio ter commigo o Muito Reverendo Missionário Fr. Ludovico de Liorne anunciando-me que lhe tinhão apresentado dezesseis Botocudos das margens do Rio Pardo acompanhados de Victorio da Cunha Soares, por quem os tinha mandado convidar, e que exigião alguns prezentes, e dezejavão conhecer-me, por que lhes dissera que era necessário entender-se commigo para satisfaze- $\operatorname{los}^{33}$.
\end{abstract}

Por intermédio de Vitório da Cunha Soares, os Botocudos aceitam conversar com frei Ludovico. Contudo, dois aspectos desse fragmento são elucidativos acerca do desenrolar da negociação. Em primeiro lugar, ao que tudo indica, eles foram se encontrar com o frade de forma já organizada, pois aqueles dezesseis Botocudos estavam falando em nome de uma população maior; eram, portanto, seus representantes. Em segundo lugar, um ponto que é muito interessante: frei Ludovico aparece como figura-chave nesta negociação, confirmando mais uma vez a centralidade e importância do seu papel político, no que

33 APEB; Seção Arquivo Colonial e Provincial; Série Judiciário; maço 2395-I; ano 1843. 
envolvia a questão indígena na região sul da Bahia. Ludovico manda convidar os índios, negocia com eles e intermedia o desenrolar da negociação entre os índios e o juiz de órfãos de Ilhéus.

A narrativa documental segue nos dando pistas do interesse principal do governo local acerca da negociação com os referidos Botocudos. D'Aguiar Silva explicita ao Presidente Vasconcellos que,

[...] havendo a tribu denominada Noc-noc pelos Botocudos continuado suas incursões sobre as Ferradas e passando desta para baixo ameaçando já os Fazendeiros da Caxoeira de Itabuna, julguei que devia aproveitar os apresentados e seu guia para unidos com alguns Camacães sob a direção do Reverendo Missionário, que a isso com o seu ardente zelo verdadeiramente Evangélico promptamente se prestou, entrarem nas mattas e ver se podiam conseguir o aldeamento daquella tribu assim nocivo, ou pelo menos quando o recuzassem, aprehenderem alguns, e entrega-los ao dito Missionário para que attrahidos pela sua maneira de os tractar [cressem] no conhecimento de que não somos seus inimigos, antes dezejamos para elles as vantagens da vida social, e por este meio servimo-nos então dos aprehendidos para persuadi-los, e tomar amigos tão perigozos inimigos, ou quando menos evitar suas hostilidades ${ }^{34}$.

Nesse momento dos acontecimentos, a negociação acerca do aldeamento parecia exitosa, pois os inas já estavam mantendo relações com as autoridades locais e

34 APEB; Seção Arquivo Colonial e Provincial; Série Judiciário; maço 2395-I; ano 1843. 
prestando serviço ao governo imperial naquelas paragens antes mesmo da sua instalação em aldeamento, como deixa claro o fragmento acima. Juntamente com os camacãs de Ferradas, os 16 Botocudos inas ficaram incumbidos de persuadir ou aprisionar os botocudos da tribo noc-noc. Podemos, portanto, suscitar algumas reflexões importantes com relação ao fragmento destacado.

Mais uma vez, podemos perceber a complexidade das relações estabelecidas naquela "zona de contato". A realidade era fluida: à medida que um grupo de Botocudos era descrito pelo juiz de órfãos como "perigozos inimigos", com outro grupo construía-se aliança e negociava-se possibilidade de aldeamento. Igualmente delicada é a complexidade observada entre os diferentes grupos indígenas naquela situação específica. A relação é de conflito e de sobreposição de um grupo ao outro, processo intermediado pelos interesses que moviam autoridades de Ilhéus e botocudos em processo de negociação. Estava em jogo, naquele contexto, a manutenção da viabilidade do projeto colonizador em Cachoeira de Itabuna, visto que a maior preocupação das autoridades locais, acerca dos ataques da tribo noc-noc, dizia respeito à garantia de segurança aos fazendeiros de Cachoeira de Itabuna.

Outro aspecto muito revelador nesse fragmento, diz respeito aos direcionamentos da prática indigenista no sul da Bahia, em meados do Oitocentos, com relação aos índios resistentes ao processo colonizador, baseada na prática de apresamento, como evidencia a documentação. Fica nítido que a orientação das autoridades em relação à tribo noc-noc era o aprisionamento, caso se recusassem a aldear-se.

Ainda nos meandros da negociação, o juiz segue o seu relato, ao Presidente da Província, explicando que os índios, representados pelos 16 Botocudos, pretendiam aldear-se no retorno da ação contra os noc-noc: 
[...] Partirão hontem para esse feito muito satisfeitos comigo os apresentados, e o Missionário, promettendo-me aquelles que não offendirião aos Noc-noc e farião que viessem aldear-se, e que elles mesmos querião vir também para os governar, e que concluída a deligência a que hião, voltarião para thes dar vestidos para suas mulheres, e irião busca-los, e a seus parentes para cá. [...] Não menos [il.] a notícia do rezultado do que a aprovação de V. Ex $x^{a}$ sobre o que hei feito, e o que intenciono fazer se realizarem minhas esperanças, isto he, colloca-los no logar denominado Boqueirão mas se quizerem, visto já ter alli uma capella, posto que coberto de palha e algumas cazas ${ }^{35}$

A negociação estabelecida entre Botocudos e autoridades governamentais de Ilhéus se dá num jogo de interesses bem definidos. Como já mencionamos, as práticas violentas e coercitivas empregadas contra os botocudos desde a decretação da guerra justa, em início do século XIX, impunha a eles uma vivência instável nos territórios de expansão colonizadora. Garantir a própria sobrevivência e permanência em seus territórios muitas vezes passava pela disponibilidade da vivência nos aldeamentos. Inferimos, portanto, que os Botocudos da região de Cachoeira de Itabuna, de forma consciente e organizada, dispuseram-se a viver em aldeamentos como uma forma de resistir por outros meios: o da adaptação e ressignificação da própria vida. Vale lembrar que os Inas em negociação com Ludovico e o juiz de órfãos representam um grupo maior, vez que os 16 representavam os demais "parentes".

35 APEB; Seção Arquivo Colonial e Provincial; Série Judiciário; maço 2395-I; ano 1843. 
No dia 30 de junho de 1843, em documento anexo ao despacho da Tesouraria Provincial, o presidente da Província da Bahia Francisco José de Souza Soares d' Andréa, liberou verba para articular a ação planejada contra os noc-noc a pedido do juiz de órfãos de Ilhéus:

[...] inteirado de se lhe haverem apresentado, por intermédio do Missionário Fr. Ludovico de Leorne, 16 Botocudos das margens do Rio Pardo, e de, sob a direção deste mesmo Missionário empregados por Vosmicê sobre a tribu denominada Noc-noc que continua em suas incursões contra Ferradas, lhe authoriso, conforme pede, para as despesas que se fiserem indispensavelmente necessária com semelhante deligência ${ }^{36}$.

Em correspondência de 4 de fevereiro de 1845, o mesmo juiz de órfãos, Antônio d' Aguiar Silva, registra a informação de que depois de autorizado o estabelecimento do aldeamento pelo Presidente da Província, em junho de 1843 , se fazia necessário cumprir a exigência dos botocudos inas acerca da presença de um padre no estabelecimento:

[...] enviada que lhes fosse a noticia de que aqui se achava o desejado Padre, mandarão dizer-me que depois da Lua cheia seguinte verião recebe-lo. Com effeito apparecerão quarenta, e He inexplicável a satisfação que mostrarão quando lhes aprezentei o Missionário Fr. Francisco Antonio de Falerna, que não menos zelo mostra pela causa desses mizeráveis. Pedirão roupa para si, para os

36 APEB; Seção Arquivo Colonial e Provincial; Série Judiciário; maço 2395-I; ano 1843. 
outros que não vierão, e suas mulheres e filhos, e instrumentos agrários ${ }^{37}$.

Se, por um lado, o governo imperial manifestava interesse no aldeamento dos indígenas que ocupavam os espaços a serem colonizados, como fica evidente na fala do juiz de órfãos, "Ordenei-lhe que procurasse estabelece-los o mais próximo possível da estrada desta Villa para o interior ${ }^{\prime \prime 3}$, por outro lado, os índios muitas vezes também escolhiam viver a realidade do aldeamento, mas não como objetos passivos de tal processo. As fontes testemunham que eles estavam açodados pelas guerras e perseguições, mas que procuravam manter o comando das negociações em curso e de forma organizada, ou seja: primeiramente, foram eles que manifestaram desejo de aldear-se; em segundo lugar, aparentemente, eles escolheram o lugar da instalação da aldeia, pois o juiz deixa claro que os instalaria no lugar chamado "Boqueirão", caso eles quisessem; em terceiro, determinaram quando iriam buscar o missionário para o estabelecimento do aldeamento; por último, partiu dos próprios índios o interesse em ter um missionário.

As estratégias dos Botocudos do sul da Bahia não eram novas ou estranhas no mundo colonial. John Monteiro observa que, no período colonial, momento de implantação das "diversas formas de integração do índio na sociedade escravista" ${ }^{\prime 3}$, as populações indígenas sem condição de reproduzir seu modo de viver das aldeias,

37 APEB; Seção Arquivo Colonial e Provincial; Série Judiciário; maço 2395-I; ano 1845.

38 APEB; Seção Arquivo Colonial e Provincial; Série Judiciário; maço 2395-I; ano 1845 .

39 MONTERIO, John Manuel. Op., cit., 1994, p. 170. 
procuraram construir seus próprios espaços dentro da nova realidade que se lhes apresentava na sociedade colonial. "Esta busca, embora produzisse resultados no mais das vezes ambíguos, manifestava-se tanto na luta cotidiana pela sobrevivência quanto nas múltiplas formas de resistir". ${ }^{40}$

Também à luz das reflexões de Regina Celestino de Almeida sobre as aldeias coloniais do Rio de Janeiro, na realidade dos estudos que envolvem os índios em situação de contato, no século XIX, a autora observa que eles muitas vezes se interessavam pelas mudanças e, em outras, se aproveitavam da condição de índios aldeados para garantir seus próprios interesses. Essa estratégia não passava apenas pela prática de requerimento de direitos à terra através de processos jurídicos, estratégia demonstrada em muitos estudos indígenas atuais. Podemos observar, no sul da Bahia, os Botocudos se valendo estrategicamente da vivência nos aldeamentos como forma de manter sua permanência em seus territórios. Requeriam o aldeamento e aceitavam a condição de índios aldeados para permanecer em suas terras, dali podendo entrar e sair e continuar a ter acesso a um perímetro maior do que os limites dos aldeamentos. ${ }^{41}$ Não é possível dizer que os índios que se submetiam ao aldeamento construíram uma identidade de aldeados, contudo, podemos aventar que, para os Botocudos requerentes, ter um religioso no aldeamento significava, em algum grau, manter a legitimidade

40 Idem, ibidem.

41 LISBOA, Balthazar da Silva. Op., cit., p. 207-209: Carta de Ludovico a Lisboa, de 1819, na qual ele relata que os índios de Ferradas, depois de aldeados, entravam e saiam do "sítio"; em outra carta - nota: 96 do capítulo II-, de 1829, o mesmo Ludovico deixa claro que os índios mantinham um trânsito entre o aldeamento e outras aldeias mais ou menos independente. 
do novo lugar social no qual estavam inseridos, pois como acompanhamos ao longo deste estudo, a figura dos frades capuchinhos era direcionadora e central no projeto de colonização, naquela região.

Dentre os três casos de negociação entre índios e autoridades com o propósito de estabelecimento de aldeamentos na região sul da Bahia, o último diz respeito à solicitação de outro grupo de Botocudos, representado pelos índios Narciso, Miguel e José Antônio:

Exige V. Ex ${ }^{a}$ por despacho de 17 de Agosto ultimo nos documentos que devolvo, que informe acerca de hum requerimento de Indios Botocudos, que se dizem moradores nas margens do Rio Pardo e adjacências, pretender hum terreno entre o Riacho Catulé e de S. Pedro, afim de formarem ahi hua aldêa, que poderá prestar aos navegantes do Rio Pardo sustento e auxilio de braços. ${ }^{42}$

De imediato, temos a contrapartida oferecida pelos botocudos para o cumprimento de sua solicitação ao governo provincial. Os índios solicitaram aldear-se e para tanto, ofereciam sua mão de obra para o importante trabalho de navegação do rio Pardo. A transformação do rio Pardo em rio navegável e em via de comunicação e transporte exigia a existência de "canoeiros", pois, sem isso, o acesso às diferentes localidades da região se tornaria quase impossível. Essa demanda poderia ser satisfeita pelos índios, que sabiam cumpri-la com propriedade e habilidade. Eles demonstram ter consciência da importância de sua mão de obra naquele ramo de trabalho e se valem disso para assegurar o seu interesse.

42 APEB; Seção Arquivo Colonial e Provincial; Série Judiciário/juízes de Tl héus; maço 4611; 26 de novembro de 1849. 
Em 26 de novembro de 1849, Manoel Inácio de Lima, Diretor Geral dos Indios da Província da Bahia, em resposta ao ofício a ele dirigido pelo presidente da província esclarece:

[...] Tive portanto de dirigir-me a Frei Ludovico, que mandou-me o officio junto datado de 28 de setembro deste corrente anno, dizendo ser estes três Botocudos os autores do requerimento conhecidos e por V. Ex $x^{a}$. recomendados ao Doutor Villaça Juiz Municipal de Canavieiras para os coadjuvar na abertura do Sítio, ou lugar da dita aldêa, o qual He sadio, fértil, e está ainda totalmente diserto; que esses Indios tem de regressar a esta Cidade, e então d'elles saber-se-há do numero d'individuos e as demais informações, que thes tinha exigido para satisfazer a requisição de V. $\mathrm{Ex}^{\mathrm{a}}{ }^{4}{ }^{3}$

Com o seguimento das negociações, em novembro do mesmo ano, Manoel Inácio de Lima reporta à presidência da província as deliberações acerca da instauração da nova aldeia:

[...] os três Botocudos Narciso, Miguel e José Antônio com seu guia Manoel Lima, os quaes devendo ser acompanhados de hua ordem positiva do Governo, afim de que lá chegados, mandem sua gente para Canavieiras em procura de Frei Ludovico, que lá os espera; e hum rol de objectos necessários para a nova aldeia do Espírito Santo. São alguns instrumentos agrários, e roupas para quarenta cazaes. Permitta V. Exa ${ }^{\mathrm{a}}$, que note a omissão de algumas terras e de outros instrumentos

43 APEB; Seção Arquivo Colonial e Provincial; Série Judiciário/juízes de Ilhéus; maço 4611; 26 de novembro de 1849. 
muito necessários para as construções indispensáveis para a fundação de hua aldêa, como se obterão taboas feitas a machado, enxada e fouces? ${ }^{44}$.

Na sequência de nossa análise acerca da negociação entre os três Botocudos e as autoridades governamentais, Inácio de Lima conclui que lhe cabia tão somente deliberar as questões práticas e oficiais para o cumprimento da determinação presidencial, em atendimento ao requerimento dos botocudos, visto que os seus preparativos já haviam sido acertados sob o aval do Presidente da Província:

\begin{abstract}
[...] A vista do que acabo de expor a V. Ex ${ }^{\mathrm{a}}$., os preparativos para essa nova Aldêa, como já tivessem tido começo de algua sorte, debaixo da protecção e influência de V. Ex ${ }^{a}$., restame tão somente conforme o decreto ${ }^{\circ} 426$, que me serve de regimento, officiar a [sua] excelentíssima [recomendação] pedindo-lhe quanto antes hum Missionário para a nova aldêa, o qual receberá desta Directoria Geral as instruções necessárias, para o que pretendo ouvir hua outra vez a Frei Ludovico ${ }^{45}$.
\end{abstract}

Esse caso é bastante elucidativo acerca do direcionamento das negociações entre índios e autoridades. As autoridades, aliás, eram muitas e variadas, pois envolvia a presidência e o diretor geral dos índios, o juiz municipal e frei Ludovico. Fica em evidência, mais uma vez, a atuação de frei Ludovico como importante interlocutor dos interesses regionais. Como bem demonstra a fala de Manoel Inácio de Lima, frei Ludovico participou da negociação,

44 Idem

45 APEB; Seção Arquivo Colonial e Provincial; Série Judiciário/juízes de Ilhéus; maço 4611; 26 de novembro de 1849. 
ao menos indiretamente; além disso, partiriam dele as instruções para o trabalho do missionário designado para a nova aldeia.

Também fica em evidência, na documentação, que, primeiramente, os índios demonstram interesse de aldear-se e oferecem sua mão de obra para o serviço de canoagem; contudo, o mais interessante é que, ao que tudo indica, eles viajam até o presidente da Província e negociam diretamente com ele, pois o Diretor Geral dos Índios esclarece que os Botocudos requerentes eram os "conhecidos" pelo presidente da província e "recomendados" por ele ao juiz de Canavieiras. Isso é muito significativo no que toca às agências indígenas no processo da colonização sul baiana, pois diante de uma hierarquia estabelecida para tratar dos assuntos indigenistas com o governo da Província, os índios se interessam em negociar diretamente com a autoridade máxima, o Presidente provincial.

A negociação estabelecida nessa ocasião demonstra, mais uma vez, que os índios não eram vítimas passivas e ingênuas no processo de expansão territorial da região sul baiana, tampouco os botocudos atuavam unicamente como inimigos inconciliáveis do governo e moradores locais, como pretendeu demonstrar o discurso oficial sobre a "fereza" deles, forjado por parte da documentação compulsada. Era porque apostavam também no jogo da negociação, que se tornava possível o aldeamento dos índios.

\subsection{O que era ser índio aldeado no Sul da Bahia? \\ Ressocialização dos grupos étnicos no processo de territorialização oitocentista}

A maior parte da população aldeada em São Pedro de Alcântara era da etnia Camacã, tendo em vista que as 
correspondências trocadas entre as autoridades locais e provinciais fazem maior referência a ela. "Era um grupo Macro-jê (...). Seu território tradicional localizava-se entre os rios de Contas e Pardo, (...) limitava-se a leste com o dos Pataxós, na altura do córrego da Piabanha, afluente da margem esquerda do rio Colônia ou Cachoeira". ${ }^{46}$

Freitas e Paraíso observam que os aldeados de Ferradas eram do grupo "Kamacã-Mongoió". Na Capitania e posterior comarca de Ilhéus, como frisa Paraíso, os Camacãs "são referidos por Kamacã-Mongoió, ao norte do rio Pardo; Kamacã Menian e Menian na área do Pardo, do Colônia e do Mucuri, e por Caranins em Nova Viçosa e Caravelas" ${ }^{\prime 4}$. Ainda segundo os autores, não se pode afirmar que as diversas denominações camacãs se devia às subdivisões dos grupos, ou ainda, se eram atribuídas pelos próprios Camacãs ou por terceiros.

Vale lembrar que um dos principais direcionamentos advindos da política colonial e que era colocado em prática também pela política indigenista imperial, nesse momento, era o incentivo à mistura de diferentes grupos e etnias indígenas nos aldeamentos de catequese. E desde pelo menos o Diretório Pombalino, também se incentivava a mistura de índios e não índios, pois "procurando assimilar definitivamente os índios aldeados, incentivava a presença de brancos nas aldeias" ${ }^{\prime 4}$. Com relação ao Aldeamento São Pedro de Alcântara, a documentação oficial não testemunha o convívio direto de índios e não

46 PARAÍSO, Maria Hilda Baqueiro. Op., cit, 1998, p. 278.

47 Idem, p. 279.

48 PERRONE-MOISÉS, Beatriz. "Indios livres e índios escravos: Os princípios da legislação do período colonial (séculos XVI a XVIII)". In: CUNHA, Manuela Carneiro da. (Org.). História dos índios no Brasil. São Paulo: Companhia das Letras, FAPESP, 1992, p. 119. 
índios neste espaço, muito embora possamos observar essa possibilidade a partir da análise do Quadro das aldeias dos índios da Província da Bahia, de 1861 (Anexo 2), em que são discriminadas as situações das terras dos aldeamentos que não eram cultivadas por índios, sugerindo, pois, que elas estavam sendo cultivadas também por colonos daquele local.

Como demonstramos no capítulo anterior, eram muito próximas e fluídas as relações estabelecidas entre aldeados e colonos na região do Aldeamento São Pedro de Alcântara. A documentação analisada permite demonstrar que a intenção oficial era a promoção da mistura de índios e não índios. Contudo, na realidade do Aldeamento São Pedro de Alcântara, os indígenas, através de suas agências, talvez tenham se mantido à parte da convivência com o branco no interior do aldeamento.

A prática advinda do Diretório Pombalino previa a mistura de índios e não índios nos aldeamentos. Mas, naqueles espaços, também coabitavam frequentemente grupos indígenas etnicamente distintos, como bem lembra Perrone Moisés ${ }^{49}$. O mesmo acontecia em São Pedro de Alcântara, no século XIX, onde coabitavam distintas e rivais etnias indígenas.

No caso do Aldeamento São Pedro de Alcântara, na ocasião de sua fundação, coabitavam Camacãs e Guerens, esses últimos denominados também de Botocudos, que eram grupos historicamente rivais dos Camacãs naquelas paragens do sul da $\mathrm{Bahia}^{50}$. Por conseguinte, nos anos iniciais do funcionamento do aldeamento, podemos perceber alguns limites demarcados na convivência entre aqueles

49 PERRONE-MOISÉS, Beatriz. Op., cit., p. 119.

50 PARAÍSO, Maria Hilda Baqueiro. Op., cit., 1998, p. 279. 
diferentes grupos étnicos. Como observa Barth, as relações interétnicas "pressupõem uma estrutura da interação como essa: um conjunto de prescrições dirigindo as situações de contato e [...] um conjunto de proscrições sobre as situações sociais que impeçam a interação interétnica em outros setores". ${ }^{51}$

Desse modo, foram estabelecidas fronteiras étnicas e espaciais entre Camacãs e Guerens no espaço territorializado do Aldeamento, haja vista a descrição de frei Ludovico acerca dos aspectos da moradia daqueles grupos "Os índios do Almada são em numero de treze famílias, que formão treze casas arruadas defronte do Templo [...]; atraz da Igreja estão as casas dos Camacães em quadrado, que formão huma bonita praça" ${ }^{\prime 52}$.

Muito embora em São Pedro de Alcântara coabitassem Camacãs e guerens, além dos Pataxós que viviam no perímetro do aldeamento, sob a ótica das autoridades locais eles passavam a formar uma única massa, a dos aldeados em processo de civilização. E acima das divisões étnicas, linguísticas e culturais que existiam entre eles, em algumas ocasiões, também os percebemos manifestar-se segundo o lugar no qual estavam socialmente inseridos. Mostra disso é o fragmento documental no qual os índios de Ferradas, se valendo da situação de aldeados, solicitam a presença de um missionário no aldeamento. Assim, a mistura, aparentemente etnocida, se analisada pelo viés da etnogênese, permite perceber o processo não como perda de identidade étnica, mas como um processo de construção de pertencimento a outro lugar e papel social, através da agência indígena.

51 BARTH, Frederik. Op., cit., p. 197.

52 LISBOA, Balthazar da Silva. Op., cit., p. 207-209. 
Ao mesmo tempo em que os aldeados de Ferradas eram vistos como uma massa de índios úteis aos propósitos governamentais locais, eles mesmos, paulatinamente, se apropriavam dessa condição para seus próprios fins. Interessavam-se em manter o aldeamento em segurança, como já explicitado, bem como em aprender as técnicas e os usos da terra para fins da agricultura. Os registros documentais nos dão indícios de que, na nova configuração a que foram submetidos, à sua maneira, os aldeados tentavam se inserir e aproveitar as possibilidades apresentadas no espaço territorializado.

Os aldeados tinham noção da importância do seu trabalho na agricultura, bem como em trabalhos especializados, como a fabricação de canoas e a navegação e desobstrução dos rios. Aquelas pessoas "em situação de aldeamento", ao contrário de simples subjugadas aos propósitos do Estado, se deixavam "subjugar" e se apropriavam do mundo do aldeamento. Acerca disso, o documento dirigido à presidência da Província pelo Diretor da Aldeia de Ferradas, Egídio Luís de Sá, em 21 de maio de 1859, nos oportuniza analisar a atuação dos índios segundo essa perspectiva:

[...] Alguns desses homens, Exm. . Snr, possuídos já de algum cabedal de conhecimentos religiosos, e ja pelo amor ao trabalho, descerão a esta Villa reclamando [il.] de um padre $\mathrm{q}^{\prime}$ the fosse servir alli de bem reger suas acçõs, e lhes ministrasse os sacramentos q' offerece a Igreja a seus fieis, e dirigindo-se ao Doutor Juis municipal desta Villa, consta-nos $\mathrm{q}^{\prime}$ esse promethera a tal respeito representar a V. Excia. dando no q' podia para ora satisfaser-lhes com cuja resposta voltarão elles tristes, e bastante descontentes ${ }^{53}$.

53 APEB; Seção: Arquivo Colonial e Provincial; Série: Agricultura; maço 4612; ano 1859. 
Num primeiro olhar, o fato de os indígenas de Ferradas se deslocarem de sua aldeia até a Vila de Ilhéus, para reivindicar um missionário, pode parecer uma necessidade tutelar, característica dos moldes de convivência nos quais estavam inseridos. No entanto, se analisarmos essa situação à luz do contexto de insegurança da vida nos sertões, onde os aldeamentos se configuravam em espaços que asseguravam a sobrevivência e como um espaço que, de certa forma, permitia aos índios assegurar o domínio parcial sobre seus territórios, podemos então entender a postura dos aldeados como uma estratégica tentativa de acomodação ao mundo da colonização.

Ao se deslocarem até a Vila de Ilhéus para solicitar do juiz municipal providências acerca da entrada de um novo padre missionário na aldeia, para lhes garantir os sacramentos, os aldeados de Ferradas mais do que aceitarem o lugar de aldeados, se apropriaram do espaço do aldeamento como seu espaço de pertença, e talvez desejassem e escolhessem também assumir a identidade de cristãos. Também os Inas que negociavam a instalação de um aldeamento com o juiz de órfãos de Ilhéus, Antônio de Aguiar Silva, cujo desenrolar já acompanhamos anteriormente, solicitaram um padre e foram recebê-lo. Isso significa que eles adotaram a condição de aldeados catecúmenos e um novo lugar no mundo local; e isso estava relacionado a dois objetivos, pelo menos: garantir as suas terras e sua sobrevivência coletiva.

No estudo de Izabel Missagia de Mattos sobre os botocudos da Província de Minas Gerais, a autora observa "a incorporação do Outro" pelos atores pesquisados enquanto estratégia etnopolítica ${ }^{54}$. Ainda de acordo com a autora,

54 MATTOS, Izabel Missagia de. Civilização e revolta: os Botocudos e a catequese na Província de Minas. Bauru, SP: EDUSC, 2004, p. 26. 
trata-se de uma experiência "capaz de orientar os grupos indígenas impactados pela expansão da fronteira extrativista e agrícola". ${ }^{55}$ Nos termos de Mattos, podemos inferir a incorporação do "Outro" da fronteira sul baiana pelos camacãs, através dos símbolos religiosos (os sacramentos) do catolicismo, enquanto "estratégia etnopolítica" dos homens e mulheres que reconfiguram suas vidas a partir das experiências vivenciadas naquela situação específica.

Na realidade do contato, no sul da Bahia, durante a segunda metade do século XIX, ser índio aldeado significava, paradoxalmente, ter proteção e terra, mas também trabalhar ao lado dos colonos na positivação dos seus interesses, disponibilizando mão de obra na lavoura, pacificando a região e trabalhando ao lado dos religiosos e demais colonizadores na atração dos índios ainda não submetidos ao processo da territorialização. Quando os botocudos, os atores dos casos anteriormente analisados, negociavam a criação de aldeamentos na região, eles visavam o acesso à terra e também a segurança de viver no espaço do aldeamento; em contrapartida, estavam conscientes de que deveriam ficar a serviço do governo e dos locais. Enfim, eles fizeram guerra pelos seus espaços territoriais; sofreram coerções violentas; e, ao final, negociaram a própria rendição, conseguindo terra e oferecendo como moeda de troca o trabalho que mais poderia interessar a eles e aos colonizadores.

Vale ressaltar que, nas experiências diárias entre aldeados e missionários, não foram apenas os índios que mudaram e assumiram novas perspectivas diante do novo mundo. Os missionários, representantes dos interesses imperiais e dos particulares da região, mais próximos dos

55 MATTOS, Izabel Missagia de. Op., cit., p. 26. 
índios pela sua convivência diária, também se transformaram nesse processo. Eles se viram obrigados a mudar de estratégia, reconhecendo muitas vezes a incapacidade de gerir exclusivamente nos seus moldes a vida dos aldeados.

Acerca disto, recuperemos uma das correspondências de Ludovico de Livorno dirigida a Balthazar da Silva Lisboa. Nela, frei Ludovico se refere aos indígenas de Ferradas em tom de desapontamento e, ao mesmo tempo, reconhecendo a incapacidade de governar a vida dos índios estritamente nos moldes pensados pela política do aldeamento de catequese:

[...] Respeito á educação moral e civil destes Indios não posso estender minhas vistas acima da capacidade delles, e fóra dos limites destes bosques, pois a experiência me tem feito ver, que fora daqui ficão cheios de vícios, voltão vadios e mestres de impiedade: tal He a escola do século, bem diverso da pratica de como se considera na theoria ${ }^{56}$.

Dessa forma, não apenas os índios aldeados se transformaram; também aqueles que estavam ocupados da tarefa e dos mecanismos de aldeá-los foram transformados na zona de contato. Tal perspectiva permite pensar a realidade do contato de forma mais complexa e interativa entre as partes envolvidas. Além disso, os aldeados de Ferradas aparecem reconstruindo o seu mundo à maneira das expectativas de colonos e missionários, mas também frustrando-os na medida em que faziam escolhas próprias e punham limites quanto à governança de suas vidas.

56 LISBOA, Balthazar da Silva. Op., cit., p. 216-217. 


\subsection{Que "feras" são essas?}

No início desse capítulo, observamos os Botocudos protagonizarem negociações com o poder governamental. Nesse último tópico, propomos analisar o conjunto das correspondências selecionadas para este estudo, nas quais, diferentemente das relações de negociação entre colonizadores e índios não aldeados, os Botocudos são apresentados como implacáveis inimigos e dificultadores do projeto colonizador na região. No sul da Bahia, portanto, "feras" eram os índios que não aceitavam submeter-se ao aldeamento. Nessa perspectiva, nos ocuparemos, neste tópico do capítulo, de suscitar algumas reflexões possíveis acerca da construção de uma ideia de fereza e animalidade, por parte do governo de Ilhéus, sobre os Pataxós e Botocudos que resistiam ao processo colonizador. As falas do governo local tinham por objetivo conseguir do governo provincial, a disponibilização de verbas, armamentos, munições e ferramentas para a agricultura, dentre outros interesses. Como veremos adiante, quase todos os relatos de ataques dos botocudos, muitos de maneira expressivamente exagerada, eram acompanhados do pedido de verba ou qualquer outra requisição por parte do governo local ao governo provincial.

Como bem lembra Manuela Carneiro da Cunha, ainda no século XVI declaração papal reconhecia a humanidade dos índios. Mas de forma Paradoxal, no século XIX são levantados os questionamentos sobre a humanidade ou animalidade deles ${ }^{57}$. Portanto, nos anos imperiais, "a humanidade dos índios era afirmada oficialmente, mas privadamente ou para uso interno no país, no entanto, a

57 CUNHA, Manuela Carneiro da. Op., cit., p. 134. 
ideia da bestialidade, da fereza, em suma, da animalidade dos índios, era comumente expressa" 58 .

A demonização dos Botocudos justificava mais investimentos do governo imperial na política de aldeamento na primeira metade do século XIX, visto que, naquele momento, os interesses expansionistas recaíam sobre os territórios historicamente habitados por populações resistentes ao processo colonizador. Ao mesmo tempo, demonizar os denominados Botocudos fazia parte do substrato ideológico do desmonte de uma política colonial que historicamente havia garantido os direitos de vassalagem aos índios. Ainda que na prática permanecessem as diferenças entre índios e não índios, como bem lembra Lopes, ${ }^{59}$ legalmente os índios eram vassalos ou potenciais vassalos da Coroa. Demonizá-los significava, dentre outras estratégias, legitimar a perseguição e expulsão dos Botocudos dos espaços territoriais de interesse da expansão agrícola.

Para Izabel Missagia de Matos, que se debruçou sobre as práticas indigenistas empenhadas em promover a mestiçagem dos aldeados do Itambacuri, na Província de Minas Gerais, através da metodologia da catequese capuchinha observada para aquela região, "[a] exclusão do indígena 'puro' - no limite, incorrigível - fez parte da lógica colonizadora e civilizatória que pautou a catequese do Itambacuri".$^{60}$ Em outras palavras, em fins do século XIX, diferentemente dos aldeados em vias de mistura e civilização, os Botocudos da Província mineira que emperravam o processo civilizador deveriam ser extirpados. A experiência indigenista do Itambacuri de

\footnotetext{
58 Idem, ibidem.

59 LOPES, Fátima Martins. Op., cit., p. 395.

60 MATTOS, Izabel Missagia de. Op., cit., p. 401.
} 
exclusão do Botocudo, o "incorrigível", ilumina nossa argumentação acerca de um discurso de demonização dos Botocudos do sul da Província da Bahia.

Convém ressaltar que, mesmo a partir do Decreto 426, a dualidade filantropia e intolerância marcarão as discussões políticas e as práticas implementadas sobre as populações indígenas do Brasil, ambas características presentes nas ideias e práticas acerca da política indigenista do século XIX. Filantropia e intolerância existiam simultaneamente em diferentes espaços socais e políticos, pois, como observou John Monteiro, "encontrava-se filantropos no sertão, como Marlière, por exemplo, do mesmo modo que se encontrava patrocinadores de chacinas nas cidades" ${ }^{61}$ Nessa direção, bem serve de exemplo a radical posição "antiindígena" de Francisco Adolpho de Varnhagen, no quarto ponto do seu Discurso Preliminar:

\begin{abstract}
[...] Assim longe de condemnarmos que se fizesse uso da coacção pela força para civilizar os nossos Indios, estamos persuadidos que não era possível haver emprego outro meio; e que delle havemos ter que lançar mão nós mesmos, em proveito do paiz, que augmentará seus braços uteis, em favor da dignidade humana, que se vexa em presença de tanta degradaçãao ${ }^{62}$.
\end{abstract}

Ao que parece, a ideia de civilizar o índio paradoxalmente abrigava alternativas opostas. Aldear e "civilizar" eram a tônica oficial. Mas, na prática, quando essa opção se colocava difícil de realizar, a opção pela expulsão e

61 MONTEIRO, John Manuel. Op., cit., 2001, p. 142.

62 VARNHAGEN, Francisco Adolpho. "Discurso Preliminar: os índios perante a nacionalidade brazileira". In: Os Índios e a ordem Imperial. MOREIRA NETO, Carlos Araújo. Brasília: Funai, 2005 [1852], p. 326. 
perseguição se tornaram alternativas corriqueiras. Para John Monteiro, "civilizar ou exterminar, estas alternativas que remontavam aos primórdios da colonização, moviam as discussões nos sertões e nas cidades". ${ }^{63}$

A Carta Régia de 1798, que abolia o Diretório Pombalino, dentre outras medidas, decretava o fim da guerra ofensiva aos grupos indígenas resistentes ao processo de colonização dos sertões; mas, ao mesmo tempo, admitia a guerra defensiva, que terminava por significar o mesmo processo $^{64}$. Na prática, continuavam legítimos os mecanismos de violência e perseguição contra os índios denominados botocudos. Para Moreira Neto, um dos principais motivos para as decretações de "guerra justa" às populações indígenas, em início do século XIX, estava relacionado à transferência da corte portuguesa para o Brasil, em 1808, e, consequentemente, ao interesse expansionista de tornar colonizáveis os territórios historicamente pertencentes às populações resistentes a tal processo.

No bojo de reflexão acerca da transferência do poder real para o Brasil e de intensificação das ações "anti-indígenas", Cunha destaca a figura de dom João VI, cuja atuação desencadeou, a partir de1808, violentas guerras ofensivas contra os indígenas denominados botocudos, com o fim de colonizar o Vale do Rio Doce ${ }^{65}$. Vânia Moreira observou que, na Capitania do Espírito Santo, a resistência de populações indígenas, que perdurou por todo o século XIX, era o grande problema a ser enfrentado pelos "luso-brasileiros". ${ }^{66}$ Ainda destacou que, até a década de 1840, os ataques à Província do Espírito Santo,

63 MONTEIRO, John Manuel. Op., cit., 2001, p. 143.

64 MOREIRA NETO, Carlos de Araújo. Op., cit., p. 234.

65 CUNHA, Manuela Carneiro da. Op., cit., p. 136.

66 MOREIRA, Vânia Maria Losada. Op., cit., 2010b, p. 399. 
pelos Botocudos se intensificaram, o que tornou as ações governamentais contra eles ainda mais coercitivas e violentas. Nesse processo, a Carta Régia de 1808 assegurou incentivos financeiros aos militares "que evitassem mortes de portugueses e destruição de suas plantações em seus respectivos distritos e que conseguissem aprisionar e matar maior número de índios". ${ }^{67} \mathrm{~A}$ observação de Moreira demonstra a intensidade da atuação beligerante colonizadora sobre os denominados Botocudos naquela região. A mesma postura governamental aparecerá por toda parte, no Império, onde os Botocudos estivessem.

Na Bahia e em Minas, segundo Paraíso, "três Cartas Régias definiram a ação local contra os Botocudos: as de 13/5, 5/11 e 12/12 de 1808". ${ }^{68}$ Para a autora o estopim da guerra no sul da Bahia se deu pelo enfrentamento dos índios à família de Gonçalves da Costa, que atuava historicamente na ocupação territorial da região. Como apontamos anteriormente, a família de Gonçalves da Costa tinha interesses econômicos na região da Vila de Conquista e desejava manter um corredor de comércio entre a região e Minas, visto que havia implantado a pecuária na região do rio Pardo e precisava tornar transitável e seguro aquele território ${ }^{69}$.

Missagia de Mattos salienta que o etnônimo Botocudo carrega, subjacentemente, um sentido pejorativo, expresso nos relatos das experiências do colonizador com essas populações em Minas, ao longo do XIX. Contudo, a autora mantém o termo Botocudo em seu estudo de maneira metodologicamente "deformada" do sentido primeiro,

\footnotetext{
67 Idem, p. 400.

68 PARAÍSO, Maria Hilda Baqueiro. Op., cit., 1992, p. 416.

69 Idem, p.416-417
} 
como ela própria esclarece. De forma contrária ao sentido depreciativo empregado para os atores que faziam uso dos Botoques nos lábios, Mattos emprega o uso do termo Botocudo "para identificar os atores confusamente dispersos nas fontes e enfatiza a coerência de seu protagonismo no interior dos processos históricos" ${ }^{\prime 70}$. Ela frisa, ainda, que a utilização do termo Botocudo muitas vezes se apresenta mais adequado se empregado no plural, no sentido de dar visibilidade a sua pluralidade étnica.

Também em nosso estudo sobre o sul da Bahia, poucas fontes dão visibilidade aos subgrupos que estavam sob a abrangência do termo Botocudo. No conjunto da documentação, esses atores aparecem descritos enquanto "selvagens", "bárbaros" ou "gentios". À vista disso, assim como Mattos, entendemos que a utilização do termo no plural, no sentido de dar visibilidade àqueles atores homogeneamente descritos como uma massa de "feras" indóceis, demonizada no processo de avanço da colonização dos sertões do sul da Província da Bahia, se apresenta como escolha mais adequada para dar conta de sua atuação histórica naquele processo.

No período colonial, Marcelo Dias observa que havia certo alarme das autoridades e moradores da capitania de Ilhéus com relação às proporções dos relatos sobre os ataques dos Aimorés, que, por sua vez, tinham como objetivo justificar as entradas contra os mesmos ${ }^{71}$. A ideia de Juciene Ricarte Apolinário sobre os akroás da Capitania do Piauí nos anos coloniais é consonante a observação de Dias para os Aimorés da Capitania de Ilhéus. Apolinário observa que, no processo colonizador

70 MATTOS, Izabel Missagia de. Op., cit., p. 30.

71 DIAS, Marcelo Henrique. Op., cit., 2007b, p. 190. 
do sul do Piauí, no século XVIII, a construção da ideia de hostilidade dos Akroás legitimava a ação "etnocida" colonizadora. Nas palavras da autora, "Os ataques dos povos indígenas narrados nos documentos coloniais mitificavam os Akroá e constituíam um poder discursivo que justificava as ações violentas dos conquistadores". ${ }^{72}$

No século XIX, a descrição de animalidade e consequente demonização dos índios resistentes à colonização permanecerá nos relatos das correspondências entre autoridades locais e provinciais. Contudo, as intenções que guardavam as justificativas das autoridades governamentais de Ilhéus, nos idos do XIX, eram outras. No sul da Bahia, os Pataxós e Botocudos figuravam nos registros documentais como os entraves ao sucesso colonizador. Nota-se isso nas narrativas sobre os ataques dos Pataxós e Botocudos ao Aldeamento de Ferradas, à estrada, aos colonos e às fazendas. Em todos os documentos em que aparecem essas narrativas, via de regra aparece também a solicitação de armas, munição, ferramentas e verbas aos cofres provinciais. Nesse sentido, diferentemente da realidade observada para o período anterior, estudado por Dias e Apolinário, nos anos imperiais a estratégia central não era apenas legitimar entradas contra as populações resistentes à colonização, pois visava-se, igualmente, conseguir, do governo central da Bahia, benesses materiais e econômicas.

Concernente à ideia de demonização dos Botocudos por parte das autoridades da Vila de Ilhéus, bem como

72 APOLINÁRIO, Juciene Ricarte. “Os Akroá nos sertões coloniais: uma história de guerra e 'paz' entre currais e descobertos auríferos". In: OLIVEIRA, João Pacheco de (Org.). A presença indígena no Nordeste: processos de territorialização, modos de reconhecimento e regimes de memória. Rio de Janeiro: Contra capa, 2011, p. 150. 
pelos missionários capuchinhos que atuavam nos aldeamentos do sul da Bahia, destacamos o conteúdo de um requerimento de Frei Ludovico ao juiz de paz da vila de Ilhéus, datado de 13 de julho de 1840.

Frei Ludovico requeria do juiz da Vila de Ilhéus providências militares contra os Botocudos diante de um caso de "assassinato" de um dos aldeados, que o frade afirmava ter sido cometido por eles. O relato sugeria uma cena de horror e demonstrava que o crime havia sido cometido com requintes de barbaridade. Na sequência, o frade descrevia a realidade de medo em que, segundo ele, se encontravam os aldeados de Ferradas:

[...] Na mesma hora pouco antes do meio dia os seis homens que forão, trouxerão o corpo a esta Povoação, que toda ficou em susto, e terror [...]. Todos estes Indios assustados por se verem expostos a huma nova traição de hum inimigo escondido se refugiarão nas suas cazas, vigiando de dia e de noite, por explorar o numero, a qualidade e o intento dos agressores, em lugar como este descampado. ${ }^{73}$

O relato de Ludovico demonstra o caráter de demonização dos Botocudos, descritos frequentemente como seres desumanos, hostis e ferozes. No relato daquele episódio, Frei Ludovico destaca que pela maneira de fabricação das flechas se sabia que os bárbaros eram botocudos, e menciona que muito provavelmente aqueles botocudos estavam ali "tangidos, e enfurecidos da peleja de Mucuri e Rio Do$\mathrm{ce}^{\prime \prime 74}$. Nesse contexto, retomamos a realidade beligerante na

73 APEB; Seção Colonial e Provincial; Série Judiciário; maço 2395-1; ano 1840.

74 Idem 
qual se encontravam os índios das vizinhas Províncias de Minas e do Espírito Santo; como já mencionado, maiores medidas militares contra os Botocudos do Espírito Santo foram implementadas dentre 1800 e $1840^{75}$. Desse modo, era provável, portanto, que os denominados Botocudos migrassem para o sul da Bahia, fugidos ou expulsos dos seus territórios no rio Doce. Maria Rosário de Carvalho, em estudo sobre os índios da Vila do Prado, extremo sul da Bahia, menciona a migração dos indígenas afugentados dos arredores de Minas para o extremo sul baiano, e diz que sua simples presença na região era motivo de interpelação violenta e beligerante ${ }^{76}$.

No relato sobre o ataque à roça e sobre a morte do aldeado José Antonio, o frade ressalta a certeza de que os "bárbaros" eram os "Botocudos". Acrescentava que, certamente, não eram os "Patachós tanto pelo feitio das flechas, como pela certeza de que em vinte e quatro annos com suas frequentes chegadas nunca estes fizerão mal"77. Ludovico conclui o seu relato sobre o episódio ocorrido em São Pedro de Alcântara, solicitando ao juiz de paz da vila de Ilhéus, que fossem tomadas as devidas providência: "que seja servido nos limites de sua jurisdição expedir só sem demora huma força provisória, se não offensiva, pelo menos deffensiva". ${ }^{78}$

A solicitação de Ludovico de Livorno de medidas ofensivas ou defensivas contra os Botocudos que ameaçavam

75 MOREIRA, Vânia Maria Losada. Op., cit, 2010b, p. 400.

76 CARVALHO, Maria Rosário de. "Indios do sul e extremo sul baianos: reprodução demográfica e relações interétnicas". In: OLIVEIRA, João Pacheco de (Org.). A presença indígena no Nordeste: processos de territorialização, modos de reconhecimento e regimes de memória. Rio de Janeiro: Contra Capa, 2011, p. 367.

77 APEB; Seção Colonial e Provincial; Série Judiciário; maço 2395-I; ano 1840. 78 Idem. 
Ferradas corrobora as práticas vigentes em nível nacional e demonstra o mecanismo de perseguição às populações indígenas do sul da Bahia. Como bem observou John Monteiro, "atrair ou repelir, civilizar ou exterminar [...]. A noção de civilização, ao que parece, abrigava os dois extremos" ${ }^{\prime 79}{ }^{\text {É conso- }}$ nante com essa observação de Monteiro a fala do alferes comandante do quartel da Cachoeirinha, José Atanásio Ribeiro, a um juiz da Vila de Ilhéus: "Ill.m Snr. não há outro algum remédio mais do que a força das marchas sobre esses ferozes sedentos do sangue humano". 80

Em correspondência ao presidente da província, em 25 de abril de 1842, o juiz municipal interino da vila de Ilhéus, Antônio Lopes Benevides, relata ao governo provincial um conflito entre Botocudos e Camacãs do Aldeamento de Ferradas, quando os Botocudos foram feridos, afugentados e quatro morreram na referida contenda. $\mathrm{O}$ juiz se reporta ao governo provincial preocupado com um possível ataque de vingança dos botocudos:

(...) Este acontecimento, que teve logar no dia 16 do corrente promete as mais serias consequências, pois que não havendo aquelles selvagens recebido já mais a menor vendicta dos Camacans, apezar de insolente e barbaramente provocados não cessavão de repetir as suas depredações, agora estimulados por certo procurarão vingar-se em occazião opportuna da perda que soffrerão, e accometerial raivozamente essa indefeza Povoação se promptamente lhe não fosse mandado socorro; o qual tendo-me sido requizitado pelo mencionado Pe. Missionário Fr. Ludovico que teme seja perdido o fructo

79 MONTEIRO, John Manuel. Op., cit., 2001, p. 143.

80 APEB; Seção Colonial e Provincial; Série Judiciário; maço 2396; ano 1840. 
de seos trabalhos apostólicos com aniquilação de hua tão interessante Povoação ${ }^{81}$.

Muito embora os Botocudos estivessem em situação de desvantagem diante dos Camacãs, que estavam munidos de armas de fogo, belicamente mais poderosas que as flechas dos Botocudos, o relato do juiz municipal faz ecoar certo alarme na descrição das consequências a que a população estaria submetida, caso não se garantisse a ela o socorro do governo central da Bahia.

O seu relato guardava um tom de comoção; e parece interessar-se, o presidente provincial, em garantir a requisição feita na sequência:

Tomei por tanto a deliberação d'accordo com o respectivo juiz de Paz e o Tenente Coronel da G. N. de enviar para ali hum destacamento de 16 G. 2 Cabos e huma corneta commandados por hum Sargento [...]. He o destacamento composto de gente pobre que por isso não quis prestar-se a esta deligencia sem a solene promessa de serem abonados soldos equivalentes as privações que vão soffrer os auzentes de suas formas que sustentão com seo trabalho mecânico, e rural, ou separados dos commodos da vida social a se exporem nas matas as flexas dos selvagens ${ }^{82}$.

Portanto, Benevides comunica ao governo provincial a decisão de enviar para o aldeamento reforço militar para combater os Botocudos num suposto ataque de vingança. Para tanto, o juiz municipal conclui a correspondência requerendo verba para o sustento dos homens destinados

81 APEB; Seção Colonial e Provincial; Série Judiciário; maço 2395-I; ano 1842.

82 APEB; Seção Colonial e Provincial; Série Judiciário; maço 2395-I; ano $1842 .$. 
para manter a segurança de Ferradas. Ao final do documento, Benevides argumenta que, pela urgência do caso, ele havia conseguido empréstimos de dinheiro, armas e munição de cidadãos locais e solicita ao governo provincial que aprovasse suas decisões. De forma implícita, solicitava, ao presidente da Província, ressarcimento da verba. Deixa em evidência "que [garantia o empréstimo] em nome de Vossa Excelência" ${ }^{13}$. Ele justificava as medidas tomadas, pois desejava a manutenção da segurança da povoação de São Pedro de Alcântara, bem como da vila de Ilhéus contra os ataques dos Botocudos.

Em 24 de novembro de 1840, Jerônimo dos Santos Quaresma, juiz municipal de Ilhéus, dirigiu-se ao presidente da Província informando acerca de outro ataque dos Botocudos ao Aldeamento de Ferradas. Aventa a possibilidade levantada por Frei Ludovico, de substituir a solicitação feita ao governo provincial de reforço militar para o aldeamento, pela disponibilização de armas e munições. Jerônimo Quaresma justifica que,

(...) por ser aquella ditta Povoação cituada no meio de uma imença matta, a margem do Rio Caxoeira, que há de distar desta Villa, pelo menos oito a nove legoas, em cujas mattas, essas praças que o Exmo. Governo ordenou ali destacarem, nenhum conhecimento della podem ter, e por isso se deve aprovar o plano dado pelo Religioso Vigário em seo Officio, de serem providos aquelles Povoadores, com armamento, e suficientemente munidos de pólvora, e chumbo groço, visto haver na Povoação gente suficiente de defender-se, logo que sejão armados, se V. Exa. ouver, por bem assim o determinar,

83 APEB; Seção Colonial e Provincial; Série Judiciário; maço 2395-I; ano 1842. 
e servir-se mandar suspender a ordem de vir o destacamento; ficará a Povoação mais defendida, e será para a Thesouraria menos dispendiozo, do que o suprimento do ditto destacamento ${ }^{84}$.

O documento se inicia relatando a morte do aldeado José Vitório e o estado de pavor da população de Ferradas perante os ataques dos botocudos. Diante do exposto, seria mais razoável optar pela disponibilização do imediato reforço militar. Contudo, o frade revoga a solicitação anterior e envia outro ofício solicitando armas e munição, postura bem contraditória em face da urgência que, segundo ele, pedia a situação. Ludovico pede a revogação de uma solicitação já liberada pelo governo central, para pedir armamento e munição, uma nova solicitação, que demandaria mais tempo para a sua disponibilização.

No último relato selecionado, os indígenas classificados como "selvagens" eram os pataxós. A correspondência contendo o relato do missionário Vicente Maria de Ascoli, então diretor de São Pedro de Alcântara, foi enviada pelo diretor geral dos índios ao presidente da província, Alvaro Tibeiro de Moncorvo, no dia 10 de dezembro de 1855:

O missionário director da aldeia de S. Pedro de Alcantara, do termo dos Ilheos Fr Vicente M. ${ }^{a}$ d'Ascoles participa-me em data de 3 do corrente que os selvagens Pataxós tem atacado sua aldeia de Camacans desde junho (...) de sorte q. já tem avido conflitos de q. sahirão feridos dos Camacans, sem saber o [il.] missionário o que aconteceo aos selvagens. Informa q. entre o rio Salgado e a

84 APEB; Seção Colonial e Provincial; Série Judiciário; maço 2395-I; ano 1840. 
[Estiva] na estrada da conquista achou-se a mão de 1 homem cortada, o q. elle atribui ser dos Pataxós. Pede providencias, e ora não me ocorra outra se não authorisar V. Ex. ${ }^{a}$ pelo cofre geral e verba de estradas a abertura da de Ilheos para Minas a cargo do dous missionários Fr Vicente $\mathrm{M}^{\mathrm{a}}{ }^{\mathrm{d}} \mathrm{d}^{\prime}$ Ascoles e Fr. Rainero de Ovada, a fim de attrahir [moradas] q. afugentem os índios bravos em quanto não podem ser allienados pelos missionários ${ }^{85}$.

No fragmento acima citado, o conflito entre camacãs aldeados e os Pataxós que habitavam aquelas redondezas foi utilizado como argumento para a solicitação de verba existente nos cofres provinciais, destinadas às obras da estrada. $\mathrm{O}$ relato desse conflito, assim como o dos demais, valoriza o medo e a desordem para, ao que tudo indica, persuadir as autoridades provinciais. Ao supervalorizarem as situações de violência e ao demonizarem os Pataxós e os Botocudos, tratam os conflitos como artifício para solicitar recursos materiais e financeiros ao governo provincial.

Marcelo Henrique Dias observa, em seus estudos sobre a Capitania de Ilhéus, a construção do "mito da devastação da Capitania pelos aimorés". Dias ressalta que a historiografia regional reduziu as populações indígenas ao papel de entraves ao bom êxito da colonização, responsabilizando-as pela decadência de Ilhéus no século XIX ${ }^{86}$, e frisa que "uma investigação mais atenta nos testemunhos de época revela um certo grau de alarmismo nos discursos de então, os quais, muitas vezes, não correspondiam à real

85 APEB; Seção Colonial e Provincial; Série Agricultura; maço 4613; ano 1855.

86 DIAS, Marcelo Henrique. Op., cit., 2007b, p. 188-189. 
dimensão das ocorrências [que] (...), normalmente antecediam a organização de entradas" ${ }^{\prime 77}$.

O mesmo tom de alarmismo observado por Dias reaparece em relação aos Pataxós e aos Botocudos, durante o século XIX, nos registros das autoridades governamentais e dos missionários da então Comarca de Ilhéus. Parecia imperioso e interessante, para o governo local, construir uma imagem demonizada dos Botocudos, e da região como estando continuamente atacada por seres que beiravam a animalidade. Essa estratégia visava claramente dois objetivos: legitimar a perseguição, a expulsão e até mesmo o extermínio dos grupos indígenas que não aceitavam a vivência nos aldeamentos; e alimentar a imagem de fereza dos botocudos e Pataxós, para obter o apoio financeiro do governo provincial.

87 Idem, p. 190. 


\section{CAPÍTULOV}




\section{A "EXTINÇÁO" DO ALDEAMENTO SÁO PEDRO DE ALCÂNTARA: NAÇÃO, POLÍTICA INDIGENISTA E INVISIBILIZAÇÁO DOS ÍNDIOS NA ORDEM IMPERIAL}

No último capítulo deste estudo, pretendemos refletir sobre a política indigenista do século XIX, especialmente a paulatina extinção dos aldeamentos com fins de inserir os índios em a nação brasileira, concomitantemente à ideia de sua extinção social e cultural. A produção historiográfica que discute a legislação indigenista oitocentista afirma a transitoriedade da utilização da mão de obra indígena, a exemplo de Carneiro da Cunha, com quem já dialogamos neste estudo. Além disso, a historiografia indígena tem discutido a transitoriedade dos aldeamentos oitocentistas, a exemplo de Celestino de Almeida. Os aspectos suscitados por Cunha e Almeida permitem pensar como podemos situar Ferradas no processo da colonização sul baiana, durante o século XIX.

Finalizando o estudo, nos ocuparemos em observar a política e o discurso indigenistas de "extinção" do Aldeamento São Pedro de Alcântara. Os índios de Ferradas, tão atuantes no processo de ocupação e exploração territorial na região sul da Bahia, de repente desaparecem da documentação e isso merece ser abordado com mais cautela, pois os indícios documentais nos levam a perceber a criação 
da Colônia Nacional Agrícola Cachoeira sobre o aldeamento de Ferradas. Tudo leva a crer que os índios permaneceram no novo estabelecimento de colonização e, neste capítulo, ensaiaremos algumas aproximações entre os distintos projetos de aldeamento de catequese e de colônias nacionais agrícolas. Ao que tudo indica, houve um premeditado esforço de invisibilização da presença indígena na região do "antigo" estabelecimento de catequese, no momento em que começou a implantação da colônia agrícola.

\subsection{Algumas reflexões sobre os direcionamentos acerca da inserção indígena na construção do Estado-nação}

Como bem frisa Cunha, o século XIX é heterogêneo, e com o mesmo caráter de heterogeneidade é que se apresentam os direcionamentos da política indigenista daquele período. O Oitocentos foi marcado pela transferência do modelo político colonial para o imperial; pela construção do Estado-nação e pelas discussões, nos espaços de debate, sobre os rumos que a nova Nação teria que seguir. Sendo assim, o que emerge do debate acerca da construção do Estado nacional e as demandas políticas a ele relacionadas,

[...] é o processo que expunha termos como
'colonização', 'catequese', 'população', tra-
balho livre', 'imigração europeia, 'terras
devolutas' e 'civilização dos índios' como
ideias postas em cena, adquirindo, cada
um, significados correlatos ao dos demais,
cujas interpretações, hierarquias ou priori-
dades, de acordo com os projetos expostos,
tornavam-se uma construção à parte desse
mesmo percurso'.

1 KODAMA, Kaori. Op., cit., p. 212. 
As discussões em torno de uma legislação para os índios em meados do século XIX estavam muito influenciadas pelo Diretório Pombalino, como já pontuamos em outros momentos do trabalho. Um dos aspectos persistentes da política indigenista pós-pombalina é a insistência na "secularização", onde a questão central da catequese dá lugar ao problema da civilização. Essa questão foi abordada por Manuela Carneiro da Cunha, que escreveu: "uma retórica mais secular de 'civilização' vinha se agregando à de catequização. E 'civilizar' era submeter às leis e obrigar ao trabalho" ${ }^{2}$.

Com o advento da Independência, em 1822, emergiu simultaneamente a necessidade de criação de um projeto de Nação que conferisse, ao Brasil, um lugar apropriado no cenário mundial do início do Oitocentos. O momento foi marcado, internacionalmente, por transformações do sistema capitalista que, aos poucos, deixava de se basear numa economia comercial e avançava para o patamar industrial. Esse processo gerou modificações importantes no conjunto das relações socioeconômicas de vários países, trazendo à tona novas práticas para a obtenção de lucros. Nesse contexto, o Estado Imperial brasileiro, recémformado, empreenderá esforços para a afirmação do seu projeto de Nação, fundamentando-se nas ideias modernas de civilização ${ }^{3}$.

Integrou esse debate, no Oitocentos, José Bonifácio, indivíduo letrado, defensor dos ideais iluministas e político

2 CUNHA, Manuela Carneiro da. Op., cit., p. 142.

3 Sobre o conceito de Civilização, ver ELIAS, Nobert. O processo civilizador: Uma história dos costumes. Volume 1. Rio de Janeiro: Ed. Jorge Zahar, 1994. p. 51-52. O autor analisa as mudanças de costumes operadas no ocidente a partir do estabelecimento e da consolidação das monarquias absolutistas na Europa. Verificou que, na França, tal processo se consolidou com a gradativa adoção dos comportamentos aristocráticos pela burguesia em ascensão. 
experiente, que era um dos principais expoentes nas discussões voltadas para a construção do Estado-nação. Bonifácio foi um dos intelectuais que procurou enfrentar e colocar na pauta das discussões políticas e legislativas, daquele momento, os delicados problemas que o Brasil teria de enfrentar para alcançar o lugar de nação moderna e civilizada. Atuou ativamente no processo de construção da Nação brasileira, por meio dos seus projetos enviados à Assembleia Legislativa, projetos "que se destinavam, por diferentes vertentes, a levar o Brasil ao progresso enquanto nação" ${ }^{4}$. Nessa perspectiva, Bonifácio abordou a questão da escravidão como um entrave à modernização, bem como destacou a questão indígena, defendendo que a braveza dos índios ao processo civilizatório se devia à maneira como os brancos lidavam com as circunstâncias que, nessa direção, envolviam os povos indígenas. As ideias de Bonifácio reforçaram, posteriormente, as concepções de Gonçalves de Magalhães que, por sua vez, fez frente às proposições de Varnhagen quanto à estratégia de integração indígena ao projeto nacional.

Paralelo à construção da nação brasileira, fez-se necessário, portanto, pensar o lugar que as populações indígenas do império deveriam ocupar na história nacional. Nessa direção, o estudo de Kaori Kodama aponta que, ao lado do termo nação, designando o estado nacional brasileiro, em voga, nos anos imperiais, também existia o termo nações, no plural, forjado pelos integrantes do Instituto Histórico e Geográfico Brasileiro para designar as populações indígenas do território do Brasil.

Kodama, com base no trabalho de Mary Karasch, que analisou a designação do termo nação como referência

4 MACHADO, Marina Monteiro. A trajetória da destruição. Índios e terras no Império do Brasil. Dissertação de mestrado. UFF, Niterói, 2006, p. 45. 
aos escravos africanos que viviam na cidade do Rio de Janeiro, na primeira metade do século XIX, ressalta que a designação de nações, tanto para os indígenas quanto para os africanos, não tinha necessariamente relação com suas identidades culturais ${ }^{5}$. Ela acentua que o termo era recorrentemente empregado nos textos publicados na revista do IHGB para qualificar grupos indígenas; observa, também, que nos estudos publicados pelos intelectuais do Instituto, era frequente o intercâmbio entre os termos nação e raça ${ }^{6}$. Segundo Kodama, o termo nação, colocado no plural, referia-se a um sentido cunhado desde a Idade Média e que se preservou até o século XIX. Designava a diferenciação entre o "populus Dei ou povo de Deus" daqueles que eram destituídos de um "estatuto político e civil", ou seja, enquanto "povo" era um conceito jurídicopolítico, o termo "nação" designava um conceito biológico, o que o aproximava da noção de raça ${ }^{7}$.

Nesse processo, no qual, de alguma maneira, se deveria forjar a participação das "nações" indígenas na nação brasileira, Kodama destaca a atuação dos estudos etnográficos empreendida pelo IHGB. Como parte desse processo, FreireAlemão propunha, em 1847, o mapeamento das populações indígenas do território brasileiro; a proposta deveria ser encaminhada aos presidentes das províncias ${ }^{8}$. Se para Freire Alemão era importante mapear as "nações" indígenas do Império, para Cunha Barbosa, sob a ótica de uma ação civilizadora destinada aos índios dos "sertões", "[o] mapeamento deveria igualmente reduzir as nações a um entendimento escalonado, hierarquizado.

5 KODAMA, Kaori. Op., cit., p. 100.

6 Idem, p.101-102.

7 Idem, p.102.

8 Idem, p. 108. 
Tal hierarquização [...] primeiramente caminhava para enfatizar a capacidade das 'nações' indígenas de aderir aos 'cômodos da sociabilidade', observada mais em umas do que em outras" ${ }^{9}$. Ou seja, a hierarquização proposta dizia respeito à forma como os grupos indígenas respondiam à ação civilizadora.

Adotar, para os grupos indígenas do Império Brasileiro, o conceito de nações, significava, de certa forma, marcar uma fronteira entre a Nação brasileira e as diversas nações que habitavam o território brasileiro, "marcando ao mesmo tempo um outro pertencimento daqueles grupos por sua distinção em relação à boa sociedade. Afinal, não havia nações distintas dentro desta última"10. Contudo, "o jogo de luzes sobre as nações deveria privilegiar não toda a diversidade de grupos e etnias existentes no território do Império"11. Como bem verificou Kodama, pelo critério de hierarquização das etnias convertidas em nações, o índio escolhido para simbolizar a nacionalidade, pelo IHGB, era o Tupi, o índio do passado, o índio incorporado à nação pelo processo colonizador ${ }^{12}$.

Em sua análise sobre a atuação do IHGB na construção de uma história nacional para o Brasil, Kodama observa que a discussão sobre o lugar do índio estava presente desde a fundação do Instituto. Ela observa, também, que Martius foi um dos direcionadores dos estudos indígenas operados no IHGB, pois sua entrada no instituto marcou uma etapa mais científica da instituição $0^{13}$. Foi, portanto, com essa investidura científica que ele se preocupou em pensar

\footnotetext{
9 KODAMA, Kaori. Op., cit., p. 112

10 Idem, p. 107

11 Idem, p. 108

12 Idem, ibidem.

13 Idem, p. 179.
} 
a História do Brasil, se utilizando dos referenciais raciais do século XIX, o que evidenciava o estreitamento das relações entre o debate racial e a história nacional durante a segunda metade do século XIX. No bojo das suas preocupações acerca da presença das populações indígenas do Brasil, Martius lançou a tese da decadência do índio americano. Defendeu que o continente havia sido ocupado por civilizações avançadas, num tempo remoto, e o Brasil era indicado como lugar de existência dessas civilizações. Mas tais sociedades sofreram um processo de decadência ${ }^{14}$. Diante disso, qual era o lugar que ocuparia o índio na escrita da história e no Estado nacional brasileiro em construção?

Em carta direcionada ao secretário do IHGB, Joaquim Caetano Fernandes Pinheiro, em 1861, Martius elencava a importância do desenvolvimento de estudos no campo da geologia, paleontologia, vegetações antigas e da linguística para que os estudos etnológicos não caíssem no campo da especulação ${ }^{15}$. Martius, assim como Varnhagen, entendia que seria necessária uma diferenciação entre os campos da história e da etnologia. Nesse percurso, os estudos indígenas, no século XIX, eram cada vez mais realizados pelos "especialistas da história da natureza" e menos pelos historiadores ${ }^{16}$. Isso significava que "o lugar do índio, na história do Brasil, se definia por uma ordem que o colocava no seu início"17, através da construção histórica do seu lugar relacionado à natureza, ao passado primitivo do Brasil e "este 'lugar' primevo do índio seria encontrado como uma quase história dentro de outra maior"18.

14 KODAMA, Kaori. Op., cit., p. 154-155.

15 Idem, p. 180.

16 Idem, p. 181

17 Idem, ibidem.

18 KODAMA, Kaori. Op., cit., p. 181 
Manoel Luiz Salgado Guimarães, por sua vez, verifica, através da análise da fala do primeiro secretário perpétuo do IHGB, na ocasião da sua fundação, quais as funções exercidas pelo instituto na construção do projeto de nação brasileira. $\mathrm{O}$ autor observa que o Instituto atuaria como "administrador do passado", regularia não só a coleta de fontes, como também os temas para a execução do projeto de uma história nacional. Dessa forma, segundo Guimarães, foram indicados, pelo IHGB, "os procedimentos a serem postos em marcha para a construção de uma narrativa do passado que deve ser lembrado, quando o que está em questão é o relato das origens desta nação". ${ }^{19}$

Salgado Guimarães ressalta que é a partir da década de 1840 que, concretamente, se começa a cunhar uma história do Brasil. Constituía tal objetivo a instituição do prêmio conferido pelo IHGB à Von Martius, em 1847, que apresentou o mais satisfatório plano "a partir do qual se deveria escrever a história do Brasil" ${ }^{20}$. Naquele momento, a questão indígena era uma das principais preocupações sobre as quais se debruçavam os intelectuais do IHGB. Para o autor, a dedicação intelectual voltada para a questão indígena deve ser analisada em conexão com as discussões daquele momento. Ele indica três prismas correlacionados: o interesse histórico, o político e o econômico.

Os intelectuais de meados do século XIX não estavam apenas envolvidos em incluir os índios na história nacional, mas tratava-se, principalmente, de sua integração social,

19 GUIMARÃES, Manoel Luiz Salgado. “A disputa pelo passado na cultura histórica oitocentista no Brasil". In: CARVALHO, José Murilo de (Org.). Nação e cidadania no Império: novos horizontes. Civilização Brasileira, 2007, p. 99-100.

20 GUIMARÃES, Manoel Luiz Salgado. Historiografia e nação no Brasil: 1838-1857. Rio de Janeiro: EDUERJ, 2011. p.127. 
"viabilizando a realização de determinado 'processo civilizador'". ${ }^{21}$ Guimarães explicita o aspecto econômico como direcionador para entender os múltiplos discursos emergidos acerca dos índios. Ele ressalta que não foram os interesses econômicos que suscitaram a atenção dos intelectuais da década de 1840. Contudo, indica que, a partir daquele momento, "a perspectiva econômica da problemática indígena não pode mais ser desvinculada do debate acerca da escravidão" 22 , pois, naquele contexto, os latifundiários, em especial os do Rio de Janeiro, tinham que lidar com a imposição da proibição do tráfico de africanos por parte da Inglaterra. Nesse sentido, as ideias que propunham alternativas para a escravidão eram consideradas importantes. Como parte desse processo, "a reflexão a respeito dos índios devia contribuir para o desenvolvimento de eventuais alternativas à escravidão"23. Salgado Guimarães demonstra que nos textos envolvidos em escrever a história nacional, a integração indígena aparece como algo desejável ${ }^{24}$.

Como bem aponta Manoel Salgado Guimarães, o que emerge da produção historiográfica do IHGB é a preocupação com a integração indígena que deveria ser tratada como política de Estado. Os projetos e opiniões com relação à integração indígena à nação eram diversos e conflitantes. Em 1856, Domingos José Gonçalves de Magalhães publicou A confederação dos Tamoios, obra que atingiu repercussão pelo apoio recebido do Imperador Pedro II. Gonçalves de Magalhães defendia que a resistência indígena era uma luta justificada porque estava relacionada à violência empreendida pela conquista

21 GUIMARAES, Manoel Luiz Salgado. Op., cit., p.144.

22 Idem, p. 152.

23 Idem, p. 154.

24 Idem, p. 156. 
colonizadora. ${ }^{25}$ Para Gonçalves de Magalhães, os índios apresentavam "racionalidade e moral" que lhes conferiam "condições para ser considerados civilizados"26. Já Adolfo Varnhagen, contrário a Gonçalves de Magalhães, em sua História Geral do Brasil, defendia a integração indígena pelo uso da força. Varnhagen propunha o modelo bandeirante de integração dos índios, que passava pela iniciativa de particulares capturarem índios e lhes impor o trabalho nas lavouras. Para ele, as investidas de particulares na captura de índios e a concessão desses para disporem, por determinado período, do trabalho indígena, na lavoura, resolveria, em parte, a questão da substituição do trabalho escravo africano ${ }^{27}$.

Portanto, no guarda-chuva das ideias emergidas dos debates no IHGB acerca do Estado nacional brasileiro e dos índios, surgiram diversas vozes dissonantes. Interessada em analisar a atuação de alguns dos importantes integrantes do IHGB na construção de uma "história nacional", Vânia Moreira destaca mais um importante personagem desse debate. Além de Varnhagen e Gonçalves de Magalhães, a autora elenca, em seu estudo, as ideias de Joaquim Norberto Silva, para quem os direitos indígenas de terras, bem como outros direitos políticos e sociais, estariam salvaguardados pela designação a eles atribuída de "concidadãos". Como observa Moreira, Joaquim Norberto traz, em seu estudo sobre os indígenas das aldeias do Rio de Janeiro, o problema dos direitos de cidadania dos índios na nova ordem imperial, criados a partir da territorialização à qual os índios foram submetidos no intuito de

25 GUIMARAES, Manoel Luiz Salgado. Op., cit., p. 207.

26 Idem, p. 208.

27 Idem, p. 212. 
ressocializá-los; e a partir do problema da territorialidade, devido "à crescente identificação [dos] índios com a sociedade colonial e com as terras de suas novas aldeias" ${ }^{\prime 28}$.

Na perspectiva de Vânia Moreira, o índio considerado "brasileiro" por Gonçalves de Magalhães o era no sentido de sua incorporação e contribuição à nacionalidade como mão de obra disponível. Como asseverou a autora, “O 'índio' era, em outras palavras, ontologicamente transitório: deveria morrer culturalmente para nascer como brasileiro"29. E dizia ela que, dentre as ideias gestadas acerca do lugar do índio na construção da nação brasileira, prevaleceram as ideias de Magalhães, que foram incorporadas à "ação indigenista do Império".

O problema indígena é pensado e debatido no Império numa conjuntura complexa e emblemática, tendo em vista a diversidade de situações que permeavam aquele contexto, a saber: um país recém-criado, escravocrata, economicamente baseado na monocultura e empreendendo esforços para se inserir na arena internacional como um país moderno e civilizado. Para tanto, deveriam ser solucionados os problemas urgentes relacionados a essas questões, tais como a substituição da mão de obra escrava pela livre - utilizando, a exemplo de outros países, a política de imigração - o que, por sua vez, forçava o governo imperial a resolver a tardia, conflituosa e urgente questão da regulamentação da posse da terra no território nacional. Outro assunto urgente na pauta da política imperial, à época, dizia respeito à ocupação e exploração dos espaços territoriais mais afastados (os sertões), através da colonização

28 MOREIRA, Vânia Maria Losada. “O ofício do historiador e os índios: sobre uma querela no Império". Revista Brasileira de História. São Paulo, v. 30, n. 59, 2010c, p. 66.

29 Idem, p. 68. 
e, concomitantemente, da "civilização" dos "gentios" que inviabilizavam o sucesso de tal projeto governamental. Terra e colonização eram temas correlacionados na pauta política e administrativa do Oitocentos e frequentemente esbarravam na questão indígena.

Portanto, para resolver as questões políticas de terra e colonização, o governo imperial precisava encontrar, paralelamente, alternativas para solucionar o problema indígena. Cunha ressalta a importância de Bonifácio para a positivação do projeto imperial de nação, visto que seus Apontamentos para a civilização dos índios bravos do Império do Brasil tornaram-se referência para as instâncias governamentais, na Constituinte de 1823. A tese da brandura para a "civilização dos índios", por ele defendida como melhor alternativa para integração indígena à nação brasileira, emergia como uma das saídas possíveis e marcaria o engendramento das práticas indigenistas imperiais da segunda metade do século XIX.

Os debates pró e contra a "civilização indígena" por meio da brandura ecoavam nos espaços de debate e de produção intelectual durante a segunda metade do XIX, mesmo já tendo sido promulgado, naquela ocasião, o Regulamento das Missões, de 1845, que claramente optava pelo método brando. Embora as expectativas do Regulamento de 1845 fossem por em prática, nas missões de catequese, a ideia da brandura "a fim de civilizar os índios" para a vida em sociedade, mais especificamente para o trabalho, continuavam em voga as práticas coercitivas e violentas contra eles; práticas que, em grande medida, eram justificadas por posicionamentos teóricos semelhantes aos desenvolvidos por Varnhagen.

No decorrer das discussões, que vislumbravam atender às demandas políticas e econômicas do Império brasileiro, mais precisamente em 24 de julho de 1845, foi 
editado o Decreto $\mathrm{n}^{\circ} 426$, contendo o Regulamento acerca das Missões de cathequese, e civilização dos Índios, mais conhecido como "Regulamento das Missões".

O aparecimento de uma lei, tal qual o Decreto 426 na década de 1840, é bastante coerente com os novos rumos assumidos pelo governo. Após a ascensão de Dom Pedro II e a vitória dos grupos conservadores em prol da centralização, percebemos o intuito governamental de buscar para si o controle da questão indígena e, especialmente, das terras ocupadas por esses. ${ }^{30}$

Carneiro da Cunha frisa que o Decreto 426 foi o "único documento indigenista geral do Império"31. Afirma também que ele trazia um caráter mais administrativo do que propriamente político. O regulamento de 1845 dava permanência à política de aldeamento de catequese e o entendia "como uma transição para a assimilação completa dos índios" ${ }^{\prime \prime 2}$ à sociedade nacional. Em última análise, ele tinha por finalidade transformar o indígena em trabalhador através do processo catequético nos aldeamentos. Vale lembrar que, a partir de tal regulamento e da Lei de Terras de 1850, ocorrerá a gradual expropriação das terras indígenas para atender a política de expansão e colonização imperial.

O século XIX caracterizou-se por um crescente interesse pela terra, em que o que está em jogo é a expansão territorial do Império, com o objetivo de "alargar os espa-

30 MACHADO, Marina Monteiro. Op., cit., 2006, p. 100.

31 CUNHA, Manuela Carneiro da. Op., cit., p. 139.

32 Idem, ibidem. 
ços transitáveis e apropriáveis". ${ }^{33}$ Nesse contexto, os indígenas ocupam uma posição fundamental, pois tinham, dentre suas principais funções, a de trabalhar na pacificação de indígenas tidos como gentios, trabalhar na construção e preservação de vias de acesso (como as estradas) e servir como mão de obra na lavoura. Mais que isso, para Cunha, os índios ocupam lugar central, "já que têm de ser legalmente, senão legitimamente, despossuídos de uma terra que sempre lhes foi, por direito, reconhecida". ${ }^{34}$

Desse modo, a política para os índios, no Império, procurou subsidiar soluções para o problema de terras, colonização e trabalho, tal como afirmou Carneiro da Cunha. Segundo a autora, os aldeamentos implantados ao longo da segunda metade do século XIX serviam às mais diversas conveniências: "não só se tirava ou confinava em parcelas de regiões disputadas por frentes pastoris ou agrárias, mas se os levava também para onde se achava seriam úteis. [...] em rotas fluviais, [...] em rotas de tropeiros [...], os aldeamentos serviam de infraestrutura, fonte de abastecimento e reserva de mão de obra" ${ }^{35}$ No bojo desse processo, Manuela Carneiro da Cunha afirma que a questão indígena, no século XIX, sofreu uma transição: "deixou de ser uma questão de mão de obra para se tornar uma questão de terras" ${ }^{\prime \prime 6}$. Contudo, essa assertiva causa a impressão de uma efemeridade da atuação dos índios aldeados no processo colonizador do Oitocentos. É importante ressaltar a heterogeneidade demandada pelas diferentes regiões da colônia e posteriormente, das diferentes províncias do Império no que diz respeito à questão da colonização e da questão indígena.

33 Idem, p. 141.

34 CUNHA, Manuela Carneiro da. Op., cit., p. 141.

35 Idem, p. 144.

36 Idem, p. 133. 
Acerca dos direcionamentos da política indigenista, vigorados em início do século XIX, Celestino de Almeida observa que a Carta Régia de 1798, que extinguia o Diretório pombalino e dava outras diretrizes políticas, mantinha e acentuava o caráter assimilacionista do antigo Diretório para resolver a questão indígena. Nesse contexto, no caso do Rio de Janeiro, estudado por Almeida, "o desenvolvimento socioeconômico da capitania impulsionado pela presença da Corte afetaria tanto os índios das aldeias quanto os dos sertões. O crescimento populacional e o aumento da demanda por terras pressionavam-nos em dois sentidos: pela extinção, em áreas de ocupação antiga [...]; e pela ocupação de novas áreas" ${ }^{37}$ Desse modo, observa Almeida, as aldeias tardias, se comparadas às antigas aldeias coloniais, eram marcadas por um curto período de atuação. Nas palavras da autora,

As novas aldeias estabelecidas nesse período teriam vida curta, pois já se estabeleciam, conforme as leis pós-Diretório, com intenção de civilizar e assimilar, o mais rápido possível, os recém-aldeados. O processo de transformação dessas aldeias tardias em freguesias e vilas, com o aumento cada vez maior de não índios em seu interior, apresenta consideráveis semelhanças com os aldeamentos antigos, porém num ritmo muitíssimo mais acelerado. Se nesses últimos, o movimento se fez em torno de três séculos, nas primeiras, ele ocorreu em cerca de três décadas ${ }^{38}$.

Também com relação aos aldeamentos implantados sob a vigência do Regulamento de 1845, Kaori Kodama

37 ALMEIDA, Maria Regina Celestino de. Os índios na história do Brasil. Rio de Janeiro: Editora FGV, 2010, p. 142.

38 Idem, p. 142-143. 
observa o caráter de transitoriedade das aldeias. Segundo Kodama, "a transitoriedade das aldeias, que em parte pode ser deduzida do próprio ditame das leis, encontrava outra confirmação prática e funesta quando levados em consideração os resultados do decreto n. 426 relatados pelos presidentes de província" ${ }^{\prime 3}$. Observa a autora que os principais problemas para a rápida extinção dos aldeamentos pautava-se na falta de administração e de verbas destinadas para tais, nas doenças que acometiam as aldeias e nos conflitos entre os índios e os não índios.

Levando-se em conta que a aplicação da política pós-Diretório Pombalino "continuou variando, conforme as diferentes categorias de índios e sua inserção em regiões com situações econômico-sociais diversas" ${ }^{\prime 4}$, como Almeida mesmo assegura, pontuamos as diferenças observadas na Bahia, em contraponto à realidade observada por Almeida, para o Rio de Janeiro. A transitoriedade das aldeias, como uma possibilidade Governativa para a realidade do sul da Bahia, surge apenas nas últimas décadas do XIX. Antes disso, a documentação evidencia que havia muito interesse do governo e dos particulares em manter os aldeamentos em funcionamento.

Mostra disso foi a convivência de antigos e novos aldeamentos em Ilhéus. As observações de Dias acerca da proeminência dos aldeamentos jesuíticos da capitania e comarca de Ilhéus apontam, no quadro demonstrativo da população de Santo Antônio de Jequiriçá, de 1720-1757, a existência da aldeia Jequiriçá́ ${ }^{41}$. O autor também faz menção à aldeia de São Fidélis, cuja primeira referência de sua existência é uma descrição do vigário Joaquim Pereira da

39 KODAMA, Kaori. Op., cit., p.261.

40 ALMEIDA, Maria Regina Celestino de. Op., cit., 2010, p. 141.

41 DIAS, Marcelo Henrique. Op., cit., 2007a, p. 220. 
Silva, de $1757^{42}$, além da aldeia de Barcellos ${ }^{43}$. Já Teresinha Marcis aponta que a instalação do aldeamento de São Miguel, em Camamu, teria ocorrido por volta de 1561, com 2000 índios $^{44}$. Todos esses Aldeamentos coloniais aparecem nos quadros demonstrativos das aldeias da Província da Bahia, de 1855 a 1861, juntamente com os aldeamentos instalados ao longo do XIX, conforme demonstram os Anexos 1 e 2.

A atuação conjunta de aldeamentos jesuíticos e dos tardios, que obedeciam à legislação imperial, demonstra a longevidade dos aldeamentos antigos e uma maior permanência dos aldeamentos tardios na realidade do sul da Bahia se comparada à realidade estudada por Almeida, pois aqueles perduraram por boa parte do Oitocentos. Ou seja, diferentemente das orientações legais do Império acerca da questão indígena, das práticas de rápida assimilação e extinção dos aldeamentos observadas em outras províncias, tomando como exemplo o Rio de Janeiro, estudado por Almeida no sul da Bahia, a permanência de antigos e novos aldeamentos era desejável aos propósitos governamentais e particulares, pelo menos até a década de 1860.

Em outros momentos deste estudo, demonstramos que a região sul da Bahia era intensamente ocupada por populações indígenas resistentes ao processo da colonização: Camacãs, Botocudos e Pataxós. Portanto, fazia-se necessário e fundamental, ao projeto colonizador, a permanência dos aldeamentos, para fins da pacificação territorial e instalação de colonos na região, bem como para servirem

\footnotetext{
42 Idem, p. 242.

43 Idem, p. 194.

44 MARCIS, Teresinha. Op., cit., p. 190.
} 
de mão de obra para os trabalhos públicos e particulares. Conforme o mapeamento dos registros documentais, essa configuração regional mudará especialmente a partir da década de 1870, quando observamos outra conformação na política indigenista destinada ao sul da Província da Bahia, aspecto que abordaremos no último tópico deste capítulo.

\subsection{A "extinção" do Aldeamento São Pedro de Alcântara e os primeiros passos da Colônia Nacional em Ferradas}

As práticas governativas com relação aos aldeamentos de parte da região sul da Bahia, entre Ilhéus e Conquista, nas últimas décadas do século XIX, foram subsidiadas pelos interesses políticos e econômicos demandados dos desdobramentos da Lei de Terras de 1850 e seu regulamento, que nas palavras de Carneiro da Cunha, "inaugura uma política agressiva em relação às terras das aldeias". ${ }^{45}$ Celestino de Almeida ressalta que, conjuntamente, o Decreto 426, a Lei de terras de 1850 e o Regulamento de 1854 "incentivavam a proposta assimilacionista e continuavam garantindo o direito dos índios às terras coletivas enquanto eles não atingissem o chamado estado de civilização". ${ }^{46}$

Para a realidade do sul da Bahia de fins do Oitocentos, significa dizer que, no contexto de expansão das terras cultiváveis, as práticas assimilacionistas em relação aos aldeados foram visíveis, com vistas à usurpação de suas terras e exploração de sua mão de obra na lavoura regional. Nesse processo, verificamos que, a partir do final da

45 CUNHA, Manuela Carneiro da. Op., cit., p. 145.

46 ALMEIDA, Maria Regina Celestino de. Op., cit., 2010, p. 152. 
década de 1860, a preocupação gestada nos relatórios e falas provinciais passa, principalmente, pela questão da imigração, sobretudo a nacional. Acerca disso, notamos que a partir desse momento se começa um processo de desmonte dos aldeamentos e tudo leva a crer que muitos deles eram transformados em colônias nacionais agrícolas implantadas a partir do final da década de 1850. As colônias configuravam uma nova estratégia política do governo provincial direcionada a resolver os problemas da colonização e dos indígenas no sul da Bahia, em fins do XIX, como tentaremos demonstrar adiante.

Nas falas e relatórios, ecoam as notícias dos diretores gerais, que insistem sobre o abandono dos aldeamentos, a falta de verba para mantê-los e de missionários. Essas reclamações culminam na estratégica ideia de extinção dos aldeamentos e de liberação das terras dos mesmos para fins da colonização. Como bem observa Almeida,

na segunda metade do século XIX, a intensa correspondência oficial entre autoridades do governo central, das províncias e dos municípios é reveladora da preocupação do estado em obter o máximo de informações possíveis sobre os aldeamentos e os índios com o nítido objetivo de dar cumprimento à política assimilacionista, a ser implementada conforme as situações específicas de cada região. Não é de estranhar, portanto, que o conteúdo desses documentos insistisse tanto na decadência, miserabilidade e diminuição dos índios e suas aldeias ${ }^{47}$.

A exemplo do que ressalta Almeida, registra-se, no Relatório Provincial da Bahia, de 1869, a seguinte conclusão:

47 ALMEIDA, Maria Regina Celestino de. Op., cit., 2010, p. 154. 
Há alguns annos como que se tem esquecido este assumpto aliás bem interessante para o futuro da província ante a necessidade de braços para a lavoura, cada vez mais sensível e objecto de serias apprehensões. Figura nos orçamentos uma verba quase nulla, da qual mui pouco se gasta com alguns padres capuchinhos encarregados do aldeiamento de índios [...] podendo asseverar porém que a maior parte d'elles estão no caso de serem extintos, e seus bens devolvidos à fazenda nacional, ou para outro qualquer destino que lhes dê a assembléia geral ${ }^{48}$.

Nesse processo, registramos a suposta extinção do Aldeamento São Pedro de Alcântara ou Aldeamento de Ferradas, que, estranha e subitamente, desaparece da documentação. $\mathrm{O}$ aldeamento de Ferradas era considerado como o mais importante da província da Bahia, em $1853^{49}$; apesar disso, ao final da década seguinte, o que temos acerca daquele estabelecimento são vestígios de sua "extinção". Não é demais lembrar que as terras do aldeamento e da região estavam ocupadas com o cultivo da lavoura do cacau que, na década de 1860, já exportava o produto e despertava cada vez mais o interesse dos colonos pelas férteis terras daquela parte do sul da Bahia.

Em 1868, o juiz Antônio Villaça endereçava ao presidente da Província, Barão de S. Lourenço, uma correspondência na qual relatava o andamento dos trabalhos na

48 Relatório do presidente da província da Bahia, de 1869, p.72-73. In: Falas e Relatórios Provinciais Presidenciais (1830-1930). Disponível em: < http: / / www.crl.edu/brazil/provincial/bahia $>$.

49 Conforme a fala presidencial de João Maurício Wanderley, de $1^{\circ}$ de março de 1853, p. 35: [...] o mapa n. 9. Mostra quaes as aldeãs existentes na Província [...]. O principal e mais importante destes aldeamentos he o de São Pedro d' Alcantara, situado à margem setentrional do rio Cachoeira, 12 légoas acima da Villa de Ilhéos. 
estrada Ilhéus-Conquista. Nela o juiz registrava que tal empreendimento estava a cargo do fazendeiro Fernando de Steiger, que alargava na região os seus negócios, comprando terras do governo; Villaça também registrava que a estrada oferecia muitas dificuldades, na altura do rio Cachoeira, da Vila de Ilhéus até a antiga Aldeia de Ferradas ${ }^{50}$. Ou seja, não sabemos exatamente em que momento São Pedro de Alcântara foi oficialmente extinta. O certo é que, em 1868, parecia já estar cessada a atuação da aldeia, como atesta a correspondência do juiz de Ilhéus ao presidente da Província. Os interesses eram outros naquela região, à época. Nota-se, portanto, uma maior interação das relações governamentais e do empreendedorismo particular, haja vista os trabalhos da estrada ficarem aos cuidados e interesses dos fazendeiros da região.

Nesse processo, coloca-se em prática, naquela zona sul da Bahia, o projeto de implantação da colônia nacional denominada de Cachoeira dos Ilhéus ou Cachoeira de Itabuna. O desembargador João Antônio de Araújo Freitas Henriques, presidente da Província, menciona, em 1872, que o seu antecessor havia criado a "Colônia da Cachoeira por acto de 25 de abril de 1870, aprovado pela lei de 17 de junho do mesmo anno" 51 .

$\mathrm{Na}$ mesma ocasião, Freitas Henriques menciona a situação da Colônia de Comandatuba, também localizada no sul da Bahia. Destaca que a população da Colônia contava com 555 pessoas até junho de 1872. Contudo, o número de pessoas teria decaído: "tendo sahido 93 para a colônia das

50 APEB: Seção Arquivo Colonial e Provincial; Série Justiça/juízes de Ilhéus (1868-1870); maço 2401; 16 de agosto de 1868, fl. 8.

51 Fala do presidente da Província da Bahia, de $1^{\circ}$ de março de 1872, p. 144. In: Falas e Relatórios Provinciais Presidenciais (1830-1930). Disponível em: <http:/ / www.crl.edu/brazil/provincial/bahia >. 
Ferradas e outros logares"52. A informação de que a Colônia estava localizada em Ferradas, deixa forte indício quanto à sobreposição da Colônia ao Aldeamento São Pedro de Alcântara.

Não pretendemos neste estudo, nos debruçar sobre a colônia nacional agrícola e as questões a ela relacionadas. Esse tema é uma questão complexa e merece uma nova pesquisa para dar conta de suas dimensões mais significativas para a construção da história dos índios. Contudo, algumas considerações acerca do novo projeto de colonização se fazem pertinentes e necessárias para entender o contexto de esfacelamento do Aldeamento São Pedro de Alcântara.

Nesse quadro, delineia-se um apagamento da presença dos aldeados de Ferradas na região; isso é estranho porque, outrora, eles eram os grandes colaboradores do governo e dos particulares da região. Estamos falando de uma década de antecedência, apenas. A última notícia encontrada sobre a manutenção do aldeamento data de 1860 . O senador Herculano Ferreira Penna destaca que o novo responsável pela aldeia de Ferradas, a partir de então, seria o capuchinho Luís de Grava, "que foi transferido da aldeia de Catolé". ${ }^{53}$

Frei Luis de Grava chegou à Bahia em agosto de 1853, mas já tinha atuado anteriormente em Pernambuco e Alagoas, como esclarece Pietro Vittorino Regni, para quem o frade representava, no sul da Bahia, a continuação do trabalho de Ludovico de Livorno ${ }^{54}$. Nesses termos, observa Telma de Souza que Luís de Grava "seria o grande

52 Idem, p. 142.

53 Fala do presidente da Província da Bahia, de $1^{\circ}$ de abril de 1860, p. 32. In: Falas e Relatórios Provinciais Presidenciais (1830-1930). Disponível em: $<$ http:/ / www.crl.edu/brazil/provincial/bahia $>$.

54 REGNI, Pietro Vittorino. Os capuchinhos na Bahia: uma contribuição para a história da Igreja no Brasil. Volume 2. Gráfica Editora Palloti. 1988, p. 501. 
responsável pelo treinamento de mão de obra indígena na região sul da Bahia". ${ }^{55}$ Ele sucedeu Ludovico de Livorno, que atuou por três décadas em Ferradas e demais localidades do sul da Bahia, na posição de administrador da mão de obra indígena, como já trabalhamos densamente em outro momento da dissertação.

Luís de Grava, em fins do século XIX, foi a figura religiosa e administradora do trabalho indígena mais atuante na região sul da Bahia. Sua atuação está intrinsecamente relacionada aos rumos da política de colonização e administração do trabalho indígena em fins do Oitocentos. Frei Luís de Grava, após a "extinção" do aldeamento São Pedro de Alcântara, permaneceu em Ferradas, responsável pela administração da colônia nacional ali implantada. Além da Colônia Cachoeira, ele administrava paralelamente as aldeias de Barra do Catulé, Santo Antônio da Cruz e Cachimbo. Na documentação da década de 1870, Cachimbo é mencionado como convertido em um estabelecimento nacional, conforme observamos na fala presidencial de Antônio Cândido da Cruz Machado, em 1874:

A colonização estrageira tem sido infeliz em nossa Província [...]. Neste caso com a cathequese poderíamos obter colonização, como o tem conseguido o virtuoso Fr. Luís de Grava, que organisando o aldeiamento do Cachimbo, acha-se hoje convertido num vasto e populoso arraial, entreposto de commercio para a Villa da Victória e está organizando actualmente a colônia da Cachoeira, ao sul da província, bastante florescente ${ }^{56}$.

55 SOUZA, Telma Mirian Moreira de. Op., cit., p. 169.

56 Fala do presidente da província Antônio Cândido da Cruz Machado, $1^{\circ}$ de março de 1874, p. 109. In: Falas e Relatórios Provinciais Presidenciais (18301930). Disponível em: <http: / / www.crl.edu/brazil/provincial/bahia >. 
Reforçando a fala do diretor geral dos índios da Bahia, o Visconde de Sergimirim, Vittorino Regni, ressalta a atuação de Cachimbo "como uma das experiências mais bem sucedidas e mais duradouras no processo de integração de aborígenes na sociedade" ${ }^{57}$. Em outras palavras, no sul da Bahia, a instalação de colônias agrícolas em áreas de extintos aldeamentos ou próximas a eles, como era o caso de outras colônias instaladas na região, tinha uma dupla função: agregar o contingente de imigrantes nacionais para a ocupação territorial e o trabalho na lavoura do cacau, além de subsidiar o processo de integração do índio como trabalhador nacional.

Em se tratando da colônia Cachoeira de Itabuna, no relatório presidencial, Venâncio José de Oliveira Lisboa destaca que a colônia chegava "a ser quase o centro civilizador dos índios selvagens de toda a circunvizinhança, dos quaes é missionário e dedicado cathequista o seu Director Frei Luiz de Grava". ${ }^{58} \mathrm{O}$ interesse na integração indígena era um dos objetivos de fazer funcionar as colônias nas áreas densamente habitadas por populações indígenas, como podemos aventar a partir dessas considerações iniciais, empreendidas acerca das colônias nacionais agrícolas. As considerações expostas traduzem o esforço inicial de se produzir algumas reflexões em torno do novo projeto de colonização colocado em prática no sul da Província, no final do século XIX.

Portanto, não temos uma resposta clara e definitiva sobre o desmonte do aldeamento São Pedro de Alcântara. Mas isso se deu em um processo no qual foi incentivado

57 REGNI, Pietro Vittorino. Op., cit., p. 503.

58 Relatório do presidente da Província da Bahia Venâncio José de Oliveira Lisboa, $1^{\circ}$ de março de 1875, p. 52. In: Falas e Relatórios Provinciais Presidenciais (1830-1930). Disponível em: <http:/ / www.crl.edu/brazil/ provincial/bahia $>$. 
o projeto de colonização direcionado para o sul da Província, passando da estratégia de manutenção de antigos aldeamentos para sua extinção e instalação das colônias agrícolas, as quais deveriam integrar os índios a fim de assimilá-los em definitivo. O processo da suposta extinção do aldeamento não deve ser analisado como simples prática governamental de liberação das terras do Aldeamento, pois foi um processo complexo, e deve ser estudado e analisado com o devido cuidado. Por ora, podemos considerar que o aldeamento deixou de existir administrativamente em fins da década de 1860 . Contudo, os indícios documentais deixam evidências de que o novo projeto implementado não excluía os índios de Ferradas, haja vista a afirmação de que nos primeiros momentos da instalação da Colônia, "os trabalhos prosseguiam em ritmo acelerado, com o emprego de 51 trabalhadores alugados e de alguns índios catequizados" ${ }^{\prime \prime}$. Ou seja, o aldeamento foi supostamente extinto, mas a presença e a atuação dos índios de Ferradas continuavam na região.

5.3 Os meandros da política indigenista nas práticas administrativas no sul da Província da Bahia e a ideia de desaparecimento dos índios do "antigo aldeamento"

Nessa última etapa do capítulo, tentaremos demonstrar que uma das facetas da política indigenista em Ferradas foi a invisibilização da presença dos homens e mulheres indígenas de São Pedro de Alcântara, no período que se seguiu à aparente extinção do referido Aldeamento

59 REGNI, Pietro Vittorino. Op., cit., p. 505. 
e instalação da Colônia Agrícola naquela localidade. A despeito da característica regional de intensa resistência de muitos grupos indígenas não aldeados e habitantes da região sul da Bahia, os indígenas outrora ali aldeados desaparecem da documentação enquanto atores ou objeto de políticas governamentais específicas, num processo de ocupação territorial que permanece conflituoso durante todo o século XIX. Nesse contexto, o que parecia estar em jogo não era apenas o esforço em assimilar os aldeados e extinguir os aldeamentos; outro efeito que parece bastante em evidência na política indigenista de fins do Oitocentos, no sul da Bahia, foi o desaparecimento sociocultural das antigas populações de aldeamentos, a exemplo da de Ferradas.

Caso não tivéssemos acesso a uma ampla massa de documentos registrando o intercâmbio entre autoridades provinciais e locais acerca da atuação dos aldeados de São Pedro de Alcântara, e empreendêssemos uma leitura desatenta dos registros referentes à colônia nacional, muito provavelmente instalada em Ferradas, a partir da década de 1870, nem de longe poderíamos vislumbrar que, outrora, havia funcionado naquelas paragens o aldeamento.

Os índios de Ferradas pareciam ter sido extintos juntamente com o aldeamento. Essa ideia não deve ser vista como mero desinteresse provincial e local para com os índios advindos de antigos aldeamentos, mas como uma estratégia premeditada de invisibilização indígena. Naquele momento, a meta parecia ser extirpar, social e culturalmente, os antigos aldeados, já que a sua invisibilização na documentação fazia denotar a inexistência dos índios na localidade do "antigo estabelecimento" colonial; à medida que na documentação desaparece a categoria de índio para designar Ferradas, surge a falsa impressão da inexistência deles no núcleo de povoamento. A partir de 
então, eles deveriam fazer parte da massa trabalhadora da região, bem como suas terras expropriadas, pois, àquela altura, a lavoura do cacau demandava mão de obra disponível e terra cultivável para a sua expansão.

A Província da Bahia, a partir da segunda metade do século, estava voltada para os interesses da imigração por meio da instalação das colônias estrangeiras e nacionais. Nesse processo, a atuação indígena continuava a despertar certo interesse provincial pelos aldeamentos, pois notamos nos, direcionamentos acerca de uma política de imigração para a província, a preocupação com o total abandono dos aldeamentos, presente nos relatórios e falas presidenciais. Contudo, o interesse pela questão indígena se dava por outros objetivos. Naquele contexto, o discurso oficial evidenciava o interesse nos aldeamentos com vistas a integrar rapidamente os índios; não interessava mantê-los em comunidades de índios aldeados. A meta em vigência parecia basear-se na seguinte premissa: "aproveitar as tribus, que andam pelas mattas, infestam as estradas e acommetendo as fazendas é, principalmente agora [...], um serviço relevante a lavoura". ${ }^{60}$

Desse modo, não é demais ressaltar que, nesse processo, a política de instalação das colônias não dispensa a atuação indígena como mão de obra; pelo contrário, alguns aldeamentos continuam funcionando ao lado das colônias e outros são institucionalmente dissolvidos nelas. Desse ângulo, as colônias tornaram-se espaços nos quais atuam índios e colonos, momento de maior incentivo à mistura dos índios no processo de colonização e exploração territorial. Portanto, política de colonização agrícola e

60 Fala do presidente da província João Antônio de Araújo Freitas Henriques, $1^{\circ}$ de março de 1872, p. 144. In: Falas e Relatórios Provinciais Presidenciais (18301930). Disponível em: <http:/ / www.crl.edu/brazil/provincial/bahia>. 
política indigenista, no sul da Bahia de fins do Oitocentos, são interesses que caminharão correlacionados, sobretudo com vistas a atender a demanda de consolidação da lavoura do cacau na comarca de Ilhéus.

Alguns estudos atestam uma situação de crise de mão de obra na Província da Bahia durante a segunda metade do século XIX, tendo como fator gerador principal a iminente diminuição da utilização da mão de obra escrava africana na lavoura, através da asseveração contra o tráfico de escravos. Henrique Buckingham Lyra, em seu estudo A "crise" de mão de obra e a criação de colônias agrícolas na Bahia: 1850-1889, concorda que tenha havido uma crise de mão de obra na província baiana na segunda metade do século XIX. Contudo, ele defende a ideia de que não houve exatamente escassez de força de trabalho livre na Província, mas um excesso de mão de obra ociosa do norte ${ }^{61}$. Segundo os dados demográficos demonstrados pelo autor, a Província contava com uma população livre de $87,84 \%$ na década de $1870^{62}$. Portanto, na sua perspectiva, o problema não era escassez de mão de obra livre na província da Bahia, mas sua grande concentração na região norte.

Para construir sua hipótese de que a crise baiana não era de falta de mão de obra, Lyra dialoga com Luiz dos Santos Vilhena, que trabalha a ideia de população urbana e rural ociosa na Bahia, de fins do século XVIII. Para Lyra, o projeto de implantação das colônias agrícolas nacionais ao sul da província, colocado em prática na segunda metade do século XIX, estava voltado a resolver, principal-

61 LYRA, Henrique Buckingham. "A 'crise' de mão de obra e a criação de colônias agrícolas na Bahia: 1850-1889". In: DIAS, Marcelo Henrique; CARRARA, Ângelo Alves (Orgs.). Um lugar na história: a capitania e comarca de Ilhéus antes do cacau. Ilhéus: Editus, 2007, p. 250.

62 Idem, p.245. 
mente, um problema social. Segundo ele, as colônias serviam para sanar o problema do excedente da população atingida pelas constantes secas no norte da Bahia, "pois os miseráveis migravam para as cidades e se dedicavam à mendicância". ${ }^{63}$

Em 1857, foram implantadas quatro das sete colônias: Snimbu, Nacional do Rio de Contas, Nacional Agrícola e Salto do Rio Pardo; em 1867, foi implantada a colônia de Comandatuba; em 1870, a Colônia Cachoeira de Itabuna, e em 1877, a Colônia Jequiriçá. Além das colônias nacionais, foram implantadas também quatro colônias estrangeiras por intermédio da empresa Moniz ${ }^{64}$. Vale destacar que todas estas colônias foram implantadas ao sul da Província.

Todas as colônias nacionais foram criadas sob o comando do governo. A Colônia Cachoeira de Itabuna foi uma das últimas a serem instaladas no sul da Bahia. Contudo, na fala presidencial de $1874^{65}$ e no estudo do historiador capuchinho Vittorino Regni ${ }^{66}$, o aldeamento de Cachimbo também aparece como um empreendimento nacional, mas não é citado por Lyra. É importante observar que tanto a Colônia Cachoeira quanto o estabelecimento de Cachimbo funcionam como centro de integração indígena. Elas estavam situadas nos rios Cachoeira e Pardo, região de maiores interesses para a expansão e exploração das terras para fins da agricultura e comércio, pois ligava as vilas IlhéusConquista como já demonstramos, bem como uma região ainda densamente habitada por indígenas que não teriam

63 LYRA, Henrique Buckingham. Op., cit., p. 247.

64 Idem, p. 253.

65 Fala do presidente da província Antônio Cândido da Cruz Machado, $1^{\circ}$ de março de 1874, p.109. In: Falas e Relatórios Provinciais Presidenciais (18301930). Disponível em: <http: / / www.crl.edu/brazil/provincial/bahia >.

66 REGNI, Pietro Vittorino. Op., cit., p. 503 
sofrido o processo da territorialização nos aldeamentos de catequese.

De fato, a partir da segunda metade do século XIX, os olhares do governo se voltam com mais interesse para o sul da Província, onde já se destacava a promissora lavoura do cacau, cujos frutos já eram exportados e viriam a representar a substituição, na agricultura, da cana de açúcar. No entanto, discordamos da tese de Lyra, de que as colônias foram pensadas e instaladas para resolver o problema do excedente populacional do norte da Província, direcionando os homens e mulheres pobres para a lavoura do cacau no sul da Bahia, apenas. Não negamos o interesse governamental de assentar moradores do norte ao sul da Bahia como trabalhadores da lavoura de cacau, pois a própria documentação atesta tal assertiva, contudo, entendemos que um objetivo central do governo na instalação das colônias no sul da Bahia e, silenciado por Lyra, era a positivação da colonização na região, que dizia respeito diretamente à integração dos índios ao projeto nacional.

O otimismo quanto à expansão agrícola na região sul pode ser explicitado pela descrição feita por Francisco Gonçalves Martins, em 1870, de que ela era o celeiro da Província da Bahia ${ }^{67}$. Além de Martins, outros presidentes da província manifestaram interesse pelas comarcas do sul da Bahia e pela colonização nacional. O presidente Antônio da Costa Pinto menciona que:

São as comarcas do sul a parte da província que, com mais afinco, devem

67 Relatório do presidente da província Francisco Gonçalves Martins, 1870, p. 35. In: Falas e Relatórios Provinciais Presidenciais (1830-1930). Disponível em: <http: / www.crl.edu/brazil/provincial/bahia>. 
ser exploradas. Ali, de preferência a todos os lugares, deve-se plantar a colonização nacional, por ser a mais própria para resistir as enfermidades, que soem apparecer durante as explorações de terrenos pouco habitados ${ }^{68}$.

Quanto à assertiva da necessidade de exploração de terrenos pouco habitados, entenda-se não ocupados pela colonização, pois eram densamente habitados pelos índios. Discutia-se, nesse contexto, as vantagens da colonização nacional em detrimento da estrangeira na província baiana. Como lembra Cunha, em fins do Oitocentos, se inicia o processo de intensificação das "vagas de imigrantes livres" no Brasil ${ }^{69}$. Também Almeida observa que na segunda metade do século XIX, a política voltada para resolver o problema indígena está calcada na ideia de civilização sobre a de catequização e, para alcamçar tal objetivo se incentivava, inclusive, a instalação de "outras formas de assentamento em regiões de fronteiras internas e externas"70, como era o caso dos presídios "estabelecidos como colônias militares, nas quais se instalavam os índios que, uma vez 'pacificados', contribuiriam para defender as regiões e ao mesmo tempo atrair novos grupos" ${ }^{71} \mathrm{Em}$ fins do século XIX, essas novas formas de assentamento no sul da Bahia se configuravam nas colônias agrícolas nacionais, que, no fim das contas, deveriam promover a interação das populações indígenas aldeadas com os nacionais

68 Fala do presidente da província Antônio da Costa pinto, $1^{\circ}$ de março de 1861, p. 33. In: Falas e Relatórios Provinciais Presidenciais (1830-1930). Disponível em: <http: / / www.crl.edu/brazil/provincial/bahia >.

69 CUNHA, Manuela Carneiro da. Op., cit., p. 133.

70 ALMEIDA, Maria Regina Celestino de. Op., cit., 2010, p. 144.

71 Idem, ibidem. 
e também atrair e assimilar aqueles grupos que não haviam sido submentidos à catequese nos aldeamentos. $\mathrm{A}$ ideia gestada nas correspondências oficiais, acerca desse assunto, deixava claro que as colônias deveriam funcionar como centro civilizador, promovendo a catequese, e podendo obter a colonização, como vinha conseguindo "o virtuoso Fr. Luis de Grava". ${ }^{72}$

Nesse sentido, é pertinente pensarmos a realidade do sul da Bahia, o desenho de todo o processo político direcionado à expropriação das terras das populações indígenas, delineado por Manuela Carneiro da Cunha:

O processo de espoliação torna-se, quando visto na diacronia, transparente: começase por concentrar em aldeamentos as chamadas "hordas selvagens", liberando-se vastas áreas, sobre as quais títulos eram incontestes, e trocando-as por limitadas terras de aldeias, ao mesmo tempo, encoraja-se o estabelecimento de estranhos em sua vizinhança; concedem-se terras inalienáveis às aldeias, mas aforam-se áreas dentro delas para o seu sustento; deportam-se aldeias e concentram-se grupos distintos; a seguir, extinguem-se aldeias a pretexto de que os índios se acham "confundidos com a massa da população"; ignora-se o dispositivo de lei que atribui aos índios a propriedade da terra das aldeias extintas e concedem-se-lhes apenas lotes dentro delas; revertem-se as áreas restantes ao Império e depois à província, que as repassam aos municípios para que as vendam aos foreiros ou as utilizem para a cria-

72 Fala do presidente da província Antônio Cândido da Cruz Machado, $1^{\circ}$ de março de 1874, p. 109. In: Falas e Relatórios Provinciais Presidenciais (18301930). Disponível em: <http:/ / www.crl.edu/brazil/provincial/bahia> . 
ção de novos centros de população. Cada passo é uma pequena burla, e o produto final, resultante desses passos mesquinhos, é uma expropriação total ${ }^{73}$.

Entendemos o processo de extinção das aldeias de fins do século XIX, no sul da Bahia, como um duplo movimento: expropriação territorial e esforço de promoção da extinção das identidades culturais indígenas e suas formas de organização social. Esse procedimento deve ser visto de forma complexa, no qual atuaram tanto autoridades administrativas, quanto religiosas e também os moradores da região sul da Bahia.

A atuação de uma política de colonização agrícola subsidiada por uma política indigenista de fins do Oitocentos, no sul da Bahia, tinha como fim premeditado invisibilizar etnicamente os índios de "antigos aldeamentos", a exemplo dos aldeados de Ferradas. Contudo, a própria leitura intercruzada da documentação utilizada neste estudo permite perceber que eles permaneceram no lugar do "antigo aldeamento". Garantia disso é a observação apresentada no estudo de Talita Ferreira ${ }^{74}$ sobre a atuação do Serviço de Proteção ao Índio, no sul da Bahia, que registra a presença dos índios em Ferradas quase meio século após a extinção do aldeamento, sendo, inclusive e contraditoriamente ao discurso do desaparecimento deles, reconhecidos pela categoria de "índios". O que, por sua vez, reflete todo um processo de colonização oitocentista ambíguo e complexo.

Em estudo sobre o Posto Indígena Catarina Caramu-

73 CUNHA, Manuela Carneiro da. Op., cit., p. 146.

74 FERREIRA, Talita Almeida. Posto Indígena Paraguaçu: Território de conflitos e resistências indígenas (1026-1936). Monografia de especialização. Universidade Estadual de Santa Cruz. Ilhéus-BA, 2012. 
ru Paraguaçu, no contexto de atuação do Serviço de Proteção ao Índio (SPI), no sul da Bahia, Ferreira observa que o órgão passou a atuar na região sul da Bahia imediatamente após a sua fundação. A autora ressalta que, em 1910, funcionários do SPI visitaram a região no intuito de preparar a instalação do referido posto indígena. Destaca a atuação de Pedro Maria Trompowsky Taubois como o primeiro inspetor do SPI na Bahia, cujo relatório apresentado ao subdiretor da segunda subdiretoria, em 1911, mencionava que índios pacificados de Ferradas auxiliariam na tarefa de contatar os índios da região, a fim de serem arregimentados para o posto que funcionaria nas proximidades dos rios Gongogy e de Contas ${ }^{75}$.

Entendemos a relação do processo de colonização sul baiana, de fins do Oitocentos, com as populações de extinto aldeamento como ambígua. Os antigos aldeados de Ferradas estavam sendo reconhecidos como índios, após um contexto no qual o que parecia estar em jogo era uma política e um discurso indigenista de invisibilização sociocultural dos índios do "extinto aldeamento", através da sua integração à Colônia Nacional da Cachoeira. Em 1911 quase meio século após a suposta extinção de São Pedro de Alcântara, os índios de Ferradas continuam atuando na região e, embora mencionados como índios pacificados, eles estão sendo reconhecidos como índios. Observar os índios do antigo aldeamento atuando na região em 1911, nos permite afirmar que eles não foram banidos social e culturalmente, como pareciam querer demonstrar a política e o discurso indigenistas de fins do século XIX.

75 FERREIRA, Talita Almeida. Op., cit., p. 26-27. 


\section{CONSIDERAÇÓES FINAIS}

Os aldeamentos de catequese geridos pelos frades capuchinhos italianos, oriundos da política indigenista do Oitocentos, foram parte essencial para alçar os propósitos da colonização do sul da Província da Bahia; integrou esse processo o aldeamento de Ferradas, tendo sido considerado, inclusive, em meados do XIX, o principal aldeamento da Província. Na década de 1860, contudo, uma nova configuração foi desenhada para a relação dos índios com o empreendimento colonizador no sul da Bahia, e a documentação permitiu perceber novos rumos para a inserção indígena no projeto de desenvolvimento regional. Na década de 1960, um século depois, o esforço da escrita memorialista de Itabuna, realizada pela elite herdeira do cacau, construiu uma história para a cidade na qual os índios foram propositalmente invisibilizados. Este estudo, portanto, se ocupou em compreender esse processo, tendo os índios aldeados e não aldeados, da região, como objeto de interesse principal. Nessa teia, partimos do fim da narrativa, que propositalmente tentou escamotear a presença dos índios e de Ferradas da história da região e, seguindo os vestígios documentais, foi surpreendente analisá-los atuando de forma central ao longo de todo o processo colonial.

O primeiro capítulo deste estudo, intitulado Nem tudo era sergipano: a escrita do mito pioneiro e a invisibilização indígena nas origens de Itabuna funcionou como antessala do texto e respondeu a várias questões formuladas 
nos primeiros semestres da graduação sobre os escritos memorialistas e as inquietações pela descoberta da existência de um aldeamento em Ferradas, no século XIX. A partir desse momento, surgiram as primeiras perguntas, que se multiplicaram ao longo da minha trajetória acadêmica; e delas tenho me ocupado até então. Retornar à discussão da escrita da memória, durante a realização do curso de mestrado, resultou de uma escolha estabelecida pelo amadurecimento com a pesquisa indígena e a necessidade de reforçar alguns argumentos empreendidos em outros momentos da pesquisa, bem como lançar novos argumentos sobre o problema da invisibilização indígena na escrita da memória de Itabuna. Também escolhi recuperar a escrita memorialista nestas páginas finais do texto, como uma tentativa de fechar esse ciclo de debate.

$\mathrm{O}$ trabalho indígena e sua contribuição na conformação social da região foram os principais eixos da dissertação. No desenvolvimento do estudo, apresentamos o discurso dos memorialistas que, na década de 1960, construíram a história de Itabuna com base na figura dos migrantes sergipanos, distanciando a fundação do município do aldeamento de Ferradas. Também discutimos com a historiografia que, por outros caminhos, realizou algo semelhante: minimizou a importância do trabalho indígena para a região do cacau, reafirmando que os índios, ao contrário dos escravos africanos, não se ocuparam muito com o trabalho das fazendas de cacau. Contrariando essa assertiva, atestamos, ao longo do nosso estudo, a participação dos índios como atores sociais das transformações históricas da região, com ênfase na observação do trabalho indígena na estrada que ligava as vilas Ilhéus e Conquista, bem como na lavoura do cacau.

Procuramos demonstrar a estreiteza das relações entre governo, religiosos e particulares, quando os assuntos 
eram os índios e o aldeamento de Ferradas. Uma das famílias mais ricas e poderosas da região sul da Bahia, desde os tempos coloniais, era a família Sá. Por meio das relações matrimoniais, a tradicional família Sá se desdobrou em vários ramos através dos seus descendentes, entre eles, os Adami ${ }^{1}$. Em início do século XX, a família Adami Sá respondia à alcunha de "adamistas", representavam as famílias tradicionais na política de Ilhéus, como tratamos no primeiro capítulo. As relações dos Sá com o aldeamento de Ferradas e com os frades responsáveis por administrar o trabalho dos índios aldeados eram muito próximas, na segunda metade do século XIX. Mostra disso é o registro no qual observamos o coronel Egídio de Sá na administração interina do aldeamento. Em nome dos índios de Ferradas, ele requereu ao Diretor Geral dos Índios um missionário para o aldeamento, pois com a saída do Frei Rainero de Ovada, o aldeamento estava abandonado e os índios solicitavam a presença de outro missionário ${ }^{2}$.

Como demonstramos em outro momento do texto, o Aldeamento São Pedro de Alcântara foi administrado pelos frades capuchinhos italianos, exceto quando a administração interina coube ao coronel Egídio de Sá, no final

1 Em seu estudo, André Rosa Ribeiro observa que o controle sobre os patrimônios das famílias tradicionais e escravocratas de Ilhéus, ao longo do século XIX, que envolvia os principais núcleos agrários da região, se dava por relações matrimoniais que eram estabelecidas por laços de parentesco e de vizinhança. Desse modo, "a vizinhança nos antigos distritos municipais era formada basicamente por parentes consanguíneos ou de afinidade, membros da família extensa Sá, cujo núcleo formou-se a partir dos seguintes sobrenomes: Sá Bittencourt e Câmara, Homem d' El-Rei, de origem mineira; Adami, Hohlenwerger e Lavigne, de origem europeia": RIBEIRO, André Luís Rosa. Família, poder e mito: o município de S. Jorge de Ilhéus (1880-1912). Ilhéus: Editus, 2001, p.34.

2 APEB; Seção Colonial e Provincial; Série Agricultura / índios; maço: 4612; 21 de maio de 1859. 
da década de 1850. Isso demonstra, dentre outros aspectos, o interesse da família Sá, uma das mais proeminentes no plantio do cacau no sul da Bahia, na permanência e no funcionamento dos aldeamentos na região. O que priorizamos frisar, ao final deste texto, portanto, é a trajetória das relações que envolviam índios, capuchinhos e particulares em Ferradas, porque isso nos dá condição para reafirmar, conclusivamente, a participação direta dos índios nas reconfigurações sociais e econômicas da região, contradizendo a ideia de ausência do trabalho deles na economia do cacau.

Portanto, diferentemente da ausência indígena na história daquela parte da região sul da Bahia, desenhada pela escrita tradicional, nós conseguimos demonstrar, ao longo deste trabalho, os índios agindo e interagindo em todo o processo da colonização oitocentista na região: atuaram ao lado dos colonizadores, pacificaram a região para a entrada de colonos, trabalharam intensamente na abertura e manutenção da estrada Ilhéus-Conquista, trabalharam na navegação e desobstrução dos rios, foram mão de obra importante na lavoura do cacau e também agiram em benefício próprio, em todo esse processo. As interações étnicas lhes impuseram o desafio de modificar-se, e eles foram capazes de construir novas possibilidades a partir da interação com os colonizadores, por diferentes meios e estratégias, fosse pela guerra ou por via da negociação.

O estudo sobre os índios no sul da Bahia está só começando; este trabalho faz parte de um esforço coletivo de inclusão dos índios na história da região. Há muito a se pesquisar, no sentido de compreender a dimensão do papel desempenhado pelos índios na história da colonização nos anos imperiais, no sul da Bahia. Ao longo dos capítulos, foi possível tecer importantes respostas às questões cotejadas no processo da pesquisa, no sentido de 
compreender as especificidades da atuação indigenista e indígena, naquela faixa do sul da Bahia, no importantíssimo contexto da ascensão da lavoura do cacau, que deflagrou novas configurações política, econômica e social, das quais, em lugar de sua invisibilidade, como parecia sugerir o discurso oficial de fins do XIX, e como engendrou o discurso oficial de 1960, observamos os índios participarem como atores diretos de todo aquele processo. Este panorama histórico é fundamental para compreendermos a história e historicidade dos índios do sul da Bahia. Entender suas trajetórias históricas, em grande medida, ilumina a compreensão dos processos atuais que envolvem as populações indígenas e suas demandas políticas e sociais.

Embora a pesquisa seja infindável e as inquietações e questões estejam claras, a escrita pede uma conclusão, portanto, este estudo chegou ao fim. As questões suscitadas durante o desenrolar da pesquisa foram inúmeras, e não podemos abordar todas em uma dissertação de mestrado. Muito há que se perguntar e problematizar acerca da trajetória dos índios do sul da Bahia, durante o Oitocentos. Mas elas ficam para um próximo estudo, como também para outros interessados, capazes de incluir novas abordagens, questões e fontes que deem conta da inclusão das populações indígenas na história do sul da Bahia. 


\section{ANEXOS}




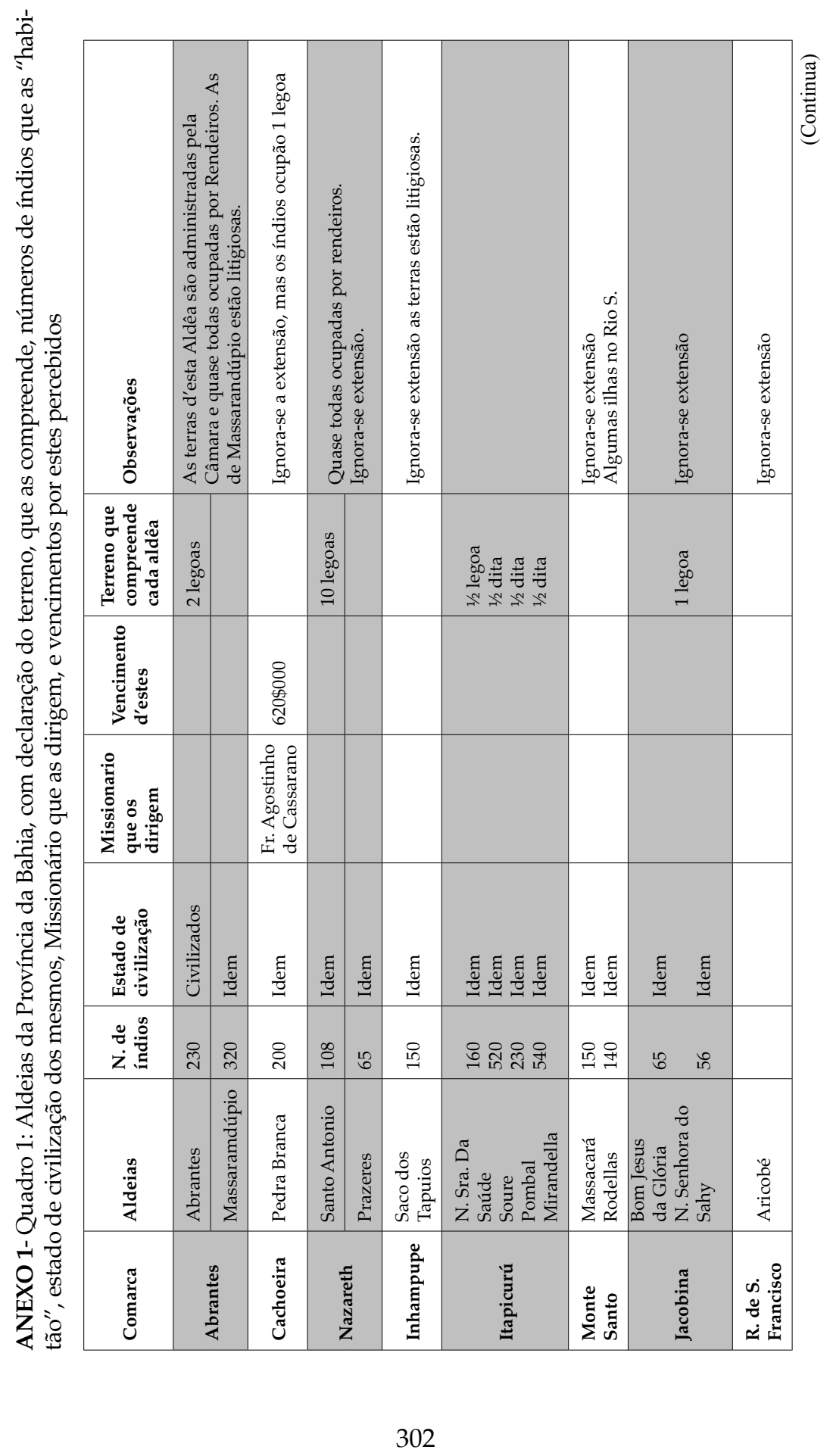




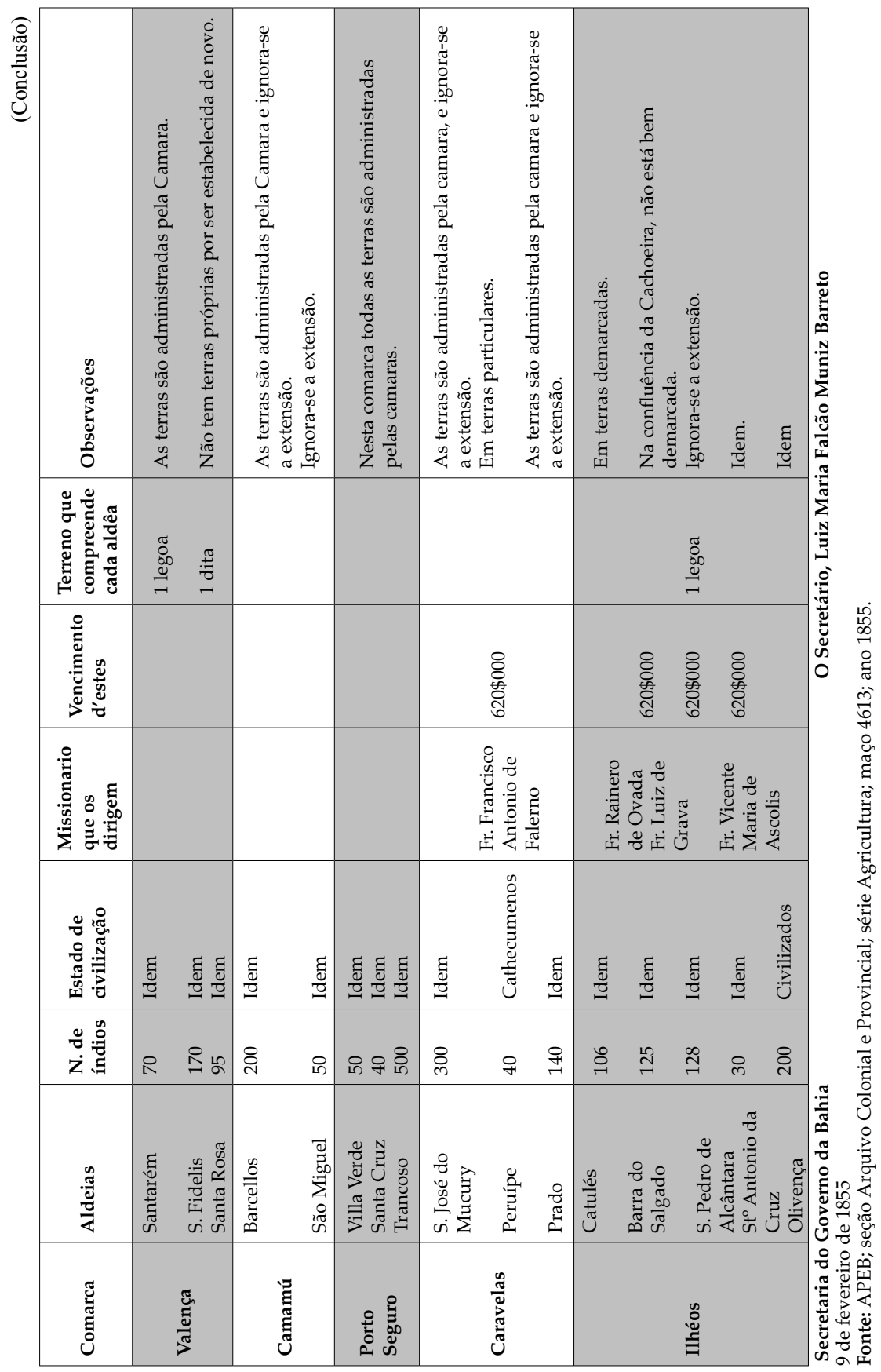




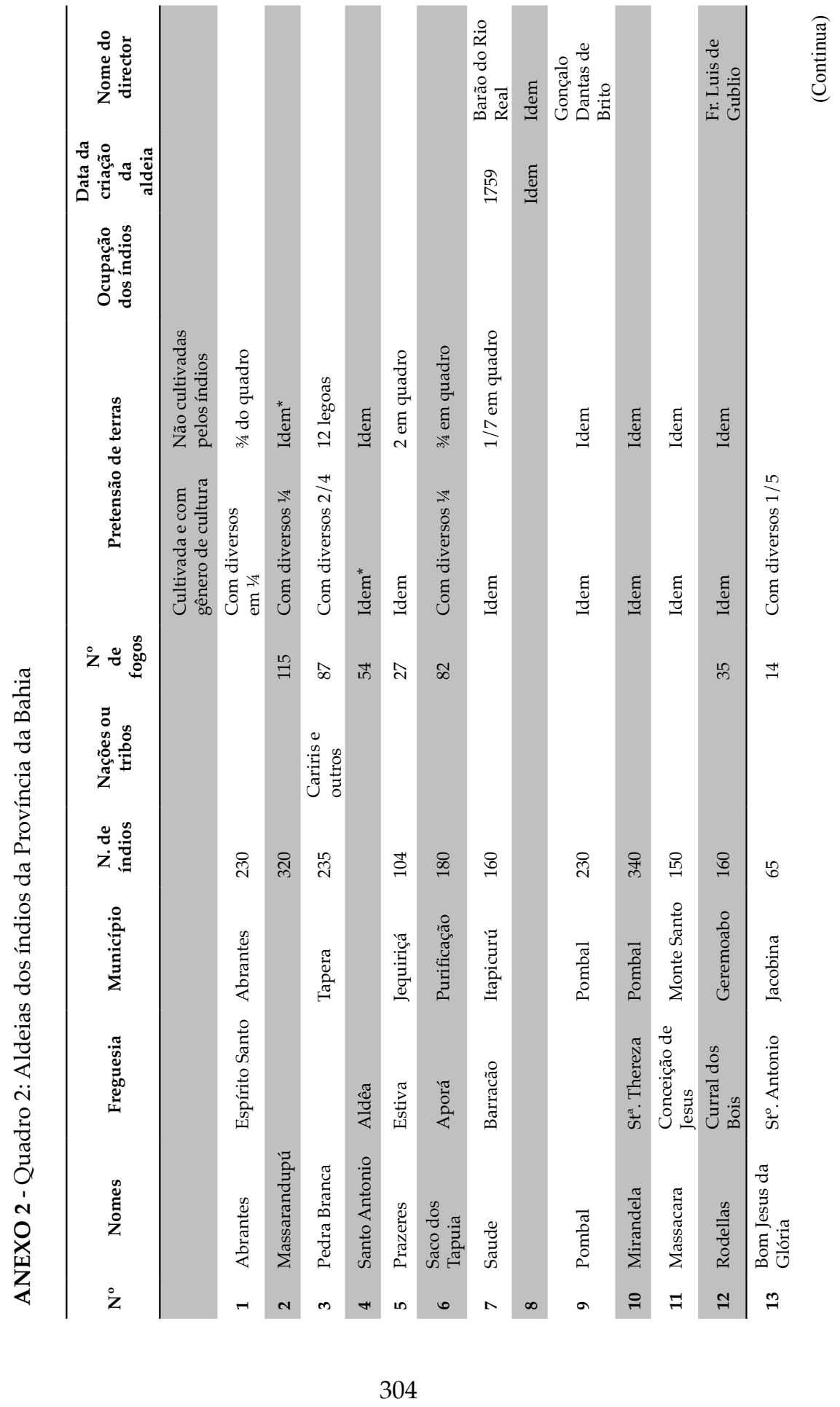




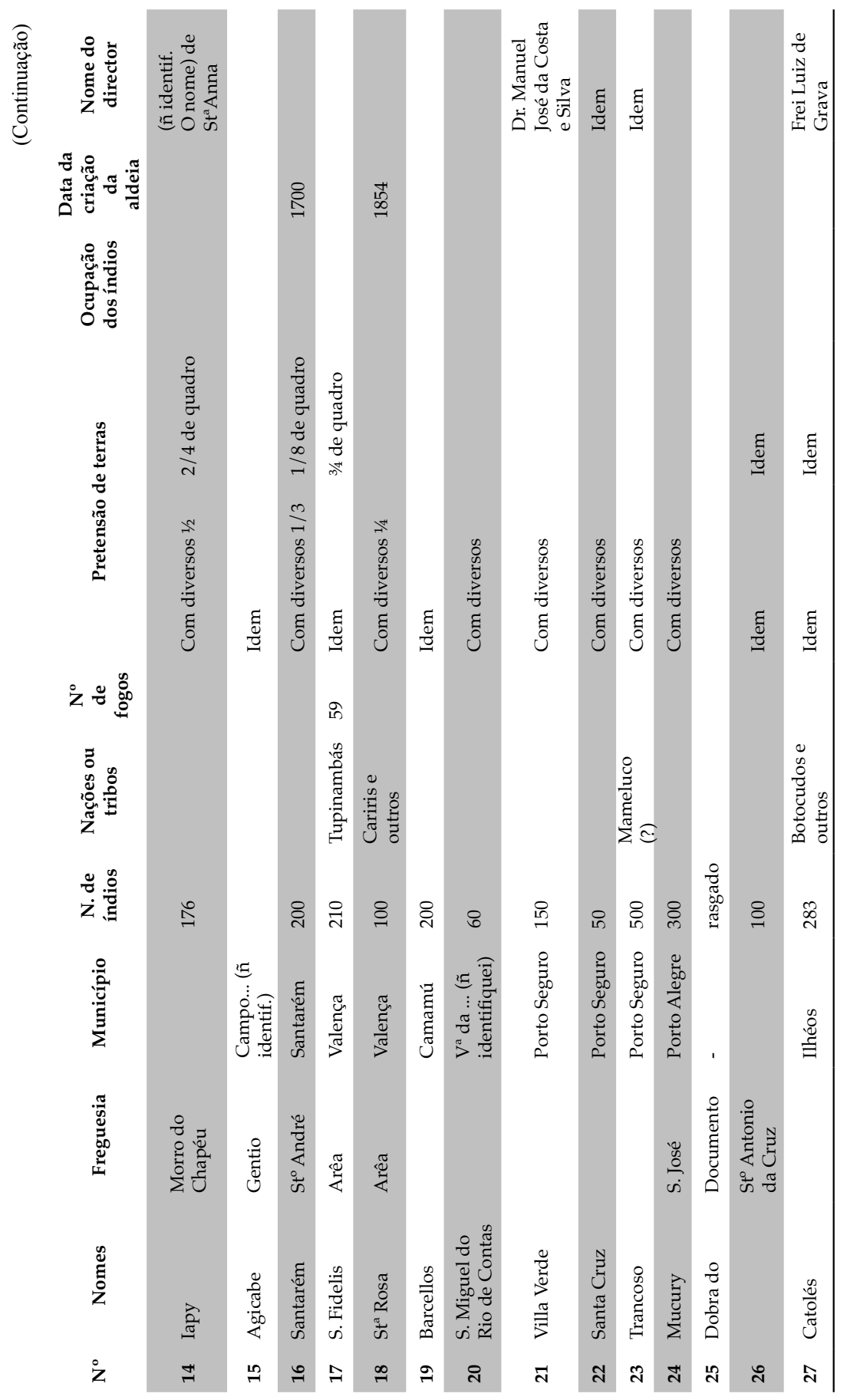




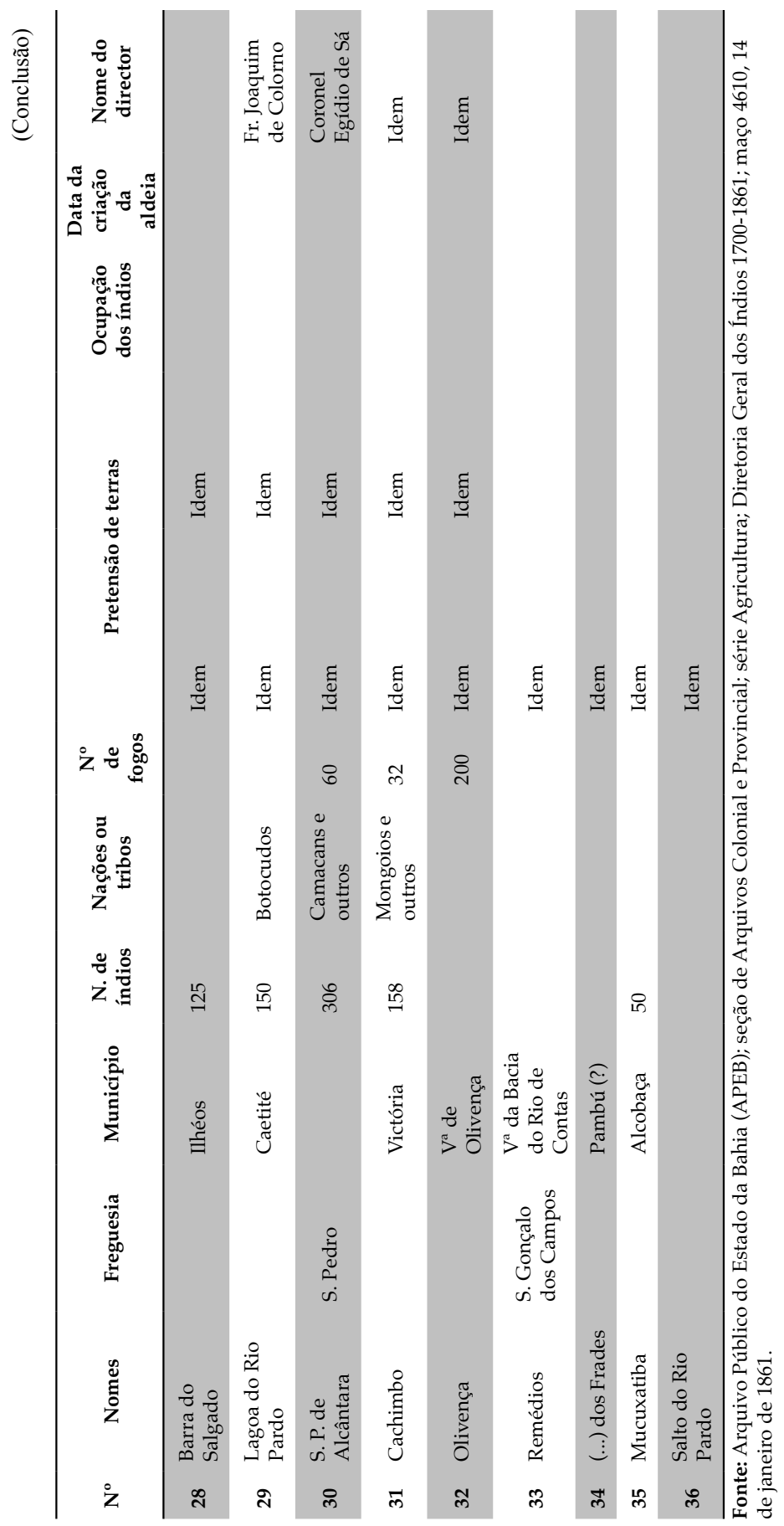


ANEXO 3 - Tabela 5: Assuntos tratados nas correspondências trocadas entre autoridades de Ilhéus e a presidência da Província da Bahia

\begin{tabular}{|c|c|}
\hline $\begin{array}{l}\text { ASSUNTO } \\
1826-1845\end{array}$ & FREQUÊNCIA \\
\hline Civilização & 1 \\
\hline Catequese & 4 \\
\hline Perseguição aos índios não aldeados & 2 \\
\hline Segurança do aldeamento & 14 \\
\hline Verba & 7 \\
\hline Ataque dos índios não aldeados ao aldeamento & 5 \\
\hline Ataque aos passageiros da estrada & 1 \\
\hline Fereza dos Botocudos & 3 \\
\hline Assassinato de aldeado pelos Botocudos & 1 \\
\hline Requerimento dos índios para aldearem-se & 3 \\
\hline Trabalho & 7 \\
\hline Demografia & 1 \\
\hline $\begin{array}{l}\text { ASSUNTO } \\
1848 \text { - } 1868\end{array}$ & FREQUÊNCIA \\
\hline Civilização & 3 \\
\hline Catequese & 1 \\
\hline Segurança do aldeamento & 2 \\
\hline Verba & 6 \\
\hline Ataque dos não aldeados ao aldeamento & 2 \\
\hline Trabalho & 18 \\
\hline Demografia & 1 \\
\hline Requerimento de terras pelos índios & 2 \\
\hline Solicitação de munição e roupas & 2 \\
\hline Solicitação de utensílios para atrair os índios & 1 \\
\hline Comércio & 1 \\
\hline Estado do aldeamento & 3 \\
\hline Deserção & 1 \\
\hline Novos aldeamentos & 5 \\
\hline
\end{tabular}

Fonte: Tabela construída a partir dos dados compulsados nas correspondências trocadas entre autoridades imperiais locais e provinciais. APEB; Seção Arquivo Colonial e Provincial, maços: 2396, 2395-I, 2397, 2401, 4611, 4612 e 4613. 


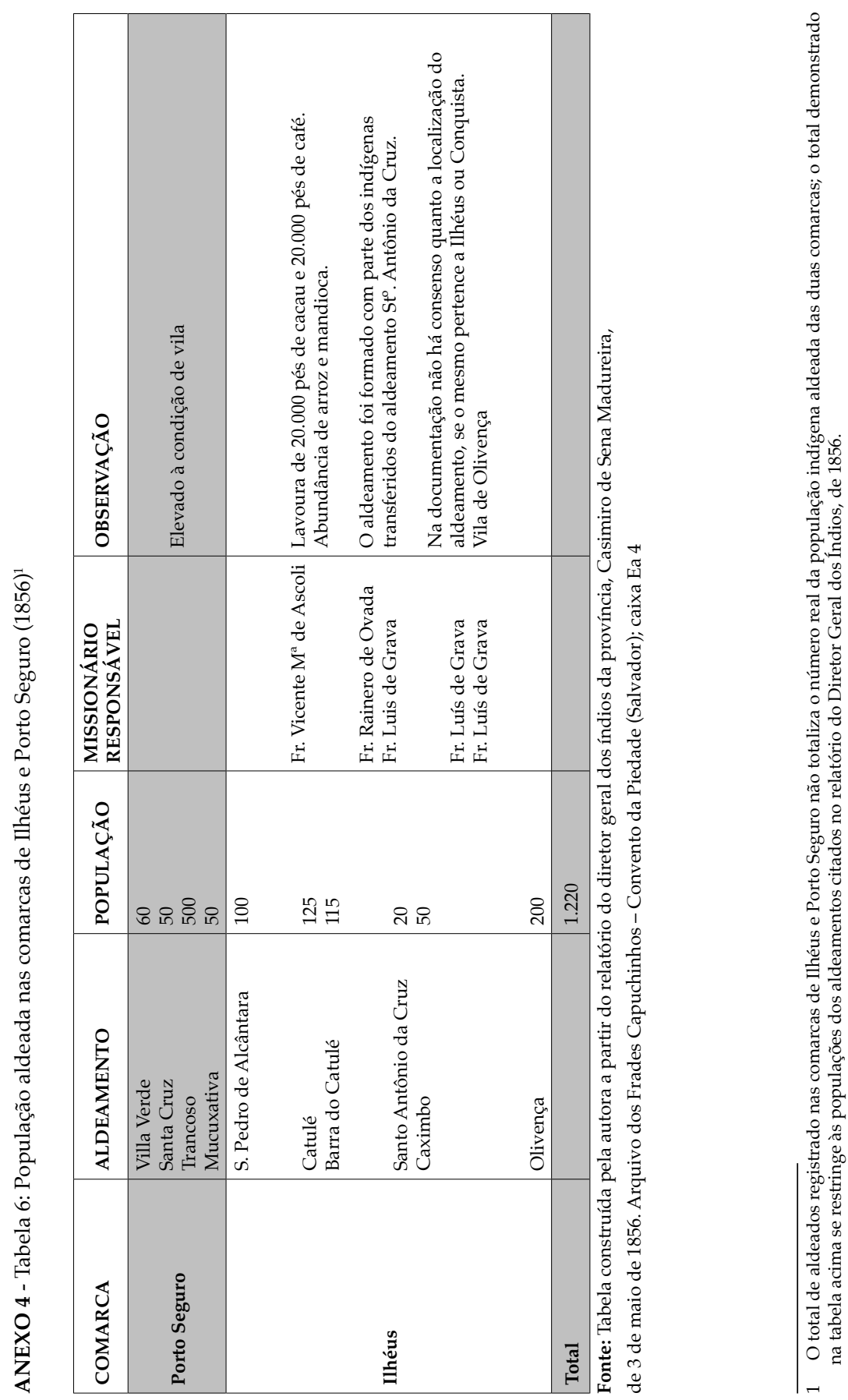




\section{REFERÊNCIAS}

ALMEIDA, Maria Regina Celestino de. Os índios na história do Brasil. Rio de Janeiro: Editora FGV, 2010.

. Metamorfoses indígenas: Identidade e cultura nas aldeias do Rio de Janeiro. 2. ed. Rio de Janeiro: Editora FGV, 2013.

AMOROSO, Marta Rosa. Catequese e evasão: etnografia do Aldeamento Indígena São Pedro de Alcântara, Paraná (18551895). Tese de doutorado. USP, 1998.

ANDRADE, João Cordeiro. Missões Capuchinhas na Comarca de São Jorge dos Ilhéus (1816-1875). Monografia. Ilhéus, UESC, 2003.

APOLINÁRIO, Juciene Ricarte. “Os Akroá nos sertões coloniais: uma história de guerra e "paz" entre currais e descobertos auríferos". In: OLIVEIRA, João Pacheco de (Org.). A presença indígena no Nordeste: processos de territorialização, modos de reconhecimento e regimes de memória. Rio de Janeiro: Contracapa, 2011.

BARTH, Frederik. "Grupos étnicos e suas fronteiras". In: POUTIGNAT, Philippe; STREIFF-FENART, Jocelyne. Teorias da etnicidade: seguido de grupos étnicos e suas fronteiras. 2. ed. São Paulo: Ed. UNESP, 2011.

BOCCARA, Guillaume. Poder colonial e etnicidade no Chile: territorialização e reestruturação entre os Mapuche da época colonial. Tempo: UFF, v. 12, n. 23, 2007. 
CAMPOS, João da Silva. Crônicas da Capitania de São Jorge dos Ilhéus. Rio de Janeiro: MEC-CFC, 2006.

CARVALHO, Maria Rosário de. “Índios do sul e extremo sul baianos: reprodução demográfica e relações interétnicas". In: OLOVEIRA, João Pacheco de (Org.). A presença indígena no Nordeste: processos de territorialização, modos de reconhecimento e regimes de memória. Rio de Janeiro: Contracapa, 2011.

CUNHA, Manuela Carneiro da. "Política indigenista no século XIX". In: CUNHA, Manuela Carneiro da (Org.). História dos índios no Brasil. São Paulo: FAPESP, Companhia das Letras, 1992.

DANTAS, Robson Norberto. Entre a arte, a história e a política: itinerários e representações da "ficção brasiliana" e da nação brasileira em Adonias Filho (1937-1976). Tese de doutorado. UNICAMP, Campinas: São Paulo, 2010.

DIAS, Marcelo Henrique. "A inserção econômica dos aldeamentos jesuíticos na capitania de Ilhéus”. In: CARRARA, Ângelo Alves; DIAS, Marcelo Henrique (Orgs.). Um lugar na história: a capitania e comarca de Ilhéus antes do cacau. Ilhéus: Editus, 2007.

. Economia, sociedade e paisagens da Capitania e Comarca de Ilhéus no período colonial. Tese de doutorado. UFF, Niterói-RJ: 2007.

ELIAS, Nobert. O processo civilizador: uma história dos costumes. V. 1. Rio de Janeiro: Ed. Jorge Zahar, 1994.

FERREIRA, Talita Almeida. Posto Indígena Paraguaçu: território de conflitos e resistências indígenas (1026-1936). Monografia de especialização. Universidade Estadual de Santa Cruz. Ilhéus-BA, 2012. 
FREITAS, Antônio Guerreiro de; PARAÍSO, Maria Hilda Baqueiro. Caminhos ao encontro do mundo: a capitania, os frutos de ouro e a Princesa do Sul- Ilhéus, 1534-1940. Ilhéus: Editus, 2001.

FOGUEIRA, Manoel Bonfim; GONÇALVES, Oscar Ribeiro. Ensaios históricos de Itabuna: O Jequitibá da Taboca, 19491960. Atualização, introdução e notas Janete Ruiz de Macedo e João Cordeiro de Andrade. 2. ed. revisada e ampliada. Ilhéus: Editus, 2011.

FOUCAULT, Michel. A ordem do discurso: aula inaugural no Collège de France, pronunciada em 2 de dezembro de 1970. 22. ed. São Paulo: Edições Loyola, 2012.

FULLER, Claudia Maria. Os corpos de trabalhadores e a organização do trabalho livre na província do Pará (18381859). Mundos do Trabalho. Florianópolis: GT Mundos do Trabalho/ Associação Nacional de História, v. 3, n. 6, 2011.

GINZBURG, Carlo. O fio e os rastros: verdadeiro, falso, fictício. São Paulo: Companhia das Letras, 2007.

GUIMARÃES, Manoel Luiz Salgado. "A disputa pelo passado na cultura histórica oitocentista no Brasil". In: CARVALHO, José Murilo de (Org.). Nação e cidadania no Império: novos horizontes. Civilização Brasileira, 2007.

. Historiografia e nação no Brasil: 1838-1857. Rio de Janeiro: EDUERJ, 2011.

HALBWACHS, Maurice. A memória coletiva. São Paulo: Centauro, 2003.

KODAMA, Kaori. Os índios no Império do Brasil: a etnologia do IHGB entre as décadas de 1840 e 1860. Rio de Janeiro: Editora FIOCRUZ; São Paulo: EDUSP, 2009. 
LE GOFF, Jacques. História e memória. 5. ed. Campinas: São Paulo, Editora da Unicamp, 2003.

LOPES, Fátima Martins. Em nome da liberdade: as vilas de índios do Rio Grande do Norte sob o Diretório Pombalino no século XVIII. Tese de doutorado. Universidade Federal de Pernambuco. Recife, 2005.

LUCAIOLI, Carina P.; NACUZZI, Lidia R. (Orgs.) Fronteras: Espacios de interacción en las tierras bajas del sur de América. Buenos Aires: Sociedad Argentina de Antropologia, 2010.

LYRA, Henrique Buckingham. "A 'crise' de mão de obra e a criação de colônias agrícolas na Bahia: 1850-1889”. In: DIAS, Marcelo Henrique; CARRARA, Ângelo Alves (orgs.). Um lugar na história: a capitania e comarca de Ilhéus antes do cacau. Ilhéus: Editus, 2007.

MACHADO, Marina Monteiro. A trajetória da destruição. Índios e terras no Império do Brasil. Dissertação. UFF, Niterói, 2006.

MAHONY, Mary Ann. The world cacao made: society, politics and history, in Southern Bahia, Brazil, 1822-1919. Dissertation of the degree of doctor of Philosophy. Yale University. Estados Unidos, 1996.

. "Instrumentos necessários": escravidão e posse de escravos no sul da Bahia no século XIX, 1822-1889. Afro-Ásia, n. 25-26. Universidade Federal da Bahia, 2001.

MAHONY. Um passado para justificar o presente: memória coletiva, representação histórica e dominação política na região cacaueira da Bahia. Especiaria, v. 10, n. 18, julho-dezembro. 2007. 
MALHEIROS, Márcia. "Homens da fronteira", indios e capuchinhos na ocupação dos sertões leste do Paraíba ou Goytacazes nos séculos XVIII e XIX. Tese de doutorado. Universidade Federal Fluminense, Niterói: Rio de Janeiro, 2008.

MAMIGONIAN, Beatriz G.; POPINIGIS, Fabiane. Dossiê (Outros) Trabalhadores livres no Atlântico oitocentista. Mundos do Trabalho. Florianópolis: GT Mundos do Trabalho/Associação Nacional de História, v. 3, n. 6, 2011.

MAMIGONIAN, Beatriz G. Em nome da liberdade: abolição do tráfico de escravos, o direito e o ramo brasileiro do recrutamento de africanos (Brasil-Caribe britânico, 1830-1850). Mundos do Trabalho. Florianópolis: GT Mundos do Trabalho/Associação Nacional de História, v. 3, n. 6, 2011.

MARCIS, Teresinha. A integração dos índios como súditos do rei de Portugal: uma análise do projeto, dos autores e da implantação na Capitania de Ilhéus, 1758-1822. Tese de doutorado. Universidade Federal da Bahia. Salvador, 2013.

MATTOS, Izabel Missagia de. Civilização e revolta: os Botocudos e a catequese na Província de Minas. Bauru, SP: EDUSC, 2004.

MONTEIRO, John Manuel. Negros da terra: índios e bandeirantes nas origens de São Paulo. São Paulo: Companhia da Letras, 1994.

. Tupis, Tapuias e historiadores: estudos de história indígena e do Indigenismo. Tese de livre docência. Campinas: Unicamp, 2001.

MOREIRA NETO, Carlos de Araújo. Os índios e a ordem imperial. Brasília: CGDOC-FUNAI, 2005.

MOREIRA, Vânia Maria Losada. A serviço do Império e da nação: trabalho indígena e fronteiras étnicas no Espírito Santo (1822-1860). Anos 90, Porto Alegre, v. 17, n. 31, 2010. 
MOREIRA, "1808: a guerra contra os botocudos e a recomposição do Império Português nos trópicos". In: CARDOSO, José Luís; MONTEIRO, Nuno Gonçalo e SERRÃO, José Vicente (Orgs.).

Portugal, Brasil e a Europa napoleónica. Lisboa: ICS. Imprensa de Ciências Sociais, 2010.

. O ofício do historiador e os índios: sobre uma querela no Império. Revista Brasileira de História. São Paulo, v. 30, n. 59, 2010.

. Entre as vilas e os sertões: trânsitos indígenas e transculturações nas fronteiras do Espírito Santo (1798-1840). Nuevo Mundo Mundos Nuevos. Debates, 2011.

. “Nós índios, índios nós senhores de nossas ações... Direito de domínio dos índios e cristandade em conflito (Vila de Nova Benavente, Capitania do Espírito Santo, 1795-1798)"'. In: MOTTA, Márcia; SERRÃO, José Vicente e MACHADO, Marina (Orgs.). Em terras lusas: conflitos e fronteiras no Império Português. Vinhedo. Editora Horizonte, 2013.

MOTTA, Márcia Menendes. Nas fronteiras do poder: conflito e direito à terra no Brasil do século XIX. 2. ed. Rio de Janeiro: EDUFF, 2008.

MUÑOZ, Laura. “Bajo el cielo ardiente de los trópicos: las fronteras del Caribe em el siglo XIX". In: GUTIÉRREZ, Horácio; NAXARA, Márcia R. C. e LOPES, Maria Aparecida de S. (Orgs.). Fronteiras: Paisagens, personagens, identidades. Franca: ENESP, São Paulo: Olho d'Água, 2003.

NACUZZI, Lidia R. Introdução. In: LUCAIOLI, Carina P.; NACUZZI, Lidia R. (Orgs.). Fronteras: espacios de interacción en las tierras bajas del sur de América. Buenos Aires: Sociedad Argentina de Antropologia, 2010.

OLIVEIRA, João Pacheco de. Uma etnologia dos "índios misturados"? Situação colonial, territorialização e fluxos culturais. Mana. Rio de Janeiro, v. 4, n. 1, p. 47-77. 1998. 
PARAÍSO, Maria Hilda Baqueiro. “Os Botocudos e sua trajetória histórica". In: CUNHA, Manuela Carneiro da (Org.). História dos índios no Brasil. São Paulo: FAPESP, Companhia das Letras, 1992.

. O tempo da dor e do trabalho: a conquista dos territórios indígenas nos sertões do leste. Tese de doutorado. USP. São Paulo, 1998.

PERRONE-MOISÉS, Beatriz. "Indios livres e índios escravos: os princípios da legislação do período colonial (séculos XVI a XVIII)". In: CUNHA, Manuela Carneiro da (Org.). História dos índios no Brasil. São Paulo: Companhia das Letras, FAPESP, 1992.

PESAVENTO, Sandra Jatahy. História e história cultural. 3. ed. Belo Horizonte: Autêntica, 2012.

PORTELLI, Alessandro. “O massacre de Civitella Val di Chiana (Toscana, 29 de junho de 1944): mito e política, luto e senso comum". In: AMADO, Janaína; FERREIRA, Marieta de Moraes (Orgs.). Usos e abusos da história oral. 8. ed. Rio de Janeiro: FGV, 2006.

PRATT, Mary Louise. Os olhos do Império: relatos de viagem e transculturação. Bauru, São Paulo: EDUSC, 1999.

REGNI, Pietro Vittorino. Os capuchinhos na Bahia: uma contribuição para a história da Igreja no Brasil. v. 2. Editora Palloti, 1988.

RIBEIRO, André Luís Rosa. Família, poder e mito: o município de S. Jorge de Ilhéus (1880-1912). Ilhéus: Editus, 2001.

RIBEIRO, Danilo Ornelas. Do fazer jornalístico às sociabilidades de elites: a construção da Itabuna moderna (1957-1964). Monografia. Universidade Estadual de Santa Cruz: Ilhéus, 2010.

RICOEUR, Paul. A memória, a história, o esquecimento. Campinas, São Paulo: Editora da Unicamp, 2007.

ROCHA, Lurdes Bertol. O centro da cidade de Itabuna: trajetórias, signos e significados. Ilhéus: Editus, 2003. 
SAMPAIO, Patrícia Melo. "Política indigenista no Brasil imperial". In: GRINBERG, Keila; SALLES, Ricardo (Orgs.). O Brasil imperial, volume I: 1808-1831. Rio de Janeiro: Civilização Brasileira, 2009.

. Espelhos partidos: etnia, legislação e desigualdade na Colônia. Manaus: Editora da Universidade Federal do Amazonas, 2011.

SCHWRTZ, Stuart B. Segredos internos: engenhos e escravos na sociedade colonial, 1550-1835. Tradução Laura Teixeira Motta. São Paulo: Companhia da Letras, 1988.

SILVA, Lígia Osório. Terras devolutas e latifúndios: efeito da Lei de 1850. Campinas: Editora da UNICAMP, 1996.

SILVEIRA, Adelino Kfoury. Itabuna, minha terra. Itabuna: Gráfica Santa Helena, 2002.

SOUZA, Telma Moreira de. Entre a cruz e o trabalho: a exploração da mão de obra indígena no sul da Bahia (1845-1875). Dissertação de mestrado. UFBA, 2007.

VARNHAGEN, Francisco Adolpho. "Discurso preliminar: os índios perante a nacionalidade brazileira". In: Os Índios e a ordem Imperial. MOREIRA NETO, Carlos Araújo. Brasília: Funai, 2005 [1852].

\section{FONTES MANUSCRITAS}

\section{ARQUIVO PÚBLICO DO ESTADO DA BAHIA}

APEB. Arquivo Colonial e Provincial. Seção Judiciário. Maços: 2395, 2395-I, 2396, 2397, 2401, 4610, 4611, 4612, 4613.

APEB. Seção Judiciário. Livros de Notas da Vila de Ilhéus: 5, 6, $11,12,13,14,15,16,20,21$. 
AN-RJ. Códice: 807, volume: 2, data: 1824.

ARQUIVO HISTÓRICO NOSSA SENHORA DA PIEDADE: ORDEM DOS FRADES MENORES CAPUCHINOS-SALVA$\mathrm{DOR} / \mathrm{BA}$

OFMCap-BA. Caixa Ea-2, Missões, data: 1926.

\section{FONTES PUBLICADAS}

Arquivo Center for Research Libraries. Disponível em:

$<$ http:/ / www.crl.edu/brazil/ provincial/bahia $>$. Relatórios Provinciais Presidenciais (1830-1930):

Fala do Presidente da Província da Bahia, João Maurício Wanderley, $1^{\circ}$ de março de 1853.

Fala do Presidente da Província da Bahia, $1^{\circ}$ de abril de 1860.

Fala do Presidente da Província da Bahia, Antônio da Costa pinto, $1^{\circ}$ de março de 1861.

Relatório do Presidente da Província da Bahia, 1869.

Relatório do Presidente da Província da Bahia, Francisco Gonçalves Martins, 1870.

Fala do Presidente da Província da Bahia na abertura da Assembléia Legislativa, $1^{\circ}$ de março de 1872.

Fala do Presidente da Província da Bahia, Antônio Cândido da Cruz Machado, $1^{\circ}$ de março de 1874.

Relatório do Presidente da Província da Bahia, Venâncio José de Oliveira Lisboa, $1^{\circ}$ de março de 1875. 


\section{FONTES HEMEROGRÁFICAS}

\section{CENTRO DE DOCUMENTAÇÃO E MEMÓRIA}

CEDOC-UESC. Diário de Itabuna, ano III, nº 698, data: 1960.

CEDOC-UESC. Diário de Itabuna, ano III, nº 730, data: 1960.

CEDOC-UESC. Diário de Itabuna, ano III, nº 739, data: 1960.

CEDOC-UESC. Diário de Itabuna, ano III, nº 730, data: 1960.

CEDOC-UESC. O Crepúsculo, edição n ${ }^{\circ}$ 13, data: 1846: Documentação sob a custódia da Universidade Federal da Bahia, campus de São Lázaro, Salvador-BA; cópia disponível no CEDOC-UESC.

\section{FONTES IMPRESSAS}

ANDRADE, José Dantas de. Documentário Histórico Ilustrado de Itabuna. Itabuna: Gráfica Editora Itabuna, 1968.

FREIRE, José Alves de Souza. Firmino Alves: Fundador de Itabuna. Itabuna: Edições ITAGRAF, 1963.

GONÇALVES, Oscar Ribeiro. O jequitibá da Taboca: ensaios Históricos de Itabuna, 1849-1960. Itabuna: Oficinas Gráficas da Imprensa da Bahia, 1960.

LISBOA, Balthazar da Silva. Annaes do Rio de Janeiro. Editora Leitura: Rio de Janeiro. Tomo VI. 1835.

PEREIRA FILHO, Carlos. Terras de Itabuna. Rio de Janeiro: Elos, 1960. 


\section{WEB - SITES CONSULTADOS}

Biblioteca Nacional Digital. Disponível em: $<$ http:/ / bndigital. bn,br/acervo_digital>.

Associação Transparência Municipal: Disponível: $<$ http:/ / www.ba.portaldatransparencia.com.br>. 


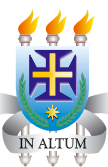

IMPRENSA UNIVERSITÁRIA

Impresso na gráfica da Universidade Estadual de Santa CruZ - Ilhéus-BA 